\title{
MORFOGÊNESE, DINÂMICA DO PERFILHAMENTO E DO ACÚMULO DE FORRAGEM EM PASTOS DE CAPIM-MARANDU SOB LOTAÇÃO CONTÍNUA
}

\author{
ANDRÉ FISCHER SBRISSIA
}

Tese apresentada à Escola Superior de Agricultura

“Luiz de Queiroz", Universidade de São Paulo, para obtenção do título de Doutor em Agronomia, Área de Concentração: Ciência Animal e Pastagens.

P I R A C I C A B A

Estado de São Paulo - Brasil

Março - 2004 


\title{
MORFOGÊNESE, DINÂMICA DO PERFILHAMENTO E DO ACÚMULO DE FORRAGEM EM PASTOS DE CAPIM-MARANDU SOB LOTAÇÃO CONTÍNUA
}

\author{
ANDRÉ FISCHER SBRISSIA \\ Engenheiro Agrônomo \\ Orientador: Prof. Dr. SILA CARNEIRO DA SILVA \\ Tese apresentada à Escola Superior de Agricultura \\ “Luiz de Queiroz”, Universidade de São Paulo, para \\ obtenção do título de Doutor em Agronomia, Área de \\ Concentração: Ciência Animal e Pastagens.
}

P I R A C I C A B A

Estado de São Paulo - Brasil

Março - 2004 


\section{Dados Internacionais de Catalogação na Publicação (CIP) DIVISÃO DE BIBLIOTECA E DOCUMENTAÇÃO - ESALQ/USP}

\section{Sbrissia, André Fischer}

Morfogênese, dinâmica do perfilhamento e do acúmulo de forragem em pastos de capim-Marandu sob lotação contínua / André Fischer Sbrissia. - - Piracicaba, 2004.

171 p. : il.

Tese (doutorado) - Escola Superior de Agricultura Luiz de Queiroz, 2004.

Bibliografia.

1. Capim Marandu 2. Forragem 3. Morfogênese vegetal 4. Pastagem 5. Perfilhação I. Título

CDD 633.2

"Permitida a cópia total ou parcial deste documento, desde que citada a fonte- 0 autor" 
"Preciso me perder, como preciso de ar. Perder o rumo é bom, se perdido a gente encontra um sentido escondido em algum lugar".

(Humberto Gessinger)

“... Continuar a crer, e a confiar, no grande amor que Tens, Meu Pai por mim. O meu desejo eterno é Te adorar, e aos Teus pés se derramar sem fim".

(Adaptado do Livro de Jó) 


\section{DEDICO}

Aos meus pais, Luiz Carlos e Ursula.

\section{MINHA GRATIDÃO}

\section{OFEREÇO}

À minha namorada Elaine Cristina

Aos meus irmãos Gustavo e Larissa 


\section{AGRADECIMENTOS}

À Deus, acima de tudo.

À USP/Esalq pela oportunidade de realização desse Curso.

Ao Professor Dr. Sila Carneiro da Silva pela orientação inestimáve 1, confiança e pelo exemplo de conduta profissional.

À Massey University, Nova Zelândia, pela oportunidade de estágio e, em especial, ao Dr. Cory Matthew e Professor John Hodgson, pelos valiosos comentários e ensinamentos e pela ajuda durante a minha perma nência naquele País.

Aos grandes amigos e companheiros de trabalho, Adriano Lupinacci, Alexandre Gonçalves, Daniel Sarmento, Flávia de Andrade e Leonardo Molan, pela convivência harmoniosa, nem sempre serena, aprendizado e pela dedicação inarrável ao projeto.

A todos os professores do Departamento de Zootecnia.

A todos os estagiários do GEPF, pela confiança na idéia e pela ajuda incalculável que possibilitou a realização desse trabalho

Aos colegas do curso de pós-graduação pelo incentivo e amizade.

Aos amigos, Mauro, Humberto, Frederico e Ary, com quem dividi moradia durante boa parte de minha permanência em Piracicaba.

Ao Stuart e Daniela pela inesquecível ajuda durante minha permanência na Nova Zelândia.

A todos os funcionários do Departamento de Zootecnia pela cooperação e amizade. 
Aos meus pais, pela entrega absoluta e incondicional na minha formação.

À minha querida Elaine, pela paciência, ajuda, compreensão e incentivo.

Aos meus irmãos Gustavo e Larissa, pelas conversas, incentivos e apoio.

À Fundação de Amparo à Pesquisa do Estado de São Paulo (FAPESP), pela concessão da bolsa de estudo.

A todos que contribuíram direta ou indiretamente para a realização deste trabalho. 


\section{SUMÁRIO}

Página

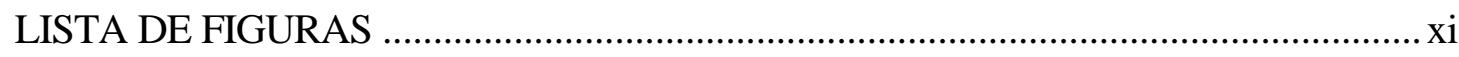

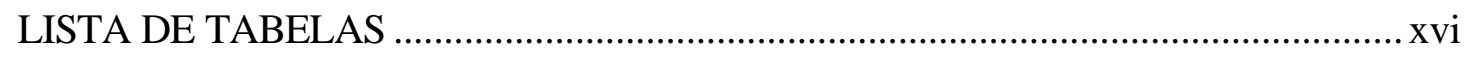

LISTA DE ABREVIATURAS E SÍMBOLOS......................................................... xxii

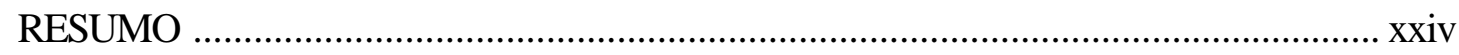

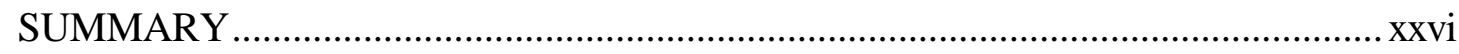

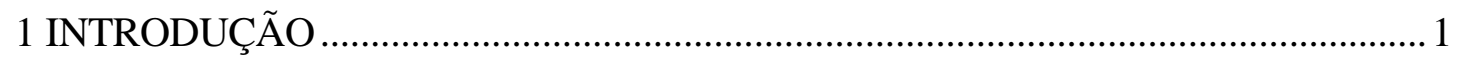

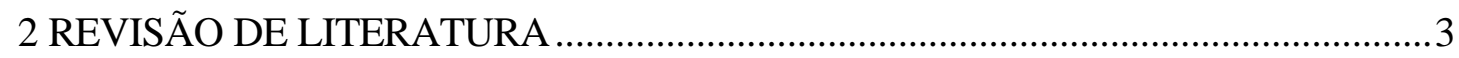

2.1 Perfilho: a unidade básica de gramíneas ...................................................................... 3

2.2 Morfogênese de plantas forrageiras e estrutura do relvado.........................................4

$2.3 \mathrm{O}$ processo de acúmulo de forragem em pastagens................................................... 6

2.4 Comunidade de plantas forrageiras - populações de perfilhos .....................................

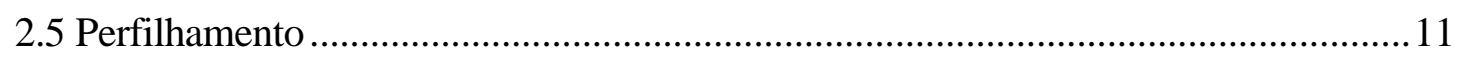

2.6 Compensação tamanho/densidade populacional de perfilhos em pastagens ..............12

2.7 Variações estacionais em densidade populacional de perfilhos................................... 16

2.8 Manipulação da estacionalidade da demografia populacional de perfilhos para fins

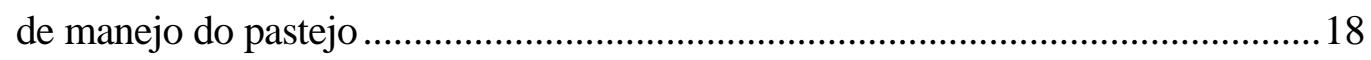

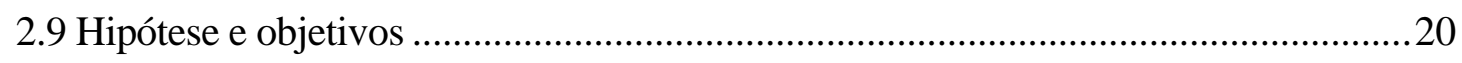

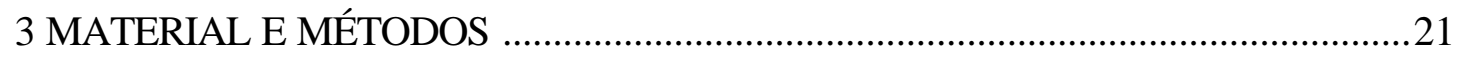

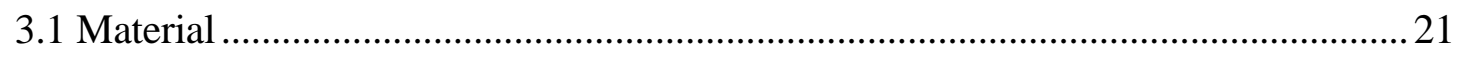

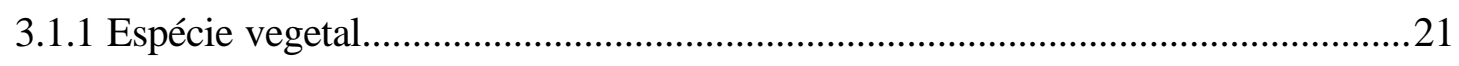

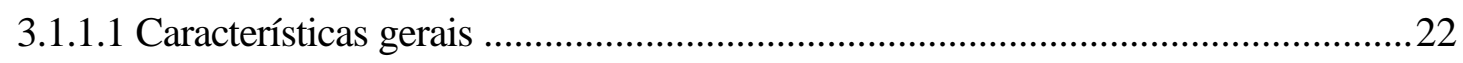




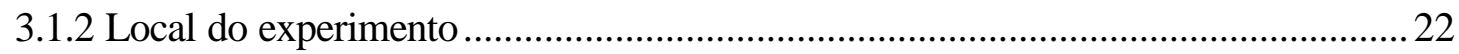

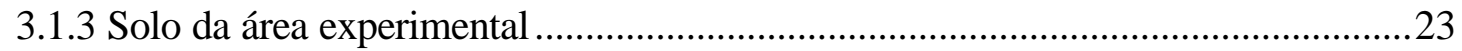

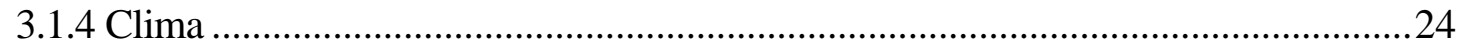

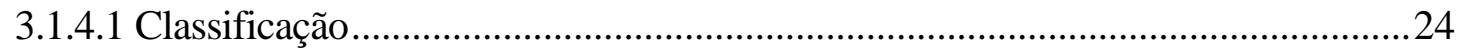

3.1.4.2 Dados climáticos durante o período experimental ..............................................25

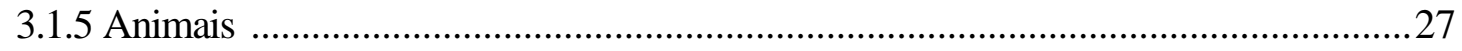

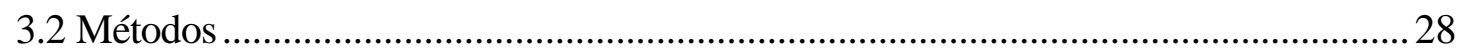

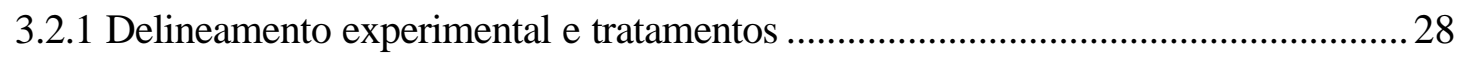

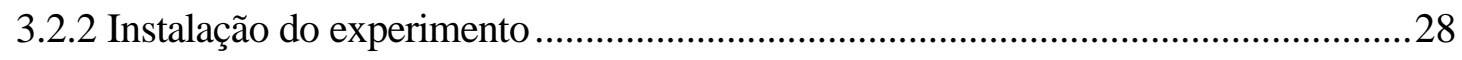

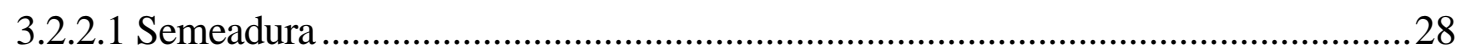

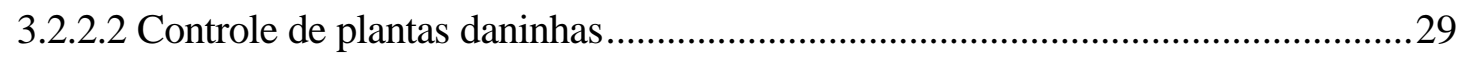

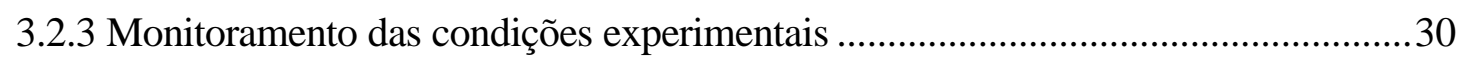

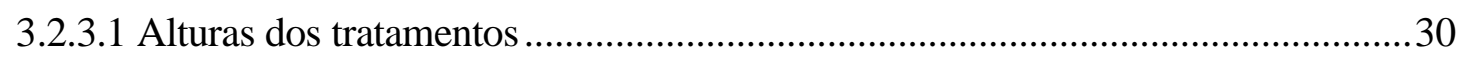

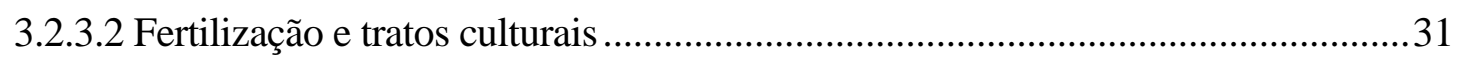

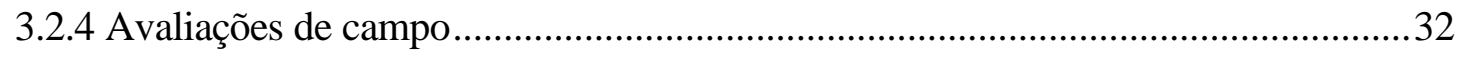

3.2.4.1 Morfogênese e dinâmica do acúmulo de massa seca .............................................32

3.2.4.1.1 Medições realizadas nos perfilhos.................................................................... 34

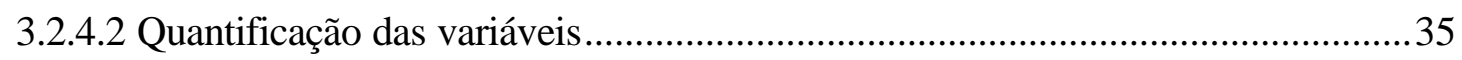

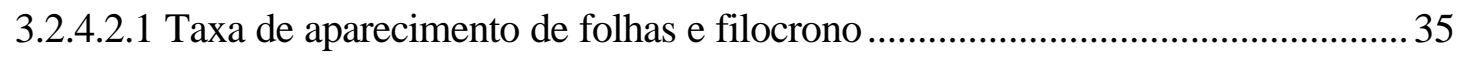

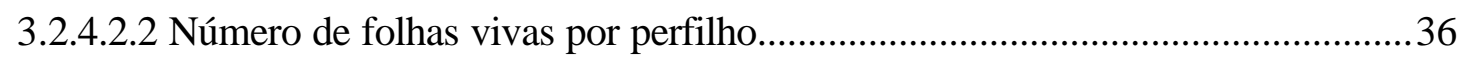

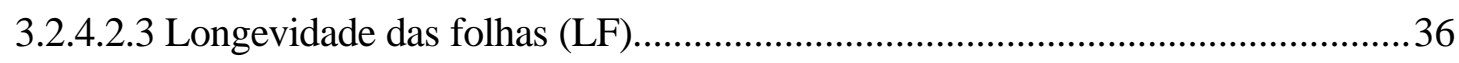

3.2.4.2.4 Taxas de crescimento, senescência e acúmulo líquido ......................................36

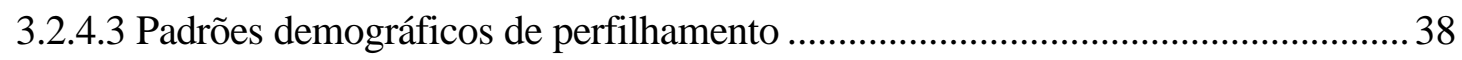

3.2.4.3.1 Taxas de aparecimento, mortalidade e sobrevivência de perfilhos ....................41

3.2.4.3.2 Densidade populacional de perfilhos .................................................................41

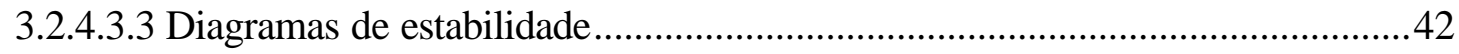

3.2.4.4 Avaliações de características individuais dos perfilhos ......................................42

3.2.4.4.1 Massa de folhas, massa média e área foliar média por perfilho..........................43

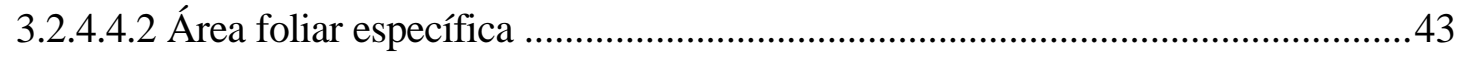

3.2.4.4.3 Relação folha: haste e razão área foliar: volume por perfilho $(\mathrm{R})$.....................43 


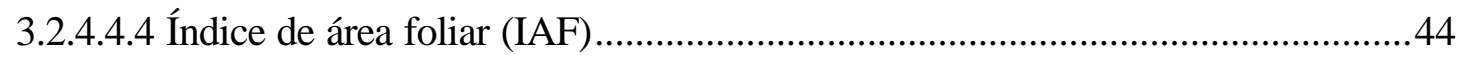

3.2.4.4.5 Volume $\left(\mathrm{m}^{3}\right)$ e densidade aparente média $\left(\mathrm{kg}\right.$ massa verde. $\left.\mathrm{m}^{-3}\right)$...................... 45

3.2.5 Processamento dos dados e análise estatística .....................................................47

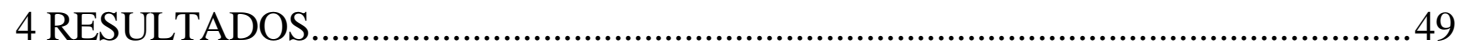

4.1 Características morfogênicas ................................................................................. 49

4.1.1 Número de folhas em expansão, senescentes e vivas por perfilho ...........................49

4.1.2 Comprimento médio de folhas intactas e da haste ...................................................58

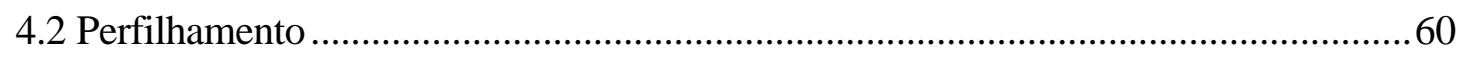

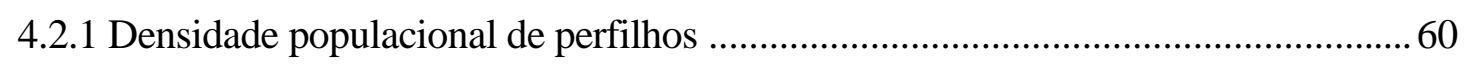

4.2.2 Proporção de perfilhos com inflorescência visível ................................................62

4.2.3 Taxas de aparecimento, sobrevivência e mortalidade de perfilhos ..........................63

4.2.4 Padrões demográficos do perfilhamento e diagramas de estabilidade.....................67

4.3 Características de perfilhos individuais .................................................................... 75

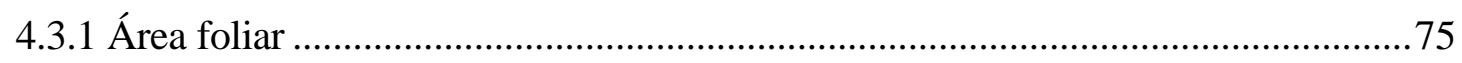

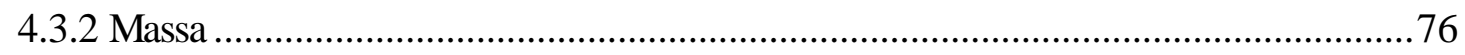

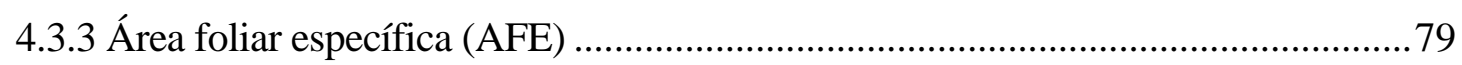

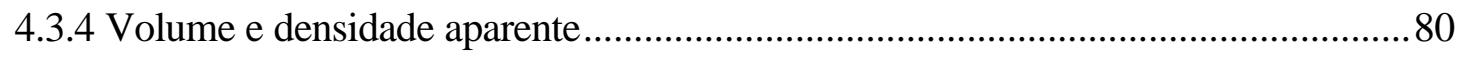

4.3.5 Relação folha: haste e razão área foliar: volume (R) .......................................... 82

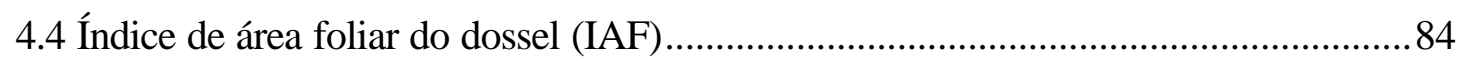

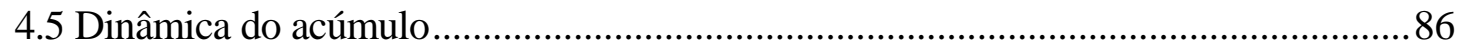

4.5.1 Taxas de alongamento, senescência e remoção de folhas ........................................86

4.5.2 Taxas de crescimento, senescência, remoção e acúmulo líquido de forragem do

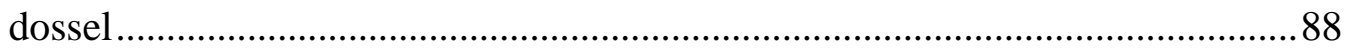

4.6 Compensação tamanho/densidade populacional de perfilhos ...................................100

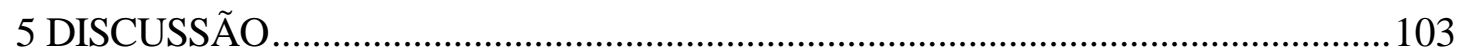

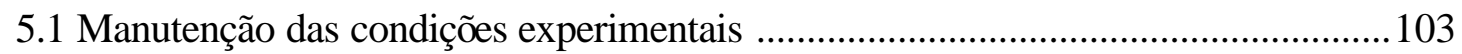

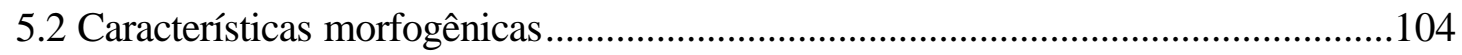

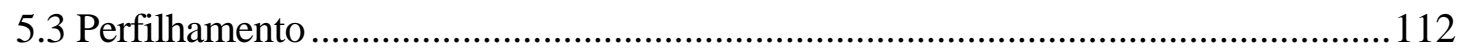

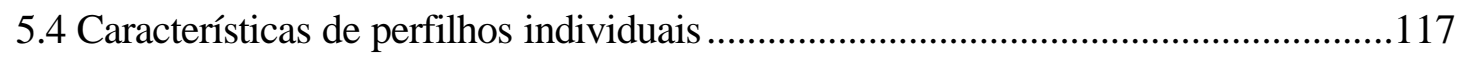

5.4.1 Metodologia para mensuração de volume de perfilhos........................................120 


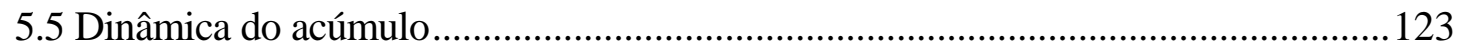

5.6 Compensação tamanho/densidade populacional de perfilhos ...................................129

5.6.1 Relação funcional entre massa e densidade populacional de perfilhos..................129

5.6.2 Implicações agronômicas ...................................................................................... 135

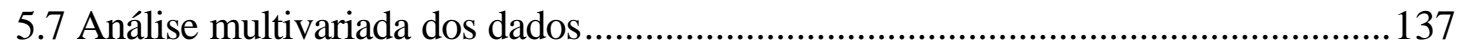

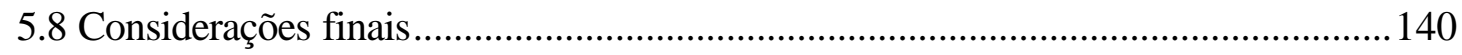

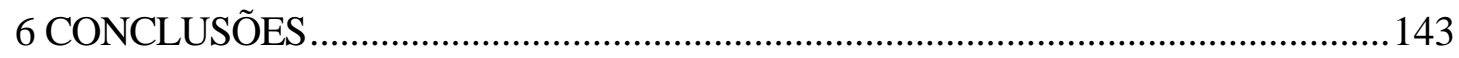

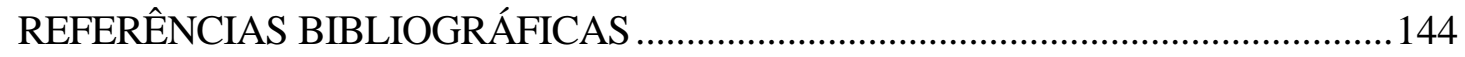

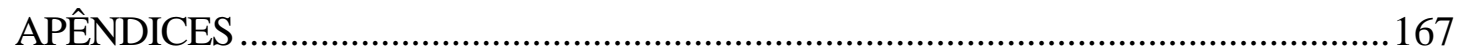




\section{LISTA DE FIGURAS}

Página

1 Vista geral da área experimental 23

2 Temperaturas médias mensais durante o período experimental comparada com a média dos últimos 85 anos (1917-2002) 25

3 Totais mensais da precipitação durante o período experimental comparada com a média dos últimos 85 anos (1917-2002) 26

4 Distribuição da insolação média durante o período experimental comparada com a média dos últimos 85 anos (1917-2002) .26

5 Extrato do balanço hídrico dos decêndios mensais do período de novembro de 2001 a dezembro de $2002(\mathrm{CAD}=50 \mathrm{~mm})$ e épocas de adubação nitrogenada.. 27

6 Valores médios das alturas dos tratamentos ao longo do período experiment al......31

7 Estacas para delimitação das réguas transectas 33

8 Detalhe da marcação dos perfilhos. 33

9 Detalhe do anel de PVC usado na marcação dos perfilhos e dos grampos fixadores 
10 Detalhe da marcação de perfilhos em dosséis de $40 \mathrm{~cm}$ 40

11 Detalhe da marcação de perfilhos em dosséis de $10 \mathrm{~cm}$ 40

12 Detalhe do equipamento utilizado para medições de volume 46

13 Densidade populacional de perfilhos em pastos de capim-Marandu mantidos a 10, 20, 30 e $40 \mathrm{~cm}$ de altura por bovinos de corte em lotação contínua em diferentes épocas do ano 61

14 Taxas de aparecimento e mortalidade de perfilhos em pastos de capim-Marandu mantidos a $10 \mathrm{~cm}$ de altura por bovinos em lotação contínua 64

15 Taxas de aparecimento e mortalidade de perfilhos em pastos de capim-Marandu mantidos a $20 \mathrm{~cm}$ de altura por bovinos em lotação contínua 65

16 Taxas de aparecimento e mortalidade de perfilhos em pastos de capim-Marandu mantidos a $30 \mathrm{~cm}$ de altura por bovinos em lotação contínua 65

17 Taxas de aparecimento e mortalidade de perfilhos em pastos de capim-Marandu mantidos a $40 \mathrm{~cm}$ de altura por bovinos em lotação contínua .66

18 Padrão demográfico do perfilhamento em pastos de capim-Marandu mantidos a 10 $\mathrm{cm}$ de altura do dossel forrageiro por bovinos em lotação contínua .68

19 Padrão demográfico do perfilhamento em pastos de capim-Marandu mantidos a 20 $\mathrm{cm}$ de altura do dossel forrageiro por bovinos em lotação contínua 69

20 Padrão demográfico do perfilhamento em pastos de capim-Marandu mantidos a 30 $\mathrm{cm}$ de altura do dossel forrageiro por bovinos em lotação contínua 69 
21 Padrão demográfico do perfilhamento em pastos de capim-Marandu mantidos a 40 cm de altura do dossel forrageiro por bovinos em lotação contínua .70

22 Variações no índice populacional $\left(\mathrm{P}_{\mathrm{f}} / \mathrm{P}_{0}\right)$ em pastos de capim-Marandu mantidos a $10 \mathrm{~cm}$ de altura por bovinos de corte em lotação contínua 71

23 Variações no índice populacional $\left(\mathrm{P}_{\mathrm{f}} / \mathrm{P}_{0}\right)$ em pastos de capim-Marandu mantidos a $20 \mathrm{~cm}$ de altura por bovinos de corte em lotação contínua 71

24 Variações no índice populacional $\left(\mathrm{P}_{\mathrm{f}} / \mathrm{P}_{0}\right)$ em pastos de capim-Marandu mantidos a $30 \mathrm{~cm}$ de altura por bovinos de corte em lotação contínua 72

25 Variações no índice populacional $\left(\mathrm{P}_{\mathrm{f}} / \mathrm{P}_{0}\right)$ em pastos de capim-Marandu mantidos a $40 \mathrm{~cm}$ de altura por bovinos de corte em lotação contínua 72

26 Diagrama sazonal de estabilidade em pastos de capim-Marandu mantidos em $10 \mathrm{~cm}$ do dossel forrageiro por bovinos de corte em lotação contínua .73

27 Diagrama sazonal de estabilidade em pastos de capim-Marandu mantidos em $20 \mathrm{~cm}$ do dossel forrageiro por bovinos de corte em lotação contínua .73

28 Diagrama sazonal de estabilidade em pastos de capim-Marandu mantidos em $30 \mathrm{~cm}$ do dossel forrageiro por bovinos de corte em lotação contínua .74

29 Diagrama sazonal de estabilidade em pastos de capim-Marandu mantidos em $40 \mathrm{~cm}$ do dossel forrageiro por bovinos de corte em lotação contínua .74 
30 Contribuição de folhas, hastes e material morto na formação da massa média por perfilho em pastos de capim-Marandu mantidos a $10 \mathrm{~cm}$ de altura, em diferentes épocas do ano. .77

31 Contribuição de folhas, hastes e material morto na formação da massa média por perfilho em pastos de capim-Marandu mantidos a $20 \mathrm{~cm}$ de altura, em diferentes épocas do ano. 78

32 Contribuição de folhas, hastes e material morto na formação da massa média por perfilho em pastos de capim-Marandu mantidos a $30 \mathrm{~cm}$ de altura, em diferentes épocas do ano.

33 Contribuição de folhas, hastes e material morto na formação da massa média por perfilho em pastos de capim-Marandu mantidos a $40 \mathrm{~cm}$ de altura, em diferentes épocas do ano.

34 Índice de área foliar em pastos de capim-Marandu submetidos a lotação contínua de Janeiro a Dezembro de 2002

36 Representação gráfica das taxas de crescimento, senescência e acúmulo líquido em pastos de capim-Marandu sob alturas de dossel forrageiro durante o período de verão

37 Representação gráfica das taxas de crescimento, senescência e acúmulo líquido em pastos de capim-Marandu sob alturas de dossel forrageiro durante o período de outono .95

38 Representação gráfica das taxas de crescimento, senescência e acúmulo líquido em pastos de capim-Marandu sob alturas de dossel forrageiro durante o período de inverno 
39 Representação gráfica das taxas de crescimento, senescência e acúmulo líquido em pastos de capim-Marandu sob alturas de dossel forrageiro durante o período de início de primavera .96

40 Representação gráfica das taxas de crescimento, senescência e acúmulo líquido em pastos de capim-Marandu sob alturas de dossel forrageiro durante o período de final de primavera.....

41 Relação funcional entre a taxa de alongamento foliar e o filocrono em dosséis de capim-Marandu

42 Correlação entre a área foliar específica e longevidade de folhas de capim-Marandu mantido em quatro alturas de dossel em diferentes épocas do ano

43 Relação funcional entre a área e o volume de folhas em capim-Marandu 122

44 Relação entre as taxas de remoção de forragem e de crescimento em pastos de capim-Marandu submetidos a quatro alturas de pastejo por meio de lotação contínua.

45 Proporção da forragem produzida potencialmente disponível para consumo em pastos de capim-Marandu submetidos a quatro alturas de pastejo por meio de lotação contínua 128

46 Coordenadas $\mathrm{x} / \mathrm{y}$ do $\log$ da densidade populacional e do log da massa média por perfilho em pastos de capim-Marandu em diferentes épocas do ano 132

47 Distância (em unidades logarítmicas) das coordenadas x/y da relação entre densidade populacional de perfilhos e massa e uma reta de inclinação $-3 / 2$ 136 


\section{LISTA DE TABELAS}

Página

1 Resultados da análise química do solo da área experimental.................................24

2 Relação das adubações realizadas durante o período experimental...........................32

3 Datas, número de avaliações e intervalo médio (em dias) entre as observações na avaliação de morfogênese e fluxo de tecidos. ..........................................................34

4 Datas das avaliações da demografia de perfilhamento, densidade populacional e características individuais de perfilhos.

5 Número de folhas em expansão por perfilho em pastos de capim-Marandu mantidos em quatro alturas de dossel forrageiro por meio de lotação contínua em diferentes épocas do ano 49

6 Número de folhas senescentes por perfilho em pastos de capim-Marandu mantidos em quatro alturas de dossel forrageiro por meio de lotação contínua em diferentes épocas do ano .50

7 Número de folhas vivas por perfilho em pastos de capim-Marandu mantidos em quatro alturas de dossel forrageiro por meio de lotação contínua em diferentes épocas do ano 
8 Taxa de aparecimento de folhas (folhas.perfilho ${ }^{-1} \cdot \mathrm{dia}^{-1}$ ) em pastos de capimMarandu mantidos em quatro alturas de dossel forrageiro por meio de lotação contínua em diferentes épocas do ano

9 Taxa de aparecimento de folhas (folhas.perfilho ${ }^{-1}$.graus- dia $^{-1}$ ) em pastos de capimMarandu mantidos em quatro alturas de dossel forrageiro por meio de lotação contínua em diferentes épocas do ano

10 Filocrono (dias.folha ${ }^{-1}$ ) em perfilhos de capim-Marandu mantidos em quatro alturas de dossel por meio delotação contínua em diferentes épocas do ano

11 Filocrono (graus-dia.folha ${ }^{-1}$ ) em perfilhos de capim-Marandu mantidos em quatro alturas de dossel forrageiro por meio de lotação contínua em diferentes épocas do ano

12 Filocrono (unidades fototérmicas.folha ${ }^{-1}$ ) em perfilhos de capim-Marandu mantidos em quatro alturas de dossel forrageiro por meio de lotação contínua em diferentes épocas do ano 56

13 Longevidade de folhas (dias.folha ${ }^{-1}$ ) em perfilhos de capim-Marandu mantidos em quatro alturas de dossel forrageiro por meio de lotação contínua em diferentes épocas do ano

14 Longevidade de folhas (graus.dia.folha ${ }^{-1}$ ) em perfilhos de capim-Marandu mantidos em quatro alturas de dossel forrageiro através de lotação contínua em diferentes épocas do ano .58

15 Comprimento médio de folha intacta $\left(\mathrm{cm}\right.$. folha $\left.^{-1}\right)$ em perfilhos de capim-Marandu mantidos em quatro alturas de dossel forrageiro por meio de lotação contínua em diferentes épocas do ano .59 
16 Comprimento médio da haste $(\mathrm{cm})$ em perfilhos de capim-Marandu mantidos em quatro alturas de dossel forrageiro por meio de lotação contínua em diferentes épocas do ano .60

17 Densidade populacional de perfilhos (perfilhos. $\mathrm{m}^{-2}$ ) em pastos de capim-Marandu mantidos em quatro alturas de dossel forrageiro por meio de btação contínua em diferentes épocas do ano

18 Percentual de perfilhos com inflorescência visível em pastos de capim-Marandu mantidos em quatro alturas de dossel forrageiro através de lotação contínua em diferentes épocas do ano

19 Taxa de aparecimento de perfilhos (\%) em pastos de capim-Marandu mantidos em quatro alturas de dossel forrageiro por meio de lotação contínua em diferentes épocas do ano 64

20 Taxa de sobrevivência de perfilhos (\%) em pastos de capim-Marandu mantidos em quatro alturas de dossel forrageiro por meio de lotação contínua em diferentes épocas do ano 66

21 Taxa de mortalidade de perfilhos (\%) em pastos de capim-Marandu mantidos em quatro alturas de dossel forrageiro por meio de lotação contínua em diferentes épocas do ano

22 Área foliar média por perfilho $\left(\mathrm{cm}^{2}\right)$ em pastos de capim-Marandu mantidos em quatro alturas de dossel forrageiro por meio de lotação contínua em diferentes épocas do ano .75

23 Massa média por perfilho (mg) em pastos de capim-Marandu mantidos em quatro alturas de dossel forrageiro por meio de lotação contínua em diferentes épocas do ano 
24 Área foliar específica $\left(\mathrm{cm}^{2} \cdot \mathrm{g}^{-1}\right)$ em pastos de capim-Marandu mantidos em quatro alturas de dossel forrageiro por meio de lotação contínua em diferentes épocas do ano.

25 Volume de perfilhos individuais $\left(\mathrm{cm}^{3}\right)$ em pastos de capim-Marandu mantidos em quatro alturas de dossel forrageiro por meio de lotação contínua em diferentes épocas do ano

26 Densidade aparente de perfilhos individuais $\left(\mathrm{kg} . \mathrm{m}^{-3}\right.$ de massa verde) em pastos de capim-Marandu mantidos em quatro alturas de dossel forrageiro por meio de lotação contínua em diferentes épocas do ano

27 Relação folha: haste em pastos de capim-Marandu mantidos em quatro alturas de dossel forrageiro por meio de lotação contínua em diferentes épocas do ano

28 Razão área foliar: volume por perfilho, assumindo volume calculado baseado em densidade constante de $950 \mathrm{~kg} \cdot \mathrm{m}^{-3}$, em pastos de capim-Marandu mantidos em quatro alturas de dossel forrageiro por meio de lotação contínua em diferentes épocas do ano

29 Razão área foliar: volume por perfilho, calculada com os valores de volume efetivamente medidos, em pastos de capim-Marandu mantidos em quatro alturas de dossel forrageiro por meio de lotação contínua em diferentes épocas do ano. .84

30 Índice de área foliar de pastos de capim-Marandu mantidos em quatro alturas de dossel forrageiro por meio de lotação contínua em diferentes épocas do ano 85

31 Taxa de alongamento de folhas (cm.perfilho ${ }^{-1} \cdot \mathrm{dia}^{-1}$ ) em pastos de capim-Marandu mantidos em quatro alturas de dossel forrageiro por meio de lotação contínua em diferentes épocas do ano 86 
32 Taxa de senescência de folhas (cm.perfilho ${ }^{-1} \cdot \operatorname{dia}^{-1}$ ) em pastos de capim-Marandu mantidos em quatro alturas de dossel forrageiro por meio de lotação contínua em diferentes épocas do ano .87

33 Taxa de remoção de folhas (cm.perfilho ${ }^{-1} \cdot$ dia $^{-1}$ ) em pastos de capim-Marandu mantidos em quatro alturas de dossel forrageiro por meio de lotação contínua em diferentes épocas do ano 88

34 Taxa de crescimento de folhas (kg de MS.ha ${ }^{-1} \cdot \mathrm{dia}^{-1}$ ) em pastos de capim-Marandu mantidos em quatro alturas de dossel forrageiro por meio de lotação contínua em diferentes épocas do ano

35 Taxa de crescimento de hastes (kg de MS.ha $\left.{ }^{-1} \cdot \mathrm{dia}^{-1}\right)$ em pastos de capim-Marandu mantidos em quatro alturas de dossel forrageiro por meio de lotação contínua em diferentes épocas do ano 90

36 Taxa de crescimento total ( $\mathrm{kg}$ de $\mathrm{MS} \mathrm{ha}^{-1} \cdot \mathrm{dia}^{-1}$ ) em pastos de capim-Marandu mantidos em quatro alturas de dossel forrageiro por meio de lotação contínua em diferentes épocas do ano 91

37 Taxa de senescência (kg de MS.ha ${ }^{-1} \cdot \mathrm{dia}^{-1}$ ) em pastos de capim-Marandu mantidos em quatro alturas de dossel forrageiro por meio de lotação contínua em diferentes épocas do ano 92

38 Taxa de acúmulo líquido ( $\mathrm{kg}$ de $\mathrm{MS}_{\mathrm{n}} \mathrm{ha}^{-1} \cdot \mathrm{dia}^{-1}$ ) em pastos de capim-Marandu mantidos em quatro alturas de dossel forrageiro por meio de lotação contínua em diferentes épocas do ano .93

39 Taxa de remoção de folhas ( $\mathrm{kg}$ de $\mathrm{MS} \cdot \mathrm{ha}^{-1} \cdot \mathrm{dia}^{-1}$ ) em pastos de capim-Marandu mantidos em quatro alturas de dossel forrageiro por meio de lotação contínua em diferentes épocas do ano 
40 Taxa de remoção de hastes (kg de $M S \cdot h a^{-1} \cdot$ dia $^{-1}$ ) em pastos de capim-Marandu mantidos em quatro alturas de dossel forrageiro por meio de lotação contínua em diferentes épocas do ano .99

41 Taxa de remoção total de forragem ( $\mathrm{kg}$ de $\mathrm{MS} \cdot \mathrm{ha}^{-1} \cdot \mathrm{dia}^{-1}$ ) em pastos de capimMarandu mantidos em quatro alturas de dossel forrageiro por meio de lotação contínua em diferentes épocas do ano .99

42 Parâmetros da regressão entre o Log da densidade populacional de perfilhos e o Log da massa média por perfilho. Inclinação predita estimada pressupondo uma densidade constante de $950 \mathrm{~kg} \cdot \mathrm{m}^{-3}$ no cálculo de $\mathrm{Cr}$

43 Parâmetros da regressão entre o Log da densidade populacional de perfilhos e o Log da massa média por perfilho. Inclinação predita estimada pressupondo densidade variável no cálculo de $\mathrm{Cr}$. 102

44 Coeficiente angulares das relações entre o $\log$ da densidade populacional de perfilhos e a massa média por perfilho.

45 Inclinação estimada, as correções para IAF e forma do perfilho e inclinação hipotética de uma reta de IAF constante. 135

46 Correlação (r) entre a distância de pontos de coordenadas x/y (em unidades logarítmicas) à reta de inclinação teórica -3/2 e o IAF atual do dossel. 136

47 Análise de componentes principais: eigenvalue, proporção da variância explicada por cada componente, acumulada e correlações entre os componentes e as variáveis originais 138

48 Análise de componentes principais: eigenvalue, proporção da variância explicada por cada componente, acumulada e correlações entre os componentes e as variáveis originais 139 


\section{LISTA DE ABREVIATURAS E SÍMBOLOS}

$\mathrm{ACP}=$ análise de componentes principais

$\mathrm{A}_{\mathrm{f}}=$ área foliar média por perfilho

$\mathrm{AFE}=$ área foliar específica

$\hat{\mathrm{a}}=$ Coeficiente angular

$\hat{\mathrm{a}}_{0}=$ coeficiente linear

$\mathrm{C}_{\mathrm{a}}=$ correção para variações em IAF do dossel

$\mathrm{C}_{\mathrm{d}}=$ correção para variações em densidade aparente de perfilhos

$\mathrm{C}_{\mathrm{r}}=$ correções para variação em $\mathrm{R}$

$\mathrm{CAD}=$ capacidade de armazenamento de água

$\mathrm{CFI}=$ comprimento de folhas intactas

$\mathrm{CP}=$ componente principal

$\mathrm{CPH}=$ comprimento de haste

DPP $=$ densidade populacional de perfilhos

DVF = duração de vida da folha

$\mathrm{EPM}=$ erro padrão da média

$\mathrm{FH}=$ relação folha: haste

$\mathrm{GD}=$ graus-dia

$\mathrm{IAF}=$ índice de área foliar

$\mathrm{LF}=$ longevidade de folhas

MP = massa média por perfilho

MS = matéria seca

$\mathrm{NC}=$ não calculado 
NFE $=$ número de folhas em expansão por perfilho

NFS = número de folhas senescentes por perfilho

$\mathrm{NFV}=$ número de folhas vivas por perfilho

$\mathrm{P}=$ probabilidade

$\mathrm{R}$ = razão área foliar: volume por perfilhos

$\mathrm{r}=$ coeficiente de correlação

$\mathrm{R}^{2}=$ coeficiente de determinação

$\mathrm{TAF}=$ taxa de aparecimento de folhas

$\mathrm{TAFG}=$ taxa de aparecimento de folhas em graus-dia

$\mathrm{TAlF}=$ taxa de alongamento de folhas

TAP $=$ taxa de aparecimento de perfilhos

TMP = taxa de mortalidade de perfilhos

$\mathrm{TSF}=$ taxa de senescência de folhas

TSP = taxa de sobrevivência de perfilhos

UF $=$ unidades fototérmicas

$\mathrm{V}=$ volume médio por perfilho

$\mathrm{V}: \mathrm{VL}=$ relação vermelho: vermelho longo 


\title{
MORFOGÊNESE, DINÂMICA DO PERFILHAMENTO E DO ACÚMULO DE FORRAGEM EM PASTOS DE CAPIM-MARANDU SOB LOTAÇÃO CONTÍNUA
}

\author{
Autor: ANDRÉ FISCHER SBRISSIA \\ Orientador: Prof. Dr. SILA CARNEIRO DA SILVA
}

\section{RESUMO}

É inegável que o Brasil possui condições únicas no que diz respeito à produção animal baseada em pastagens. No entanto, os avanços têm sido homeopáticos e revelam uma inércia muito grande por parte do setor produtivo e uma fragilidade conceitual na interpretação dos resultados obtidos pela pesquisa, de tal forma que o caráter dinâmico e sistêmico de ecossistemas de pastagens devem ser sempre considerados. Dentro desse contexto, o objetivo deste experimento foi estudar aspectos morfogênicos, características de perfilhos individuais e a dinâmica do perfilhamento e do acúmulo de forragem em pastos de capim-Marandu pastejados por bovinos em regime de lotação contínua e taxa de lotação variável. O experimento foi realizado em área do Departamento de Zootecnia da USP/ESALQ, em Piracicaba, SP, entre 21 de novembro de 2001 e 21 de dezembro de 2002. Os tratamentos corresponderam a quatro alturas de dossel (10, 20, 30 e $40 \mathrm{~cm})$, mantidas em steady state, e foram alocados às unidades experimentais conforme um delineamento de blocos completos casualizados, com quatro repetições. Características morfogênicas e de dinâmica do acúmulo de forragem foram avaliados em 30 perfilhos marcados por unidade experimental. Os intervalos entre as avaliações foram de 3 ou 4 dias durante o verão e com um máximo de 10 dias durante o inverno e início da primavera. As características individuais das unidades de desenvolvimento vegetativo 
foram avaliadas em 60 perfilhos colhidos em locais dos piquetes representativos da condição do dossel no momento da amostragem. As variáveis analisadas incluíram: massa, volume, área foliar média, relação folha: has te e razão área foliar: volume por perfilho. A dinâmica do perfilhamento foi avaliada em anéis de PVC de $30 \mathrm{~cm}$ de diâmetro fixados ao solo por grampos de metal. Mensalmente foram avaliadas as taxas de aparecimento, sobrevivência e mortalidade de perfilhos e relações entre elas derivadas. Os maiores valores de filocrono foram observados em pastos mantidos a 40 $\mathrm{cm}$ e os menores naqueles mantidos a $10 \mathrm{~cm}$. Além disso, houve um efeito sazonal, onde os maiores valores foram registrados durante o início da primavera e os menores no final da primavera e verão. Pastos mais baixos apresentaram maiores densidades populacionais de perfilhos pequenos e vice-versa, evidenciando o mecanismo de compensação tamanho/densidade populacional de perfilhos. No entanto, análises de estabilidade dos pastos indicaram que a densidade populacional per se não deve ser utilizada como um índice isolado de persistência ou produtividade. Os coeficientes angulares da relação $\log x \log$ entre densidade populacional de perfilhos e massa média por perfilho revelou que praticamente não houve vantagens em se manter os pastos de capim-Marandu acima de $30 \mathrm{~cm}$. Adicionalmente, o acúmulo líquido de forragem foi maximizado entre as alturas de $20-30 \mathrm{~cm}$ no período de verão e entre $10-20 \mathrm{~cm}$ nos períodos mais frios e secos do ano, indicando que o capim-Marandu possui exigências sazonais de manejo do pastejo. 


\title{
MORPHOGENESIS, TILLERING AND HERBAGE ACCUMULATION DYNAMICS IN MARANDU GRASS SWARDS UNDER CONTINUOUS STOCKING
}

\author{
Author: ANDRÉ FISCHER SBRISSIA \\ Advisor: Prof. Dr. SILA CARNEIRO DA SILVA
}

\section{SUMMARY}

Brazil is a unique environment for developing efficient and sustainable pastoral systems of animal production. Advances in this area have been modest however, resulting in slow progress and revealing deficiencies of the current conceptual basis used for interpreting results from research, particularly those related to the dynamic and systemic characteristic of plant and animal responses to management in pastoral ecosystems. Against that background, the objective of this experiment was to study the morphogenesis, characteristics of individual tillers and tillering and herbage accumulation dynamics in Marandu grass swards continuously stocked by cattle. The experiment was carried out at Departamento de Zootecnia, USP/ESALQ, Piracicaba, SP, from November 2001 to December 2002. Treatments corresponded to four steady state sward conditions (10,20, 30 and $40 \mathrm{~cm}$ sward surface height) and were allocated to experimental units according to a complete randomized block design with four replications. Morphogenetic traits and herbage accumulation dynamics were evaluated on 30 marked tillers per experimental unit. Measurements were performed every 3 or 4 days during the summer and at intervals no longer than 10 days during the winter and early spring. Characteristics of individual tillers were monitored on 60 tillers harvested 
in areas representative of the sward condition at the time of sampling. The following variables were recorded: tiller weight, volume, leaf area, leaf: stem ratio and leaf area: volume ratio. Tillering dynamics was evaluated within $30-\mathrm{cm}$ diameter PVC rings anchored to the soil. Every 30 days, rates of tiller appearance, survival and death were determined and associations between them derived. The highest and the lowest phyllochron values were recorded for the 40 and $10 \mathrm{~cm}$ swards, respectively. There was a seasonal effect characterized by highest values during early spring and lowest values during late spring and summer. Short swards showed higher tiller population densities of small tillers than tall swards and vice-versa, indicating the existence of a tiller size/population density compensation mechanism. Tiller population stability analysis indicated that population density alone cannot be used as an index for characterizing pasture persistence and productivity. Linear coefficients of the Log x Log regression between tiller population density and mean tiller weight revealed no advantages for keeping Marandu grass pastures taller than $30 \mathrm{~cm}$. Additionally, net herbage accumulation was maximized between $20-30 \mathrm{~cm}$ during the summer and $10-20 \mathrm{~cm}$ during periods of low rainfall and mild temperatures, indicating that Marandu grass has seasonal grazing management requirements. 


\section{INTRODUÇÃO}

É inegável que o Brasil possui condições únicas no que diz respeito à produção animal baseada em pastagens. No entanto, os avanços têm sido homeopáticos e revelam uma fragilidade conceitual na interpretação dos resultados obtidos pela pesquisa e uma inércia muito grande por parte do setor produtivo. Faria et al. (1996) comentaram que a pequena adoção de tecnologia pelos fazendeiros pode estar associada com a falta de incentivos econômicos. Por exemplo, o investimento em maquinarias, fertilizantes e instalações, normalmente imprescindíveis para o aumento da capacidade produtiva de pastagens, muitas vezes supera o preço pago por 1 hectare de terra em muitas regiões do País. Assim, os produtores muitas vezes preferem aumentar o capital imobilizado em terras a aumentar a produtividade daquelas ł́ existentes. A solução lógica para essa aparente dualidade seria a elevação dos custos do imóvel (no caso a terra), que só seria possível, num sistema capitalista, por meio da lei de oferta e demanda. No entanto, há indícios de que esse quadro esteja próximo a se inverter, uma vez que a ocupação dos Cerrados, última grande fronteira agrícola do mundo, vem ocorrendo rapidamente, o que certamente pressionará para que os preços da terra aumentem, como já está ocorrendo em algumas regiões do Brasil, particularmente no Sul e Sudeste. O alto custo da terra provavelmente modificaria o enfoque dos produtores, fazendo-os olhar mais para "dentro" da fazenda. Além disso, a ausência de políticas econômicas adequadas para o setor, o baixo nível de escolaridade dos produtores e as persistentes falhas no sistema de extensão rural são fatores que também contribuem para a baixa produtividade do sistema pecuário brasileiro. 
No que diz respeito à contribuição da pesquisa, Faria et al. (1996) analisaram mais de 1000 resumos publicados em Reuniões Anuais da Sociedade Brasileira de Zootecnia (SBZ) e verificaram que a maior parte dos trabalhos envolvendo plantas forrageiras havia sido conduzida sem a presença de animais e que, portanto, contribuíam muito pouco com informações essenciais para a implementação de práticas eficientes de manejo, apesar de fornecerem dados de outra natureza. Por outro lado, dos trabalhos realizados com animais, apenas alguns encerraram dados de controle efetivo do uso da forragem produzida no sistema e, geralmente, foram baseados em taxas de lotação e/ou intervalos entre cortes ou pastejos fixos, o que, na maior parte das vezes, não ilustra as mudanças líquidas na massa de forragem produzida e na estrutura do dossel. O resultado direto disso são as aparentes contradições nos resultados da pesquisa e o insucesso na repetição dos experimentos conduzidos. Assim, nessa enorme base de resultados e informações, as propostas de métodos de manejo são basicamente fruto de objetivos e hipóteses carentes de sustentação científica, muitas vezes idiossincráticas.

Dessa forma, a mudança conceitual da pesquisa implica no reconhecimento do caráter sistêmico e dinâmico do ecossistema de pastagem em que os universos envolvidos e suas interações (solo:planta:animal:ambiente) sejam, sempre que possível, considerados. Isso significa dizer que pesquisas com pastagens deveriam ser realizadas dentro de um contexto multidisciplinar onde as respostas em cada componente, de cada universo, fossem analisadas de maneira sistêmica e integrada. Uma síntese dessa visão holística da ciência pode ser encontrada em outras áreas do conhecimento, como a física por exemplo. Parafraseando Capra (1983), "Existe ação, mas não há movimento; existe atividade, mas não há atores, não existem dançarinos, apenas a dança".

Além disso, o aparente retardo entre os resultados de pesquisa e sua aplicação no campo não devem servir como agente desestimulante, uma vez que é próprio da ciência estar na vanguarda do conhecimento científico. Da mesma maneira, a inversão dessa lógica, ou seja, ficar à espera do que ser pesquisado a fim de atender uma dada demanda, pode ser pernicioso e, geralmente, conduz a uma letargia muito difícil de ser revigorada. 


\section{REVISÃO DE LITERATURA}

\subsection{Perfilho: a unidade básica de gramíne as}

Em gramíneas, a unidade básica é o perfilho, cujo desenvolvimento morfológico está baseado na sucessiva diferenciação de fitômeros em diferentes estádios de desenvolvimento (Valentine \& Matthew, 1999) a partir do meristema apical (Briske, 1991). Um fitômero (também chamado de metâmero por alguns autores (Howard, 1974; White, 1979, 1984; Rutishauser \& Sattler, 1985; Sattler \& Rutishauser, 1997)) é formado basicamente por uma folha (lâmina e bainha), internó e um nó com sua respectiva gema axilar (Evans \& Grover, 1940; Nelson, 2000).

A produção de tecidos em um perfilho é caracterizada pelo crescimento de novos órgãos, como folhas e hastes. Além disso, sempre que o meristema apical produz uma nova folha (dando início, portanto, a um novo fitômero) uma nova gema é produzida, a qual se localiza na axila da folha anteriormente formada (Jewiss, 1972). Dessa forma, cada nó possui uma gema axilar que, potencialmente, pode dar origem a um novo perfilho (Jewiss, 1972). As condições para essa gema se desenvolver estão basicamente associadas com características hormonais e de ambiente (Murphy \& Briske, 1992).

O crescimento não é o único processo determinante da produção vegetal num ambiente de pastagem, existindo outros processos que ocorrem de forma simultânea, fazendo com que a produção de forragem seja o resultado do balanço líquido entre eles. Assim, o acúmulo de tecidos "novos" pela planta forrageira (crescimento) ocorre simultaneamente à perda de tecidos "velhos" por senescência e morte (Hodgson, 1990), 
um equilíbrio que opera em perfilhos individuais e evidencia a contínua substituição de fitômeros na unidade de crescimento. O conjunto de perfilhos (densidade populacional), associado aos padrões de perfilhamento (aparecimento, mortalidade e sobrevivência), determina a produção da comunidade vegetal (Da Silva \& Pedreira, 1997).

\subsection{Morfogênese de plantas forrageiras e estrutura do relvado}

A estrutura de um dossel forrageiro é definida por um conjunto de características genéticas da espécie, denominadas características morfogênicas, que são condicionadas por fatores de ambiente como luz, temperatura, umidade e outros (Lemaire \& Chapman, 1996). A dinâmica da geração ("genesis”) e da expansão da forma da planta ("morphos") no espaço definem a morfogênese das plantas (Chapman \& Lemaire, 1993), a qual pode ser descrita a partir de três características básicas:

a) taxa de aparecimento de folhas (TAF): número de folhas que aparece em cada perfilho por unidade de tempo. Seu inverso, o filocrono, determina o intervalo de tempo necessário para o aparecimento de duas folhas consecutivas e é, normalmente, expresso em graus-dia.

b) taxa de alongamento foliar (TAlF): é o efeito cumulativo da divisão e alongamento celular (Schnyder et al., 2000).

c) duração de vida da folha (DVF): intervalo de tempo no qual uma dada folha permanece verde, ou seja, do seu aparecimento até a senescência.

A combinação dessas características morfogênicas determina as três principais características estruturais do dossel forrageiro:

a) tamanho da folha: produto da taxa de expansão foliar e a duração do período de alongamento para uma dada folha. Robson (1967) e Dale (1982) mostraram que esse 
período é proporcional ao intervalo de aparecimento, resultando numa proporcionalidade entre o tamanho final e a relação TAlF/TAF.

b) densidade populacional de perfilhos: diretamente influenciada pela TAF, através da determinação do número potencial de gemas e do "site filling" que, juntos, determinam a taxa de aparecimento de perfilhos (TAP) (Davies, 1974). O equilíbrio entre a TAP e a taxa de mortalidade de perfilhos (TMP) determina a população de perfilhos do relvado.

c) número de folhas vivas por perfilho $(N F V)$ : diretamente influenciada pela TAF e pela DVF. Seu valor, normalmente, é específico para cada espécie.

O produto dessas três características determina diretamente o índice de área foliar (IAF) do dossel. Em plantas tropicais e subtropicais, o alongamento de hastes assume importância relativa grande como característica morfogênica e determina variáveis estruturais do dossel como a relação folha: haste, por exemplo (Sbrissia \& Da Silva, 2001).

É a contínua emissão de folhas e perfilhos que promove a restauração da área foliar após a desfolhação por corte ou pastejo, assegurando a produtividade e a perenidade da pastagem (Gomide \& Gomide, 1999). De acordo com Chapman \& Lemaire (1993), a taxa de aparecimento de folhas é a característica morfogênica que merece maior destaque, uma vez que influencia diretamente as três características estruturais do relvado: tamanho da folha, densidade populacional de perfilhos e número de folhas por perfilho. Zarrough et al. (1984) revelaram uma correlação negativa entre a taxa de aparecimento e o alongamento das folhas, indicando que quanto maior a taxa de aparecimento, menor o tempo para o alongamento.

Folhas apresentam um tempo de vida limitado, o qual é determinado por características genéticas e influenciado por fatores de ambiente e de manejo (Hodgson et al., 1981). Uma vez iniciado o processo de senescência ou morte da folha, ela passa a perder massa progressivamente. Qualquer prática de manejo que resulte em redução da disponibilidade de fatores de crescimento, principalmente luz, pode ocasionar 
incremento no processo de senescência das folhas reduzindo, assim, sua longevidade (Hodgson et al., 1981).

Existe um sincronismo entre o aparecimento e a morte de folhas percebido com mais facilidade em pastos mantidos em condições de equilíbrio, onde o número de folhas mantidas vivas em cada perfilho permanece constante após algum tempo (Lemaire \& Chapman, 1996). Esse número é função da taxa de aparecimento e do tempo de vida de cada folha, ambas características morfogênicas. Depois de atingida a condição de equilíbrio em um dossel forrageiro, o número de folhas vivas por perfilho fica relativamente constante para plantas de um mesmo cultivar ou espécie (Gomide, 1997; Van Esbroeck et al., 1997). Por ser resultado da combinação de características morfogênicas, sofre influência direta e indireta de fatores relacionados ao ambiente e às práticas de manejo utilizadas (Gomide, 1997).

\subsection{O processo de acúmulo de forragem em pastagens}

De acordo com Da Silva \& Pedreira (1997), o acúmulo de forragem em pastagens é o resultado de interações complexas advindas da combinação dos atributos genéticos de uma dada espécie e os efeitos do ambiente sobre seus processos fisiológicos e características morfofisiológicas para a determinação da produtividade. Hodgson et al. (1981) definiram o acúmulo de forragem da pastagem como sendo um

processo dinâmico e resultado do balanço entre crescimento e senescência/decomposição de tecidos. No caso específico de plantas sob pastejo, considera-se no balanço o material consumido pelos animais, tornando o acúmulo de forragem o balanço líquido entre o crescimento, consumo e as perdas por senescência (Bircham \& Hodgson, 1983). Em casos onde a pastagem é mantida em condição de equilíbrio (e.g. altura constante), como em alguns casos de lotação contínua, o acúmulo de forragem pode chegar a zero, quando todo material produzido é removido por meio do pastejo (Bircham \& Hodgson, 1983). 
O desenvolvimento vegetativo de uma gramínea é caracterizado pela produção de tecidos que originam folhas e perfilhos, o alongamento do colmo e o aparecimento do sistema radicular (Silsbury, 1970). Essa produção de massa seca é originada a partir da energia luminosa interceptada pelo dossel forrageiro e da capacidade deste em transformar essa energia quando somada a outros nutrientes nos tecidos vegetais. Cooper \& Wilson (1970) relataram que a taxa de transformação da energia luminosa em tecidos é dependente da eficiência fotossintética de folhas individuais, de características do dossel para interceptar a luz incidente, e da distribuição dos tecidos produzidos ao longo do perfil do dossel forrageiro.

Folhas são formadas a partir do desenvolvimento de primórdios foliares que surgem na forma de pequenas protuberâncias, alternadamente de cada lado do domo apical (Langer, 1972), em posições regulares, definidas e características para cada espécie de planta forrageira (Pinto et al., 1994). Cada primórdio foliar dá origem a um fitômero constituído de lâmina e bainha foliares, entrenó, nó e gema (Wilhelm \& McMaster, 1995). Segundo Hodgson (1990), a produção de folhas num perfilho é um processo contínuo, onde cada uma das folhas apresenta características próprias em seu ciclo de vida, como um período de ativa expansão (crescimento), uma fase de máximo desempenho fotossintético (maturidade) seguida de uma fase de senescência e, por fim, morte, caso essa folha não venha a ser colhida. As primeiras folhas, emergindo de uma haste curta, têm uma rápida emergência e atingem pequenos comprimentos. As folhas seguintes, por necessitarem percorrer um percurso mais longo para emergir, alcançam comprimentos maiores (Skinner \& Nelson, 1995).

Quando a planta forrageira entra em estádio reprodutivo e dá início ao alongamento da haste, cessa o aparecimento de novas folhas e, com isso, a produção de massa seca de folhas desse perfilho. Enquanto a haste reprodutiva não for cortada ou morrer, novas folhas não voltam a aparecer nesse perfilho (Hodgson, 1990). Brougham (1956), trabalhando em condições de lotação intermitente, relacionou a produção de massa seca à interceptação de luz pelo dossel forrageiro e mencionou que esta apresentou valores crescentes até que existisse área foliar suficiente para interceptar 95\% da luz incidente, patamar onde ocorreu a máxima taxa de acúmulo líquido de 
forragem nos pastos de azevém perene (Lolium perenne, L.) estudados. Acima de $95 \%$ de interceptação de toda luz incidente passa a existir uma acirrada competição por esse fator de produção, levando ao decréscimo na taxa de crescimento e acentuando-se o processo de senescência.

Segundo Parsons et al. (1983a), a fisiologia de um pasto submetido a condições de rebrotação ou crescimento e de outro mantido com área foliar relativamente constante é bastante diferente. No caso da rebrotação, onde o relvado parte de uma área foliar inicial pequena crescendo até adquirir área foliar grande, a fotossíntese bruta cresce conforme o aumento em área foliar, sendo acompanhada da taxa de produção de novos tecidos. Nessa condição, é percebido um atraso entre o processo de produção de tecidos e a senescência ou morte dos mesmos, originando uma fase em que a taxa de acúmulo de forragem é máxima. Passada essa fase, ou nos relvados mantidos sob área foliar relativamente constante e suficiente para interceptar $95 \%$ de toda luz incidente, deixa de existir vantagem entre a taxa de produção de tecidos e o processo de senescência foliar, uma vez que embora exista uma alta taxa fotossintética e, com isso, de produção bruta de tecidos, ocorre também uma alta taxa de senescência e morte desses tecidos. Nessas condições, caso o pasto continue crescendo e intercepte praticamente toda a luz incidente, o processo de senescência assume tal proporção que se iguala à produção de tecidos, resultando em acúmulo líquido de forragem igual a zero (Parsons et al., 1983b) ou até mesmo negativo.

A senescência é um processo natural para o qual existe uma programação genética da planta forrageira (Salisbury \& Ross, 1992). Como consequiência da limitada longevidade das folhas, após um determinado tempo de vida fenômenos fisiológicos que determinam o processo de senescência são desencadeados (Hodgson, 1990). Nesse instante, as folhas perdem clorofila, RNA e proteínas, inclusive enzimas (Salisbury \& Ross, 1992), provocando a mudança da coloração do tecido foliar para tons amarelados e, posteriormente, amarronzados e enegrecidos (Wilman \& Mares Martin, 1977). Nos estádios iniciais, muitos dos compostos solúveis podem ser remobilizados para uso em outras partes da planta. No entanto, a maior parte deles acaba sendo utilizada para respiração da folha e de bactérias e fungos que vivem sobre seu limbo. O mesmo efeito 
pode acometer os perfilhos como um todo, sendo esse normalmente desencadeado quando o meristema apical é removido por corte ou pastejo (Hodgson, 1990). Parsons et al. (1988) ponderaram que ao maximizar a fotossíntese e a taxa de produção total de tecidos, acaba-se favorecendo uma elevada taxa de senescência de tecidos caso não haja tempo hábil ou número de animais suficiente para colheita. Porém, é necessário conviver com patamares aceitáveis de senescência em função da necessidade de assegurar a produção animal por meio de ofertas generosas de forragem, muitas vezes bastante acima da capacidade de ingestão do animal (Nabinger, 1997).

Características relacionadas ao ambiente e às práticas adotadas de manejo da desfolhação apresentam interferência sobre a dinâmica do acúmulo de forragem. O fator de ambiente mais influente é a luz, pois potencializa a produção de tecidos quando abundante e induz a senescência dos mesmos quando em quantidade insuficiente (Brougham, 1956). Limitações de água e outros nutrientes também interferem em ambos os processos.

\subsection{Comunidade de plantas forrageiras - populações de perfilhos}

Durante as primeiras etapas de crescimento, a taxa de produção de folhas e de perfilhos é linear, mas como esse é um processo contínuo para todas as plantas, o aumento no número total de perfilhos do relvado é exponencial enquanto não houver limitação no meio (Langer, 1963). Uma vez atingido o equilíbrio com a disponibilidade de luz na área, inicia-se um processo de morte de perfilhos dependente da densidade populacional, resultando num balanço dinâmico entre número e peso (tamanho) de perfilhos (Matthew et al., 1995; Sbrissia et al., 2001, 2003). Parsons et al. (1988) mencionou que a pesquisa em manejo do pastejo tem por objetivo encontrar o ponto ótimo entre a necessidade da planta forrageira de conservar sua área foliar e a prerrogativa fundamental de remover esse tecido via corte ou pastejo para a manutenção da produção animal. Dentre os fatores que afetam o fluxo de tecidos, o perfilhamento é o que exerce a maior influência sobre as variáveis de acúmulo de forragem (Da Silva \& 
Pedreira, 1997), sendo sua dinâmica determinada por diversos fatores: genótipo da planta, balanço hormonal, estádio de desenvolvimento (vegetativo x reprodutivo), fotoperíodo, temperatura, intensidade luminosa, disponibilidade de nutrientes e água (Langer, 1963).

A premissa básica da produção animal em pastagens é a remoção e o consumo da área foliar das plantas forrageiras para alimentação animal, que acaba por promover alterações e ajustes no crescimento e na população de perfilhos (Grant \& King, 1983). Alterações na área foliar, medidas pelo índice de área foliar (IAF), influenciam diretamente a capacidade de interceptação luminosa da planta e do dossel, promovendo mudanças tanto em suas características morfogênicas, pela alteração nas taxas de alongamento e aparecimento de folhas, quanto em suas características estruturais, quer diretamente sobre a densidade populacional de perfilhos, quer indiretamente pelos efeitos derivados da alteração nas taxas de aparecimento e alongamento de folhas. Essas mudanças visam assegurar a rebrotação e a perenidade da planta forrageira, e integram um conjunto de características adaptativas chamadas plasticidade fenotípica (Lemaire \& Chapman, 1996). Como o tamanho e o número de folhas por perfilho têm plasticidade limitada, o ajuste no IAF do pasto é feito com maior rapidez a partir de variações na população de perfilhos (Matthew et al., 2000), sendo que quanto maior o nú mero de perfilhos maior a competição entre eles por luz e, com isso, menor seu desenvolvimento e tamanho final. A contrapartida também é válida, ou seja, quanto menor o número de perfilhos, maior seu desenvolvimento (Briske, 1996). De acordo com Bircham \& Hodgson (1983), é esse mecanismo de controle "homeostático" de comunidades de plantas em pastagens o responsável pelas mudanças na dinâmica populacional de perfilhos, promovendo o ajuste entre o peso e número dos mesmos de maneira a minimizar o efeito da desfolhação sobre o IAF do pasto. Hodgson (1990) descreveu com detalhes o ciclo de vida de uma comunidade de perfilhos, apontando que os perfilhos surgem, desenvolvem-se, aumentam de tamanho e acabam promovendo um "autodesbate" em perfilhos mais fracos, localizados mais próximos do solo, onde a luminosidade é baixa. Contudo, quanto maior o tamanho dos perfilhos, menor o número 
de perfilhos que podem ser mantidos na área (Matthew et al., 1995; Sbrissia et al., 2001, 2003).

\subsection{Perfilhamento}

Perfilhos possuem um ciclo de vida mais ou menos determinado, quando são então substituídos por fitômeros jovens. Essa organização dos perfilhos na forma de uma cadeia sequencial de fitômeros confere aos mesmos duas características importantes: (1) capacidade de substituição de perfilhos que vão morrendo e (2) proteção de meristemas contra o processo de desfolhação (Valentine \& Matthew, 1999).

Muitos fatores afetam o perfilhamento das plantas forrageiras. De acordo com Langer (1979), a produção de perfilhos é controlada pela disponibilidade de água, luz, temperatura e nutrientes, principalmente nitrogênio e, em menor escala, fósforo e potássio, além do estádio de desenvolvimento da planta (reprodutivo ou vegetativo). A ação de todos esses fatores em conjunto determina o aparecimento e a morte de perfilhos que acontecem em todos os meses do ano (Langer, 1958). A perenidade de plantas individuais, e conseqüentemente do pasto, depende da capacidade de substituição dos perfilhos mortos, que também é afetada pelos picos estacionais de morte e aparecimento, especialmente aqueles associados com eventos de florescimento. Se a substituição de perfilhos falhar, a planta morre. Adicionalmente, se a utilização do pasto for incorreta e a morte de perfilhos for consistentemente maior que o aparecimento, o pasto entra em processo de degradação (Marshall, 1987).

A morte de perfilhos pode ter diferentes causas. Uma delas é a remoção dos ápices pelos animais em pastejo. Esse fenômeno é particularmente importante em pastagens no estádio reprodutivo, quando os meristemas são elevados pelo alongamento dos internódios das hastes até o horizonte de desfolhação. Mas, mesmo em pastagens vegetativas de algumas espécies como azevém perene, o regime de desfolhação leniente pode induzir o alongamento dos internódios basais e aumentar o risco de decapitação dos meristemas apicais (Davies, 1988). Algumas gramíneas tropicais são particularmente vulneráveis à remoção dos ápices das hastes (Chapman \& Lemaire, 
1993). Uma outra causa importante da morte de perfilhos em pastagens densas é o balanço negativo de energia, resultado da competição por luz. Davies et al. (1983) demonstraram que uma quantidade maior de fotoassimilados era alocada para o crescimento de perfilhos existentes em relação àquela alocada para odesenvolvimento de novos perfilhos em plantas sombreadas. Perfilhos jovens são os primeiros a morrer por serem sobrepostos e sombreados por perfilhos maduros (Ong et al., 1978) e algumas gemas de perfilhos são provavelmente abortadas, antes mesmo da emergência de novos perfilhos em dosséis sombreados (Lemaire \& Chapman, 1996).

O equilíbrio entre o aparecimento e a morte de perfilhos é extremamente dependente do regime de desfolhação adotado que, por sua vez, determina a evolução do IAF, aparentemente fator chave no controle tanto do aparecimento como da morte de perfilhos (Valantine \& Matthew, 1999). Para grande parte das pastagens de azevém perene manejadas intermitentemente, a densidade populacional de perfilhos aumenta após a desfolhação até que um IAF em torno de 3-4 seja atingido, ponto a partir do qual começa a diminuir (Lemaire \& Chapman, 1996). Em manejo caracterizado por lotação contínua, a densidade populacional de perfilhos é determinada principalmente pelo IAF no qual o dossel é mantido, sendo que pastagens que sofrem desfolhações severas têm maior densidade populacional de perfilhos que pastagens manejadas lenientemente (Grant et al., 1983).

\subsection{Compensação tamanho/densidade populacional de perfilhos em pastagens}

Enquanto diferenças em aspectos morfogênicos entre espécies ou cultivares como a taxa de aparecimento de folhas, por exemplo, podem determinar todas as características estruturais do pasto, variações no fenótipo, expressas por um genótipo em resposta a variações de ambiente e/ou manejo, também influenciam sobremaneira a estrutura de um dossel forrageiro. Esse fenômeno é conhecido como plasticidade fenotípica (Bradshaw, 1965) e é importante na adaptação de plantas forrageiras à desfolhação, sendo expressa como modificações morfológicas progressivas e reversíveis 
em plantas individuais. Comunidades de plantas em pastagens condicionam-se às diferentes frequiências e intensidades de desfolha por meio de mecanismos que visam assegurar sua perenidade e eficiência fotossintética. O principal componente estrutural do dossel forrageiro sensível a essas adaptações é o IAF (Lemaire \& Chapman, 1996) e uma comunidade de plantas pode otimizá-lo de diversas maneiras. Como abordado anteriormente, a análise dos componentes do IAF mostra que este é composto por três características estruturais distintas do dossel (Matthew et al., 2000): densidade populacional de perfilhos, número de folhas por perfilho e tamanho da folha.

O número de folhas vivas por perfilho é um valor relativamente constante para uma dada espécie (Davies, 1977; Yang et al., 1998; Carnevalli \& Da Silva, 1999). Já a área foliar é determinada basicamente pelo comprimento da folha que, por sua vez, é controlado pela intensidade de desfolhação. Dessa forma, a densidade populacional de perfilhos é o componente do IAF que permite a maior flexibilidade de ajuste por parte da planta forrageira a diferentes regimes de desfolhação (Matthew et al, 2000). Se o suprimento de assimilados for menor que a demanda para o crescimento de folhas, a planta limita o número de meristemas ativos (reduz a densidade populacional de perfilhos) para manter o potencial de crescimento de folhas no perfilho principal. Por essa razão, enquanto a taxa de expansão de folhas em perfilhos maduros é muito pouco afetada pelo suprimento de carbono, o perfilhamento é determinado por variações no nível de radiação (Lemaire \& Agnusdei, 2000).

O aumento no IAF, por causar alteração na qualidade do ambiente luminoso dentro do dossel pode modificar algumas variáveis morfogênicas de perfilhos individuais, como a TAF e a taxa de perfilhamento e, consequentemente, mudar, também, as características estruturais do pasto como a densidade populacional e o tamanho dos perfilhos (Deregibus et al., 1983). A otimização do IAF de um dossel em situações de altura de desfolhação baixa é alcançada por meio de uma alta densidade populacional de perfilhos pequenos (Matthew et al., 2000). Entretanto, com desfolhações drásticas, o IAF do dossel e o suprimento de fotoassimilados podem ser reduzidos a tal ponto que a produção de novos perfilhos é diminuída e a densidade populacional de perfilhos também diminui à medida que os perfilhos existentes morrem 
(Matthew et al., 2000). Atingido o ponto de máxima taxa média de acúmulo líquido de forragem, os fatores de crescimento passam a ser limitantes, acentuando-se o processo de competição entre os perfilhos.

O fator de maior competição, sob condições ótimas de meio ambiente, é a luz. A ativação de gemas e a produção de novos perfilhos são dadas pela relação vermelho: vermelho longo da radiação incidente, relação essa que é reduzida à medida que se aumenta a área foliar do dossel (Matthew et al., 2000). Provavelmente, devido a isso, a produção de novos perfilhos pára antes da área foliar de equilíbrio ser alcançada.

A relação inversa entre densidade populacional e tamanho individual de perfilhos em comunidades de plantas forrageiras submetidas a desfolhação tem sido descrita para muitas pastagens de gramíneas (Grant et al., 1983; Lambert et al., 1986; Davies, 1988). Em relvados que não sofreram desfolhação, a compensação tamanho/densidade foi observada segundo uma reta de inclinação $-3 / 2$ (detalhes sobre o conceito podem ser obtidos em Yoda et al, 1963, Matthew et al., 1995, Sackville-Hamilton et al., 1995 e Sbrissia et al., 2001, 2003), exceto em condições de nível baixo de luminosidade (Kays \& Harper, 1974; Lonsdale \& Watkinson, 1982). Tem-se assumido, genericamente, que pastos sob desfolhação deveriam seguir a mesma lei (Bircham \& Hodgson, 1983; Lambert et al., 1986; Xia, 1991). No entanto, análise visual (sem tratamento estatístico) dos dados de Davies (1988) sugeriu uma sistemática falta de ajuste à inclinação teórica de $-3 / 2$. Matthew (1992) também observou inclinação maior que $-3 / 2$ em pastos de azevém perene sob desfolhação. Matthew et al. (1995) argumentaram que em pastos sob desfolhação um diagrama multifásico de compensação tamanho/densidade seria esperado, isto é, existiriam quatro fases, cada uma delas representando diferentes situações do estado da pastagem. Segundo esses autores, as 4 fases seriam: (1) massa de forragem baixa (tamanho pequeno de perfilhos) - nível de energia no perfilho seria baixo e o pasto teria aparecimento de novos perfilhos insuficiente para atingir a linha -3/2 de auto-desbaste por meio do aumento no número de perfilhos; (2) área foliar variável (fase de rebrotação) - auto-desbaste segundo uma inclinação -5/2; (3) área foliar constante - autodesbaste segundo uma inclinação -3/2; e (4) massa de forragem constante (situação hipotética) - auto-desbaste segundo uma inclinação -1 . O ponto de 
transição entre as fases (2) e (3) seria considerado como um indicador da altura de dossel ideal para a desfolhação de uma determinada espécie ou cultivar, uma vez que se a rebrotação prosseguisse além desse ponto a perda de perfilhos passaria a ser maior para um aumento correspondente em massa de forragem (Sbrissia \& Da Silva, 2001).

O equilíbrio é claramente dinâmico e as respostas compensatórias entre tamanho e densidade populacional de perfilhos em comunidades de plantas submetidas a desfolhação, o que resulta em pequenas diferenças na quantidade total de folhas produzidas por unidade de área, como foi demonstrado em estudos com pastagens sob lotação contínua mantidas em diferentes alturas de dossel (Grant et al.1983; Bircham \& Hodgson, 1983). Resultados semelhantes em termos de produção de folhas por unidade de área também foram obtidos quando variações em tamanho/densidade populacional de perfilhos tinham origem genética, como mostrado por Mazzanti et al. (1994) na comparação entre dois cultivares de festuca (Festuca arundinacea (Schreb)).

A discussão sobre plasticidade fenotípica de gramíneas e leguminosas leva ao conceito de limites da resposta plástica (Briske, 1996) das plantas forrageiras, e a considerações de como esses limites podem ser definidos e utilizados para relacionar espécies forrageiras ou genótipos ao melhor regime de desfolhação e, dessa forma, otimizar o crescimento do pasto no longo prazo, dentro da heterogeneidade temporal e espacial das pastagens (Lemaire \& Chapman, 1996). Esses limites podem determinar uma série de alternativas de manejo do pastejo, dentro das quais a compensação entre, por exemplo, tamanho e densidade populacional de unidades de crescimento individuais, possa operar para manter uma produção ótima de forragem. Da mesma forma, o conhecimento dos limites plásticos de uma espécie ou cultivar é importante para que esses não sejam transpostos, o que poderia levar ao colapso da condição de equilíbrio da pastagem e iniciar rapidamente um processo de degradação se correções rápidas no manejo da desfolhação não forem realizadas (Matthew et al., 1995). 


\subsection{Variações estacionais em densidade populacional de perfilhos}

Experimentos comparando diferentes freqüências e intensidades de desfolhação geralmente parecem insuficientes para explicar mudanças na densidade populacional de perfilhos. Na maioria das gramíneas, a vida média de um perfilho é menor do que um ano e, por isso, é esperado que variações estacionais de energia luminosa provoquem variações na linha limítrofe de área foliar e, com isso, variações estacionais na densidade populacional de perfilhos (Matthew et al., 2000). A persistência de uma pastagem é definida como a manutenção da população de plantas e sua prod ução ao longo do tempo, mesmo considerando as interferências estacionais e de manejo (Matthew et al., 2000). Muitas espécies de plantas possuem um padrão estacional de aparecimento e morte de perfilhos. A maior variação estacional característica da estratégia de perenização de plantas forrageiras está geralmente associada a fenômenos de florescimento. Existem diferenças entre espécies e até mesmo entre cultivares quanto ao padrão estacional, assim como diferenças inexplicáveis na densidade populacional entre anos sucessivos considerando-se uma mesma espécie ou cultivar (Matthew et al., 2000). Estudos sobre demografia de populações de perfilhos parecem ser uma boa ferramenta para se prever essas variações e, com isso, determinar uma estratégia de manejo do pastejo adequada para manter uma densidade populacional de perfilhos que vise a otimização da produção de forragem ao longo do ano (Lemaire \& Chapman, 1996).

Vários métodos de monitoramento da dinâmica de perfilhamento têm sido empregados nos estudos sobre demografia de perfilhos. No caso mais simples, a contagem do número de perfilhos por planta ou da população de perfilhos em tempos regulares é utilizada, e para muitos objetivos isso é tudo que se requer. Para estudos mais detalhados, o monitoramento de perfilhos marcados permite que mudanças na densidade populacional sejam explicadas a partir do aparecimento e morte de perfilhos.

Adicionalmente, maior nível de detalhamento pode ser obtido por meio do monitoramento da sobrevivência de gerações sucessivas de perfilhos marcados em áreas fixas ao longo de um dado período de tempo. Como refinamento, para uma análise demográfica completa, é necessário não só monitorar-se a sobrevivência, mas também a 
organização hierárquica das gerações de perfilhos surgidas. Essa técnica requer geralmente o corte dos perfilhos das áreas de monitoramento, o que exige um número muito grande de áreas de amostragem (Matthew et al., 2000).

Matthew et al. (2000) sumarizaram treze experimentos detalhados sobre demografia de perfilhos na forma de diagramas. Pela análise desses diagramas, ficou claro que em muitos casos existiu um aumento ou diminuição estacional distinto nas taxas de aparecimento e morte de perfilhos, que poderia estar associado a estratégias de persistência das plantas, e que esses padrões eram diferentes entre espécies de gramíneas. Para a espécie Phleum pratense L. (Jewiss, 1966), a análise do diagrama revelou um mecanismo de persistência que Matthew et al. (1993) denominaram mecanismo "reprodutivo", pois a renovação da pastagem ocorreu principalmente em associação com o florescimento, e a maioria dos perfilhos de reposição foi formada na base de perfilhos reprodutivos que haviam sido decapitados. Para festuca, Jewiss (1966) observou uma estratégia de persistência baseada em altas taxas de aparecimento de perfilhos na primavera, perfilhos esses que apresentavam uma tendência de persistir até o florescimento do próximo ano. Já o cultivar Lolium multiflorum cv. 'S22' Lam apresentou alta mortalidade de perfilhos jovens durante o período de verão, fato esse atribuído ao florescimento de perfilhos não vernalisados (Matthew et al, 2000).

Para paspalum (Paspalum notatum Flugge) (Pakiding \& Hirata, 1998), observouse uma estratégia de persistência na qual novos perfilhos eram formados numa taxa praticamente constante ao longo do ano, supostamente a maioria desses tendo sido originada de perfilhos não florescidos. Uma estratégia similar foi observada para Lolium perenne cv. "Grasslands Ruanui" (Matthew, 1992), caracterizada por Mat thew et al. (1993) como um mecanismo "vegetativo" de persistência. Entretanto, apesar da similaridade de padrão de renovação, perfilhos de paspalum apresentaram uma vida média mais longa (321-902 dias) do que perfilhos de Lolium perenne cv. 'Grasslands Rua nui' (aproximadamente 90-150 dias).

O estudo da variação sazonal na densidade populacional de perfilhos por meio de alterações nas taxas de aparecimento e mortalidade de perfilhos reveste-se de grande importância no sentido de permitir melhor compreensão dos mecanismos envolvidos na 
estabilidade e perenidade das pastagens. Além disso, o detalhamento de tais processos permitiria a manipulação e possíveis aumentos na capacidade produtiva dos pastos e, conseqüentemente, na produtividade da pecuária como um todo.

\subsection{Manipulação da estacionalidade da demografia populacional de perfilhos para fins de manejo do pastejo}

O conhecimento das estratégias de perenização de cultivares ou espécies forrageiras permite a identificação de regimes de manejo do pastejo que aumentem a produtividade por permitir que o ciclo natural de reposição de perfilhos seja potencializado, assegurando condição para que a população de plantas possa ajustar-se de forma rápida aos regimes de desfolhação impostos e restaurar seu IAF "ideal” para uma dada localidade e época do ano (Valentine \& Matthew, 1999). A manipulação da dinâmica de perfilhos numa pastagem deve ser um dos objetivos do manejo do pastejo, principalmente em situações onde a densidade populacional de perfilhos tende para um mínimo necessário para garantir a perenização da pastagem (Lemaire \& Chapman, 1996).

A partir da análise de dados sobre demografia de perfilhos, Matthew et al. (2000) observaram que pastejos mais lenientes na primavera aumentaram consistentemente a renovação da população de perfilhos em pastos de azevém perene no verão, talvez por permitir que os perfilhos atingissem um maior tamanho, favorecendo o seu florescimento e, com isso, aumentando a magnitude do evento de renovação no segundo, comparado ao primeiro, ano após o estabelecimento do pasto. Para Lolium perenne cv. 'Ellett', na Nova Zelândia, grande renovação de perfilhos foi associada ao florescimento e, por isso, $52 \%$ da sua população de perfilhos em meados de dezembro era composta de perfilhos novos, formados a partir da base de perfilhos reprodutivos. Reconhecendo essa estratégia particular de perenização dos cultivares modernos de Lolium perenne na Nova Zelândia, uma série de experimentos foi realizada visando determinar-se uma estratégia de manejo do pastejo que permitisse aumentar o processo de reposição de perfilhos. 
De forma geral, a decapitação atrasada de perfilhos reprodutivos na primavera aumentou a produção de perfilhos filhos a partir da base de perfilhos reprodutivos, quando comparado com a decapitação mais precoce ou a não decapitação, e a desfolhação mais leniente favoreceu a produção de perfilhos filhos relativamente à desfolhação drástica (Matthew, 1992). Essas respostas foram relacionadas à maior transferência de radiocarbono dos perfilhos pais para os perfilhos filhos (Matthew, 1992, Matthew, 2002). Adicionalmente, o relaxamento da pressão de pastejo na primavera visando permitir o acúmulo de substrato nos perfilhos em florescimento antes da desfolhação, aumentou consistentemente a densidade populacional de perfilhos no final do verão e a produtividade de forragem em 0,9 t.ha $^{-1}$ de MS em média, considerando-se cinco experimentos separados.

A espécie Bromus willdenowii Kunth utiliza o mecanismo "reprodutivo" de perenização, ou seja, possui uma alta porcentagem de florescimento e a sua persistência depende da formação de perfilhos de reposição no início do verão. Um pastejo severo no início de primavera, um pouco antes do alongamento de hastes, prejudicou a reposição de perfilhos. Assim, a estratégia de atrasar a desfolhação por um mês nesse período, e depois realizar um pastejo severo, permitiu um perfilhamento vigoroso a partir da base de perfilhos florescidos decapitados e uma população adequada de perfilhos para a próxima estação. A realização de uma desfolhação leniente no início de outubro provocou uma resposta intermediária. Como conseqüência, a produção de massa seca em um período de 13 meses a partir de outubro até novembro do próximo ano foi de 8,7, 16,5 e 12,8 t.ha ${ }^{-1}$ de MS para os tratamentos com desfolhação "severa", "severa mas atrasada" e "leniente", respectivamente (Black e Chu, 1989).

Da mesma forma, Lemaire \& Culleton (1989) mostraram que um manejo de desfolhação no outono associado a um suprimento adequado de nitrogênio pode aumentar o perfilhamento durante o inverno e o crescimento subsequente da pastagem na primavera para festuca Os resultados gerais dos estudos de demografia do perfilhamento apontam o potencial que a manipulação das taxas de aparecimento e morte de perfilhos pode ter sobre a produção de forragem. Pouca ou nenhuma informação é disponível para gramíneas tropicais, especialmente o capim-Marandu, uma 
das espécies de maior representatividade nas áreas de pastagens cultivadas no país e de grande potencial de produção.

\subsection{Hipótese e objetivos}

O estudo e a reflexão sobre as respostas funcionais de plantas forrageiras ao pastejo apresentadas nessa revisão de literatura, revelaram um padrão de resposta da comunidade de plantas e de suas unidades de crescimento (perfilhos) análogo para espécies forrageiras de morfologia e fisiologia bastante diferenciadas. Com base nessa percepção, formulourse a hipótese de que o mesmo padrão de respostas seria seguido por espécies tropicais e subtropicais, variando a ordem de grandeza e a velocidade dos processos envolvidos em função das características específicas dessas plantas forrageiras e do ambiente onde se desenvolvem. Tal premissa, se verdadeira, permitiria um rápido e consistente avanço da pesquisa acerca do manejo do pastejo de plantas forrageiras tropicais pois implicaria no uso e aproveitamento apropriado de toda a base e massa crítica de conhecimentos já gerada e disponível na literatura internacional. Adicionalmente, o processo de pastejo poderia ser controlado, monitorado e planejado a partir de metas de condições e/ou estrutura do dossel forrageiro, imprimindo um caráter científico, objetivo e prático na tomada de decisões em sistemas de produção animal em pastagens. Esse fato tornaria possível a análise comparativa de ecofisiologia das plantas forrageiras de climas temperado, tropical e subtropical, potencializando ações e otimizando o uso de recursos globais.

Dessa forma, este trabalho teve por objetivo avaliar os padrões demográficos do perfilhamento, o mecanismo de compensação tamanho/densidade populacional de perfilhos, a morfogênese e a dinâmica do acúmulo de matéria seca em pastos de capimMarandu submetidos a diferentes alturas de dossel forrageiro utilizando-se de técnica de lotação contínua com taxa de lotação variável como forma de gerar condições de equilíbrio contrastantes que permitissem explorar e caracterizar as respostas funcionais dessa importante espécie forrageira. 


\section{MATERIAL E MÉTODOS}

\subsection{Material}

\subsubsection{Espécie vegetal}

A espécie estudada classifica-se, de acordo com o "Sistema Cronquist" (Cronquist, 1988) como divisão Magnoliophyta; classe Liliopsida; subclasse Commelinidae; ordem Cyperales; família Poaceae; subfamília Panicoideae; Tribo Panicodae; subtribo Paniceae; gênero Urochloa; espécie Urochloa brizantha (Hochst. ex A. Rich.) Webster; variedade Urochloa brizantha (Hochst. ex A. Rich.) Webster cv Marandu.

A espécie em questão é tradicionalmente conhecida como Brachiaria brizantha (Hochst. ex A. Rich) e possui diversas denominações regionais como: brizantão, brizantha, braquiarão, capim Marandu, capim Ocinde e Marandu (Renvoize et al., 1998). No entanto, Webster (1987), revisando diversos gêneros de gramíneas, concluiu que várias espécies do gênero Brachiaria pertenciam na verdade ao gênero Urochloa. Da mesma maneira, Morrone \& Zuloaga (1992), numa extensa revisão sobre os dois gêneros, concluíram que no continente americano o gênero Brachiaria se fazia representar, até aquela data, por apenas uma espécie introduzida: Brachiaria eruciformis (Smith) Griseb.. Apesar disso, não existe consenso entre os especialistas sobre o correto nome científico dessa planta, de tal forma que durante o decorrer desse texto será utilizado o nome capim-Marandu, uma vez que é termo de uso corrente tanto por parte de produtores quanto pesquisadores brasileiros. 


\subsubsection{Características gerais}

De acordo com Nunes et al. (1985), o capim-Marandu é uma planta cespitosa, muito robusta, de 1,5 a 2,5 m de altura, com colmos iniciais prostrados, mas produzindo perfilhos predominantemente eretos. Seus rizomas são muito curtos e encurvados. Os colmos floríferos são eretos, freqüentemente com perfilhamento nos nós superiores, o que leva à proliferação de inflorescências que atingem até $40 \mathrm{~cm}$ de comprimento, geralmente com quatro a seis rácemos. A ráquis da inflorescência é estreita e tem forma de meia-lua. As espiguetas são unisseriadas ao longo da raque, oblongas a elípticooblongas, com 5 a 5,5 $\mathrm{mm}$ de comprimento por 2 a 2,5 $\mathrm{mm}$ de largura, esparsamente pilosas no ápice. Possuem bainhas pilosas com cílios nas margens, geralmente mais longas que os entrenós, escondendo-os nos nós, o que confere a impressão de haver densa pilosidade nos colmos vegetativos. Suas lâminas foliares são do tipo linearlanceoladas, esparsamente pilosas na face ventral e glabras na face dorsal.

Sua capacidade de adaptação às mais variadas condições de ambiente (Ghisi \& Pedreira, 1987), especialmente em sistemas de produção com reduzido uso de insumos, é uma das principais responsáveis por sua expansão e expressividade (Andrade, 1994).

Soares Filho et al. (1992) mencionou que esse cultivar adapta-se a condições de até $3000 \mathrm{~m}$ de altitude, precipitação anual ao redor de $700 \mathrm{~mm}$ e cerca de cinco meses de seca no inverno. Não suporta solos encharcados e é recomendada para áreas de média a boa fertilidade, embora tolere acidez no solo. A temperatura ótima para seu crescimento está entre 25 a $30{ }^{\circ} \mathrm{C}$, sendo a mínima de $15{ }^{\circ} \mathrm{C}$, embora tolere bem a ocorrência de geada (Skerman \& Riveros, 1992).

\subsubsection{Local do experimento}

O experimento foi conduzido na Unidade Experimental de Plantas Forrageiras (UEPF) (Figura 1), em área do Departamento de Zootecnia da Escola Superior de 
Agricultura 'Luiz de Queiroz”, da Universidade de São Paulo, em Piracicaba (2242’ S, $47^{\circ} 37^{\prime} \mathrm{W}, 550 \mathrm{~m}$ alt).

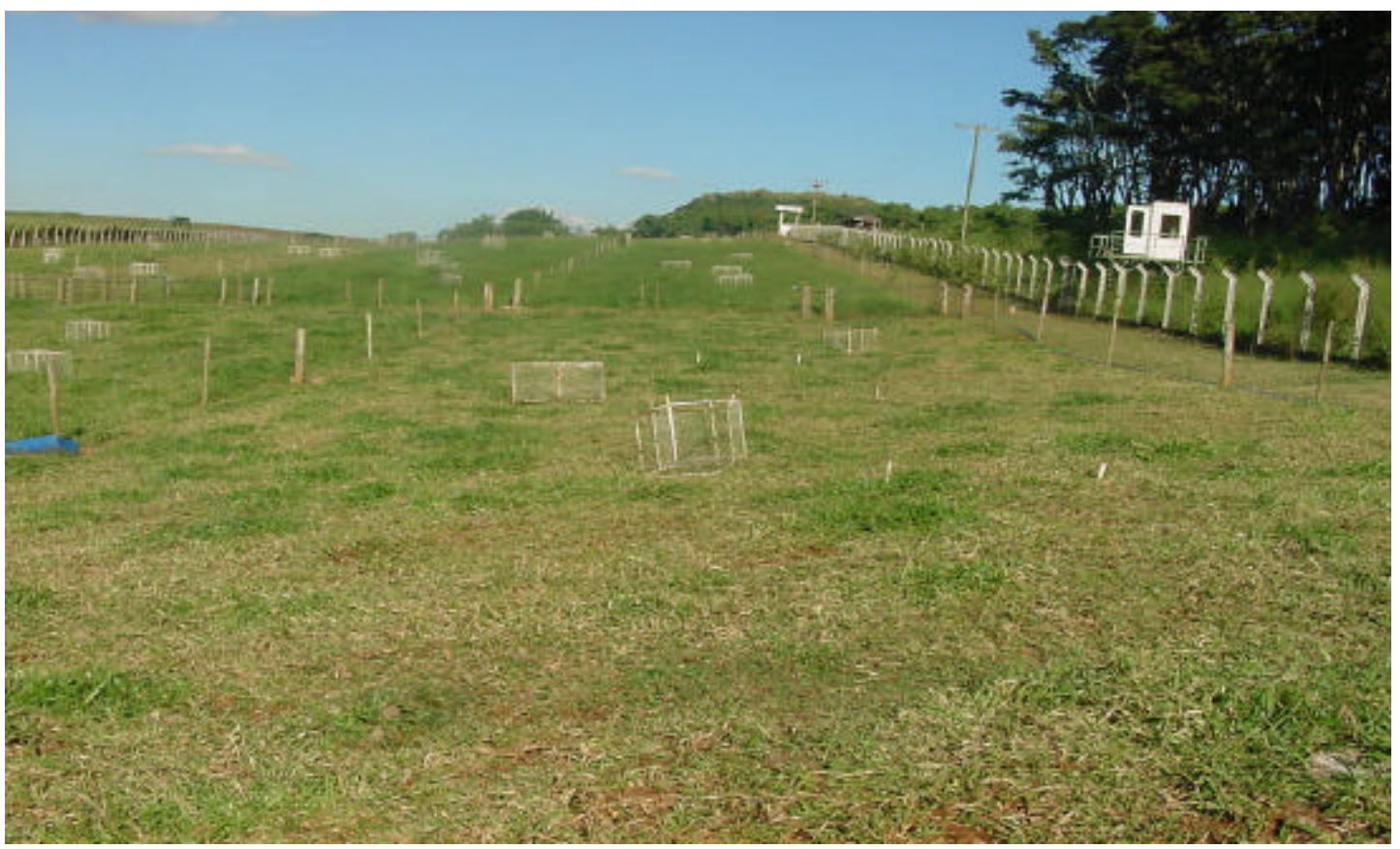

Figura 1 - Vista geral da área experimental

\subsubsection{Solo da área experimental}

O solo da área é um Nitossolo Vermelho eutroférrico, com horizonte A moderado e textura variando de argilosa a muito argilosa (EMBRAPA, 1999). Antes do estabelecimento dos pastos foram realizadas amostragens para avaliação da fertilidade do solo (Tabela 1). Devido aos valores satisfatórios de $\mathrm{pH}$ e dos teores de nutrientes em relação às exigências da espécie em estudo (Raij et al., 1996), não foi realizada correção do solo no momento do estabelecimento. 
Tabela 1. Resultados da análise química do solo da área experimental

\begin{tabular}{|c|c|c|c|c|c|c|c|c|c|c|c|}
\hline \multicolumn{2}{|c|}{ Parcela } & $\begin{array}{c}\mathrm{pH} \\
\mathrm{CaCl}_{2}\end{array}$ & $\begin{array}{l}\text { M.O. } \\
\mathrm{dg} \mathrm{dm}^{-3}\end{array}$ & 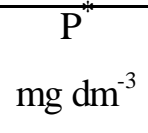 & \multicolumn{6}{|c|}{ mmol $\mathrm{dm}^{-3}$} & $\begin{array}{l}\mathrm{V} \\
\%\end{array}$ \\
\hline \multirow{4}{*}{$\begin{array}{l}\overline{0} \\
\overline{0} \\
\vec{n}\end{array}$} & 10 & 5,6 & 44 & 64 & 73 & 22 & 11,4 & 29 & 106,4 & 135,4 & 79 \\
\hline & 20 & 5,9 & 48 & 52 & 60 & 19 & 7,1 & 28 & 86,1 & 114,1 & 75 \\
\hline & 30 & 5,9 & 44 & 59 & 69 & 23 & 6,8 & 28 & 98,8 & 126,8 & 78 \\
\hline & 40 & 6,0 & 44 & 47 & 74 & 26 & 6,2 & 24 & 106,2 & 130,2 & 82 \\
\hline \multirow{4}{*}{ 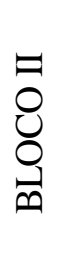 } & 10 & 5,7 & 44 & 58 & 56 & 19 & 6,5 & 33 & 81,5 & 114,5 & 71 \\
\hline & 20 & 5,8 & 46 & 51 & 59 & 18 & 7,8 & 33 & 84,8 & 117,8 & 72 \\
\hline & 30 & 5,6 & 40 & 51 & 59 & 19 & 8,6 & 31 & 86,6 & 117,6 & 74 \\
\hline & 40 & 5,7 & 40 & 58 & 49 & 18 & 7,4 & 29 & 74,4 & 103,4 & 72 \\
\hline \multirow{4}{*}{ 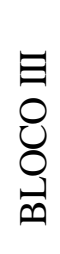 } & 10 & 5,6 & 41 & 61 & 88 & 20 & 5,9 & 36 & 113,9 & 149,9 & 76 \\
\hline & 20 & 5,5 & 43 & 56 & 72 & 16 & 5,6 & 34 & 93,6 & 127,6 & 73 \\
\hline & 30 & 5,5 & 40 & 80 & 63 & 19 & 7,4 & 36 & 89,4 & 125,4 & 71 \\
\hline & 40 & 5,5 & 41 & 82 & 81 & 20 & 5,7 & 36 & 106,7 & 142,7 & 75 \\
\hline \multirow{4}{*}{ 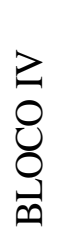 } & 10 & 5,2 & 35 & 89 & 91 & 14 & 5,9 & 45 & 110,9 & 155,9 & 71 \\
\hline & 20 & 5,2 & 37 & 84 & 111 & 17 & 5,2 & 47 & 133,2 & 180,2 & 74 \\
\hline & 30 & 5,0 & 38 & 80 & 86 & 11 & 2,5 & 55 & 99,5 & 154,5 & 64 \\
\hline & 40 & 5,2 & 38 & 96 & 93 & 15 & 3,5 & 50 & 111,5 & 161,5 & 69 \\
\hline
\end{tabular}

Extrator de fósforo: resina trocadora de íons (Raij et al., 1986)

\subsubsection{Clima}

\subsubsection{Classificação}

Segundo o sistema Köppen, o clima da região de Piracicaba é classificado como Cwa, ou seja, mesotérmico úmido, subtropical de inverno seco, onde a temperatura 
média do mês mais frio é inferior a $18^{\circ} \mathrm{C}$ e a do mês mais quente ultrapassa $22^{\circ} \mathrm{C}$ (Brasil, 1960).

\subsubsection{Dados climáticos durante o período experimental}

Os dados climáticos referentes ao período experimental foram coletados no posto meteorológico do Departamento de Ciências Exatas da USP/ESALQ, localizado a aproximadamente $500 \mathrm{~m}$ da área experimental (Figuras 2, 3 e 4 e Apêndice 1). Na Figura 5 e no Apêndice 2 estão mostrados os resultados do balanço hídrico decendial entre os meses de novembro de 2001 e dezembro de 2002. Os valores apresentados foram determinados considerando-se uma CAD (capacidade de armazenamento de água) de $50 \mathrm{~mm}$

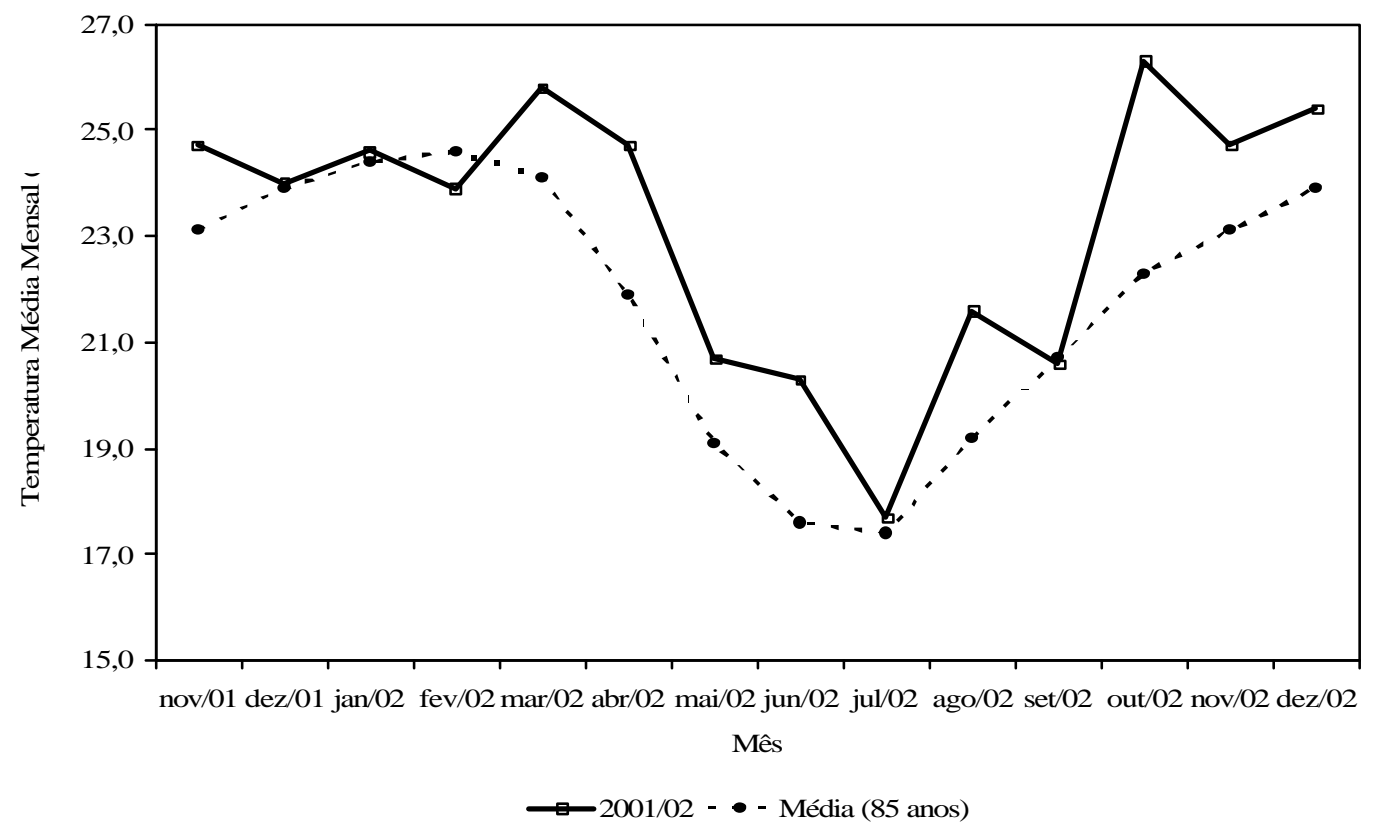

Figura 2 - Temperaturas médias mensais durante o período experimental comparada com a média dos últimos 85 anos (1917-2002) 


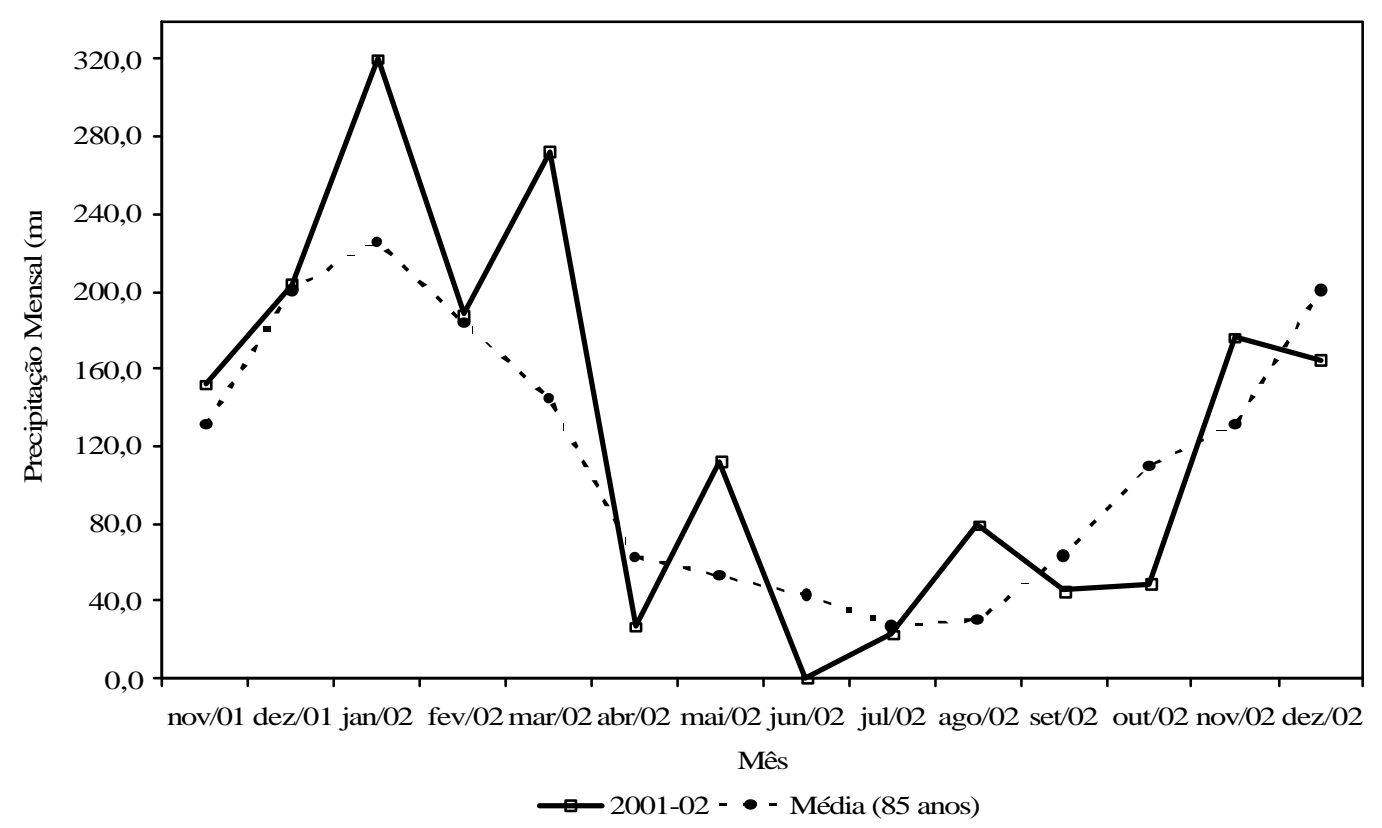

Figura 3 - Totais mensais da precipitação durante o período experimental comparada com a média dos últimos 85 anos (1917-2002)

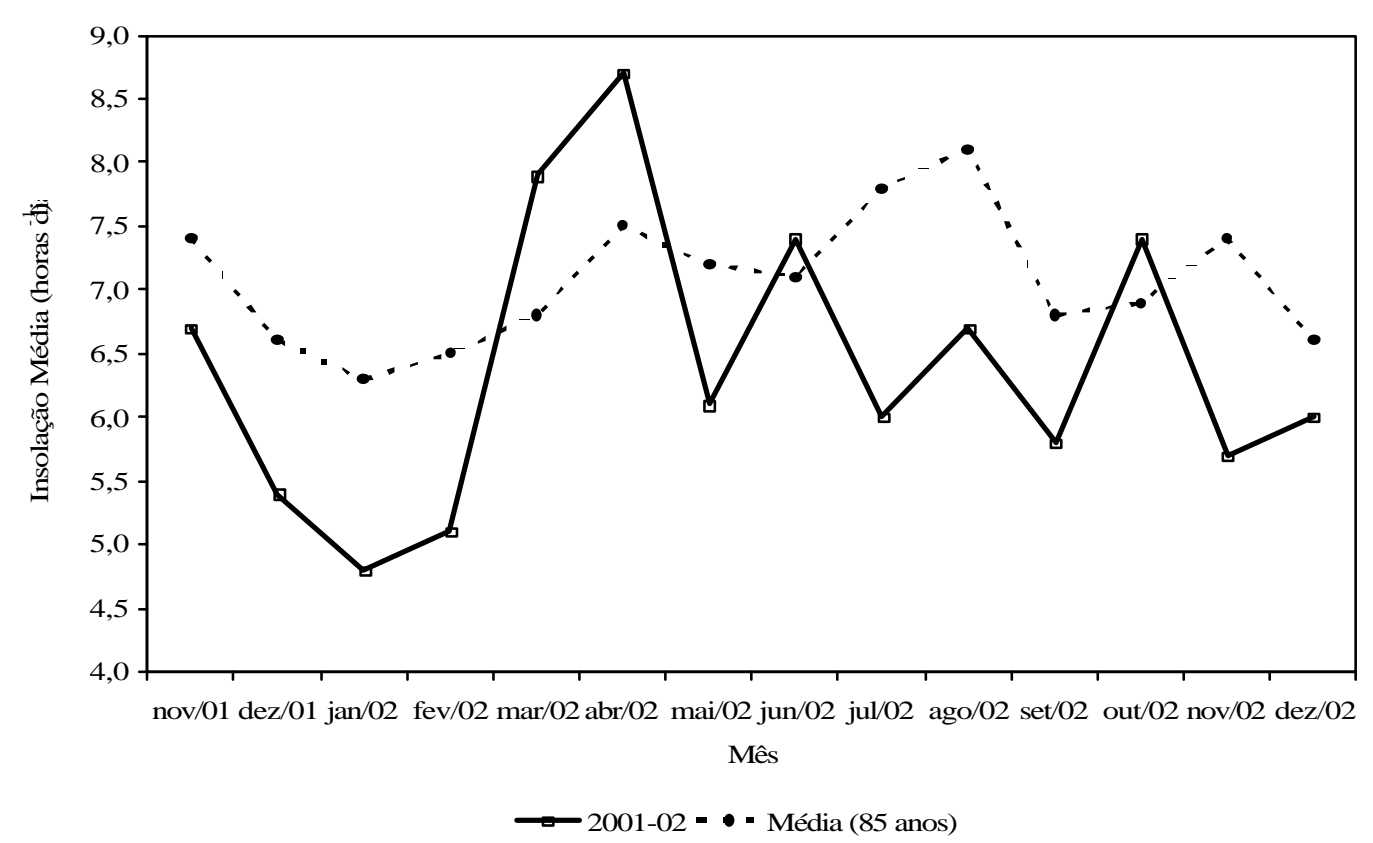

Figura 4 - Distribuição da insolação média durante o período experimental comparada com a média dos últimos 85 anos (1917-2002) 


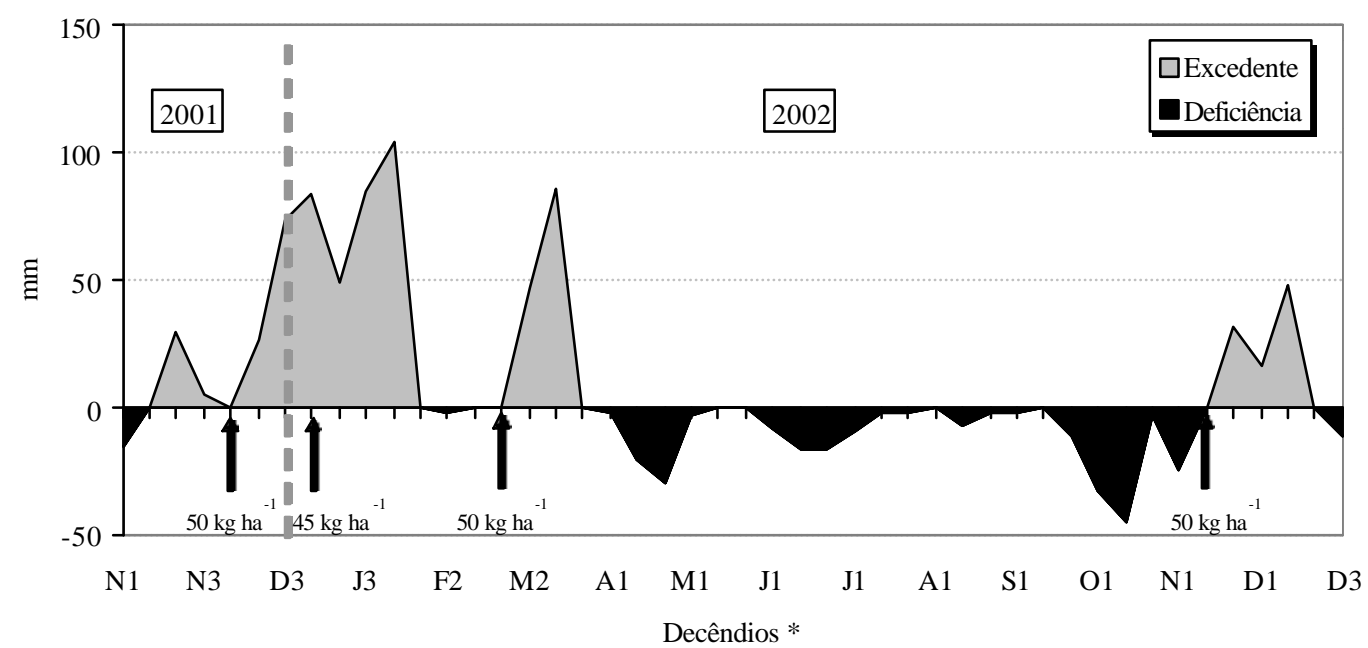

Figura 5 - Extrato do balanço hídrico dos decêndios mensais do período de novembro de 2001 a dezembro de 2002 (CAD = $50 \mathrm{~mm}$ ) e épocas de adubação nitrogenada

* Os símbolos no eixo $\mathrm{X}$ indicam as iniciais dos meses de cada ano. Dessa forma, N1 corresponde ao primeiro decêndio do mês de novembro e assim sucessivamente

\subsubsection{Animais}

Para a manutenção das condições experimentais foram utilizados bovinos de corte das raças Nelore e Canchim oriundos do plantel do Departamento de Zootecnia da USP/ESALQ. Em virtude da reduzida área experimental, optou-se por animais jovens e relativamente leves. Foram selecionadas 30 novilhas desmamadas da raça Nelore, com média inicial de $215 \mathrm{~kg}$, destinadas aos blocos I e III, e outras 30 novilhas desmamadas da raça Canchim, com peso médio inicial de $250 \mathrm{~kg}$, destinadas aos blocos II e IV. Os animais foram pareados em função do peso vivo e alocados (dois a dois) às unidades experimentais a partir de 26 de setembro de 2001. Com o transcorrer do experimento, o peso dos animais se tornou muito elevado (peso médio de $310 \mathrm{~kg}$ ) razão pela qual foram substituídos por um novo lote de animais que passou a ser utilizado a partir de 18 de junho de 2002. O principal problema do peso estava associado com as dimensões da 
unidade experimental, incapaz de suportar, dentro das condições propostas, a manutenção de pelo menos dois animais durante os períodos de avaliação. Esse lote, composto de 31 animais da raça nelore e 26 da raça canchim, possuía um peso médio de $160 \mathrm{~kg}$, e foi utilizado até o término do experimento em 19 de dezembro de 2002.

\subsection{Métodos}

\subsubsection{Delineamento experimental e tratamentos}

$\mathrm{O}$ experimento foi realizado seguindo um delineamento de blocos completos casualizados, com quatro repetições. As razões para o bloqueamento foram o histórico anterior da área e sua inclinação no sentido norte-sul. Os tratamentos corresponderam a quatro alturas do dossel forrageiro $(10,20,30$ e $40 \mathrm{~cm})$ mantidas "constantes" por meio da adição ou retirada dos animais das unidades experimentais. Portanto, durante todo o período de avaliação, adotou-se a técnica de lotação contínua com taxa de lotação variável. Dessa forma, o experimento apresentou um total de 16 unidades experimentais ou parcelas (4 blocos x 4 unidades experimentais por bloco), com uma área média de $1.200 \mathrm{~m}^{2}$ cada, separadas por cerca de arame liso de $1,30 \mathrm{~m}$ de altura com quatro fios para delimitação dos piquetes (parcelas) e contenção dos animais. A área experimental total utilizada foi de cerca de 2,0 hectares. O período experimental teve início em 21/11/2001 e terminou em 21/12/2002, totalizando 395 dias.

\subsubsection{Instalação do experimento}

\subsubsection{Semeadura}

A semeadura teve início em 30/09/2000. Foram aplicados $7 \mathrm{~kg}$ de sementes puras viáveis por hectare utilizando-se uma semeadora-adubadora de quatro linhas, com sistema de distribuição gravimétrico de fluxo contínuo, adaptada para o sistema de 
plantio direto. Devido ao grande número de falhas, foram necessárias intervenções e adotada a repicagem e plantio de mudas do mesmo capim em dezembro de 2000, objetivando uma maior ocupação da área.

Em janeiro de 2001 foram realizadas duas roçadas severas nos pastos em um curto intervalo de tempo (12 dias). Sua severidade e o período de deficiência hídrica moderada posterior a elas promoveu a morte de um grande número de touceiras, prejudicando o estabelecimento da pastagem. Tentou-se, a princípio, promover o restabelecimento apenas nos pontos mais prejudicados por semeadura a lanço no dia 11 de abril de 2001. No entanto, o efetivo estabelecimento da área só foi alcançado após a semeadura em área total, com $10 \mathrm{~kg}$ de sementes puras viáveis por hectare, utilizando-se uma semeadora-adubadora de 20 linhas com sistema de distribuição gravimétrico de fluxo contínuo, específica para o sistema de plantio direto, no dia 21 de maio de 2001.

\subsubsection{Controle de plantas daninhas}

A área experimental era formada anteriormente por pastagens do gênero Cynodon. Para promover seu controle e permitir que a semeadura pudesse ser realizada, foram efetuadas aplicações de herbicida dessecante à base de Glyphosate, na dosagem de $2,4 \mathrm{~kg}$ de ingrediente ativo (ia). $\mathrm{ha}^{-1}$.

Após a semeadura, as espécies invasoras que causaram os maiores problemas ao estabelecimento dos pastos foram os capins Tifton-85 (Cynodon nlemfuensis Vanderyst x PI 290884), Florakirk (Cynodon dactylon (L.) Pers) e Coastcross (Cynodon dactylon (L.) Pers. cv. Coastal x Cynodon nlemfuensis Vanderyst. var. robustus cv. Coastcross), pé-de-galinha (Eleusine indica L.) e rabo de raposa (Setaria geniculata (Lam.) Beauv.), o caruru (Amaranthus deflexus L..), a beldroega (Portulaca oleraceae L.), e a corda-deviola (Ipomoea grandifolia (Dammer) O’Don.). O controle dessas espécies foi efetuado por meio de arranquio e capinas freqüentes e uso do herbicida diclorofenoxiacético em área total, na dosagem de $2,4 \mathrm{~kg}$ de ia.ha ${ }^{-1}$, ou de forma dirigida sobre as plantas invasoras com o herbicida Glyphosate, na dosagem de 2,4 kg de ia.ha ${ }^{-1}$. A partir de maio 
de 2001, a ação física de controle recebeu o reforço do pastejo seletivo efetuado por eqüinos e muares do Departamento de Zootecnia da USP/ESALQ, principalmente no combate a maior invasora, o Cynodon.

\subsubsection{Monitoramento das condições experimentais}

\subsubsection{Alturas dos tratamentos}

A partir de uma roçada realizada em 28 e 29 de agosto de 2001, foi iniciado o monitoramento da altura do dossel nas parcelas. Esse cortrole era realizado a intervalos de 3 e 4 dias ( 2 vezes por semana), em 20 pontos em cada unidade experimental, com o uso de transparência e régua graduada (Fagundes et al., 1999). Animais eram adicionados quando a altura do relvado apresentava-se acima do determinado para o tratamento, e retirados quando essa ficava abaixo do esperado. A princípio esperava-se uma variação da ordem de 10 a 15\%, mas, em determinados momentos, como ocorreu em janeiro, julho, setembro e outubro de 2002, a necessidade de permanência dos animais por um período maior de tempo para que avaliações simultâneas de comportamento animal em experimento concomitante fossem realizadas causou decréscimo mais drástico na altura e massa de forragem dos tratamentos de 30 e $40 \mathrm{~cm}$ (Figura 6 e Apêndice 3). 


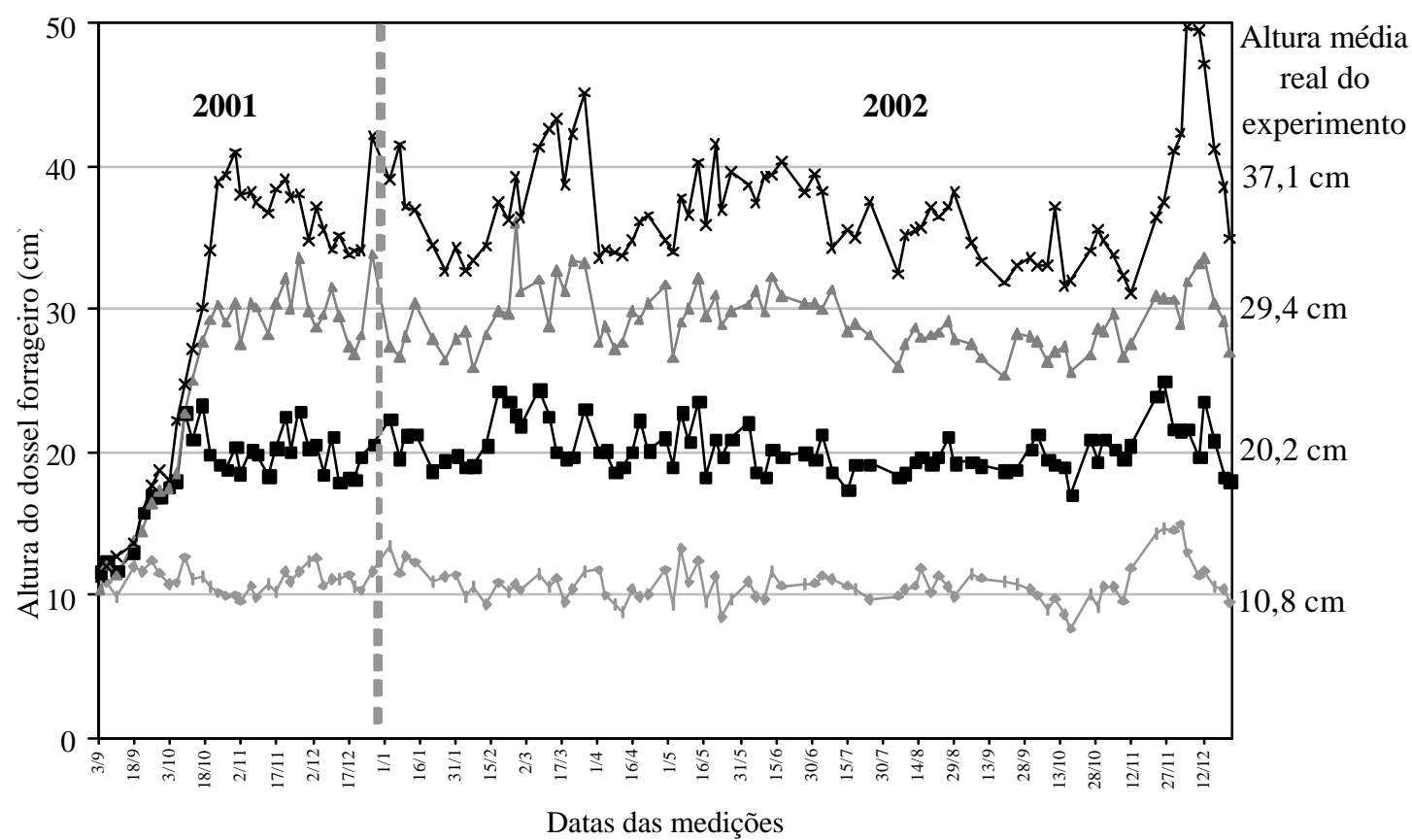

Figura 6 - Valores médios das alturas dos tratamentos ao longo do período experimental. Alturas dos tratamentos: 10, 20, 30 e $40 \mathrm{~cm}$

\subsubsection{Fertilização e tratos culturais}

Para assegurar a permanência dos animais pelo maior período de empo possível nas parcelas experimentais a partir de produção e oferta abundantes de forragem, foram realizadas adubações estratégicas com nitrogênio e potássio. A seqüência de adubações desde a implantação da área experimental está ilustrada na Tabela 2. 
Tabela 2. Relação das adubações realizadas durante o período experimental

\begin{tabular}{cccc}
\hline Data & $\begin{array}{c}\text { Quantidade de } \\
\text { nitrogênio aplicada } \\
(\mathrm{kg} \mathrm{de} \mathrm{N} \mathrm{por} \mathrm{ha)}\end{array}$ & $\begin{array}{c}\text { Quantidade de } \\
\text { potássio aplicada } \\
\left(\mathrm{kg} \mathrm{de} \mathrm{K}_{2} \mathrm{O} \text { por ha }\right)\end{array}$ & Fertilizante \\
\hline $07 / 11 / 2001$ & 66 & 20 & Nitrato de amônio \\
$01 / 12 / 2001$ & 30 & 30 & 30.00 .20 \\
$10 / 01 / 2002$ & 45 & & 30.00 .20 \\
$07 / 03 / 2002$ & 115 & & Uréia \\
$30 / 10 / 2002$ & 46 & 50 & Uréia \\
Total & 302 & &
\end{tabular}

\subsubsection{Avaliações de campo}

\subsubsection{Morfogênese e dinâmica do acúmulo de massa seca}

Com o objetivo de se avaliar as características morfogênicas e a dinâmica do acúmulo de massa seca de forragem (taxas de crescimento e senescência), foram marcados diversos perfilhos do capim-Marandu em todas as unidades experimentais e ao longo de todo o período experimental (Grant \& Marriot, 1994). A marcação dos perfilhos deu-se com o auxílio de barras de metal de 2 metros de comprimento, graduadas a cada 20 centímetros (Bircham \& Hodgson, 1983). Essas barras receberam a denominação de réguas transectas. As réguas (três por parcela) foram colocadas em pontos da unidade experimental que fossem representativos da condição do relvado e apresentassem a altura média do tratamento, e sua posição foi demarcada com o uso de estacas para facilitar sua localização (Figura 7). Para cada régua foram selecionados 10 perfilhos, espaçados de 20 centímetros cada, e identificados por meio de anel plástico colorido (Bircham \& Hodgson, 1983) (Figura 8). Dessa forma, foram selecionados 30 perfilhos por unidade experimental, o que totalizou 120 perfilhos marcados por tratamento. A cada ciclo de coleta de dados, de no mínimo quatro semanas, um novo grupo de perfilhos era selecionado para avaliação. 


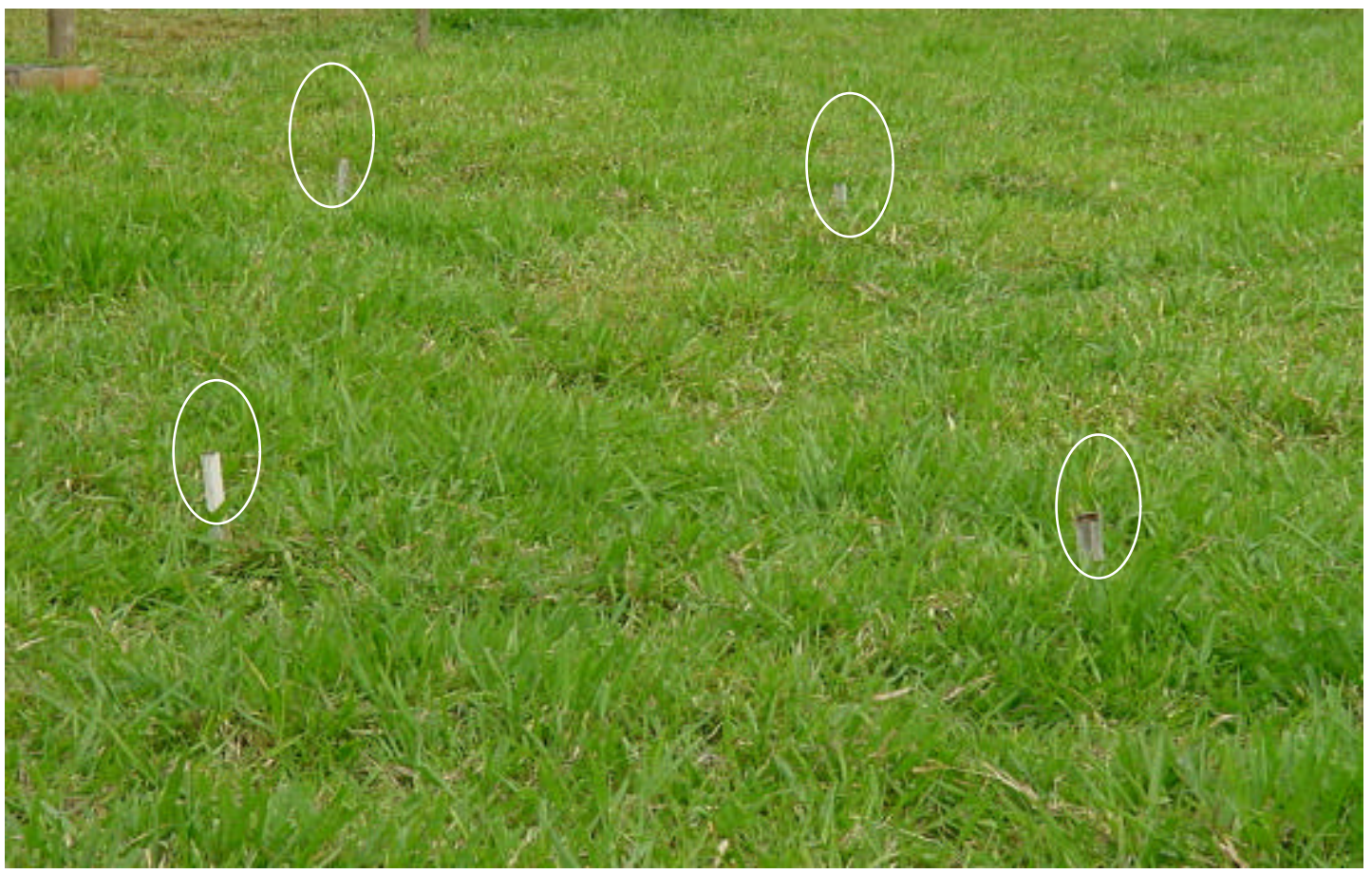

Figura 7 - Estacas para delimitação das réguas transectas

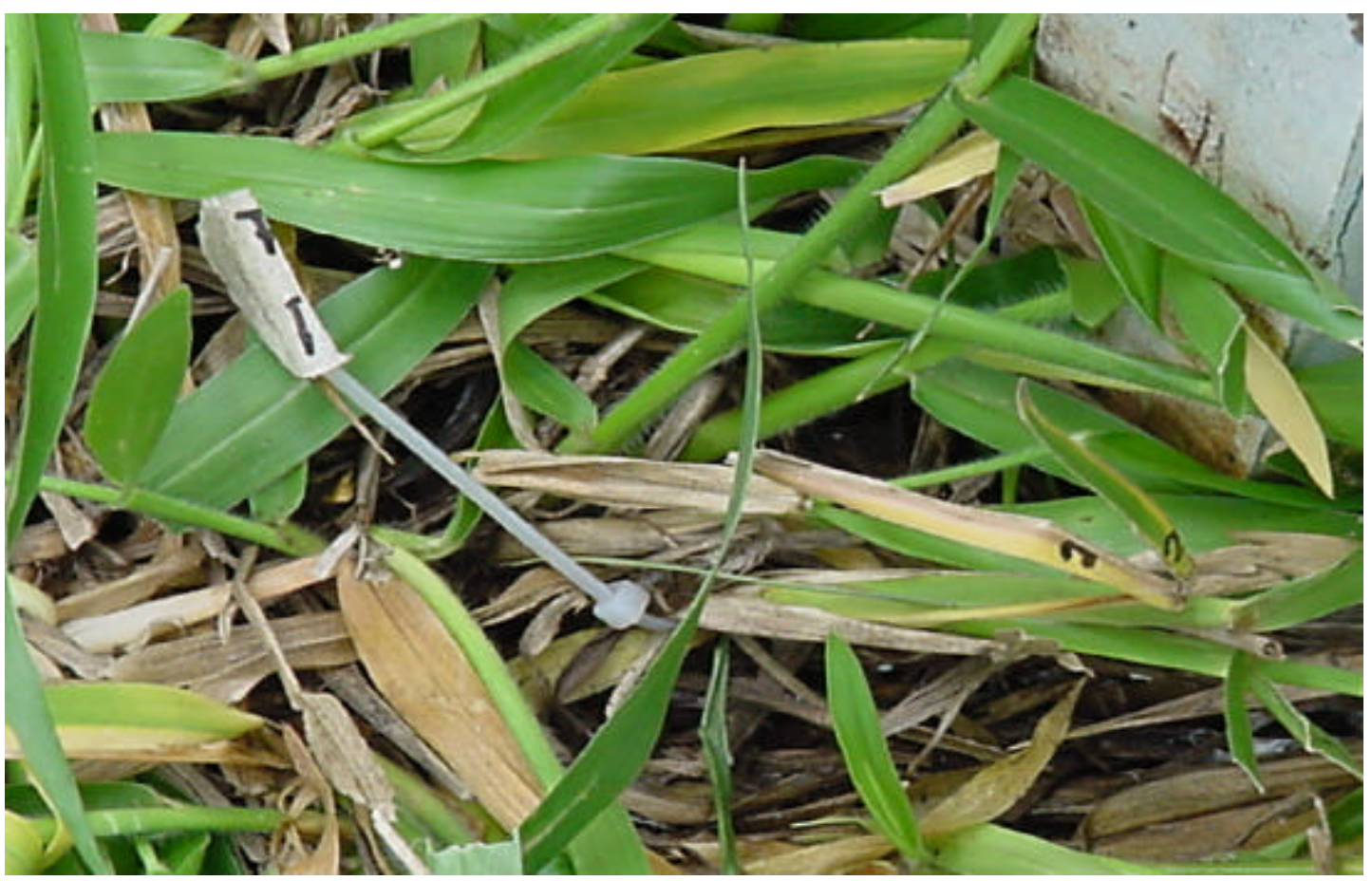

Figura 8 - Detalhe da marcação dos perfilhos 


\subsection{Medições realizadas nos perfilhos}

Em intervalos de tempo que variaram em função da época do ano (Tabela 3) foram anotadas diversas informações de cada um dos perfilhos selecionados.

Nessas ocasiões, os perfilhos passaram pelas seguintes avaliações: (a) medição do comprimento estendido (cm); (b) classificação como "intacto" ou "desfolhado"; (c) classificação como basal ou aéreo e (d) contagem do número de folhas. Cada uma das folhas desses perfilhos também foi avaliada com relação às seguintes características: (a) comprimento do limbo foliar, (b) classificada como intacta ou desfolhada e (c) classificada como folha em expansão, expandida, senescente e morta. As folhas e perfilhos eram considerados desfolhados quando parte deles estivesse cortada/decapitada. Folhas foram classificadas como em expansão quando suas lígulas não estavam expostas; expandidas quando a lígula estivesse visível e/ou seu crescimento cessasse (por vezes a lígula ficava internamente à bainha dificultando sua visualização); senescentes quando parte do limbo foliar apresentasse sinais de senescência; e mortas quando mais de $50 \%$ do limbo foliar estivesse comprometido pela senescência.

Tabela 3. Datas, número de avaliações e intervalo médio (em dias) entre as observações na avaliação de morfogênese e fluxo de tecidos.

\begin{tabular}{lcccc}
\hline \multicolumn{1}{c}{ Mês do ano } & Início & Término & $\begin{array}{c}\text { Número de } \\
\text { avaliações }\end{array}$ & $\begin{array}{c}\text { Intervalo médio } \\
\text { entre observações }\end{array}$ \\
Janeiro & $08 / 01 / 2002$ & $31 / 01 / 2002$ & 8 & 3 \\
Fevereiro & $05 / 02 / 2002$ & $25 / 02 / 2002$ & 7 & 3 \\
Março & $11 / 03 / 2002$ & $02 / 04 / 2002$ & 7 & 3 \\
Abril & $10 / 04 / 2002$ & $03 / 05 / 2002$ & 4 & 6 \\
Maio-Junho & $17 / 05 / 2002$ & $01 / 07 / 2002$ & 5 & 9 \\
Julho-Agosto & $15 / 07 / 2002$ & $02 / 09 / 2002$ & 5 & 10 \\
Setembro-Outubro & $20 / 09 / 2002$ & $29 / 10 / 2002$ & 4 & 10 \\
Novembro-Dezembro & $13 / 11 / 2002$ & $17 / 12 / 2002$ & 5 & 7 \\
\hline
\end{tabular}


O comprimento das folhas foi medido de acordo com o estádio de desenvolvimento das mesmas. Para as folhas expandidas, mediu-se o comprimento da ponta da folha até sua lígula. No caso de folhas em expansão, o mesmo procedimento era adotado, porém, considerando-se a lígula da última folha expandida como referencial de medida. Para as folhas em senescência, ao invés da ponta da folha, considerourse o ponto até onde o processo de senescência (amarelamento e enegrecimento) havia avançado (parte verde do limbo foliar). O tamanho da haste foi considerado como sendo a distância do solo (ou o ponto de inserção dessas, no caso de perfilhos aéreos) até a última lígula completamente expandida.

\subsubsection{Quantificação das variáveis}

Foram avaliados aspectos relativos à morfogênese das plantas (número de folhas maduras, em senescência e em expansão por perfilho; taxa de aparecimento, filocrono e longevidade de folhas) além das taxas de crescimento e senescência.

\subsection{Taxa de aparecimento de folhas e filocrono}

A taxa de aparecimento de folhas (TAF) indica o número de folhas que aparece por perfilho por unidade de tempo. A TAF foi calculada também com base na somatória calórica expressa em graus-dia (GD) (Ometto, 1981) e em unidade fototérmicas (UF) conforme equação desenvolvida por Villa Nova et al., (1983). Dessa forma, a TAF foi calculada conforme a eq. (1):

$\mathrm{TAF}=\mathrm{n}^{\circ}$ de novas folhas $/ \mathrm{n}^{\circ}$ de perfilhos $\mathrm{x}$ duração da avaliação (dias, GD e UF)

Para o cálculo em graus-dia, foi adotado um valor de $15{ }^{\circ} \mathrm{C}$ como temperatura basal. 
O filocrono corresponde ao inverso da TAF e seus valores foram calculados com base na eq. (2).

FILOCRONO $=1 / \mathrm{TAF}$

\subsection{Número de folhas vivas por perfilho}

Para obtenção do número de folhas vivas por perfilho (NFV), foi contabilizado o número médio de folhas em expansão, expandidas e em senescência de cada perfilho, desconsiderando-se as folhas onde o processo de senescência havia ultrapassado $50 \%$ do limbo foliar. O cálculo foi realizado a partir da eq. (3).

$\mathrm{NFV}=($ folhas em expansão + expandidas + senescentes $) / n^{\circ}$ perfilhos em avaliação

\subsection{Longevidade das folhas (LF)}

O período de vida das folhas foi calculado em dias e em graus-dia, considerandose o intervalo de tempo em dias e em graus-dia decorrido desde seu aparecimento até sua morte, respectivamente. Sua obtenção derivou da eq. (4).

$\mathrm{LF}=\mathrm{NFV} \times \mathrm{x}$ filocrono $(\mathrm{em}$ dias e GD)

\subsection{Taxas de crescimento, senescência e acúmulo líquido}

As variações em tamanho de cada folha e haste, a cada data de amostragem, possibilitaram o cálculo das taxas de crescimento e senescência. Variações positivas em tamanho possibilitaram o cálculo das taxas de crescimento ( $\mathrm{mm}$ perfilho ${ }^{-1}$ dia $^{-1}$ ), tanto para folhas como para hastes. No caso de diminuição da porção verde do limbo foliar 
(variações negativas em tamanho), ou seja, aumento na porção amarelada/parda das folhas, foi possível o cálculo das taxas de senescência de forma análoga ao crescimento. A diferença entre essas duas variáveis (crescimento e senescência) possibilitou a estimativa das taxas de acúmulo líquido. As diferenças no tamanho das folhas entre as medições (que não se enquadravam em alongamento da haste) foram classificadas como remoção de folhas, ou seja, qualquer redução no comprimento da folha provocada por algum agente externo (pastejo, insetos, pisoteio etc.).

Além disso, com o objetivo de permitir a expressão dos valores das taxas de crescimento, senescência, acúmulo líquido e remoção de forragem em $\mathrm{kg} \cdot \mathrm{ha}^{-1}$ de MS foi necessária a geração de um fator de conversão. Sempre no último dia de cada período de avaliação, todos os perfilhos marcados foram cortados no nível do solo, colocados em sacos plásticos e levados imediatamente à câmara fria para minimizar perdas por respiração e evaporação.

Após a medição de hastes e folhas de forma análoga àquela realizada no campo, todas as lâminas foliares de cada perfilho e suas respectivas hastes foram levadas para a estufa a $65^{\circ} \mathrm{C}$ por 48 horas. Após a secagem, o material foi pesado e a massa de cada componente dividida pelo comprimento total correspondente para cada régua transecta. Foi obtido assim um fator de conversão $\left(\mathrm{mg}_{\mathrm{mm}} \mathrm{m}^{-1}\right.$ ) utilizado para transformar todas as leituras de campo, expressas em mm.perfilho ${ }^{-1} \cdot \mathrm{dia}^{-1}$, em mg.perfilho-1 dia $^{-1}$. A transformação final para $\mathrm{kg} \cdot \mathrm{ha}^{-1} \cdot \mathrm{dia}^{-1}$ de MS foi realizada por meio da multiplicação desses valores pela densidade populacional média de perfilhos em cada unidade experimental (item 3.2.4.3.2). 


\subsubsection{Padrões demográficos de perfilhamento}

Para a avaliação da dinâmica populacional de perfilhos foram utilizados quatro anéis de PVC de $30 \mathrm{~cm}$ de diâmetro por unidade experimental, fixados ao solo por meio de grampos de arame (Figura 9).

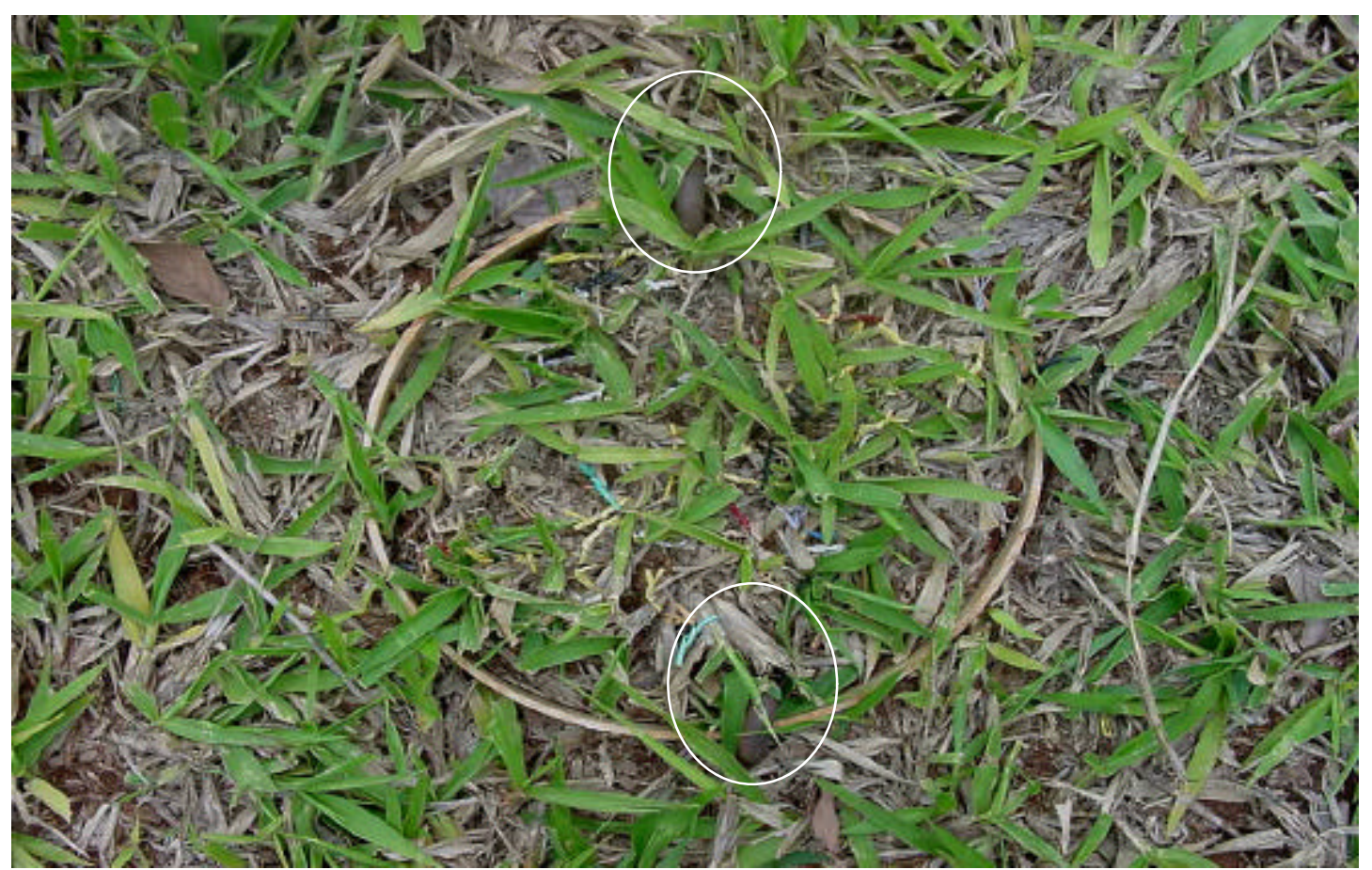

Figura 9 - Detalhe do anel de PVC usado na marcação dos perfilhos e dos grampos fixadores

A primeira marcação de perfilhos foi realizada em 21/11/2001, sendo que nessa data todos os perfilhos foram marcados com uma cor e denominados de $1^{\mathrm{a}}$ geração (G1). No mês seguinte (19/12/2001), os perfilhos já existentes nos anéis oriundos da G1 foram contados (somente os vivos) e os novos (que apareceram entre os períodos de amostragem) foram marcados com uma cor diferente. Estes foram então denominados como $2^{\mathrm{a}}$ geração (G2) e assim sucessivamente a cada mês de amostragem (Tabela 4). Dessa forma, os perfilhos pertencentes a todas as gerações avaliadas eram sempre recontados a cada nova avaliação e os novos perfilhos marcados com uma nova cor, 
originando uma nova geração (Figuras 10 e 11). O tempo gasto para cada avaliação foi de no máximo dois dias e o intervalo médio entre avaliações de quatro semanas. Como as avaliações não foram realizadas em intervalos de tempo rigorosamente iguais, todos os valores foram corrigidos para um período de 30 dias, utilizando-se interpolação linear simples.

Tabela 4. Datas das avaliações da demografia de perfilhamento, densidade populacional e características individuais de perfilhos.

\begin{tabular}{lccc}
\hline \multicolumn{1}{c}{ Mês do ano } & $\begin{array}{c}\text { Demografia do } \\
\text { perfilhamento }\end{array}$ & $\begin{array}{c}\text { Densidade } \\
\text { populacional }\end{array}$ & $\begin{array}{c}\text { Características } \\
\text { individuais }\end{array}$ \\
\hline Novembro (2001) & $21 / 11 / 2001$ & - & - \\
Dezembro (2001) & $19 / 12 / 2001$ & $22 / 12 / 2001$ & $20 / 12 / 2002$ \\
Janeiro & $17 / 01 / 2002$ & $23 / 01 / 2002$ & $17 / 01 / 2002$ \\
Fevereiro & $20 / 02 / 2002$ & $28 / 02 / 2002$ & $19 / 02 / 2002$ \\
Março & $21 / 03 / 2002$ & $30 / 03 / 2002$ & $26 / 03 / 2002$ \\
Abril & $20 / 04 / 2002$ & $30 / 04 / 2002$ & $24 / 04 / 2002$ \\
Maio & $26 / 05 / 2002$ & $28 / 05 / 2002$ & $25 / 05 / 2002$ \\
Junho & $26 / 06 / 2002$ & $26 / 06 / 2002$ & $20 / 06 / 2002$ \\
Julho & $24 / 07 / 2002$ & $29 / 07 / 2002$ & $22 / 07 / 2002$ \\
Agosto & $24 / 08 / 2002$ & $21 / 08 / 2002$ & $28 / 08 / 2002$ \\
Setembro & $24 / 09 / 2002$ & $22 / 09 / 2002$ & $18 / 09 / 2002$ \\
Outubro & $21 / 10 / 2002$ & $09 / 10 / 2002$ & $15 / 10 / 2002$ \\
Novembro & $22 / 11 / 2002$ & $19 / 11 / 2002$ & $30 / 11 / 2002$ \\
Dezembro & $16 / 12 / 2002$ & $11 / 12 / 2002$ & $16 / 12 / 2002$ \\
\hline
\end{tabular}




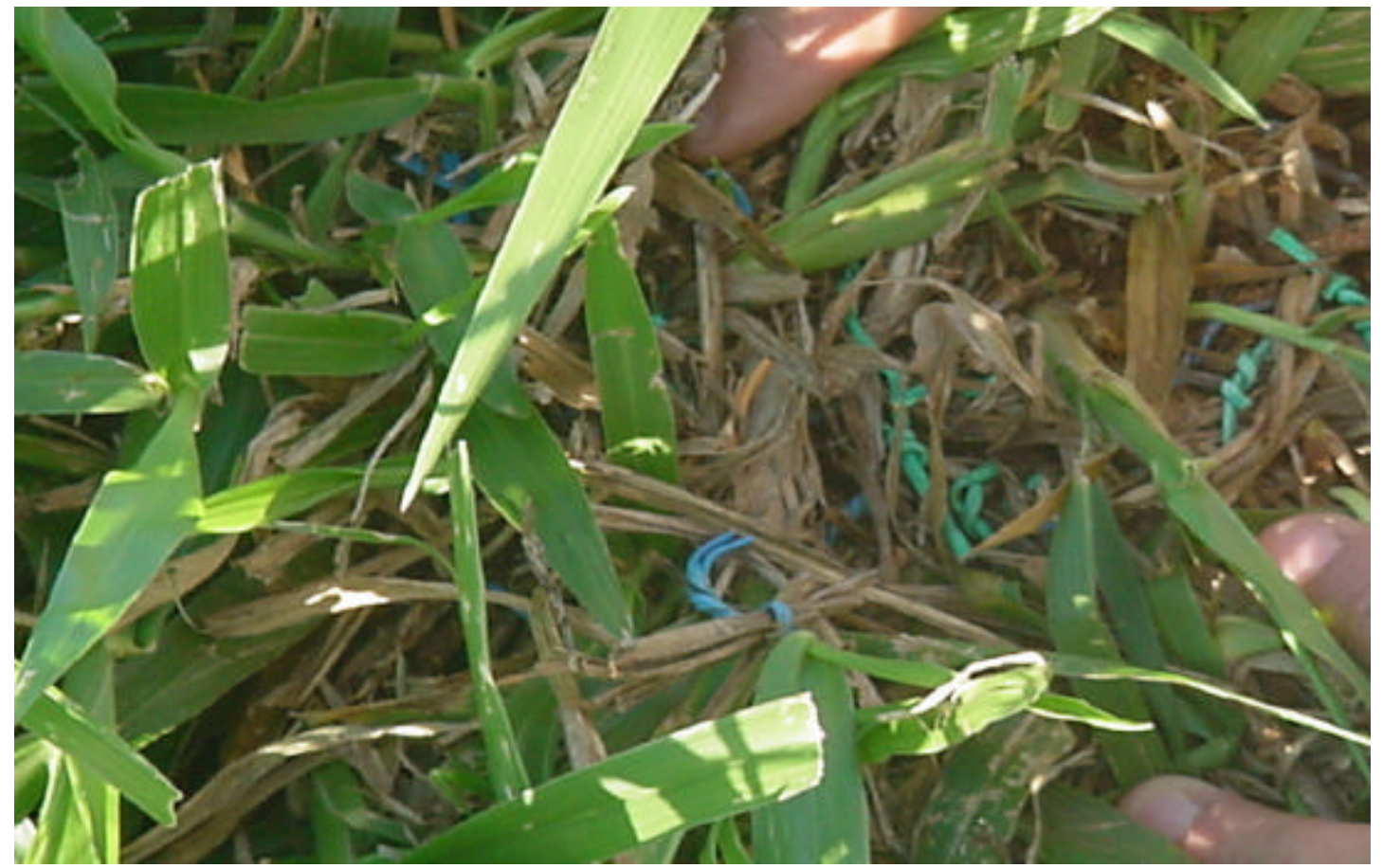

Figura 10 - Detalhe da marcação de perfilhos em dosséis de $40 \mathrm{~cm}$

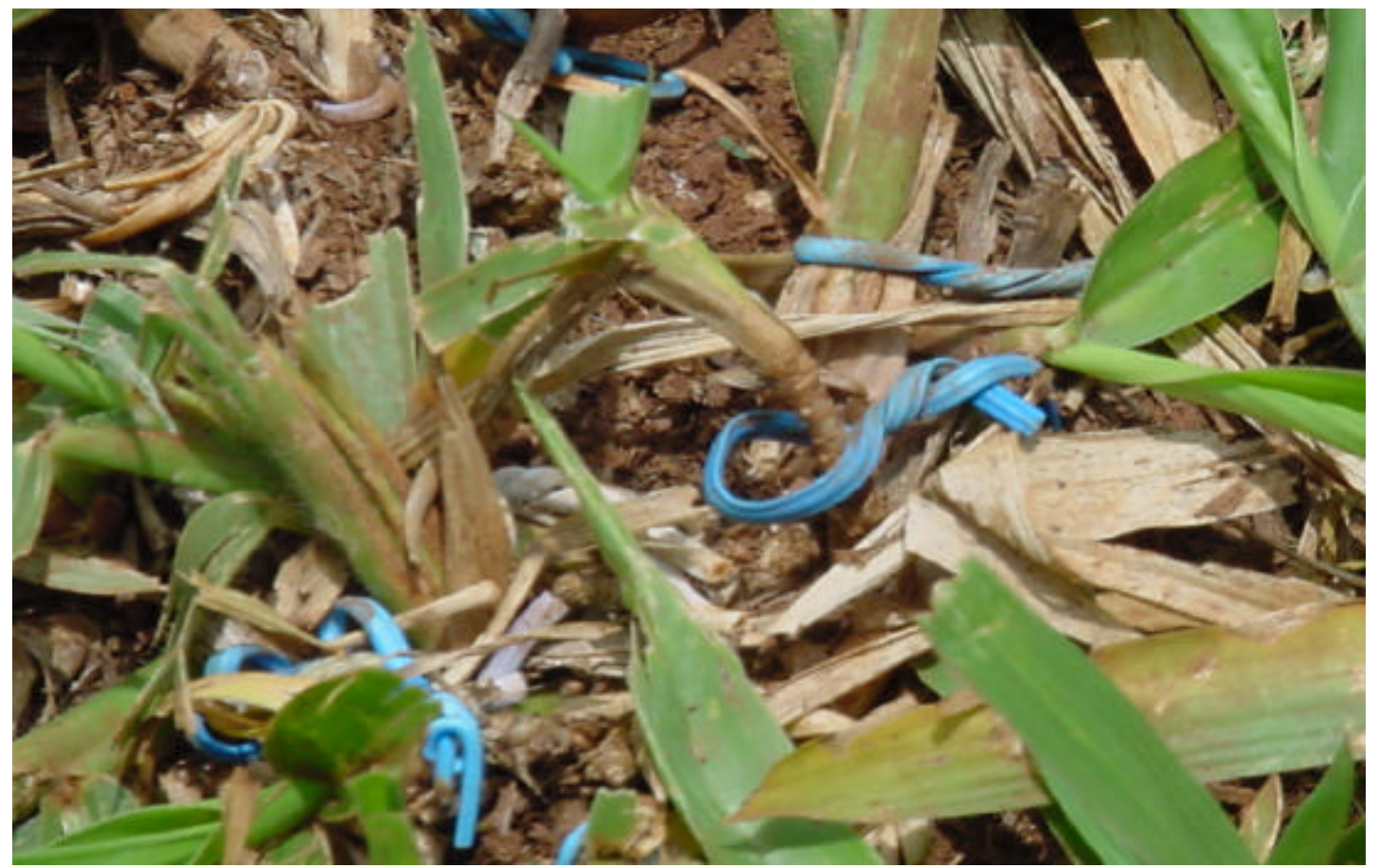

Figura 11 - Detalhe da marcação de perfilhos em dosséis de $10 \mathrm{~cm}$ 


\subsection{Taxas de aparecimento, mortalidade e sobrevivência de perfilhos}

As taxas de aparecimento de perfilhos, em cada mês, foram obtidas a partir da contagem dos novos perfilhos surgidos entre duas amostragens sucessivas, os quais eram marcados com um anel de cor diferente das já existentes. A partir desse ponto determinava-se qual a representação percentual destes no total de perfilhos existentes na amostragem anterior (considerando-se todas as gerações).

As taxas de sobrevivência de cada geração de perfilhos foram obtidas a partir da diferença entre a população existente num dado mês e a população existente no mês anterior, sendo os valores estimados em porcentagem. As taxas de mortalidade foram estimadas a partir das taxas de sobrevivência, as quais foram subtraídas de 100 .

\subsection{Densidade populacional de perfilhos}

As estimativas de densidade populacional de perfilhos foram obtidas independentemente daquelas de demografia do perfilhamento, devido a reduzida área do anel $\left(0,0707 \mathrm{~m}^{2}\right)$ e também para evitar que a manipulação periódica realizada em tais anéis (contagem mensais dos perfilhos) interferisse na estimativa final de densidade populacional.

Dessa forma, a contagem de perfilhos foi realizada em retângulos medindo 0,25 $\mathrm{m}^{2}$ de área $(100 \mathrm{~cm}$ x $25 \mathrm{~cm})$. A opção pelo uso de uma medida retangular foi a de englobar, dentro do possível, a grande heterogeneidade verificada em pastos de capimMarandu. As avaliações foram realizadas mensalmente (Tabela 4), e, para tanto, foram utilizados três retângulos por unidade experimental.

Além disso, durante cada procedimento de contagem de perfilhos, foram contabilizados aqueles perfilhos que tinham inflorescência visível, permitindo que a proporção deles pudesse ser calculada em relação à população total, em cada data de amostragem. 


\subsection{Diagramas de estabilidade}

Com o intuito de se observar conjuntamente os efeitos das taxas de aparecimento e sobrevivência de perfilhos na população do pastos, foram gerados diagramas sazonais de estabilidade. Essa técnica foi proposta por Sackville-Hamilton ${ }^{1}$ e colaboradores e utilizada parcialmente pela primeira vez por Bahmani et al. (2003) com azevém perene. Os índices de estabilidade foram calculados por meio da eq. (5).

$$
\frac{\mathrm{P}_{1}}{\mathrm{P}_{0}}=\mathrm{TSP}(1+\mathrm{TAP})
$$

onde;

$\frac{\mathrm{P}_{1}}{\mathrm{P}_{0}}=$ Proporção entre a população de perfilhos existente no mês (época) 1 e população existente no mês (época) 0 ;

TSP = Taxa de sobrevivência de perfilhos no mês (época) 1 ;

TAP $=$ Taxa de aparecimento de perfilhos no mês (época) 1 .

O desenvolvimento teórico da fórmula acima, foi concebida a partir das técnicas desenvolvidas por Leslie (1945) com álgebra de matrizes para o estudo de dinâmica de populações. Basicamente, se o índice de estabilidade for menor que 1, significa que os pastos têm uma taxa de aparecimento relativa menor que as taxas de sobrevivência para um mesmo período de tempo, indicando instabilidade da população de plantas na área.

\subsubsection{Avaliações de características individuais dos perfilhos}

Diversas características individuais dos perfilhos foram avaliadas e, para tanto, foram coletados aleatoriamente 60 perfilhos em cada unidade experimental, de dezembro de 2001 a dezembro de 2002 (Tabela 3). Todos os perfilhos colhidos foram

\footnotetext{
${ }^{1}$ Informação pessoal. Trabalho não publicado.
} 
acondicionados em sacos plásticos e rapidamente levados à câmara fria para resfriamento $\left(4^{\circ} \mathrm{C}\right)$ e minimização dos efeitos de respiração e transpiração das plantas, sendo posteriormente processados.

\subsection{Massa de folhas, massa média e área foliar média por perfilho}

Inicialmente os 60 perfilhos coletados foram pesados em balança digital de tal forma que os valores obtidos, divididos pelos mesmos 60 perfilhos, resultaram na massa fresca média por perfilho. Após a pesagem, foram separados, de cada perfilho, suas lâminas verdes, material morto e haste. As lâminas verdes tiveram sua área foliar medida em aparelho integrador de área foliar, marca LICOR, modelo LI-3100. Posteriormente, cada componente foi acondicionado em saquinhos de papel e levados para estufa a $65^{\circ} \mathrm{C}$ por 48 horas. Após a secagem foram pesados em balança digital.

\subsubsection{2 Área foliar específica}

A área foliar específica $\left(\mathrm{cm}^{2} \cdot \mathrm{g}^{-1}\right)$ fi obtida a partir do quociente entre a área foliar e a massa seca de folhas por perfilho.

\subsection{Relação folha: haste e razão área foliar: volume por perfilho (R)}

A relação folha: haste $(\mathrm{FH})$ foi obtida a partir do quociente entre a massa seca de folhas e a massa seca de hastes. Durante o período de verão e outono o componente material morto não foi separado dos demais, de tal forma que no componente haste ficaram contidos os tecidos mortos. A razão área foliar: volume por perfilho (R) foi proposta por Sackville-Hamilton et al. (1995) e corresponde a uma medida adimensional já que a área foliar é elevada a potência de 3/2 durante seu cálculo (eq. (6)). 
$\mathrm{R}=\frac{\mathrm{A}_{\mathrm{f}}^{3 / 2}}{\mathrm{~V}}$ onde;

$\mathrm{R}$ = razão área foliar: volume por perfilho;

$\mathrm{A}_{\mathrm{f}}=$ área foliar média por perfilho $\left(\mathrm{m}^{2}\right)$;

$\mathrm{V}=$ volume médio por perfilho $\left(\mathrm{m}^{3}\right)$.

Essa razão foi calculada de duas maneiras. Na primeira delas assumiutse uma densidade aparente dos perfilhos constante de $950 \mathrm{~kg} \cdot \mathrm{m}^{-3}$ (Sbrissia et al., 2001; 2003), e a partir desse valor e a da massa verde por perfilho, foram obtidos os volumes que entraram no cálculo dessa variável. A outra maneira foi usando-se os volumes originalmente medidos com o instrumento construído para tal finalidade (item 3.2.4.4.5). Como as medições de volume foram consistentes apenas a partir de julho, essa última forma de cálculo só foi possível para as épocas de inverno e início e final de primavera.

\subsubsection{4 Índice de área foliar (IAF)}

O índice de área foliar do dossel foi calculado a partir da eq. (7):

$\mathrm{IAF}=\mathrm{DPP} \times \mathrm{A}_{\mathrm{f}}$ onde;

$\mathrm{DPP}=$ densidade populacional de perfilhos $\left(\mathrm{n}^{\circ}\right.$ de perfilhos por metro quadrado), $\mathrm{e}$ $\mathrm{A}_{\mathrm{f}}=$ área foliar média por perfilho (em metros quadrados). 


\subsection{Volume $\left(\mathrm{m}^{3}\right)$ e densidade aparente média $\left(\mathrm{kg}\right.$ massa verde. $\left.\mathrm{m}^{-3}\right)$}

A estimativa do volume médio por perfilho foi realizada por meio da técnica do deslocamento de líquido. Para tanto, foi construído um equipamento baseado no princípio de vasos comunicantes (Figura 12). O equipamento em questão era composto de um tubo de PVC de $15 \mathrm{~cm}$ de diâmetro ligado por uma borracha de tubulação de gás residencial a uma pipeta volumétrica laboratorial.

Durante os primeiros sete meses de avaliação (de dezembro de 2001 a junho de 2002) o procedimento adotado consistiu na imersão dos 60 perfilhos coletados no tubo de PVC, previamente preenchido com água até uma marca delimitada na pipeta a qual se encontrava ligado. Pelo simples princípio de deslocamento de líquido fazia-se a leitura do volume de água deslocado pelos perfilhos com o auxílio de uma régua. No entanto, em discussões freqüentes com a equipe de trabalho, foi levantada a possibilidade de que os perfilhos, quando imersos na água, poderiam estar carregando bolhas de ar, o que poderia causar uma superestimativa no valor do volume e uma conseqüente subestimativa nos cálculos de densidade aparente (obtida a partir do quociente entre a massa verde (item 3.2.4.4.1) e o volume medido). Dessa forma, com o intuito de aprimorar a metodologia, foi construído um novo aparelho, de princípio idêntico ao anterior sendo que a única diferença foi o diâmetro do tubo de $\mathrm{PVC}$, de 7,5 cm. O objetivo de tal procedimento foi o de permitir uma variação maior no deslocamento de água, possibilitando uma leitura mais acurada. Além disso, bi usado um óleo mineral parafínico (nome comercial: Assist ${ }^{\circledR}$, empresa $\mathrm{BASF}^{\circledR}$ ) na proporção de $1 \%$, com o objetivo de reduzir a formação de bolhas. Além disso, o fato do diâmetro do tubo de PVC ser menor que o anterior permitiu que fossem avaliados, de maneira independente, os volumes de folha, haste e material morto. Os resultados obtidos apresentaram maior consistência que o método anterior, já que os valores absolutos das medidas de densidade aparente foram mais próximos daqueles obtidos em avaliações semelhantes, porém com métodos diferentes (Matthew et al., 1995, Sbrissia et al., 2001). 


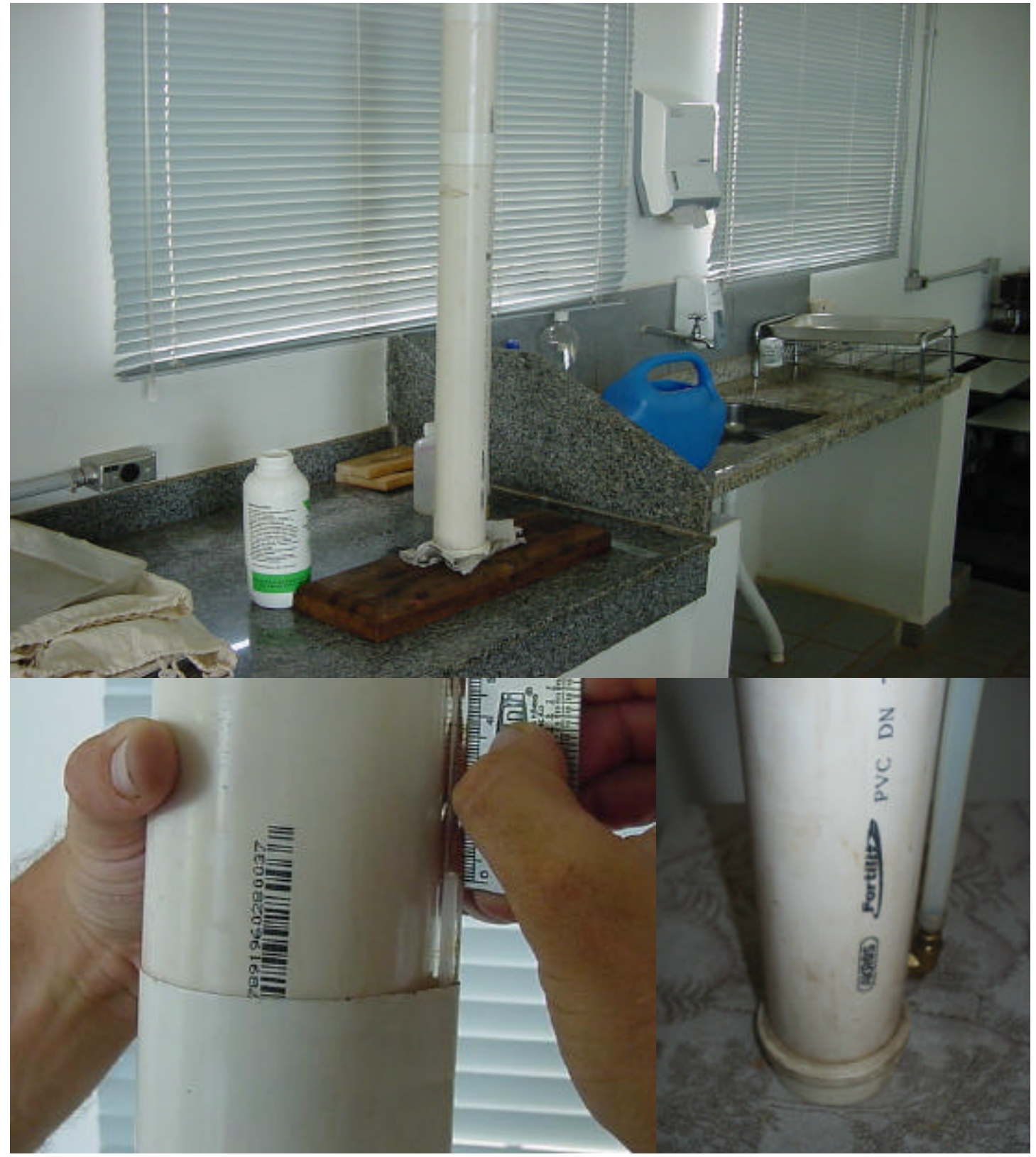

Figura 12 - Detalhe do equipamento utilizado para medições de volume 


\subsubsection{Processamento dos dados e análise estatística}

Os resultados foram agrupados de acordo com as épocas do ano. Após análise visual e identificação de períodos com padrão homogêneo de comportamento das variáveis estudadas, optou-se por agrupar os meses da seguinte forma:

Verão: Janeiro, Fevereiro e Março;

Outono: Abril, Maio e Junho;

Inverno: Julho e Agosto;

Início de Primavera: Setembro e Outubro;

Final de Primavera: Novembro e Dezembro.

A opção pelo agrupamento dos dados de dois em dois meses a partir de julho foi com o objetivo de isolar os meses de setembro e outubro num período único. Nesses dois meses os pastos apresentaram padrões de resposta excepcionalmente diferentes dos demais, mas semelhantes entre si. Como houve mudança na metodologia de avaliação do volume dos perfilhos durante o experimento, os dados de volume, densidade aparente e razão área foliar: volume por perfilho foram analisados somente para os períodos de inverno e início e final de primavera.

Os dados assim agrupados foram analisados utilizando-se o procedimento MIXED (modelos mistos) do pacote estatístico SAS ${ }^{\circledR}$ (Statistical Analysis System) versão 8.2 para Windows ${ }^{\circledR}$. A opção pelo uso do procedimento MIXED foi devido à natureza de medidas repetidas dos dados (coletados seqüencialmente no tempo), uma vez que tal procedimento permite maior flexibilidade no sentido de modelar as estruturas de covariância. Nesse sentido, o procedimento MIXED fornece uma rica classificação de tipos de matrizes de covariância para serem selecionadas, diferentemente do outro procedimento (GLM - modelos lineares generalizados) comumente usado em análises dessa natureza (SAS Institute, 2004). Dessa forma, foi possível detectar os efeitos das causas de variação principais (altura e época do ano), bem como a interação entre elas. 
Os efeitos de altura do dossel e época do ano e suas interações foram considerados fixos e o efeito de bloco foi considerado aleatório (Littel et al., 2000).

Cabe ressaltar que todos os conjuntos de dados foram testados, antes da análise geral global, com a finalidade de assegurar que as quatro prerrogativas básicas da análise de variância (aditividade do modelo, independência dos erros, normalidade dos dados e homogeneidade de variâncias) estavam sendo respeitadas. Para efeito de comparação de médias entre tratamentos foi utilizado o "LSMEANS", com um nível de significância de $10 \%$.

No caso das regressões lineares usadas nos cálculos dos parâmetros da compensação tamanho/densidade populacional de perfilhos, foi usado o programa PAST $^{\circledR}$, uma vez que o mesmo calcula os coeficientes angulares das regressões pelo método do "eixo maior reduzido" (do inglês, Reduced Major Axis, ou RMA). Esse procedimento é particularmente preferido nesse caso (Sackville-Hamilton et al., 1995), onde ocorre erro amostral nos dois eixos (LaBarbera, 1989).

Com o objetivo de se obter uma interpretação sistêmica dos dados utilizou-se procedimentos de análise multivariada. A análise de componentes principais (ACP) foi realizada utilizando-se o programa MINITAB, versão 14 para Windows ${ }^{\circledR}$ e teve por finalidade testar a possibilidade de se reduzir o número de variáveis explicativas em alguns poucos componentes. Para tanto, duas ACP foram realizadas. Na primeira foram consideradas as seguintes variáveis: densidade populacional de perfilhos (DPP), massa por perfilho (MP), índice de área foliar (IAF), razão área foliar: volume por perfilhos (R), relação folha: haste (FH), taxa de aparecimento de perfilhos (TAP) e taxa de sobrevivência de perfilhos (TSP). O objetivo dessa análise foi $\mathrm{o}$ de analisar conjuntamente os dados que envolvem a compensação tamanho/densidade populacional de perfilhos e aqueles relativos à dinâmica do perfilhamento. Já a segunda análise foi realizada com as seguintes variáveis: densidade populacional de perfilhos (DPP), longevidade de folhas (LF), área foliar específica (AFE), taxa de alongamento de folhas (TAlF) e taxa de senescência de folhas (TSF), sendo que seu objetivo foi o de analisar de forma integrada alguns dados de morfogênese e de dinâmica do acúmulo. 


\section{RESULTADOS}

\subsection{Características morfogênicas}

\subsubsection{Número de folhas em expansão, senescentes e vivas por perfilho}

Houve efeito de altura do dossel $(\mathrm{P}=0,0097)$ e época do ano $(\mathrm{P}<0,0001)$ sobre o número de folhas em expansão por perfilho (NFE).

Tabela 5. Número de folhas em expansão por perfilho em pastos de capim-Marandu mantidos em quatro alturas de dossel forrageiro por meio de lotação contínua em diferentes épocas do ano

\begin{tabular}{|c|c|c|c|c|c|c|c|c|c|c|c|}
\hline \multirow{3}{*}{$\begin{array}{c}\text { Epoca do } \\
\text { ano } \\
\text { Verão }\end{array}$} & \multicolumn{8}{|c|}{ Altura $(\mathrm{cm})$} & \multirow{2}{*}{\multicolumn{2}{|c|}{ Média }} & \multirow{2}{*}{ EPM* } \\
\hline & \multicolumn{2}{|c|}{10} & \multicolumn{2}{|c|}{20} & \multicolumn{2}{|c|}{30} & \multicolumn{2}{|c|}{40} & & & \\
\hline & 1,4 & a B & 1,4 & a B & 1,4 & a B & 1,4 & a B & 1,4 & $\mathrm{C}$ & 0,03 \\
\hline Outono & 1,7 & a A & 1,4 & $\mathrm{~b} \mathrm{~B}$ & 1,4 & b B & 1,3 & b BC & 1,5 & $\mathrm{BC}$ & 0,03 \\
\hline Inverno & 1,6 & a A & 1,5 & $\mathrm{bB}$ & 1,5 & b B & 1,4 & b B & 1,5 & B & 0,03 \\
\hline Ini. Prim. & 1,3 & a C & 1,1 & $\mathrm{bC}$ & 1,2 & $\mathrm{ab} \mathrm{C}$ & 1,2 & ab C & 1,2 & D & 0,03 \\
\hline Fin. Prim. & 1,8 & a A & 1,8 & a A & 1,7 & a A & 1,8 & a A & 1,8 & A & 0,03 \\
\hline Média & 1,5 & a & 1,4 & $\mathrm{~b}$ & 1,4 & $\mathrm{~b}$ & 1,4 & $\mathrm{~b}$ & & & \\
\hline $\mathrm{EPM}^{\dagger}$ & 0,01 & & 0,01 & & 0,01 & & 0,01 & & & & \\
\hline
\end{tabular}

"Erro padrão da média

Erro padrão da média da interação $=0,06$

Médias seguidas da mesma letra minúscula na linha e maiúscula na coluna não diferem entre si $(\mathrm{P}>0,10)$

† As médias das alturas correspondem à média de todos os meses do experimento 
Para as épocas de verão e início e final de primavera os valores de NFE foram praticamente constantes para as alturas de dossel estudadas. No outono e inverno os pastos mantidos a $10 \mathrm{~cm}$ apresentaram os maiores valores de NFE em relação àqueles mantidos a 20, 30 e $40 \mathrm{~cm}$, os quais não diferiram entre si. Esse padrão de outonoinverno determinou as respostas dessa variável na média do período experimental (Tabela 5). Em relação às épocas do ano, os valores permaneceram relativamente constantes durante o verão, outono e o inverno, sofrendo redução no início da primavera e aumentando ao final dessa estação.

Para o número de folhas senescentes por perfilho (NFS), houve efeito de altura do dossel $(\mathrm{P}=0,0007)$ e época do ano $(\mathrm{P}<0,0001)$, além da interação altura do dossel $\mathrm{x}$ época do ano $(\mathrm{P}<0,0001)$. O NFS foi maior em dosséis mantidos mais altos $(30$ e $40 \mathrm{~cm})$ (Tabela 6). Em relação às épocas do ano, o NFS foi aumentando ao longo das estações a partir do início do experimento, sendo o valor do NFS cerca de 3,7 vezes superior no início da primavera em relação ao verão.

Tabela 6. Número de folhas senescentes por perfilho em pastos de capim-Marandu mantidos em quatro alturas de dossel forrageiro por meio de lotação contínua em diferentes épocas do ano

\begin{tabular}{|c|c|c|c|c|c|c|c|c|c|c|c|}
\hline \multirow{2}{*}{$\begin{array}{c}\text { Época do } \\
\text { ano }\end{array}$} & \multicolumn{8}{|c|}{ Altura $(\mathrm{cm})$} & \multirow{2}{*}{\multicolumn{2}{|c|}{ Média }} & \multirow{2}{*}{ EPM" } \\
\hline & \multicolumn{2}{|c|}{10} & \multicolumn{2}{|c|}{20} & \multicolumn{2}{|c|}{30} & \multicolumn{2}{|c|}{40} & & & \\
\hline Verão & 0,3 & $b c$ & 0,3 & $b c$ & 0,4 & $\mathrm{aD}$ & 0,3 & $\mathrm{abD}$ & 0,3 & $\mathrm{E}$ & 0,03 \\
\hline Outono & 0,6 & $\mathrm{ab} \mathrm{AB}$ & 0,5 & b B & 0,7 & $\mathrm{a} \mathrm{C}$ & 0,7 & a $\mathrm{C}$ & 0,6 & D & 0,03 \\
\hline Inverno & 0,7 & b A & 0,7 & b A & 1,0 & a B & 0,8 & $\mathrm{ab} \mathrm{C}$ & 0,8 & C & 0,03 \\
\hline Ini. Prim. & 0,5 & c B & 0,8 & $\mathrm{~b} A$ & 1,2 & a A & 1,2 & a B & 0,9 & B & 0,03 \\
\hline Fin. Prim. & 0,8 & $\mathrm{~b} A$ & 0,9 & $\mathrm{~b}$ A & 1,0 & b B & 1,7 & $\mathrm{a} A$ & 1,1 & A & 0,03 \\
\hline Média $^{\dagger}$ & 0,5 & $\mathrm{~b}$ & 0,5 & $\mathrm{~b}$ & 0,7 & a & 0,7 & $\mathrm{a}$ & & & \\
\hline EPM & 0,03 & & 0,03 & & 0,03 & & 0,03 & & & & \\
\hline
\end{tabular}

Erro padrão da média

Erro padrão da média da interação $=0,071$

Médias seguidas da mesma letra minúscula na linha e maiúscula na coluna não diferem entre si $(\mathrm{P}>0,10)$

† As médias das alturas correspondem à média de todos os meses do experimento 
Com relação ao número de folhas vivas por perfilho (NFV), houve efeito de altura do dossel $(\mathrm{P}=0,0037)$ e época do ano $(\mathrm{P}<0,0001)$, além da interação altura do dossel $\mathrm{x}$ época do ano $(\mathrm{P}<0,0001)$. Dosséis mantidos mais altos $(30$ e $40 \mathrm{~cm}$ ) apresentaram os maiores valores de NFV (4,6 folhas vivas/perfilho), enquanto que dosséis mantidos a 10 e $20 \mathrm{~cm}$ de altura apresentaram os valores mais baixos (4,2 folhas vivas/perfilho) (Tabela 7). Ao longo do ano, a principal diferença foi entre o início e o final da primavera, sendo o valor desse último $25 \%$ superior ao do período anterior.

Tabela 7. Número de folhas vivas por perfilho em pastos de capim-Marandu mantidos em quatro alturas de dossel forrageiro por meio de lotação contínua em diferentes épocas do ano

\begin{tabular}{|c|c|c|c|c|c|c|c|c|c|c|c|}
\hline \multirow{2}{*}{$\begin{array}{c}\text { Epoca do } \\
\text { ano }\end{array}$} & \multicolumn{8}{|c|}{ Altura $(\mathrm{cm})$} & \multirow{2}{*}{\multicolumn{2}{|c|}{ Média }} & \multirow{2}{*}{$\mathrm{EPM}^{*}$} \\
\hline & 10 & & 20 & & 30 & & 40 & & & & \\
\hline Verão & 3,8 & $\mathrm{bB}$ & 4,4 & $\mathrm{a} A$ & 4,5 & $\mathrm{a} B C$ & 4,6 & $\mathrm{aB}$ & 4,3 & c & 0,08 \\
\hline Outono & 4,5 & $\mathrm{abA}$ & 4,3 & $\mathrm{~b} A$ & 4,7 & a B & 4,5 & ab B & 4,5 & B & 0,08 \\
\hline Inverno & 4,5 & a A & 4,2 & ab A & 4,3 & ab C & 4,0 & $\mathrm{bC}$ & 4,2 & C & 0,08 \\
\hline Ini. Prim. & 3,7 & b B & 3,8 & b B & 4,2 & a C & 4,3 & a $\mathrm{BC}$ & 4,0 & D & 0,08 \\
\hline Fin. Prim. & 4,6 & $\mathrm{~b}$ A & 4,5 & b A & 5,4 & a A & 5,6 & a A & 5,0 & A & 0,08 \\
\hline Média $^{\dagger}$ & 4,2 & $\mathrm{~b}$ & 4,3 & $\mathrm{~b}$ & 4,6 & $\mathrm{a}$ & 4,6 & $\mathrm{a}$ & & & \\
\hline $\mathrm{EPM}^{*}$ & 0,05 & & 0,05 & & 0,05 & & 0,05 & & & & \\
\hline
\end{tabular}

"Erro padrão da média

Erro padrão da média da interação $=0,16$

Médias seguidas da mesma letra minúscula na linha e maiúscula na coluna não diferem entre si $(\mathrm{P}>0,10)$

${ }^{\dagger}$ As médias das alturas correspondem à média de todos os meses do experimento

\subsubsection{Taxa de aparecimento, filocrono e longevidade de folhas por perfilho}

A taxa de aparecimento de folhas (folhas.perfilho ${ }^{-1} \cdot \mathrm{dia}^{-1}$ ) (TAF) foi decrescente com o aumento em altura do dossel forrageiro. Houve efeito de altura do dossel $(\mathrm{P}<0,0001)$, época do ano $(\mathrm{P}<0,0001)$ e interação altura do dossel $\mathrm{x}$ época do ano $(\mathrm{P}=0,0283)$. Os valores mais altos foram registrados nos dosséis mantidos mais baixos 
$(10 \mathrm{~cm})$, onde foram verificadas TAF de 0,077 folha.perfilho ${ }^{-1} \cdot \mathrm{dia}^{-1}$, contrastando com dosséis mantidos a $40 \mathrm{~cm}$ de altura, onde a TAF foi de 0,052 folha.perfilho ${ }^{-1} \cdot \mathrm{dia}^{-1}$. Em relação às épocas do ano, os maiores valores de TAF foram registrados durante o período de final de primavera e verão, sendo esses cerca de 4,5 vezes superiores àqueles registrados durante o período de início de primavera (Tabela 8).

Tabela 8. Taxa de aparecimento de folhas (folhas.perfilho ${ }^{-1} \cdot \mathrm{dia}^{-1}$ ) em pastos de capimMarandu mantidos em quatro alturas de dossel forrageiro por meio de lotação contínua em diferentes épocas do ano

\begin{tabular}{cccccccccccc}
\hline $\begin{array}{c}\text { Epoca do } \\
\text { ano }\end{array}$ & \multicolumn{9}{c}{10} & & \multicolumn{9}{c}{20} & \multicolumn{2}{c}{30} & & & & & Média & \multirow{2}{*}{ EPM $^{*}$} \\
\hline Verão & 0,103 & a A & 0,091 & b A & 0,087 & b A & 0,075 & c B & 0,089 & A & 0,0014 \\
Outono & 0,068 & a B & 0,051 & b C & 0,048 & b B & 0,032 & c C & 0,050 & B & 0,0014 \\
Inverno & 0,047 & a C & 0,035 & b D & 0,034 & b C & 0,026 & c C & 0,035 & C & 0,0014 \\
Ini. Prim. & 0,027 & a D & 0,015 & b E & 0,016 & b D & 0,017 & b D & 0,019 & D & 0,0014 \\
Fin. Prim. & 0,100 & a A & 0,084 & b B & 0,084 & b A & 0,082 & b A & 0,088 & A & 0,0014 \\
Média $^{\dagger}$ & 0,077 & a & 0,063 & b & 0,061 & b & 0,052 & c & & & \\
EPM $^{*}$ & 0,0010 & & 0,00095 & 0,00095 & 0,00095 & & & & \\
\hline
\end{tabular}

Erro padrão da média

Erro padrão da média da interação $=0,0028$

Médias seguidas da mesma letra minúscula na linha e maiúscula na coluna não diferem entre si $(\mathrm{P}>0,10)$

$\dagger$ As médias das alturas correspondem à média de todos os meses do experimento

Para as taxas de aparecimento de folhas em graus-dia (TAFG), houve efeito de altura do dossel $(\mathrm{P}<0,0001)$, época do ano $(\mathrm{P}<0,0001)$ e interação altura do dossel $\mathrm{x}$ época do ano $(\mathrm{P}=0,0005)$. $\mathrm{O}$ padrão de resposta observado foi semelhante àquele verificado para a TAF, sendo os valores mais altos registrados nos dosséis mantidos mais baixos (Tabela 9) e durante o período de final de primavera e verão, em contraste com os menores valores registrados durante o período de início de primavera. 
Tabela 9. Taxa de aparecimento de folhas (folhas.perfilho ${ }^{-1}$.graus- dia $^{-1}$ ) em pastos de capim-Marandu mantidos em quatro alturas de dossel forrageiro por meio de lotação contínua em diferentes épocas do ano

\begin{tabular}{|c|c|c|c|c|c|c|c|c|c|c|c|}
\hline \multirow{2}{*}{$\begin{array}{c}\text { Época do } \\
\text { ano }\end{array}$} & \multicolumn{8}{|c|}{ Altura $(\mathrm{cm})$} & \multirow{2}{*}{\multicolumn{2}{|c|}{ Média }} & \multirow{2}{*}{$\mathrm{EPM}^{*}$} \\
\hline & \multicolumn{2}{|l|}{10} & \multicolumn{2}{|l|}{20} & \multicolumn{2}{|l|}{30} & 40 & & & & \\
\hline Verão & 0,0102 & $\mathrm{a} A \mathrm{~B}$ & 0,0100 & $\mathrm{bA}$ & 0,0090 & $\mathrm{bA}$ & 0,0080 & cA & 0,0092 & & 0,00014 \\
\hline Outono & 0,0110 & a A & 0,0073 & $\mathrm{~b} B \mathrm{BC}$ & 0,0068 & b BC & 0,0048 & c B & 0,0074 & C & 0,00034 \\
\hline Inverno & 0,0088 & $\mathrm{aC}$ & 0,0063 & $\mathrm{bC}$ & 0,0060 & $\mathrm{bC}$ & 0,0045 & c B & 0,0064 & D & 0,00021 \\
\hline Ini. Prim. & 0,0030 & $\mathrm{aD}$ & 0,0017 & $\mathrm{bD}$ & 0,0018 & bD & 0,0018 & $\mathrm{bC}$ & 0,0021 & E & 0,00013 \\
\hline Fin. Prim. & 0,0100 & $\mathrm{aBC}$ & 0,0083 & b B & 0,0078 & b B & 0,0078 & b A & 0,0083 & B & 0,00022 \\
\hline Média $^{\dagger}$ & 0,0074 & $\mathrm{a}$ & 0,0062 & $\mathrm{~b}$ & 0,0059 & D & 0,0051 & $\mathrm{c}$ & & & \\
\hline $\mathrm{EPM}^{*}$ & 0,0000 & & 0,000 & & 0,000 & & 0,000 & & & & \\
\hline
\end{tabular}

Erro padrão da média

Erro padrão da média da interação: Verão=0,00028, Outono=0,00068, Inverno=0,00042, Ini. Prim.=0,00026, Fin. Prim.=0,00044

Médias seguidas da mesma letra minúscula na linha e maiúscula na coluna não diferem entre si $(\mathrm{P}>0,10)$

${ }^{\dagger}$ As médias das alturas correspondem à média de todos os meses do experimento

Com relação ao filocrono expresso em dias, houve efeito de altura do dossel $(\mathrm{P}=0,0003)$, época do ano $(\mathrm{P}<0,0001)$ e interação altura do dossel $\mathrm{x}$ época do ano $(\mathrm{P}<0,0001)$. $\mathrm{O}$ maior valor de filocrono foi verificado para dosséis mantidos mais altos $(40 \mathrm{~cm})$, para os quais foram necessários, em média, 28 dias para o aparecimento de uma folha, contrastando com os 16,5 dias em dosséis mantidos a $10 \mathrm{~cm}$ de altura (Tabela 10). Não houve diferenças entre os períodos de final de primavera e verão, épocas em que foram necessários cerca de 12 dias para o aparecimento de uma folha. Já durante o início da primavera foram necessários cerca de 57 dias. 
Tabela 10. Filocrono (dias.folha ${ }^{-1}$ ) em perfilhos de capim-Marandu mantidos em quatro alturas de dossel por meio delotação contínua em diferentes épocas do ano

\begin{tabular}{|c|c|c|c|c|c|c|c|c|c|c|c|}
\hline \multirow{2}{*}{$\begin{array}{c}\text { Epoca do } \\
\text { ano }\end{array}$} & \multicolumn{8}{|c|}{ Altura $(\mathrm{cm})$} & \multirow{2}{*}{\multicolumn{2}{|c|}{ Média }} & \multirow{2}{*}{ EPM } \\
\hline & \multicolumn{2}{|c|}{10} & \multicolumn{2}{|c|}{20} & \multicolumn{2}{|c|}{30} & \multicolumn{2}{|c|}{40} & & & \\
\hline Verão & 10,2 & $\mathrm{CD}$ & 11,2 & $\mathrm{bD}$ & 11,8 & $\mathrm{bD}$ & 14,0 & $a c$ & 11,8 & $\mathrm{D}$ & 0,17 \\
\hline Outono & 15,5 & $\mathrm{c} \mathrm{C}$ & 23,3 & $\mathrm{~b} C$ & 24,9 & $\mathrm{~b} \mathrm{C}$ & 35,5 & a B & 24,8 & $\mathrm{C}$ & 1,07 \\
\hline Inverno & 22,3 & $\mathrm{c} \mathrm{B}$ & 28,9 & b B & 30,2 & b B & 39,6 & a B & 30,3 & B & 1,04 \\
\hline Ini. Prim. & 39,4 & $\mathrm{~b} \mathrm{~A}$ & 65,8 & a A & 63,3 & $\mathrm{a} A$ & 60,0 & a A & 57,1 & A & 1,98 \\
\hline Fin. Prim. & 10,0 & $\mathrm{bD}$ & 12,0 & a D & 12,4 & a D & 12,4 & a D & 11,7 & D & 0,24 \\
\hline Média $^{\dagger}$ & 16,6 & $\mathrm{c}$ & 23,4 & $\mathrm{~b}$ & 23,9 & $\mathrm{~b}$ & 28,1 & a & & & \\
\hline $\mathrm{EPM}^{*}$ & 0,792 & & 0,768 & & 0,768 & & 0,768 & & & & \\
\hline
\end{tabular}

Erro padrão da média

Erro padrão da média da interação: Verão= 0,34; Outono= 2,14; Inverno= 2,08; Ini. Prim.= 3,96; Fin. Prim. $=0,48$.

Médias seguidas da mesma letra minúscula na linha e maiúscula na coluna não diferem entre si $(\mathrm{P}>0,10)$

${ }^{\dagger}$ As médias das alturas correspondem à mé dia de todos os meses do experimento

Para o filocrono expresso em graus-dia, houve efeito de altura do dossel $(\mathrm{P}=0,0002)$, época do ano $(\mathrm{P}<0,0001)$ e interação altura do dossel $\mathrm{x}$ época do ano $(\mathrm{P}<0,0001)$. Os resultados indicam um padrão de resposta semelhante àquele observado para o filocrono expresso em dias (Tabela 10), com os valores mais altos sendo registrados nos dosséis mantidos mais altos (Tabela 11). Foi detectado um efeito sazonal bastante acentuado, com valores de 545 graus-dia.folha $^{-1}$ no início da primavera e de 114 graus-dia.folha ${ }^{-1}$ no verão. 
Tabela 11. Filocrono (graus-dia.folha ${ }^{-1}$ ) em perfilhos de capim-Marandu mantidos em quatro alturas de dossel forrageiro por meio de lotação contínua em diferentes épocas do ano

\begin{tabular}{|c|c|c|c|c|c|c|c|c|c|c|c|}
\hline \multirow{2}{*}{$\begin{array}{c}\text { Epoca do } \\
\text { ano }\end{array}$} & \multicolumn{8}{|c|}{ Altura $(\mathrm{cm})$} & \multirow{2}{*}{\multicolumn{2}{|c|}{ Média }} & \multirow{2}{*}{$\mathrm{EPM}^{*}$} \\
\hline & 10 & & 20 & & 30 & & 40 & & & & \\
\hline Verão & 98,4 & $b$ & 108,5 & $\mathrm{aD}$ & 114,7 & $\mathrm{aD}$ & 133,4 & $a c$ & 113,7 & D & 6,21 \\
\hline Outono & 98,6 & c C & 148,1 & b BC & 154,8 & b B & 231,5 & a B & 158,2 & B & 5,25 \\
\hline Inverno & 122,7 & c B & 158,7 & b B & 166,2 & b B & 217,9 & a B & 166,4 & B & 18,89 \\
\hline Ini. Prim. & 365,9 & b A & 637,7 & a A & 614,0 & a A & 582,3 & a A & 545,0 & A & 1,98 \\
\hline Fin. Prim. & 105,2 & b BC & 125,8 & a C & 130,6 & a C & 129,4 & a C & 122,7 & C & 2,55 \\
\hline Média $^{\dagger}$ & 167,6 & $\mathrm{c}$ & 240,6 & $\mathrm{~b}$ & 245,9 & $\mathrm{~b}$ & 287,0 & $\mathrm{a}$ & & & \\
\hline EPM $^{*}$ & 8,09 & & 8,09 & & 8,09 & & 8,24 & & & & \\
\hline
\end{tabular}

Erro padrão da média

Erro padrão da média da interação: Verão=12,42, Outono=10,50, Inverno=37,8, hi. Prim.=4,0 e Fin. Prim. $=5,10$.

Médias seguidas da mesma letra minúscula na linha e maiúscula na coluna não diferem entre si $(\mathrm{P}>0,10)$

${ }^{\dagger}$ As médias das alturas correspondem à média de todos os meses do experimento

Para os valores de filocrono calculados com base no conceito de unidades fototérmicas (UF), houve efeito de altura do dossel $(\mathrm{P}=0,0033)$, época do ano $(\mathrm{P}<0,0001)$ e interação altura do dossel $\mathrm{x}$ época do ano $(\mathrm{P}=0,0002)$. De maneira semelhante ao relatado para o filocrono em graus-dia, os menores valores foram registrados para dosséis mantidos a $10 \mathrm{~cm}$ de altura (6145 UF.folha ${ }^{-1}$ ). Já para as alturas de 20, 30 e $40 \mathrm{~cm}$ os valores não diferiram, oscilando em torno de 9211 UF.folha $^{-1}$ (Tabela 12). Em relação às épocas do ano, o maior valor foi registrado no início da primavera (37394 UF.folha ${ }^{-1}$ ) e o menor durante o período de verão (2712 UF.folha ${ }^{-1}$ ). 
Tabela 12. Filocrono (unidades fototérmicas.folha ${ }^{-1}$ ) em perfilhos de capim-Marandu mantidos em quatro alturas de dossel forrageiro por meio de lotação contínua em diferentes épocas do ano

\begin{tabular}{|c|c|c|c|c|c|c|c|c|c|c|c|}
\hline \multirow{2}{*}{$\begin{array}{c}\text { Epoca do } \\
\text { ano }\end{array}$} & \multicolumn{8}{|c|}{ Altura $(\mathrm{cm})$} & \multirow{2}{*}{ Média } & \multirow{2}{*}{\multicolumn{2}{|c|}{$\mathrm{EPM}^{*}$}} \\
\hline & 10 & & 20 & & 30 & & 40 & & & & \\
\hline Verão & 2326 & $a c$ & 2559 & $\mathrm{aD}$ & 2724 & $\mathrm{aD}$ & 3241 & $\mathrm{aE}$ & 2712 & $\mathrm{E}$ & 238,7 \\
\hline Outono & 2381 & c C & 3630 & bc C & 3794 & b C & 5734 & a D & 3885 & D & 281,1 \\
\hline Inverno & 5618 & c B & 7267 & b B & 7609 & b B & 9976 & a B & 7618 & B & 258,9 \\
\hline Ini. Prim. & 25901 & $\mathrm{~b} A$ & 43005 & $\mathrm{aA}$ & 41397 & a A & 39272 & a A & 37394 & A & 1250,9 \\
\hline Fin. Prim. & 5632 & b B & 6737 & a B & 6990 & a B & 6926 & a C & 6571 & C & 182,3 \\
\hline Média $^{\dagger}$ & 6145 & b & 8993 & a & 8969 & a & 9670 & a & & & \\
\hline $\mathrm{EPM}^{*}$ & 349 , & & 337,7 & & 337,7 & & 337, & & & & \\
\hline
\end{tabular}

Erro padrão da média

Erro padrão da média da interação: Verão=474,4, Outono=562,2, Inverno=517,8, Ini. Prim. $=2501,8$ e Fin. Prim.=364,6.

Médias seguidas da mesma letra minúscula na linha e maiúscula na coluna não diferem entre si $(\mathrm{P}>0,10)$

$\dagger$ As médias das alturas correspondem à média de todos os meses do experime nto

Para a longevidade de folhas expressa em dias (LF), foi detectado efeito de altura do dossel $(\mathrm{P}<0,0001)$, época do ano $(\mathrm{P}<0,0001)$ e interação altura do dossel x época do ano $(\mathrm{P}<0,0001)$. Dosséis mantidos a $40 \mathrm{~cm}$ apresentaram folhas mais longevas (124 dias) que os demais, sendo que aqueles mantidos a $10 \mathrm{~cm}$ apresentaram folhas com menor longevidade (66 dias). Ao longo do ano, a maior longevidade de folhas foi registrada no início da primavera (227 dias). Já durante a época de verão o período de vida das folhas foi por volta de 51 dias. Valores intermediários foram verificados para os períodos de outono e inverno (Tabela 13). 
Tabela 13. Longevidade de folhas (dias.folha ${ }^{-1}$ ) em perfilhos de capim-Marandu mantidos em quatro alturas de dossel forrageiro por meio de lotação contínua em diferentes épocas do ano

\begin{tabular}{|c|c|c|c|c|c|c|c|c|c|c|c|}
\hline \multirow{2}{*}{$\begin{array}{c}\text { Época do } \\
\text { ano }\end{array}$} & \multicolumn{8}{|c|}{ Altura $(\mathrm{cm})$} & \multirow{2}{*}{\multicolumn{2}{|c|}{ Média }} & \multirow{2}{*}{$\mathrm{EPM}^{*}$} \\
\hline & \multicolumn{2}{|c|}{10} & \multicolumn{2}{|l|}{20} & \multicolumn{2}{|l|}{30} & \multicolumn{2}{|c|}{40} & & & \\
\hline Verão & 37,1 & $d E$ & 48,7 & $\mathrm{CD}$ & 52,6 & $\mathrm{bD}$ & 63,9 & $a c$ & 50,6 & & 0,80 \\
\hline Outono & 68,2 & $\mathrm{~d} C$ & 96,1 & c C & 118,3 & b B & 157,7 & a B & 110,1 & $\mathrm{C}$ & 3,35 \\
\hline Inverno & 96,9 & c B & 120,5 & b B & 129,3 & b B & 157,2 & a B & 126,0 & B & 4,33 \\
\hline Ini. Prim. & 139,5 & b A & 247,8 & a A & 266,3 & a A & 255,6 & a A & 227,3 & A & 7,34 \\
\hline Fin. Prim. & 45,8 & b D & 54,0 & b D & 66,6 & a $C$ & 68,8 & a $C$ & 58,8 & D & 1,74 \\
\hline Média $^{\dagger}$ & 66,2 & d & 95,1 & $\mathrm{c}$ & 107,1 & $\mathrm{~b}$ & 124,2 & a & & & \\
\hline $\mathrm{EPM}^{*}$ & 2,8 & & 2,81 & & 2,81 & & 2,8 & & & & \\
\hline
\end{tabular}

Erro padrão da média

Erro padrão da nédia da interação: Verão=1,60, Outono=6,70 Inverno=8,66, Ini. Prim.=14,68 e Fin. Prim. $=3,48$.

Médias seguidas da mesma letra minúscula na linha e maiúscula na coluna não diferem entre si $(\mathrm{P}>0,10)$

$\dagger$ As médias das alturas correspondem à média de todos os meses do experimento

A longevidade de folhas calculada em graus-dia apresentou um padrão de resposta muito semelhante àquele observado para longevidade expressa em dias. Para essa variável foi detectado efeito de altura do dossel $(\mathrm{P}<0,0001)$, época do ano $(\mathrm{P}<0,0001)$ e interação altura do dossel $\mathrm{x}$ época do ano $(\mathrm{P}<0,0001)$. Os valores maiores foram registrados nos dosséis mantidos a $40 \mathrm{~cm}$, nos quais a duração de vida das folhas foi equivalente a 1269 graus-dia. No outro extremo, em dosséis mantidos a $10 \mathrm{~cm}$, a longevidade foi de 682 graus-dia (Tabela 14). Em relação às épocas do ano, a maior longevidade das folhas foi registrada no início da primavera (2341 graus-dia) e a menor no verão (516 graus-dia) 
Tabela 14. Longevidade de folhas (graus.dia.folha ${ }^{-1}$ ) em perfilhos de capim-Marandu mantidos em quatro alturas de dossel forrageiro através de lotação contínua em diferentes épocas do ano

\begin{tabular}{|c|c|c|c|c|c|c|c|c|c|c|c|}
\hline \multirow{2}{*}{$\begin{array}{c}\text { Época do } \\
\text { ano }\end{array}$} & \multicolumn{8}{|c|}{ Altura (cm) } & \multirow{2}{*}{\multicolumn{2}{|c|}{ Média }} & \multirow{2}{*}{ EPM* } \\
\hline & \multicolumn{2}{|c|}{10} & \multicolumn{2}{|c|}{20} & \multicolumn{2}{|c|}{30} & \multicolumn{2}{|c|}{40} & & & \\
\hline Verão & 383 & cE & 501 & $\mathrm{DD}$ & 542 & $\mathrm{DD}$ & 637 & $\mathrm{aD}$ & 516 & E & 15,4 \\
\hline Outono & 702 & $\mathrm{~d} \mathrm{C}$ & 990 & $\mathrm{cC}$ & 1219 & b B & 1624 & a B & 1134 & C & 33,1 \\
\hline Inverno & 998 & c B & 1241 & $\mathrm{~b} B$ & 1332 & b B & 1619 & a B & 1298 & B & 42,4 \\
\hline Ini. Prim. & 1437 & b A & 2552 & $\mathrm{aA}$ & 2743 & a A & 2632 & a A & 2341 & A & 74,6 \\
\hline Fin. Prim. & 472 & c D & 556 & $\mathrm{bD}$ & 686 & a C & 709 & a C & 606 & D & 13,1 \\
\hline Média $^{\dagger}$ & 682 & d & 979 & $\mathrm{c}$ & 1102 & $\mathrm{~b}$ & 1269 & a & & & \\
\hline $\mathrm{EPM}^{*}$ & 27,2 & & 27,2 & & 27,2 & & 27,2 & & & & \\
\hline
\end{tabular}

Erro padrão da média

Erro padrão da média da interação: Verão=30,8, Outono=66,2 Inverno=84,8, Ini. Prim.=149,2 e Fin. Prim. $=26,1$.

Médias seguidas da mesma letra minúscula na linha e maiúscula na coluna não diferem entre si $(\mathrm{P}>0,10)$

${ }^{\dagger}$ As médias das alturas correspondem à média de todos os meses do experimento

\subsubsection{Comprimento médio de folhas intactas e da haste}

O comprimento de folhas intactas (CFI) aumentou com o aumento da altura do dossel. A análise estatística indicou efeito de altura do dossel $(\mathrm{P}<0,0001)$, época do ano $(\mathrm{P}<0,0001)$ e interação altura do dossel x época do ano $(\mathrm{P}=0,0142)$. De uma forma geral, os valores não ultrapassaram $25 \mathrm{~cm}$, sendo que na média do ano os pastos de 30 e $40 \mathrm{~cm}$ apresentaram folhas com $21,2 \mathrm{~cm}$ (Tabela 15). No outro extremo, nos pastos mantidos a $10 \mathrm{~cm}$, o CFI foi de 11,4 cm. Em relação às épocas do ano, os valores foram relativamente constantes durante os períodos de outono, início e final da primavera (média de 17,5 cm por folha). Já durante o período de inverno as 6lhas foram, em média, 2,3 cm maiores, com 19,8 cm de comprimento. O menor valor foi registrado durante o período de verão $(16,2 \mathrm{~cm})$. 
Tabela 15. Comprimento médio de folha intacta $\left(\mathrm{cm} \cdot \mathrm{folha}^{-1}\right)$ em perfilhos de capimMarandu mantidos em quatro alturas de dossel forrageiro por meio de lotação contínua em diferentes épocas do ano

\begin{tabular}{|c|c|c|c|c|c|c|c|c|c|c|c|}
\hline \multirow{2}{*}{$\begin{array}{c}\text { Época do } \\
\text { ano }\end{array}$} & \multicolumn{8}{|c|}{ Altura $(\mathrm{cm})$} & \multirow{2}{*}{\multicolumn{2}{|c|}{ Média }} & \multirow{2}{*}{$\mathrm{EPM}^{*}$} \\
\hline & \multicolumn{2}{|c|}{10} & \multicolumn{2}{|c|}{20} & \multicolumn{2}{|c|}{30} & \multicolumn{2}{|c|}{40} & & & \\
\hline Verão & 10,3 & $\mathrm{~dB}$ & 14,9 & $\mathrm{CA}$ & 19,1 & be & 20,6 & $\mathrm{aB}$ & 16,2 & e & 0,29 \\
\hline Outono & 11,1 & $\mathrm{c} A B$ & 15,2 & $\mathrm{~b} A$ & 21,9 & a $\mathrm{AB}$ & 21,8 & a B & 17,5 & B & 0,35 \\
\hline Inverno & 13,3 & b A & 16,5 & $\mathrm{~b} A$ & 24,6 & a A & 24,9 & a A & 19,8 & A & 0,66 \\
\hline Ini. Prim. & 12,5 & $\mathrm{c} \mathrm{A}$ & 16,0 & $\mathrm{~b} \mathrm{~A}$ & 20,8 & a BC & 22,3 & a B & 17,9 & B & 0,53 \\
\hline Fin. Prim. & 12,7 & $\mathrm{c} \mathrm{A}$ & 15,1 & b A & 20,1 & a BC & 20,7 & a B & 17,1 & $\mathrm{BC}$ & 0,43 \\
\hline Média $^{\dagger}$ & 11,4 & c & 15,3 & $\mathrm{~b}$ & 20,8 & $\mathrm{a}$ & 21,6 & $\mathrm{a}$ & & & \\
\hline $\mathrm{EPM}^{*}$ & 0,40 & & 0,40 & & 0,40 & & 0,40 & & & & \\
\hline
\end{tabular}

Erro padrão da média

Erro padrão da média da interação: Verão=0,58, Outono=0,70, Inverno=1,32, Ini. Prim.=1,06, Fin. Prim. $=0,86$

Médias seguidas da mesma letra minúscula na linha e maiúscula na coluna não diferem entre si $(\mathrm{P}>0,10)$

${ }^{\dagger}$ As médias das alturas correspondem à média de todos os meses do experimento

O comprimento da haste $(\mathrm{CPH})$ dos perfilhos apresentou padrão de resposta similar ao CFI. Foi detectado efeito de altura do dossel $(\mathrm{P}<0,0001)$, época do ano $(\mathrm{P}=0,0399)$ e interação altura do dossel $\mathrm{x}$ época do ano $(\mathrm{P}=0,0606)$. Pastos mantidos mais altos tiveram perfilhos maiores e com maior comprimento de haste (Tabela 16). Os valores de $\mathrm{CPH}$ representaram uma proporção relativamente constante da altura em que os dosséis foram mantidos. De forma geral, os valores de CPH variaram de 76 a $83 \%$ da altura do dossel. Em relação ás épocas do ano, os dosséis apresentaram os menores valores no $\mathrm{CPH}$ (cerca de $19 \mathrm{~cm}$ ) durante o período de início de primavera, contrastando com os períodos de verão, outono e inverno, quando as hastes atingiram cerca de 20,8 $\mathrm{cm}$. 
Tabela 16. Comprimento médio da haste $(\mathrm{cm})$ em perfilhos de capim-Marandu mantidos em quatro alturas de dossel forrageiro por meio de lotação contínua em diferentes épocas do ano

\begin{tabular}{|c|c|c|c|c|c|c|c|c|c|c|c|}
\hline \multirow{2}{*}{$\begin{array}{c}\text { Epoca do } \\
\text { ano }\end{array}$} & \multicolumn{8}{|c|}{ Altura $(\mathrm{cm})$} & \multirow{2}{*}{\multicolumn{2}{|c|}{ Média }} & \multirow{2}{*}{ EPM" } \\
\hline & 1 & & 2 & & 30 & & 40 & & & & \\
\hline Verão & 8,2 & $\mathrm{~d} A \mathrm{~B}$ & 18,0 & $\mathrm{cA}$ & 24,3 & $\mathrm{DBC}$ & 32,4 & $\mathrm{a} A \mathrm{~B}$ & 20,7 & A & 0,53 \\
\hline Outono & 7,6 & $\mathrm{~d} A \mathrm{AB}$ & 14,5 & c B & 26,5 & $\mathrm{~b}$ AB & 34,4 & $\mathrm{a} A \mathrm{~B}$ & 20,7 & A & 0,53 \\
\hline Inverno & 8,6 & c A & 13,9 & b AB & 28,9 & a A & 32,2 & $\mathrm{a} A \mathrm{~B}$ & 20,9 & A & 0,97 \\
\hline Ini. Prim. & 5,5 & d B & 14,5 & c B & 23,5 & $\mathrm{~b} C$ & 33,0 & a B & 19,1 & B & 0,46 \\
\hline Fin. Prim. & 8,3 & d A & 13,4 & c B & 22,3 & b C & 35,5 & a A & 19,9 & $\mathrm{AB}$ & 0,55 \\
\hline Média $^{\dagger}$ & 7,8 & d & 15,6 & $\mathrm{c}$ & 25,1 & b & 33,3 & a & & & \\
\hline $\mathrm{EPM}^{*}$ & 0,36 & & 0,34 & & 0,34 & & 0,34 & & & & \\
\hline
\end{tabular}

Erro padrão da média

Erro padrão da média da interação: Verão=1,06, Outono=1,06, Inverno=1,94, Ini. Prim.=0,92, Fin. Prim.=1,10

Médias seguidas da mesma letra minúscula na linha e maiúscula na coluna não diferem entre si $(\mathrm{P}>0,10)$

${ }^{\dagger}$ As médias das alturas correspondem à média de todos os meses do experimento

\subsection{Perfilhamento}

\subsubsection{Densidade populacional de perfilhos}

Houve efeito de altura do dossel $(\mathrm{P}<0,0001)$ e época do ano $(\mathrm{P}<0,0001)$ para essa variável. O maior valor de densidade populacional de perfilhos (DPP) foi verificado em pastos mantidos a $10 \mathrm{~cm}\left(1069\right.$ perfilhos. $\left.\mathrm{m}^{-2}\right)$. Os valores de DPP foram decrescentes com o aumento em altura do dossel, sendo que pastos mantidos a $40 \mathrm{~cm}$ apresentaram os menores valores (Tabela 17 e Figura 13). 
Tabela 17. Densidade populacional de perfilhos (perfilhos. $\mathrm{m}^{-2}$ ) em pastos de capimMarandu mantidos em quatro alturas de dossel forrageiro por meio de lotação contínua em diferentes épocas do ano

\begin{tabular}{|c|c|c|c|c|c|c|c|c|c|}
\hline \multirow{2}{*}{$\begin{array}{c}\text { Época do } \\
\text { ano }\end{array}$} & \multicolumn{5}{|c|}{ Altura $(\mathrm{cm})$} & & \multirow{2}{*}{\multicolumn{2}{|c|}{ Média }} & \multirow{2}{*}{ EPM $^{*}$} \\
\hline & 10 & & 20 & 30 & 40 & & & & \\
\hline Verão & 1301 & & 1178 & 1059 & $\overline{914}$ & & 1113 & . & 22 \\
\hline Outono & 1081 & & 1009 & 969 & 746 & & 951 & B & 22 \\
\hline Inverno & 958 & & 877 & 656 & 523 & & 753 & $\mathrm{D}$ & 22 \\
\hline Ini. Prim. & 949 & & 831 & 665 & 486 & & 732 & D & 22 \\
\hline Fin. Prim. & 934 & & 881 & 830 & 658 & & 826 & C & 22 \\
\hline Média $^{\dagger}$ & 1069 & $\mathrm{a}$ & 978 & 865 & 692 & d & & & \\
\hline EPM $^{*}$ & 18 & & 18 & 18 & 18 & & & & \\
\hline
\end{tabular}

Erro padrão da média

Médias seguidas da mesma letra minúscula na linha e maiúscula na coluna não diferem entre si $(\mathrm{P}>0,10)$

${ }^{\dagger}$ As médias das alturas correspondem à média de todos os meses do exp erimento

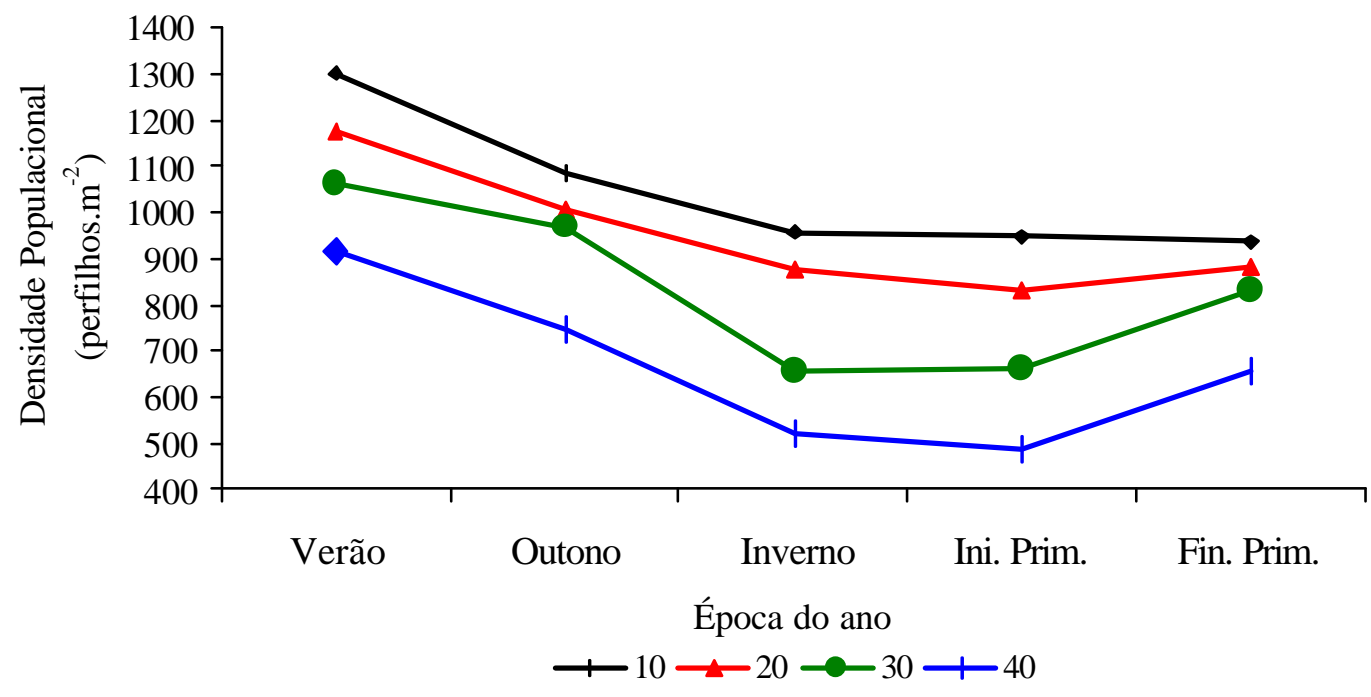

Figura 13 - Densidade populacional de perfilhos em pastos de capim-Marandu mantidos a 10, 20, 30 e $40 \mathrm{~cm}$ de altura por bovinos de corte em lotação contínua em diferentes épocas do ano 
Em relação às épocas do ano, os naiores valores foram registrados durante o período de verão (1113 perfilhos. $\mathrm{m}^{-2}$ ). No restante do ano, conforme as estações foram avançando, houve um decréscimo em DPP, com os valores mais baixos sendo registrados durante o período de inverno e início de primavera (Tabela 17 e Figura 13). Durante o final de primavera os pastos apresentaram uma elevação na DPP.

\subsubsection{Proporção de perfilhos com inflorescência visível}

Houve efeito de altura do dossel $(\mathrm{P}<0,0001)$, época do ano $(\mathrm{P}<0,0001)$ e interação altura do dossel x época do ano $(\mathrm{P}<0,0001)$. Pastos mantidos a $40 \mathrm{~cm}$ apresentaram uma maior proporção de perfilhos florescidos $(4,65 \%)$ que pastos mantidos a $10 \mathrm{~cm}(0,43 \%)$.

Tabela 18. Percentual de perfilhos com inflorescência visível em pastos de capimMarandu mantidos em quatro alturas de dossel forrageiro através de lotação contínua em diferentes épocas do ano

\begin{tabular}{cccccccccccc}
\hline $\begin{array}{c}\text { Época do } \\
\text { ano }\end{array}$ & \multicolumn{9}{c}{10} & \multicolumn{9}{c}{20} & \multicolumn{2}{c}{30} & & \multicolumn{2}{c}{40} & & Média & \multirow{2}{*}{ EPM $^{*}$} \\
\hline Verão & 0,43 & c A & 1,88 & c AB & 4,07 & b A & 6,16 & a B & 3,14 & B & 0,291 \\
Outono & 0,57 & d A & 2,86 & c A & 4,73 & b A & 9,70 & a A & 4,47 & A & 0,244 \\
Inverno & 0,80 & c A & 2,27 & bc A & 4,28 & a A & 3,42 & ab C & 2,69 & B & 0,342 \\
Ini. Prim. & 0,34 & c A & 0,51 & c BC & 2,07 & b B & 3,42 & a C & 1,59 & C & 0,256 \\
Fin. Prim. & 0,00 & b A & 0,05 & b C & 0,13 & b C & 0,55 & a D & 0,18 & D & 0,025 \\
Média $^{\dagger}$ & 0,43 & d & 1,51 & c & 3,06 & b & 4,65 & a & & & \\
EPM $^{*}$ & 0,21 & & 0,21 & & 0,21 & & 0,21 & & & & \\
\hline
\end{tabular}

"Erro padrão da média

Erro padrão da média da interação: Verão=0,59, Outono=0,49, Inverno=0,80, Ini. Prim.=0,34, Fin. Prim. $<0,0001$

Médias seguidas da mesma letra minúscula na linha e maiúscula na coluna não diferem entre si $(\mathrm{P}>0,10)$

${ }^{\dagger}$ As médias das alturas correspondem à média de todos os meses do experimento 
Durante o inverno, os pastos mantidos a $30 \mathrm{~cm}$ apresentaram maior proporção de perfilhos florescidos que pastos mantidos a $40 \mathrm{~cm}$. Em relação às épocas do ano, as maiores proporções foram registradas no período de outono, época em que 4,47\% dos perfilhos estavam com inflorescência visível. Já durante o final da primavera essa proporção foi de $0,18 \%$. De maneira geral, apesar das proporções variáveis, pastos de capim-Marandu apresentaram perfilhos florescidos durante a maior parte do ano (Tabela 18).

\subsubsection{Taxas de aparecimento, sobrevivência e mortalidade de perfilhos}

Para a taxa de aparecimento de perfilhos (TAP), houve efeito de altura do dossel $(\mathrm{P}=0,0046)$, época do ano $(\mathrm{P}<0,0001)$ e interação altura do dossel $\mathrm{x}$ época do ano $(\mathrm{P}=0,0195)$. Os maiores valores de TAP foram verificados em pastos mantidos a $10 \mathrm{~cm}$ $(32,2 \%)$ Já os pastos mantidos a 30 e $40 \mathrm{~cm}$ apresentaram os menores valores, cerca de 26,5\% (Tabela 19 e Figuras 14 a 17). Em relação às épocas do ano, os maiores valores de TAP foram verificados nos períodos de verão e final de primavera (cerca de 40\%) e os menores durante o início da primavera (12\%) (Tabela 19).

Para as taxas de sobrevivência de perfilhos (TSP), houve efeito de altura do dossel $(\mathrm{P}<0,0001)$, época do ano $(\mathrm{P}<0,0001)$ e interação altura do dossel $\mathrm{x}$ época do ano $(\mathrm{P}=0,072)$. Pastos mantidos a 30 e $40 \mathrm{~cm}$ apresentaram as maiores TSP $(76,5 \%$, em média). O menor valor foi registrado para pastos mantidos a $10 \mathrm{~cm}(68,6 \%)$ (Tabela 20). Em relação às épocas do ano, as maiores TSP ocorreram durante os períodos mais frios e secos do ano, inverno e início de primavera, onde, em média, os dosséis apresentaram uma sobrevivência de perfilhos de $81,7 \%$, contrastando com os períodos de verão e outono, onde foram registradas TSP de 66,6 \%, em média. 
Tabela 19. Taxa de aparecimento de perfilhos (\%) em pastos de capim-Marandu mantidos em quatro alturas de dossel forrageiro por meio de lotação contínua em diferentes épocas do ano

\begin{tabular}{|c|c|c|c|c|c|c|c|c|c|c|c|}
\hline \multirow{2}{*}{$\begin{array}{c}\text { Epoca do } \\
\text { ano }\end{array}$} & \multicolumn{8}{|c|}{ Altura $(\mathrm{cm})$} & \multirow{2}{*}{\multicolumn{2}{|c|}{ Média }} & \multirow{2}{*}{ EPM" } \\
\hline & 10 & & 20 & & 30 & & 40 & & & & \\
\hline Verão & 47,9 & $\mathrm{aA}$ & 39,9 & $\mathrm{bA}$ & 31,4 & $\mathrm{CB}$ & 41,4 & $\mathrm{ab} \mathrm{A}$ & 40,2 & A & 1,48 \\
\hline Outono & 28,3 & ab B & 27,7 & $a b$ B & 23,6 & b C & 32,9 & a B & 28,1 & B & 1,14 \\
\hline Inverno & 20,1 & $\mathrm{aC}$ & 18,7 & a C & 14,7 & ab D & 10,5 & $\mathrm{~b} C$ & 16,0 & $\mathrm{C}$ & 1,55 \\
\hline Ini. Prim. & 13,1 & ab D & 9,2 & b D & 11,0 & ab D & 14,3 & a C & 11,9 & $\mathrm{D}$ & 0,94 \\
\hline Fin. Prim. & 45,7 & $\mathrm{a} A$ & 41,4 & a A & 39,8 & $\mathrm{ab} A$ & 32,7 & b B & 39,9 & A & 1,53 \\
\hline Média $^{\dagger}$ & 32,2 & $\mathrm{a}$ & 28,5 & $\mathrm{~b}$ & 24,7 & $\mathrm{c}$ & 28,2 & $\mathrm{bc}$ & & & \\
\hline EPM $^{*}$ & 1,35 & & 1,35 & & 1,35 & & 1,35 & & & & \\
\hline
\end{tabular}

*Erro padrão da média

Erro padrão da média da interação: Verão=2,96, Outono=2,28, Inverno=3,10, Ini. Prim.=1,88, Fin. Prim=3,06

Médias seguidas da mesma letra minúscula na linha e maiúscula na coluna não diferem entre si $(\mathrm{P}>0,10)$

$\dagger$ As médias das alturas correspondem à média de todos os meses do experimento

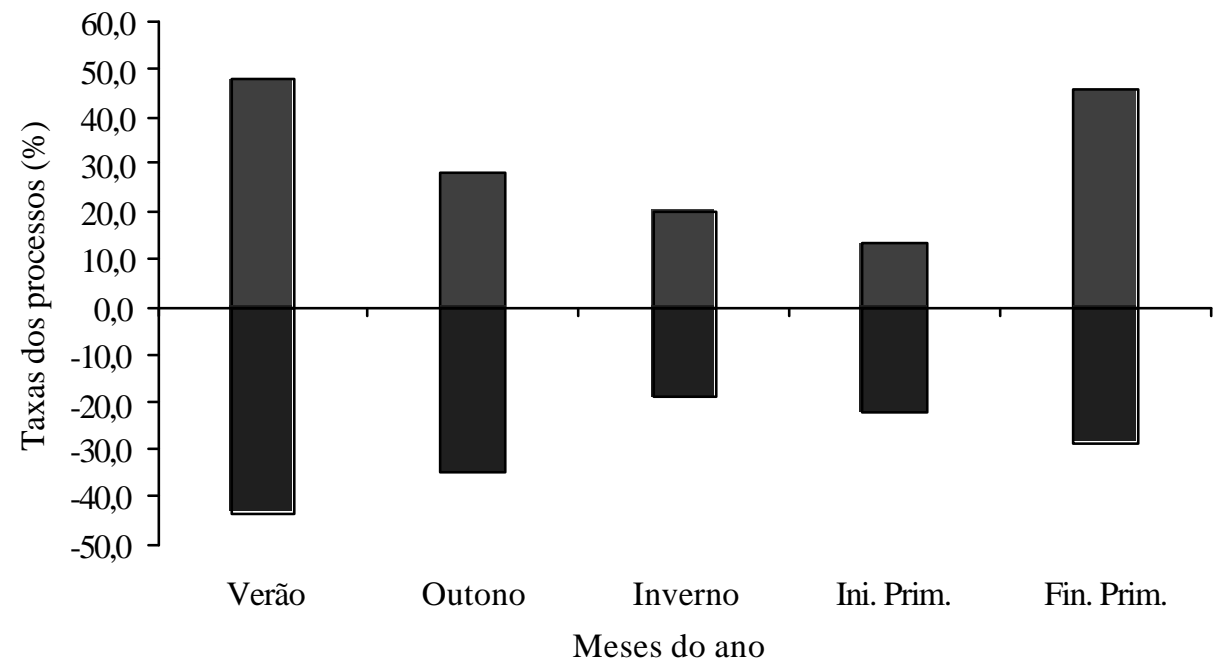

$\square$ Aparecimento $\square$ Mortalidade

Figura 14 - Taxas de aparecimento e mortalidade de perfilhos em pastos de capimMarandu mantidos a $10 \mathrm{~cm}$ de altura por bovinos em lotação contínua 


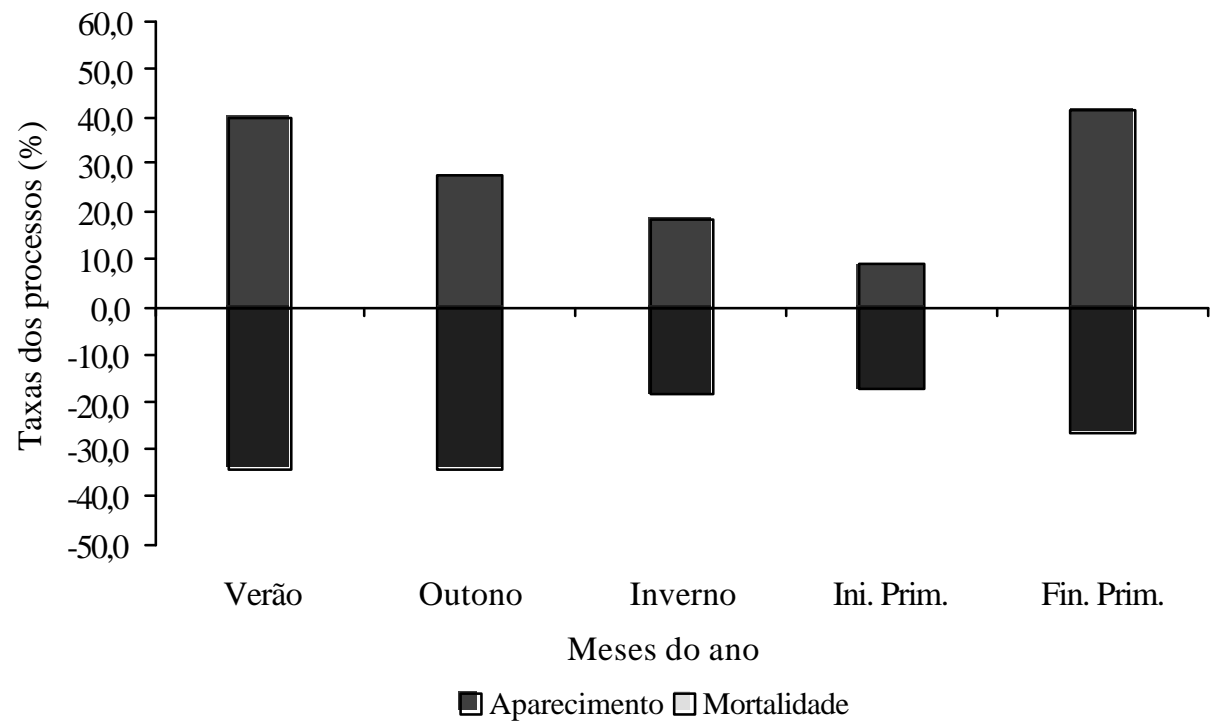

Figura 15 - Taxas de aparecimento e mortalidade de perfilhos em pastos de capimMarandu mantidos a $20 \mathrm{~cm}$ de altura por bovinos em lotação contínua

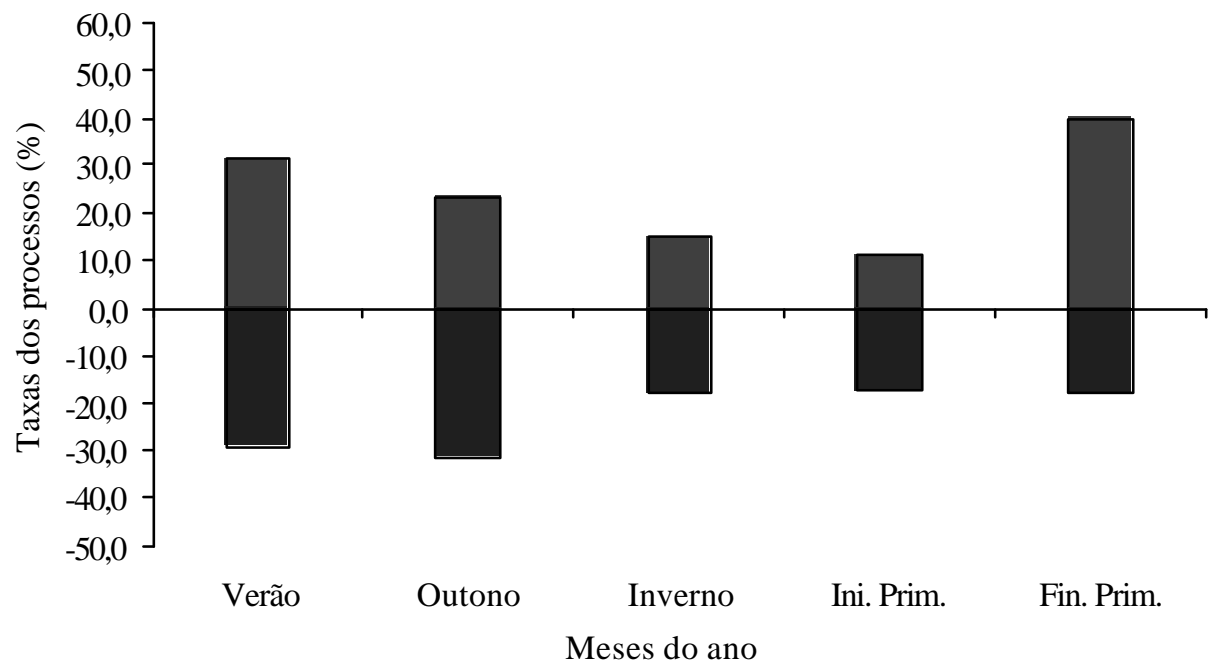

$\square$ Aparecimento $\square$ Mortalidade

Figura 16 - Taxas de aparecimento e mortalidade de perfilhos em pastos de capimMarandu mantidos a $30 \mathrm{~cm}$ de altura por bovinos em lotação contínua 


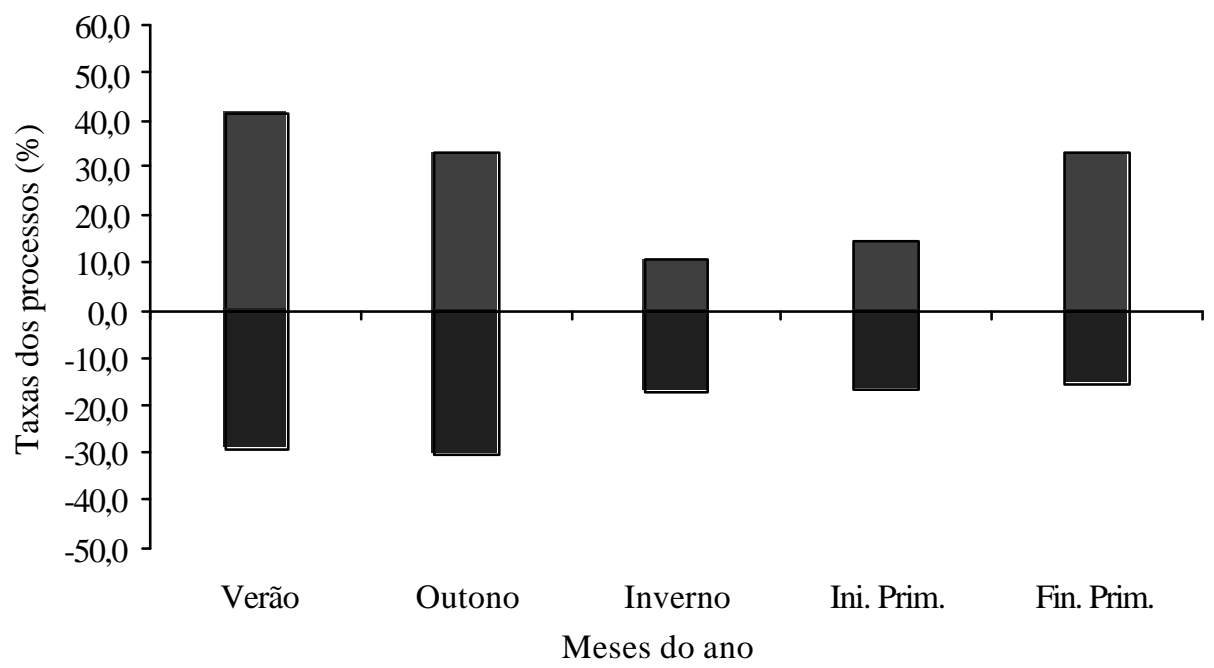

Aparecimento $\square$ Mortalidade

Figura 17 - Taxas de aparecimento e mortalidade de perfilhos em pastos de capimMarandu mantidos a $40 \mathrm{~cm}$ de altura por bovinos em lotação contínua

Tabela 20. Taxa de sobrevivência de perfilhos (\%) em pastos de capim-Marandu mantidos em quatro alturas de dossel forrageiro por meio de lotação contínua em diferentes épocas do ano

\begin{tabular}{|c|c|c|c|c|c|c|c|c|c|c|c|}
\hline \multirow{2}{*}{$\begin{array}{c}\text { Epoca do } \\
\text { ano }\end{array}$} & \multicolumn{8}{|c|}{ Altura $(\mathrm{cm})$} & \multirow{2}{*}{\multicolumn{2}{|c|}{ Média }} & \multirow{2}{*}{$\mathrm{EPM}^{*}$} \\
\hline & \multicolumn{2}{|c|}{10} & \multicolumn{2}{|c|}{20} & \multicolumn{2}{|c|}{30} & \multicolumn{2}{|c|}{40} & & & \\
\hline Verão & 56,4 & DE & 65,7 & $\mathrm{ac}$ & 70,6 & $\mathrm{ab}$ & 70,7 & $\mathrm{ab}$ & 65,8 & $c$ & 1,60 \\
\hline Outono & 64,7 & b D & 65,8 & ab C & 68,8 & a B & 69,6 & a B & 67,3 & $\mathrm{C}$ & 0,83 \\
\hline Inverno & 80,9 & a A & 81,5 & a A & 82,1 & a A & 83,1 & a A & 81,9 & A & 0,81 \\
\hline Ini. Prim. & 77,6 & b B & 82,6 & a A & 82,2 & a A & 83,6 & a A & 81,5 & A & 0,62 \\
\hline Fin. Prim. & 71,3 & $\mathrm{bC}$ & 73,5 & $\mathrm{~b} B$ & 82,1 & $\mathrm{a} A$ & 84,4 & a A & 77,8 & B & 1,10 \\
\hline Média $^{\dagger}$ & 68,6 & $\mathrm{c}$ & 72,5 & $\mathrm{~b}$ & 75,9 & $\mathrm{a}$ & 77,0 & $\mathrm{a}$ & & & \\
\hline $\mathrm{EPM}^{*}$ & 0,99 & & 0,99 & & 0,99 & & 0,99 & & & & \\
\hline
\end{tabular}

*Erro padrão da média

Erro padrão da média da interação: Verão=3,20, Outono=1,66, Inverno=1,62, Ini. Prim.=1,34, Fin. Prim. $=2,20$

Médias seguidas da mesma letra minúscula na linha e maiúscula na coluna não diferem entre si $(\mathrm{P}>0,10)$

${ }^{\dagger}$ As médias das alturas correspondem à média de todos os meses do experimento 
Com relação à taxa de mortalidade de perfilhos (TMP), houve efeito de altura do dossel $(\mathrm{P}<0,0001)$, época do ano $(\mathrm{P}<0,0001)$ e interação altura do dossel $\mathrm{x}$ época do ano $(\mathrm{P}=0,0792)$. Os maiores valores de TMP foram encontrados para pastos mantidos a 10 $\mathrm{cm}(31,4 \%)$ e os menores em pastos mantidos a 30 e $40 \mathrm{~cm}(23,6 \%)$. Em relação às épocas do ano, as maiores taxas de mortalidade (33,5\%, em média) foram registradas durante os períodos de verão e outono e as menores $(18,3 \%)$ durante o inverno e início de primavera (Tabela 21 e Figuras 14 a 17).

Tabela 21. Taxa de mortalidade de perfilhos (\%) em pastos de capim-Marandu mantidos em quatro alturas de dossel forrageiro por meio de lotação contínua em diferentes épocas do ano

\begin{tabular}{|c|c|c|c|c|c|c|c|c|c|c|c|}
\hline \multirow{2}{*}{$\begin{array}{c}\text { Epoca do } \\
\text { ano }\end{array}$} & \multicolumn{8}{|c|}{ Altura $(\mathrm{cm})$} & \multirow{2}{*}{\multicolumn{2}{|c|}{ Média }} & \multirow{2}{*}{$\mathrm{EPM}^{*}$} \\
\hline & \multicolumn{2}{|c|}{10} & \multicolumn{2}{|c|}{20} & \multicolumn{2}{|c|}{30} & \multicolumn{2}{|c|}{40} & & & \\
\hline Verão & 43,6 & $\mathrm{a} A$ & 34,3 & $\mathrm{bA}$ & 29,4 & $\mathrm{bA}$ & 29,3 & $\mathrm{bA}$ & 34,2 & A & 1,60 \\
\hline Outono & 35,3 & a B & 34,2 & ab A & 31,2 & $\mathrm{~b} A$ & 30,3 & b A & 32,8 & A & 0,83 \\
\hline Inverno & 19,0 & a E & 18,5 & $\mathrm{aC}$ & 17,9 & a B & 16,9 & a B & 18,1 & $\mathrm{C}$ & 0,81 \\
\hline Ini. Prim. & 22,3 & $\mathrm{a} D$ & 17,4 & $\mathrm{~b} C$ & 17,8 & b B & 16,3 & b B & 18,5 & C & 0,62 \\
\hline Fin. Prim. & 28,7 & a C & 26,6 & a B & 17,9 & b B & 15,6 & b B & 22,2 & B & 1,10 \\
\hline Média $^{\dagger}$ & 31,4 & $\mathrm{a}$ & 27,5 & $\mathrm{~b}$ & 24,1 & c & 23,1 & c & & & \\
\hline $\mathrm{EPM}^{*}$ & 0,99 & & 0,99 & & 0,99 & & 0,99 & & & & \\
\hline
\end{tabular}

*Erro padrão da média

Erro padrão da média da interação: Verão=3,20, Outono=1,66, Inverno=1,62, Ini. Prim.=1,34, Fin. Prim.=2,20

Médias seguidas da mesma letra minúscula na linha e maiúscula na coluna não diferem entre si $(\mathrm{P}>0,10)$

${ }^{\dagger}$ As médias das alturas correspondem à média de todos os meses do experimento

\subsubsection{Padrões demográficos do perfilhamento e diagramas de estabilidade}

A partir dos dados originais de contagem de perfilhos foram geradas, mensalmente, curvas mostrando o decréscimo no número de perfilhos por geração, bem 
como a oscilação mensal na população de perfilhos nos pastos. Como as avaliações não foram realizadas em intervalos de empo rigorosamente iguais (Tabela 4), todos os valores foram corrigidos para um período comum de 30 dias utilizando-se interpolação linear simples. Os dados dos padrões demográficos encontramse nas Figuras 18 a 21. Como característica comum a todas as alturas de dossel avaliadas, houve uma redução na população de perfilhos a partir de abril/maio. Os valores de densidade populacional permaneceram baixos durante todo o inverno e início da primavera, sendo que um aumento na população só ocorreu a partir do mês de novembro. Observa -se também que, apesar do reduzido aparecimento, as gerações dos meses de outono/inverno apresentaram uma sobrevivência maior que aquelas dos meses de verão. Essa constatação pode ser também visualizada nas Tabelas 19 e 21.

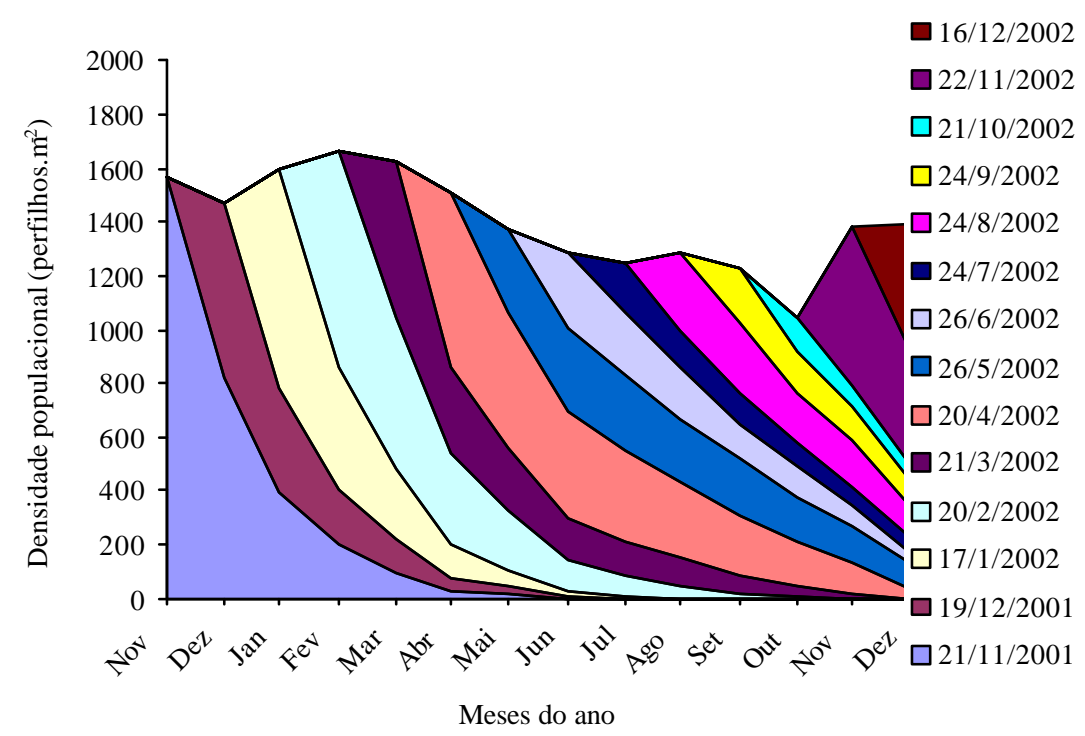

Figura 18 - Padrão demográfico do perfilhamento em pastos de capim-Marandu mantidos a $10 \mathrm{~cm}$ de altura do dossel forrageiro por bovinos em lotação contínua 


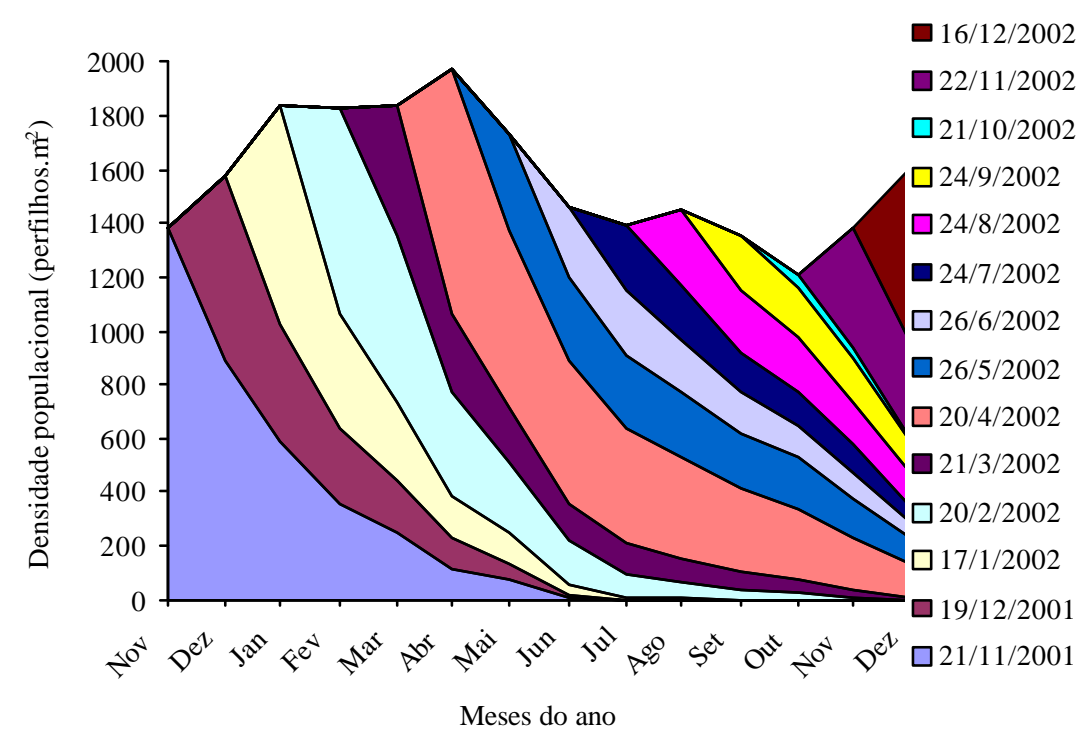

Figura 19 - Padrão demográfico do perfilhamento em pastos de capim-Marandu mantidos a $20 \mathrm{~cm}$ de altura do dossel forrageiro por bovinos em lotação contínua

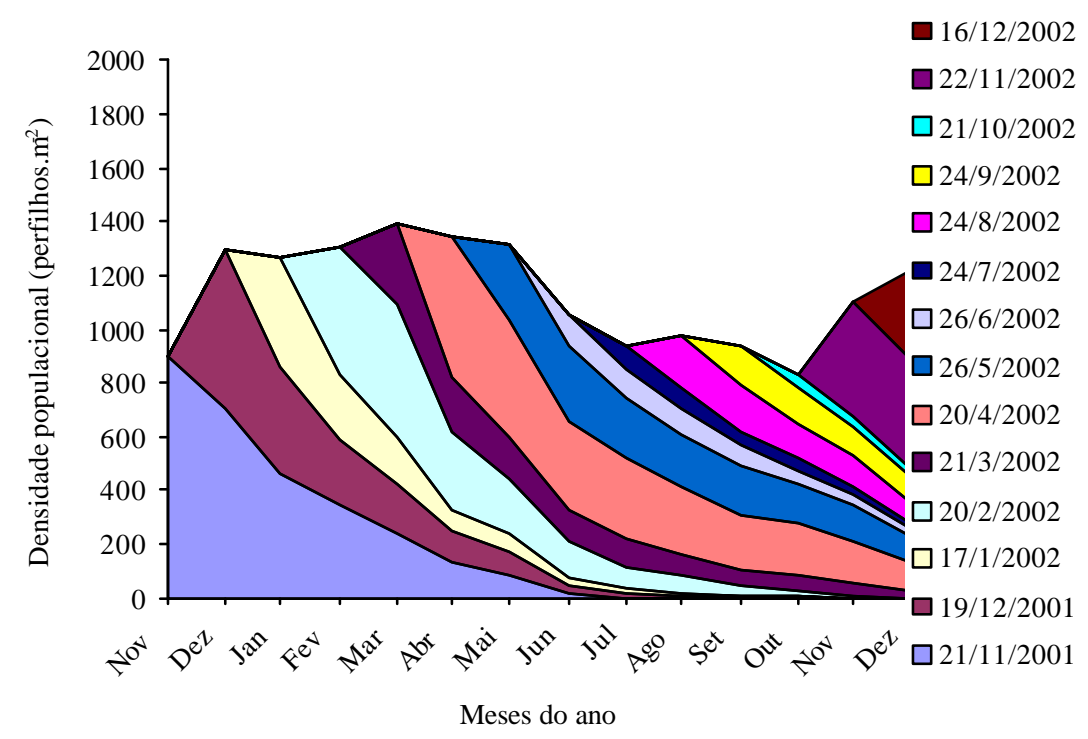

Figura 20 - Padrão demográfico do perfilhamento em pastos de capim-Marandu mantidos a $30 \mathrm{~cm}$ de altura do dossel forrageiro por bovinos em lotação contínua 


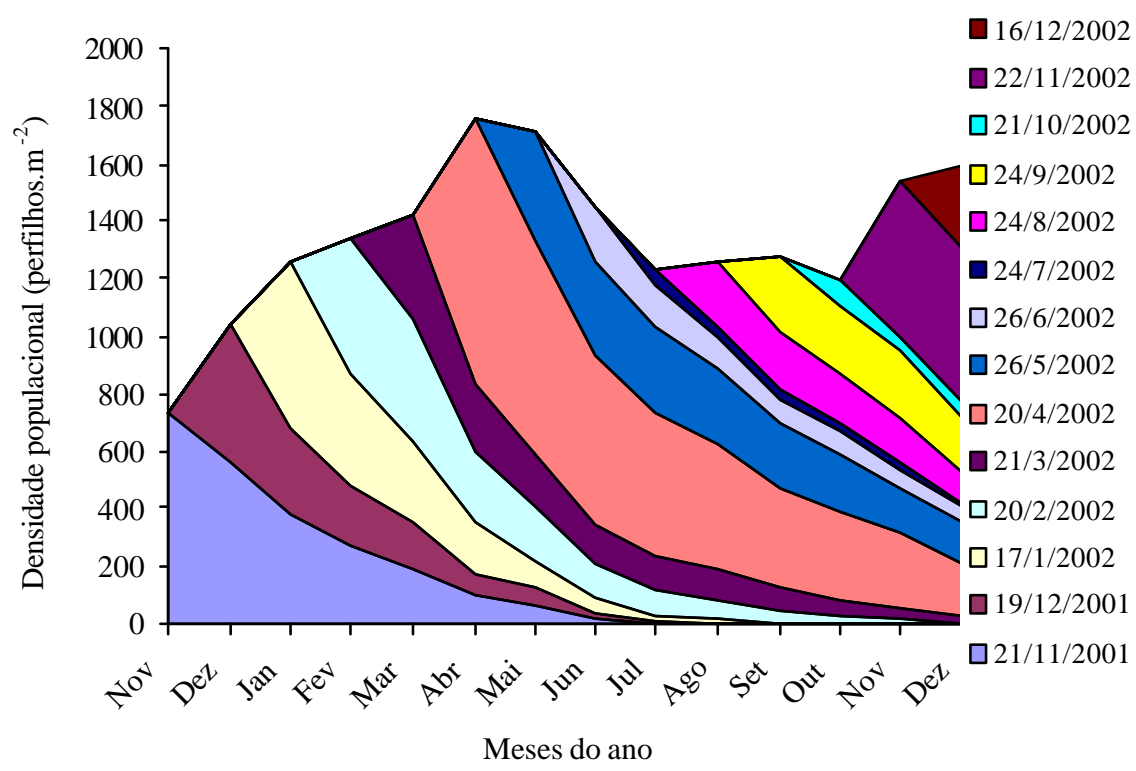

Figura 21 - Padrão demográfico do perfilhamento em pastos de capim-Marandu mantidos a $40 \mathrm{~cm}$ de altura do dossel forrageiro por bovinos em lotação contínua

As Figuras 22 a 25 ilustram a variação mensal nos índices de estabilidade das populações de perfilhos e as Figuras 26 a 29 demonstram a variação estacional dos mesmos índices. Observa-se que pastos mantidos a $10 \mathrm{~cm}$ apresentaram os menores índices de estabilidade para o período de verão, recuperando-se apenas nos meses de agosto e novembro. Já para pastos mantidos acima de $20 \mathrm{~cm}$, os meses de abril a julho apresentaram baixos índices de estabilidade. Uma característica comum a todas as condições de pasto analisadas foi a recuperação da estabilidade da população de perfilhos durante o período de final de primavera e, para os pastos mantidos a 30 e 40 cm, também durante o verão (Figuras 22 a 25). 


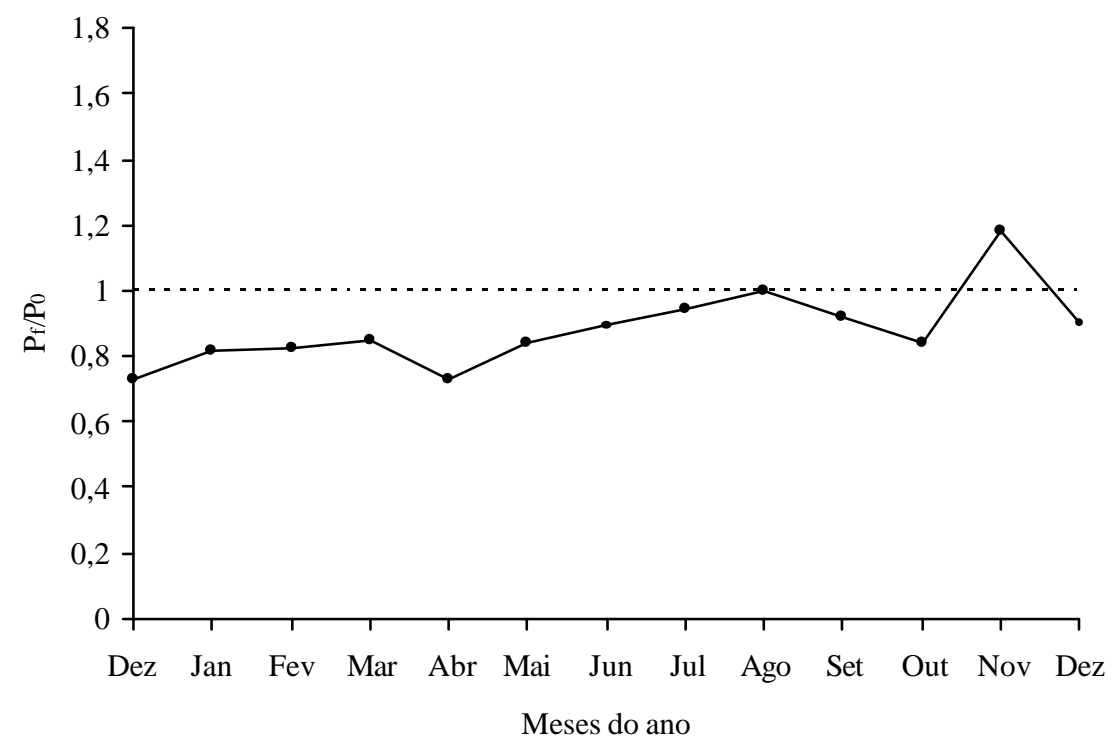

Figura 22 - Variações no índice populacional $\left(\mathrm{P}_{\mathrm{f}} / \mathrm{P}_{0}\right)$ em pastos de capim-Marandu mantidos a $10 \mathrm{~cm}$ de altura por bovinos de corte em lotação contínua

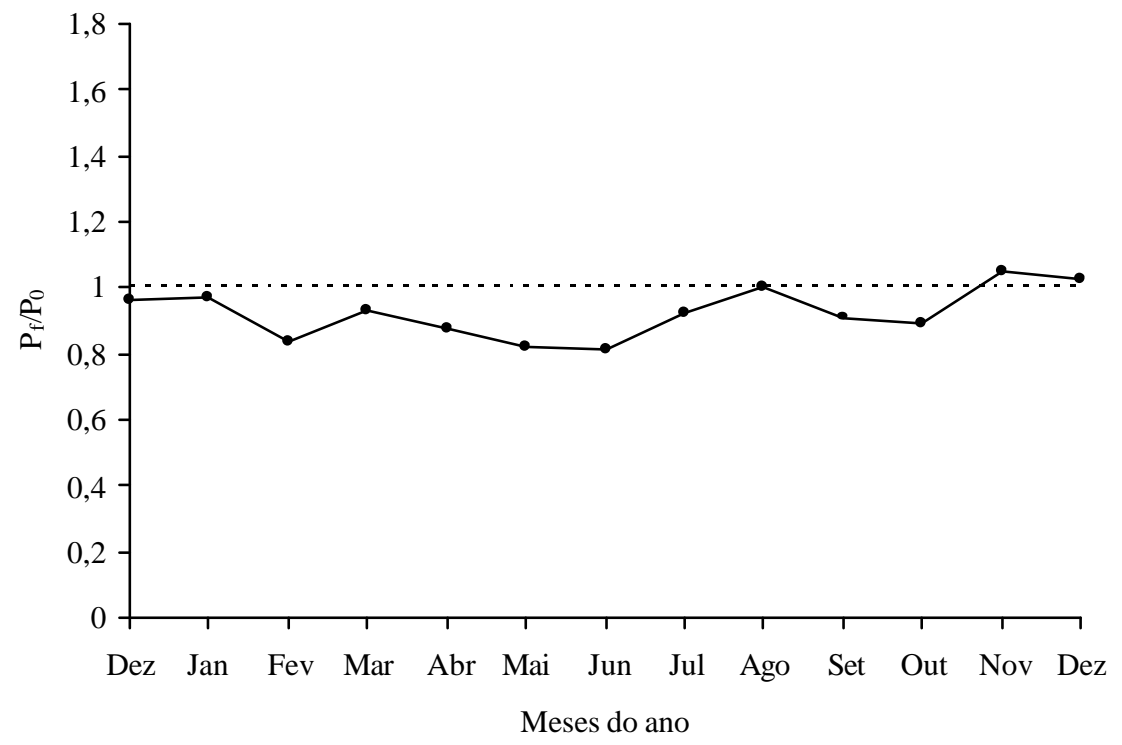

Figura 23 - Variações no índice populacional $\left(\mathrm{P}_{\mathrm{f}} / \mathrm{P}_{0}\right)$ em pastos de capim-Marandu mantidos a $20 \mathrm{~cm}$ de altura por bovinos de corte em lotação contínua 


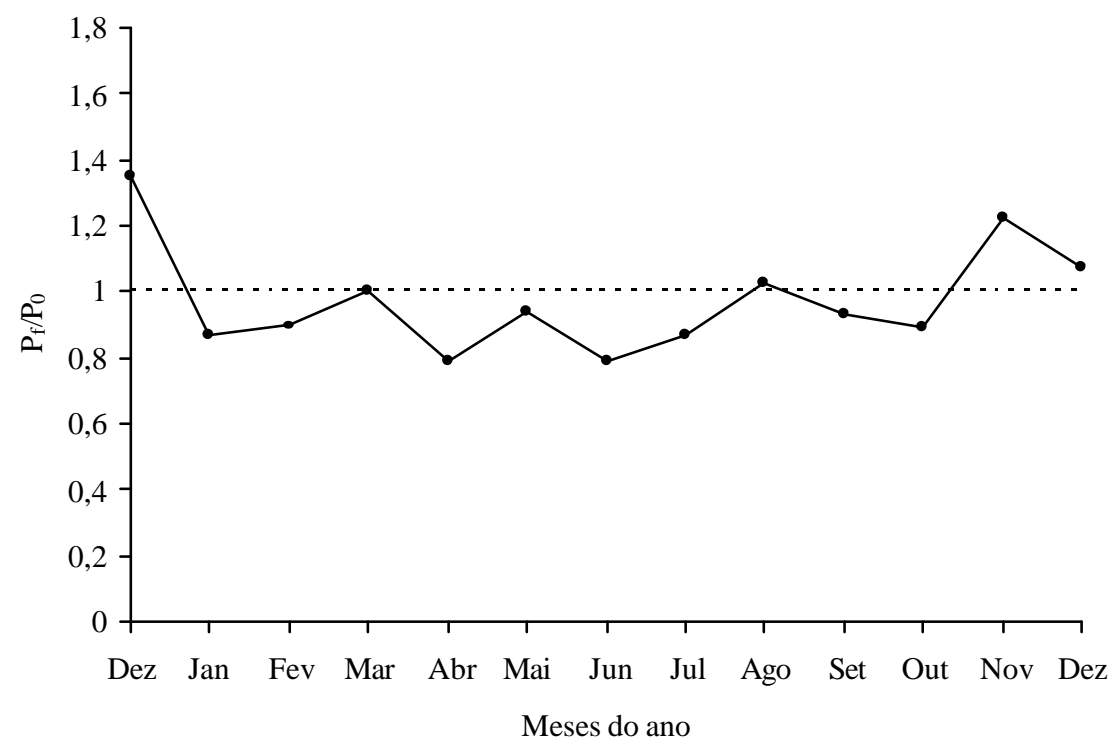

Figura 24 - Variações no índice populacional $\left(\mathrm{P}_{\mathrm{f}} / \mathrm{P}_{0}\right)$ em pastos de capim-Marandu mantidos a $30 \mathrm{~cm}$ de altura por bovinos de corte em lotação contínua

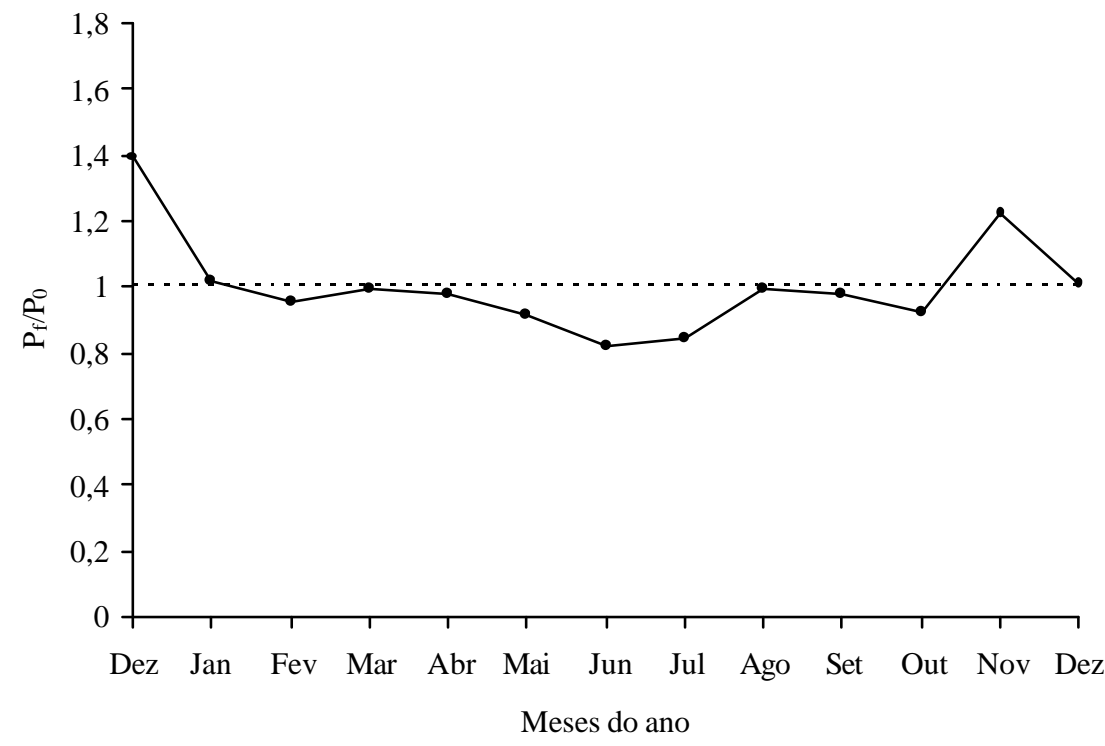

Figura 25 - Variações no índice populacional $\left(\mathrm{P}_{\mathrm{f}} / \mathrm{P}_{0}\right)$ em pastos de capim-Marandu mantidos a $40 \mathrm{~cm}$ de altura por bovinos de corte em lotação contínua 


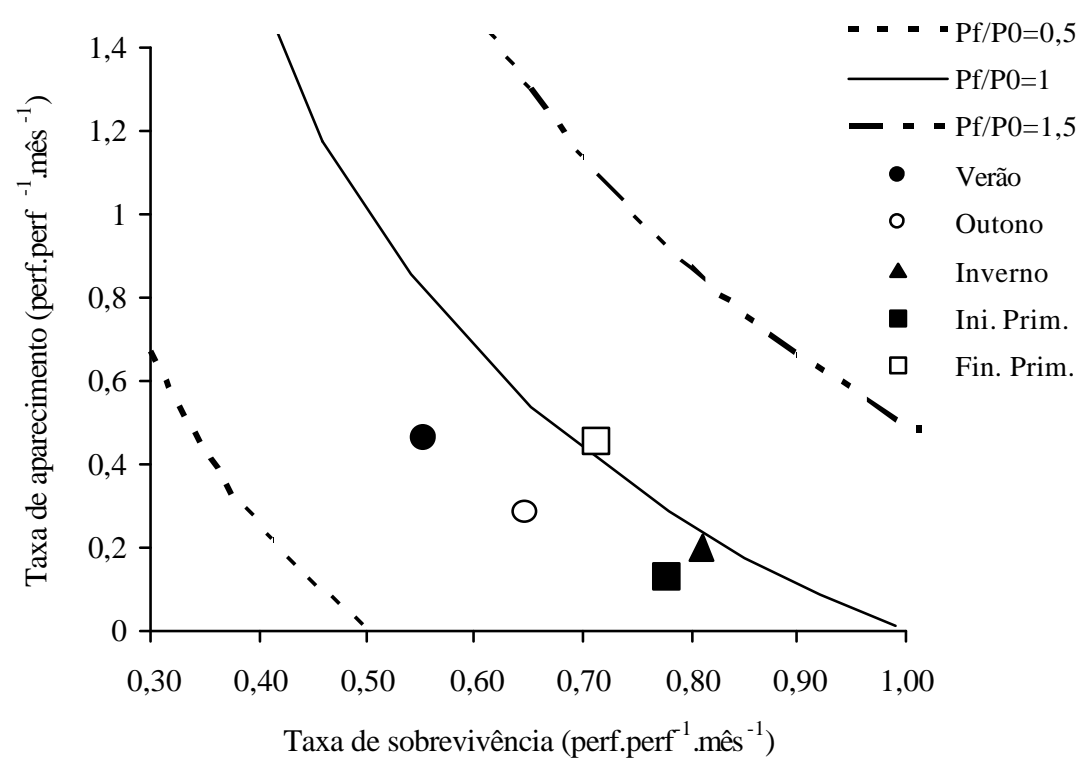

Figura 26 - Diagrama sazonal de estabilidade em pastos de capim-Marandu mantidos em $10 \mathrm{~cm}$ do dossel forrageiro por bovinos de corte em lotação contínua

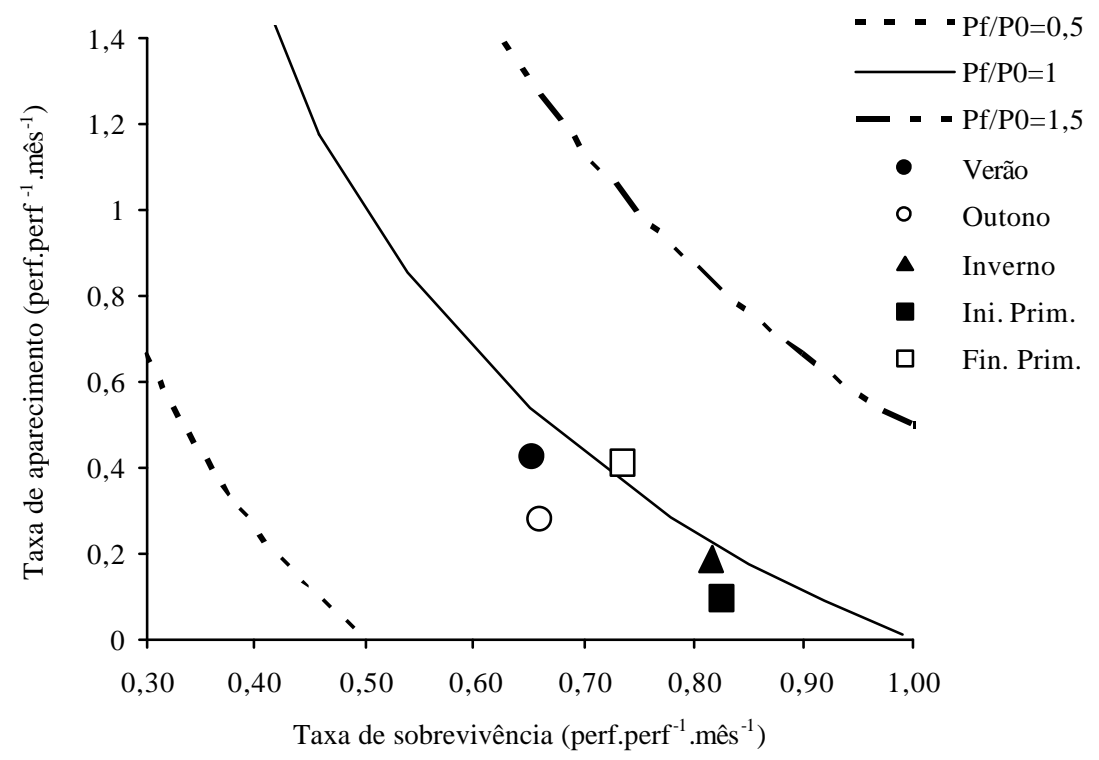

Figura 27 - Diagrama sazonal de estabilidade em pastos de capim-Marandu mantidos em $20 \mathrm{~cm}$ do dossel forrageiro por bovinos de corte em lotação contínua 


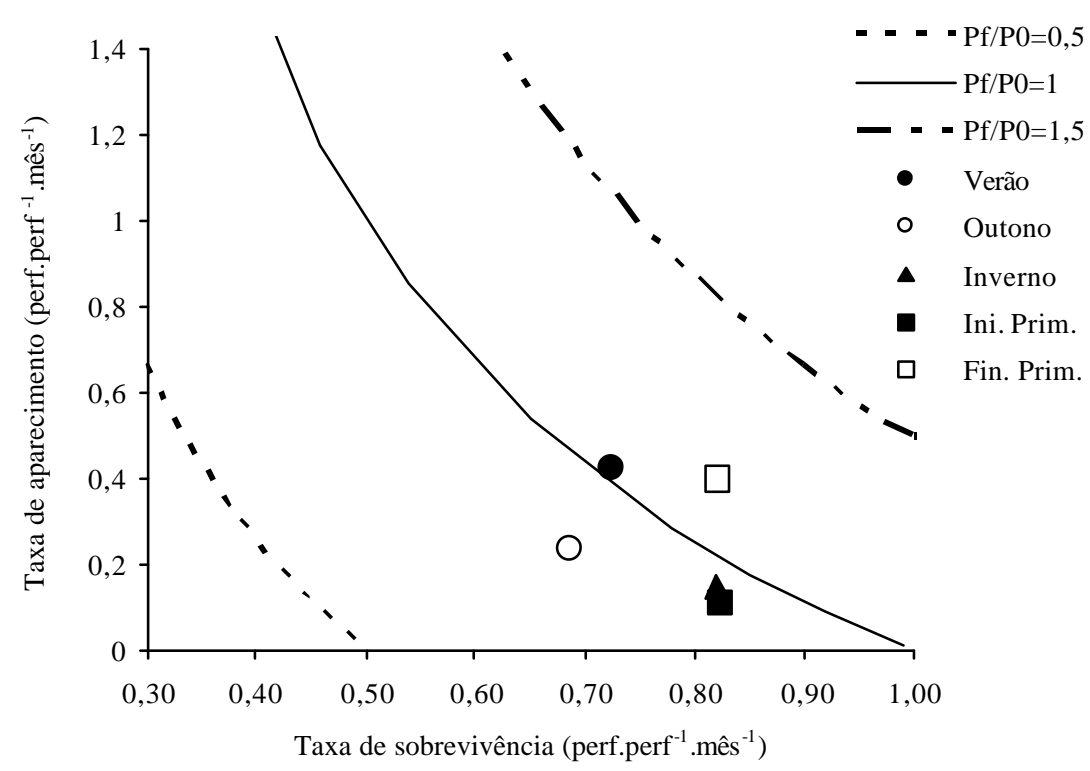

Figura 28 - Diagrama sazonal de estabilidade em pastos de capim-Marandu mantidos em $30 \mathrm{~cm}$ do dossel forrageiro por bovinos de corte em lotação contínua

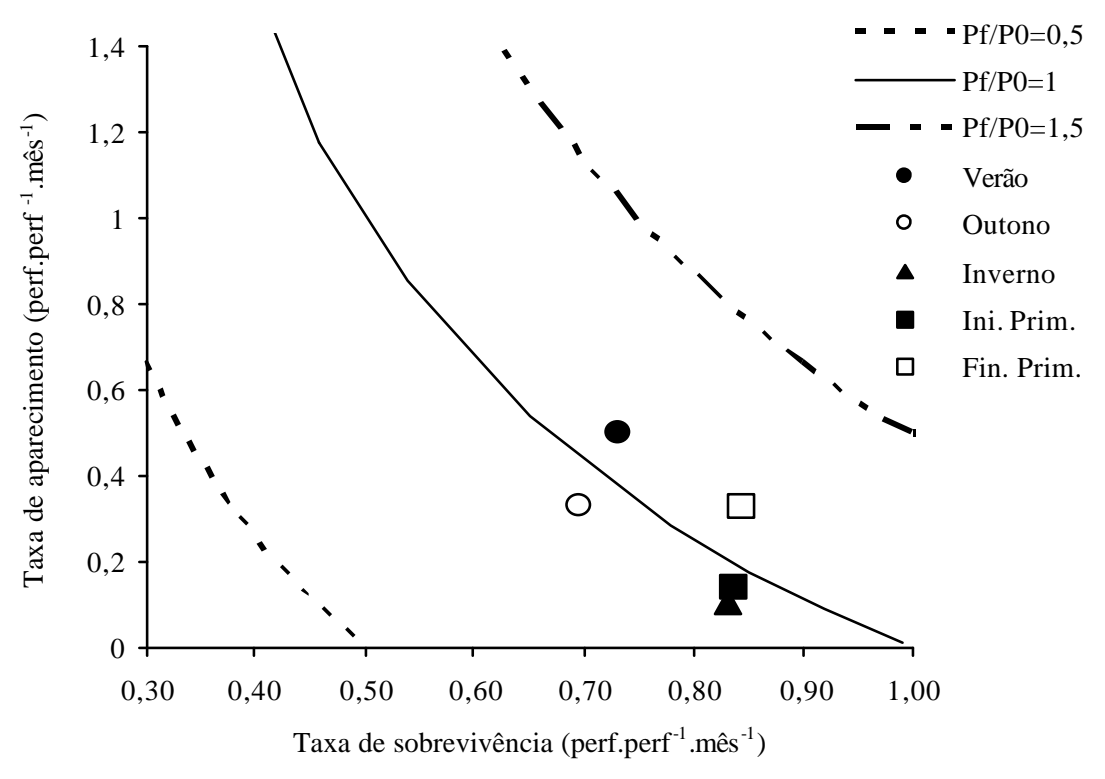

Figura 29 - Diagrama sazonal de estabilidade em pastos de capim-Marandu mantidos em $40 \mathrm{~cm}$ do dossel forrageiro por bovinos de corte em lotação contínua 


\subsection{Características de perfilhos individuais}

\subsection{1 Área foliar}

Houve efeito de altura do dossel $(\mathrm{P}<0,0001)$, época do ano $(\mathrm{P}<0,0001)$ e interação altura do dossel $\mathrm{x}$ época do ano $(\mathrm{P}<0,0001)$. Pastos mantidos a $40 \mathrm{~cm}$ apresentaram os valores mais altos de área foliar média por perfilho $\left(73,0 \mathrm{~cm}^{2}\right)$, sendo esses cerca de 2,8 vezes maiores que os valores mais baixos $\left(26 \mathrm{~cm}^{2}\right)$, obtidos em pastos mantidos a $10 \mathrm{~cm}$. Apesar de significativa, a variação em área foliar média por perfilho ao longo das épocas do ano foi pequena, exceção feita ao período de início de primavera, época em que foram registrados valores cerca de $40 \%$ inferiores àqueles das outras épocas do ano (Tabela 22)

Tabela 22. Área foliar média por perfilho $\left(\mathrm{cm}^{2}\right)$ em pastos de capim-Marandu mantidos em quatro alturas de dossel forrageiro por meio de lotação contínua em diferentes épocas do ano

\begin{tabular}{|c|c|c|c|c|c|c|c|c|c|c|c|}
\hline \multirow{2}{*}{$\begin{array}{c}\text { Epoca do } \\
\text { ano }\end{array}$} & \multicolumn{8}{|c|}{ Altura $(\mathrm{cm})$} & \multirow{2}{*}{\multicolumn{2}{|c|}{ Média }} & \multirow{2}{*}{$\mathrm{EPM}^{*}$} \\
\hline & \multicolumn{2}{|c|}{10} & \multicolumn{2}{|c|}{20} & \multicolumn{2}{|c|}{30} & \multicolumn{2}{|c|}{40} & & & \\
\hline Verão & 23,3 & $d A B$ & 47,2 & $\mathrm{cA}$ & 61,9 & $\mathrm{bB}$ & 75,2 & $\mathrm{aB}$ & 51,9 & B & 1,36 \\
\hline Outono & 31,1 & c A & 47,4 & $\mathrm{~b} \mathrm{AB}$ & 71,7 & $\mathrm{a} A$ & 84,3 & a A & 58,6 & A & 2,85 \\
\hline Inverno & 28,6 & c A & 38,9 & c ABC & 63,6 & $\mathrm{~b} A \mathrm{AB}$ & 77,4 & a $A B$ & 52,1 & B & 2,75 \\
\hline Ini. Prim. & 19,2 & c B & 32,2 & b C & 37,5 & $\mathrm{ab} C$ & 43,0 & $\mathrm{a} \mathrm{C}$ & 32,9 & C & 1,17 \\
\hline Fin. Prim. & 27,8 & d A & 36,7 & $\mathrm{c} \mathrm{BC}$ & 59,9 & b B & 78,5 & $\mathrm{a} A B$ & 50,7 & B & 1,46 \\
\hline Média $^{\dagger}$ & 26,0 & $\mathrm{~d}$ & 41,1 & $\mathrm{c}$ & 60,2 & $\mathrm{~b}$ & 73,0 & a & & & \\
\hline $\mathrm{EPM}^{*}$ & 2,57 & & 2,57 & & 2,57 & & 2,57 & & & & \\
\hline
\end{tabular}

Erro padrão da média

Erro padrão da média da interação: Verão=2,72, Outono=5,70, Inverno=5,50, Ini. Prim.=2,34 e Fin. Prim. $=2,96$

Médias seguidas da mesma letra minúscula na linha e maiúscula na coluna não diferem entre si $(\mathrm{P}>0,10)$

${ }^{\dagger}$ As médias das alturas correspondem à média de todos os meses do experimento 


\subsubsection{Massa}

Houve efeito de altura do dossel $(\mathrm{P}<0,0001)$, época do ano $(\mathrm{P}<0,0001)$ e interação altura do dossel $\mathrm{x}$ época do ano $(\mathrm{P}=0,0308)$. Os perfilhos mais pesados foram encontrados nos pastos mantidos a $40 \mathrm{~cm}$ (Tabela 23), padrão de resposta análogo àquele observado para a área foliar média por perfilho. No entanto, em relação às épocas do ano, os valores mais altos foram verificados durante o período de início de primavera e os menores durante o período de verão. Perfilhos no verão foram, em média, $30 \%$ mais leves $(760,3 \mathrm{mg})$ que perfilhos no início de primavera (1088,7 mg).

Tabela 23. Massa média por perfilho (mg) em pastos de capim-Marandu mantidos em quatro alturas de dossel forrageiro por meio de lotação contínua em diferentes épocas do ano

\begin{tabular}{|c|c|c|c|c|c|c|c|c|c|c|c|}
\hline \multirow{2}{*}{$\begin{array}{c}\text { Época do } \\
\text { ano }\end{array}$} & \multicolumn{8}{|c|}{ Altura $(\mathrm{cm})$} & \multirow{2}{*}{\multicolumn{2}{|c|}{ Média }} & \multirow{2}{*}{ EPM" } \\
\hline & \multicolumn{2}{|c|}{10} & \multicolumn{2}{|c|}{20} & \multicolumn{2}{|l|}{30} & \multicolumn{2}{|c|}{40} & & & \\
\hline Verão & 308,1 & $d e$ & 644,2 & c BC & 826,3 & $\mathrm{bD}$ & 1262,5 & $\mathrm{aB}$ & 760,3 & c & 20,19 \\
\hline Outono & 329,2 & $\mathrm{~d} \mathrm{C}$ & 585,6 & c C & 979,2 & b C & 1104,9 & $\mathrm{a} C$ & 749,7 & C & 21,77 \\
\hline Inverno & 385,2 & $\mathrm{~d} B C$ & 718,8 & $\mathrm{c} \mathrm{B}$ & 1181,5 & b B & 1347,6 & a B & 908,3 & B & 34,99 \\
\hline Ini. Prim. & 513,5 & $\mathrm{~d} A$ & 919,7 & c A & 1333,0 & b A & 1588,6 & a A & 1088,7 & A & 39,77 \\
\hline Fin. Prim. & 468,9 & $\mathrm{~d} A \mathrm{~B}$ & 647,2 & c BC & 1053,7 & b C & 1220,3 & a BC & 847,5 & B & 34,21 \\
\hline Média $^{\dagger}$ & 387,2 & d & 688,4 & c & 1046,0 & $\mathrm{~b}$ & 1298,0 & $\mathrm{a}$ & & & \\
\hline $\mathrm{EPM}^{*}$ & 22,78 & & 22,78 & & 22,78 & & 22,78 & & & & \\
\hline $\begin{array}{l}{ }^{*} \text { Erro padr } \\
\text { Erro padrãa } \\
\text { Prim.=68,4 } \\
\text { Médias seg } \\
\end{array}$ & $\begin{array}{l}\text { a média } \\
\text { média } \\
\text { s da m }\end{array}$ & da in & ção: & rão $=$ & Outon & & ver & 0 & . & & e Fin. \\
\hline
\end{tabular}

As Figuras 30 a 33 ilustram as participações percentuais de cada componente na formação da massa média por perfilho. Durante os períodos de verão e outono o componente material morto não foi separado individualmente, de tal forma que o mesmo ficou contido no componente haste. A partir da altura de $20 \mathrm{~cm}$ a haste foi o componente 
que mais contribuiu para a formação da massa do perfilho. Pastos mantidos a $10 \mathrm{~cm}$ tiveram uma contribuição maior de folhas na formação da massa dos perfilhos. Durante o inverno e início de primavera, pastos mantidos acima de $20 \mathrm{~cm}$ chegaram a ter $20-25 \%$ de sua massa representada por material morto. Esse percentual foi reduzido para menos de $15 \%$ durante o final da primavera para todas as alturas de dossel estudadas.

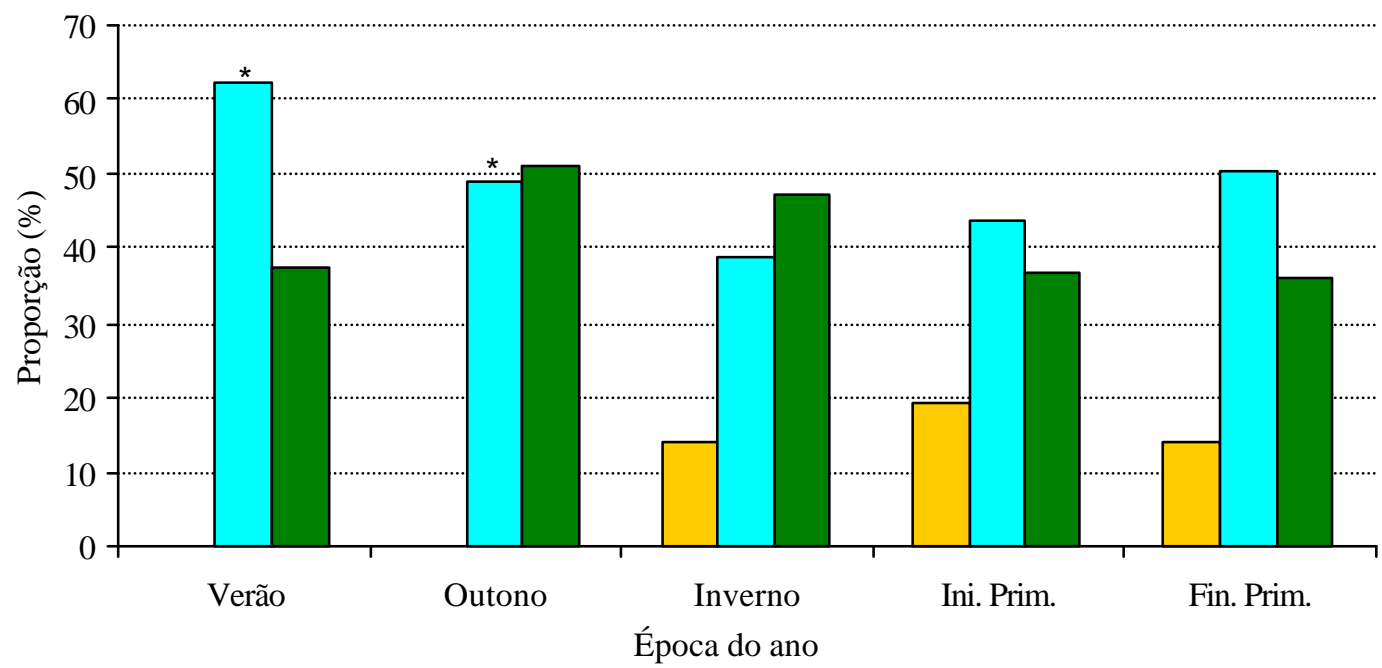

$\square$ Material Morto $\square$ Haste $\square$ Folha

Figura 30 - Contribuição de folhas, hastes e material morto na formação da massa média por perfilho em pastos de capim-Marandu mantidos a $10 \mathrm{~cm}$ de altura, em diferentes épocas do ano. * O componente material morto está contido no componente haste 


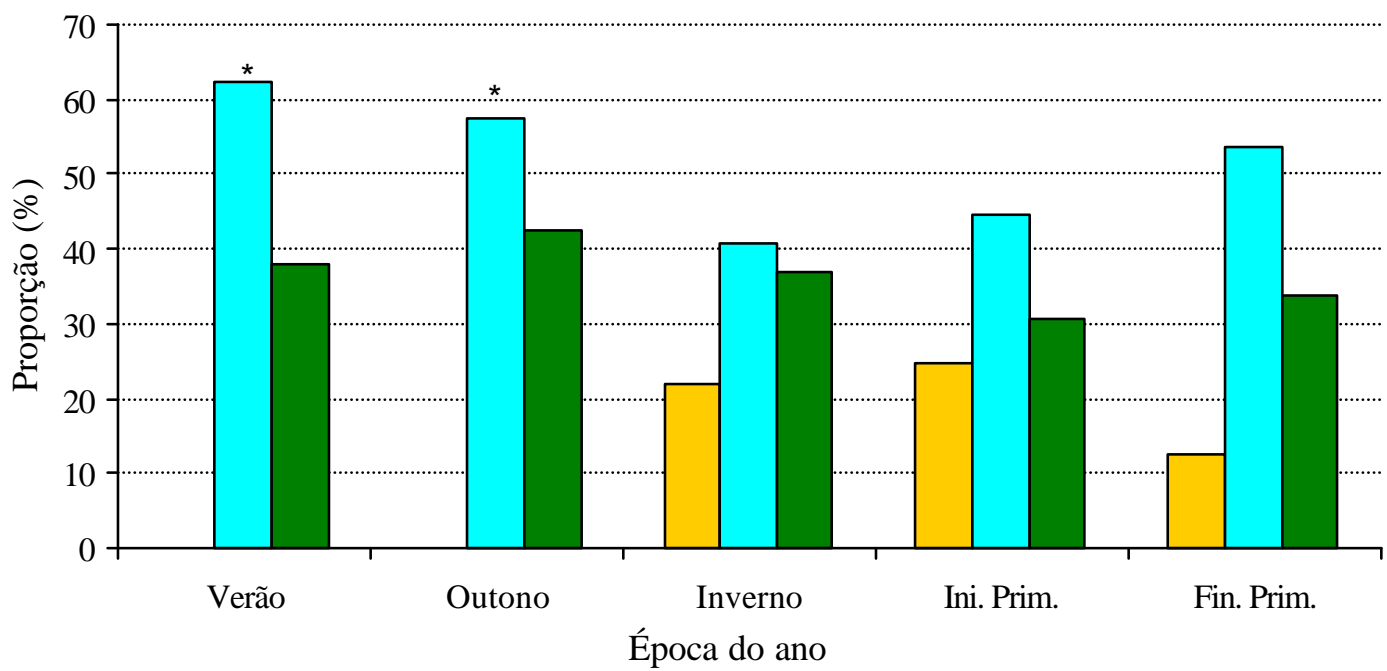

$\square$ Material Morto $\square$ Haste $\square$ Folha

Figura 31 - Contribuição de folhas, hastes e material morto na formação da massa média por perfilho em pastos de capim-Marandu mantidos a $20 \mathrm{~cm}$ de altura, em diferentes épocas do ano. $*$ O componente material morto está contido no componente haste

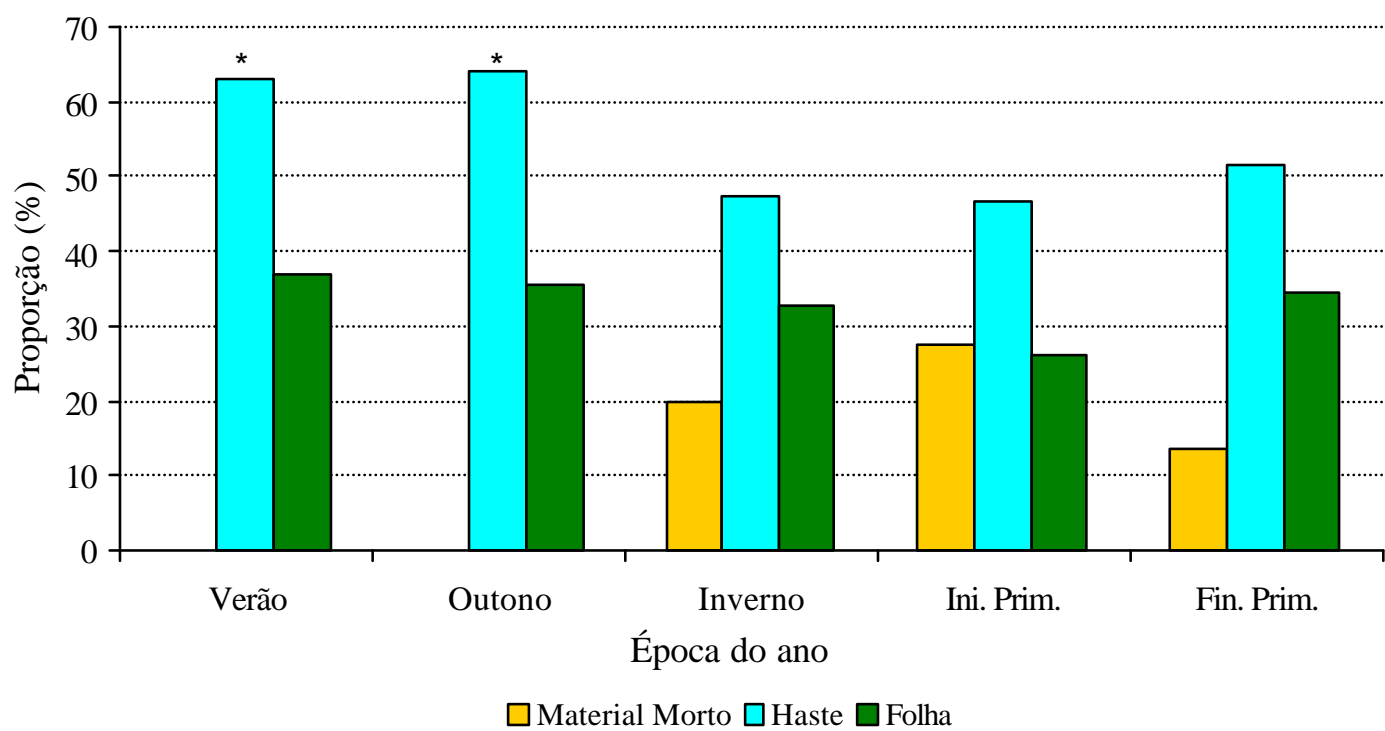

Figura 32 - Contribuição de folhas, hastes e material morto na formação da massa média por perfilho em pastos de capim-Marandu mantidos a $30 \mathrm{~cm}$ de altura, em diferentes épocas do ano. $*$ O componente material morto está contido no componente haste 


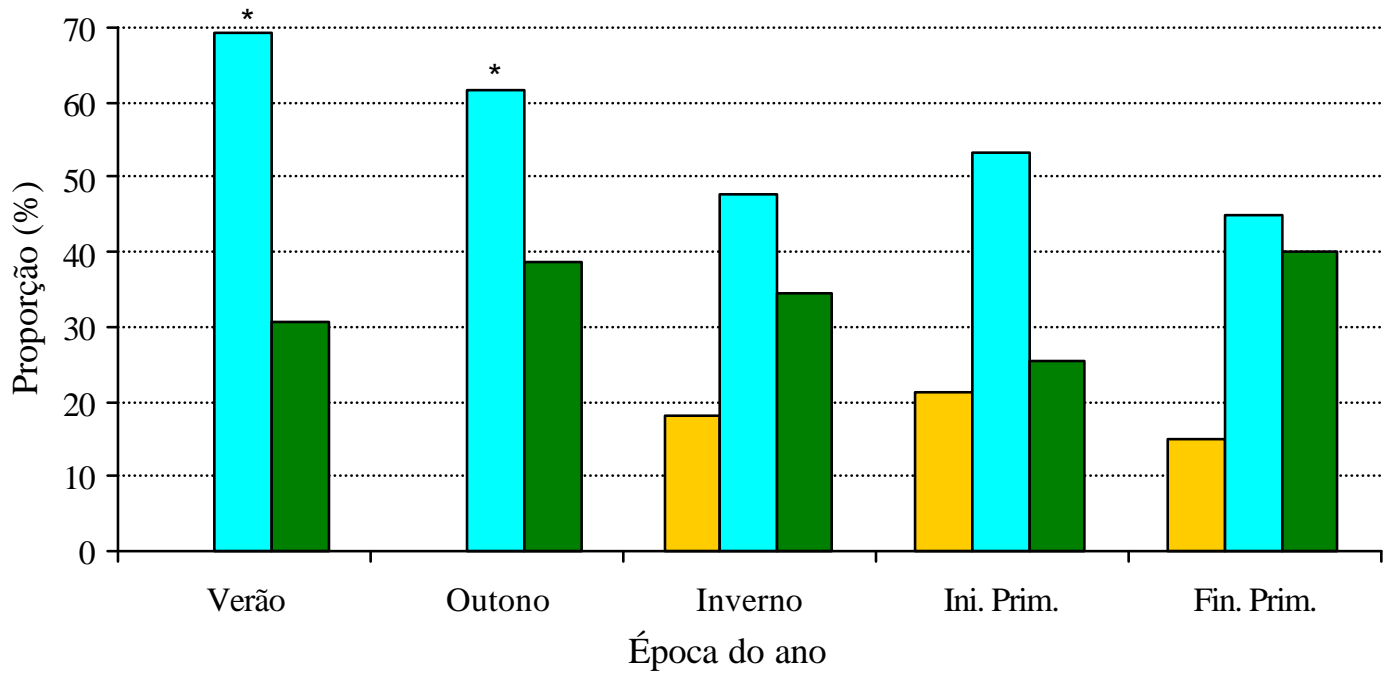

$\square$ Material Morto $\square$ Haste $\square$ Folha

Figura 33 - Contribuição de folhas, hastes e material morto na formação da massa média por perfilho em pastos de capim-Marandu mantidos a $40 \mathrm{~cm}$ de altura, em diferentes épocas do ano. $*$ O componente material morto está contido no componente haste

\subsection{3 Área foliar específica (AFE)}

A análise estatística revelou efeito apenas de época do ano para essa característica $(\mathrm{P}<0,0001)$. A média geral das alturas foi de $1,63 \mathrm{~cm}^{2} \cdot \mathrm{g}^{-1}$ de folha (Tabela 24). Em relação às épocas do ano, o maior valor foi encontrado durante o verão/outono $\left(1,97 \mathrm{~cm}^{-2} \cdot \mathrm{g}^{-1}\right)$ e o menor no início da primavera $\left(0,99 \mathrm{~cm}^{-2} \cdot \mathrm{g}^{-1}\right)$. 
Tabela 24. Área foliar específica $\left(\mathrm{cm}^{2} \cdot \mathrm{g}^{-1}\right)$ em pastos de capim-Marandu mantidos em quatro alturas de dossel forrageiro por meio de lotação contínua em diferentes épocas do ano

\begin{tabular}{cccccccc}
\hline $\begin{array}{c}\text { Epoca do } \\
\text { ano }\end{array}$ & \multicolumn{9}{c}{ Altura (cm) } & \multicolumn{2}{c}{ Média } & \multirow{2}{*}{ EPM $^{*}$} \\
\hline Verão & 20 & 20 & 30 & 40 & & & \\
Outono & 1,03 & 1,95 & 2,08 & 1,95 & 2,00 & A & 0,056 \\
Inverno & 1,59 & 1,48 & 1,63 & 1,51 & 1,55 & C & 0,080 \\
Ini. Prim. & 1,03 & 0,92 & 1,04 & 0,98 & 0,99 & D & 0,064 \\
Fin. Prim. & 1,64 & 1,69 & 1,64 & 1,69 & 1,67 & B & 0,048 \\
Média $^{\dagger}$ & 1,63 & 1,59 & 1,69 & 1,61 & & & \\
EPM $^{*}$ & 0,044 & 0,044 & 0,044 & 0,044 & & & \\
\hline
\end{tabular}

Erro padrão da média

Médias seguidas da mesma letra minúscula na linha e maiúscula na coluna não diferem entre si $(\mathrm{P}>0,10)$

${ }^{\dagger}$ As médias das alturas correspondem à média de todos os meses do experimento

\subsubsection{Volume e densidade aparente}

Para os valores de volume de perfilhos individuais foram encontrados efeitos de altura do dossel $(\mathrm{P}<0,0001)$ e de época do ano $(\mathrm{P}<0,0001)$. Os maiores valores foram registrados em pastos mantidos a $40 \mathrm{~cm}\left(5,24 \mathrm{~cm}^{3}\right)$ e os menores em pastos mantidos a $10 \mathrm{~cm}\left(1,88 \mathrm{~cm}^{3}\right)$. Em relação às épocas do ano, os maiores valores foram registrados no final da primavera $\left(4,11 \mathrm{~cm}^{3}\right)$ e os menores durante o inverno e início de primavera $(3,23$ $\mathrm{cm}^{3}$, em média) (Tabela 25).

Com relação à densidade aparente de perfilhos individuais, foi detectado efeito de altura do dossel $(\mathrm{P}=0,0457)$ e época do ano $(\mathrm{P}<0,0001)$. Perfilhos de pastos mantidos a 20, 30 e $40 \mathrm{~cm}$ não diferiram entre si e foram mais densos $\left(972 \mathrm{~kg} \cdot \mathrm{m}^{-3}\right.$, em média) que os perfilhos dos pastos mantidos a $10 \mathrm{~cm}\left(921 \mathrm{~kg} \cdot \mathrm{m}^{-3}\right)$. Os maiores valores de densidade aparente foram registrados durante o período de inverno/início de primavera (1003 
$\mathrm{kg} \cdot \mathrm{m}^{-3}$, em média) comparativamente àqueles do período de final de primavera (870 kg. $\mathrm{m}^{-3}$ ) (Tabela 26).

Tabela 25. Volume de perfilhos individuais $\left(\mathrm{cm}^{3}\right)$ em pastos de capim-Marandu mantidos em quatro alturas de dossel forrageiro por meio de lotação contínua em diferentes épocas do ano

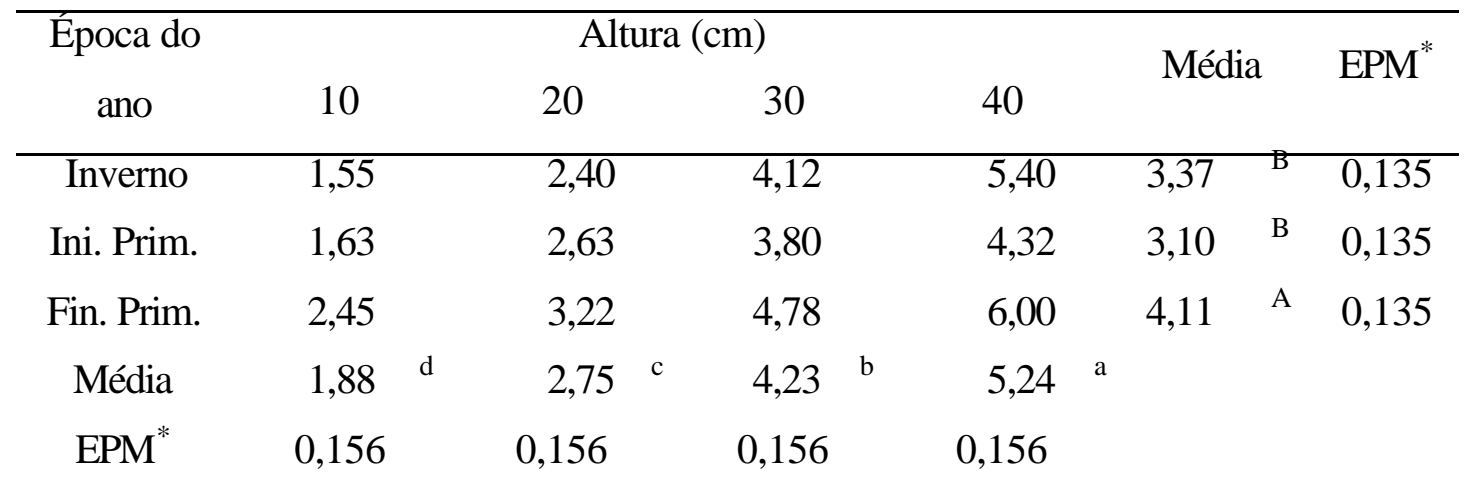

"Erro padrão da média

Médias seguidas da mesma letra minúscula na linha e maiúscula na coluna não diferem entre si $(\mathrm{P}>0,10)$

Tabela 26. Densidade aparente de perfilhos individuais (kg. $\mathrm{m}^{-3}$ de massa verde) em pastos de capim-Marandu mantidos em quatro alturas de dossel forrageiro por meio de lotação contínua em diferentes épocas do ano

\begin{tabular}{ccrrrrrrr}
\hline $\begin{array}{c}\text { Epoca do } \\
\text { ano }\end{array}$ & 10 & 20 & 30 & 40 & Média & EPM $^{*}$ \\
\hline Inverno & 994 & 1018 & 1036 & 1020 & 1017 & A & 16,0 \\
Ini. Prim. & 944 & 987 & 962 & 1069 & 990 & A & 16,4 \\
Fin. Prim. & 825 & 888 & 882 & 886 & 870 & B & 16,5 \\
Média & $921 \quad$ b & 964 a & 960 a & 992 & a & & & \\
EPM & 14,3 & 12,9 & 15,7 & 14,6 & & & \\
\end{tabular}

"Erro padrão da média

Médias seguidas da mesma letra minúscula na linha e maiúscula na coluna não diferem entre si $(\mathrm{P}>0,10)$ 


\subsubsection{Relação folha: haste e razão área foliar: volume $(\mathbf{R})$}

Para a relação folha: haste $(\mathrm{FH})$, houve efeito de altura do dossel $(\mathrm{P}<0,0001)$, época do ano $(\mathrm{P}<0,0001)$ e interação altura do dossel $\mathrm{x}$ época do ano $(\mathrm{P}=0,0008)$. A maior relação FH foi registrada nos pastos mantidos a $10 \mathrm{~cm}(1,02)$ e a menor nos pastos mantidos a 30 e $40 \mathrm{~cm}$ (cerca de 0,60) (Tabela 27). Em relação às épocas do ano, as maiores relações FH foram mensuradas durante o período de inverno $(0,89)$ e as menores no verão e final de primavera, que apresentaram um valor médio de 0,66.

Tabela 27. Relação folha: haste em pastos de capim-Marandu mantidos em quatro alturas de dossel forrageiro por meio de lotação contínua em diferentes épocas do ano

\begin{tabular}{|c|c|c|c|c|c|c|c|c|c|c|c|}
\hline \multirow{2}{*}{$\begin{array}{c}\text { Época do } \\
\text { ano }\end{array}$} & \multicolumn{8}{|c|}{ Altura $(\mathrm{cm})$} & \multirow{2}{*}{\multicolumn{2}{|c|}{ Média }} & \multirow{2}{*}{ EPM* } \\
\hline & \multicolumn{2}{|c|}{10} & \multicolumn{2}{|c|}{20} & \multicolumn{2}{|c|}{30} & \multicolumn{2}{|c|}{40} & & & \\
\hline Verão & 0,77 & $\mathrm{aC}$ & 0,66 & $\mathrm{aB}$ & 0,64 & $\mathrm{aA}$ & 0,46 & bB & 0,63 & C & 0,035 \\
\hline Outono ${ }^{\ddagger}$ & 1,12 & a B & 0,81 & $\mathrm{~b} A \mathrm{AB}$ & 0,58 & $\mathrm{cA}$ & 0,59 & $\mathrm{c} A \mathrm{~B}$ & 0,77 & B & 0,035 \\
\hline Inverno & 1,39 & a A & 0,86 & $\mathrm{~b} A$ & 0,65 & $\mathrm{cA}$ & 0,68 & $\mathrm{cA}$ & 0,89 & A & 0,035 \\
\hline Ini. Prim. & 1,14 & a B & 0,75 & $\mathrm{~b} A B$ & 0,57 & $\mathrm{cA}$ & 0,52 & c AB & 0,75 & B & 0,035 \\
\hline Fin. Prim. & 0,78 & $\mathrm{aC}$ & 0,66 & a B & 0,71 & a A & 0,64 & a A & 0,70 & C & 0,035 \\
\hline Média $^{\dagger}$ & 1,02 & a & 0,75 & $\mathrm{~b}$ & 0,63 & $\mathrm{c}$ & 0,58 & $\mathrm{c}$ & & & \\
\hline $\mathrm{EPM}^{*}$ & 0,029 & & 0,030 & & 0,030 & & 0,032 & & & & \\
\hline
\end{tabular}

"Erro padrão da média

Erro padrão da média da interação: 0,070.

Médias seguidas da mesma letra minúscula na linha e maiúscula na coluna não diferem entre si $(\mathrm{P}>0,10)$

$\dagger$ As médias das alturas correspondem à média de todos os meses do experimento

$\ddagger$ O componente material morto está contido no componente haste

Para a variável razão área foliar: volume $(\mathrm{R})$, calculada com base nos volumes de perfilhos estimados a partir de uma densidade aparente e constante de $950 \mathrm{~kg} . \mathrm{m}^{-3}$, houve efeito de altura do dossel $(\mathrm{P}=0,0005)$, época do ano $(\mathrm{P}<0,0001)$ e interação altura do dossel $\mathrm{x}$ época do ano $(\mathrm{P}<0,0001)$. Os maiores valores foram registrados em pastos 
mantidos a $40 \mathrm{~cm}$, que apresentaram um valor de $\mathrm{R}$ igual a 102,7 . No outro extremo, pastos mantidos a $10 \mathrm{~cm}$ apresentaram os menores valores $(70,2)$. Em relação às épocas do ano, os maiores valores foram registrados durante o período de outono $(109,7)$ e os menores durante o início de primavera $(55,6)$ (Tabela 28).

Tabela 28. Razão área foliar: volume por perfilho, assumindo volume calculado baseado em densidade constante de $950 \mathrm{~kg} \cdot \mathrm{m}^{-3}$, em pastos de capim-Marandu mantidos em quatro alturas de dossel forrageiro por meio de lotação contínua em diferentes épocas do ano

\begin{tabular}{ccccccccccccc}
\hline $\begin{array}{c}\text { Época do } \\
\text { ano }\end{array}$ & \multicolumn{9}{c}{10} & \multicolumn{9}{c}{ Altura (cm) } & \multicolumn{2}{c}{30} & & & & Média & \multirow{2}{*}{ EPM $^{*}$} \\
\hline Verão & 64,0 & b B & 82,6 & a B & 94,1 & a BC & 93,2 & a B & 83,5 & C & 2,73 \\
Outono & 88,8 & c A & 108,5 & b A & 117,3 & ab A & 124,3 & a A & 109,7 & A & 3,22 \\
Inverno & 85,5 & c A & 87,8 & bc B & 110,6 & ab AB & 117,5 & a A & 100,3 & B & 4,90 \\
Ini. Prim. & 51,3 & ab B & 65,5 & a C & 46,0 & b D & 59,7 & ab C & 55,6 & D & 3,21 \\
Fin. Prim. & 58,0 & d B & 68,2 & c C & 93,8 & b C & 115,7 & a A & 83,9 & C & 1,86 \\
Média & 70,2 & d & 83,2 & c & 95,9 & a & 102,7 & a & & & \\
EPM $^{*}$ & 3,04 & & 2,99 & & 3,12 & & 3,14 & & & & \\
\hline
\end{tabular}

"Erro padrão da média

Erro padrão da média da interação: Verão=5,46, Outono=6,44, Inverno=9,80, Ini. Prim.=6,42 e Fin. Prim. $=3,72$.

Médias seguidas da mesma letra minúscula na linha e maiúscula na coluna não diferem entre si $(\mathrm{P}>0,10)$

${ }^{\dagger}$ As médias das alturas correspondem à média de todos os meses do experimento

Quando os valores de $\mathrm{R}$ foram calculados com base no volume efetivo dos perfilhos, foi detectado efeito de altura do dossel $(\mathrm{P}=0,0657)$, época do ano $(\mathrm{P}<0,0001)$ e interação altura do dossel $\mathrm{x}$ época do ano $(\mathrm{P}=0,0226)$. Os maiores valores foram registrados nos pastos mantidos a 20,30 e $40 \mathrm{~cm}$, que apresentaram, em média, valores de $\mathrm{R}$ em torno de 90,2. Pastos mantidos a $10 \mathrm{~cm}$ apresentaram os menores valores $(67,1)$. Em relação às épocas do ano, os valores mais altos foram registrados durante o período de inverno $(106,7)$ e os mais baixos no início da primavera $(63,8)$ (Tabela 29). 
Tabela 29. Razão área foliar: volume por perfilho, calculada com os valores de volume efetivamente medidos, em pastos de capim-Marandu mantidos em quatro alturas de dossel forrageiro por meio de lotação contínua em diferentes épocas do ano.

\begin{tabular}{cccccccccccc}
\hline $\begin{array}{c}\text { Epoca do } \\
\text { ano }\end{array}$ & \multicolumn{9}{c}{10} & \multicolumn{9}{c}{ Altura (cm) } & \multicolumn{2}{c}{ Média } & \multirow{2}{*}{ EPM $^{*}$} \\
\hline Inverno & 82,8 & b A & 104,0 & ab A & 113,8 & a A & 126,3 & a A & 106,7 & A & 5,69 \\
Ini. Prim. & 57,2 & a B & 78,8 & a B & 62,4 & a C & 57,1 & a C & 63,8 & C & 5,57 \\
Fin. Prim. & 61,3 & b B & 69,2 & b B & 97,0 & a B & 103,9 & a B & 82,9 & B & 2,25 \\
Média & 67,1 & b & 84,0 & ab & 91,0 & a & 95,8 & a & & & \\
EPM & 6,77 & & 6,77 & & 6,77 & & 6,77 & & & & \\
\hline
\end{tabular}

Erro padrão da média

Erro padrão da média da interação: Inverno=11,38, Ini. Prim.=11,14 e Fin. Prim.=4,50.

Médias seguidas da mesma letra minúscula na linha e maiúscula na coluna não diferem entre si $(\mathrm{P}>0,10)$

\section{4 Índice de área foliar do dossel (IAF)}

Houve efeito de altura do dossel $(\mathrm{P}<0,0001)$, época do ano $(\mathrm{P}<0,0001)$ e interação altura do dossel x época do ano $(\mathrm{P}=0,0010)$. Os maiores valores de IAF foram mensurados nos pastos mantidos a 30 e $40 \mathrm{~cm}$, média de 4,9. Em nenhuma época do ano o IAF dos pastos de $40 \mathrm{~cm}$ foi superior àquele dos de $30 \mathrm{~cm}$. Os valores mais elevados de IAF foram registrados durante o período de verão e outono $(5,4)$ e os mais baixos durante o início de primavera $(2,2)$ (Tabela 30 e Figura 34). 
Tabela 30. Índice de área foliar de pastos de capim-Marandu mantidos em quatro alturas de dossel forrageiro por meio de lotação contínua em diferentes épocas do ano

\begin{tabular}{|c|c|c|c|c|c|c|c|c|c|c|c|}
\hline \multirow{2}{*}{$\begin{array}{c}\text { Época do } \\
\text { ano }\end{array}$} & \multicolumn{8}{|c|}{ Altura $(\mathrm{cm})$} & \multirow{2}{*}{\multicolumn{2}{|c|}{ Média }} & \multirow{2}{*}{ EPM } \\
\hline & \multicolumn{2}{|c|}{10} & \multicolumn{2}{|c|}{20} & \multicolumn{2}{|c|}{30} & \multicolumn{2}{|c|}{40} & & & \\
\hline Verão & 3,0 & $\mathrm{CAB}$ & 5,6 & $\mathrm{DA}$ & 6,6 & $\mathrm{ab} \mathrm{A}$ & 6,7 & $a A$ & 5,5 & A & 0,19 \\
\hline Outono & 3,4 & $\mathrm{cA}$ & 4,8 & b A & 6,7 & a A & 6,2 & a A & 5,3 & A & 0,24 \\
\hline Inverno & 2,7 & b B & 3,4 & $\mathrm{ab} B$ & 4,2 & a B & 4,0 & a C & 3,5 & B & 0,23 \\
\hline Ini. Prim. & 1,8 & c C & 2,3 & ab C & 2,6 & $\mathrm{aC}$ & 2,1 & b D & 2,2 & $\mathrm{C}$ & 0,07 \\
\hline Fin. Prim. & 2,7 & $\mathrm{~b} A \mathrm{AB}$ & 3,2 & b B & 5,0 & a B & 5,0 & a B & 4,0 & B & 0,20 \\
\hline Média $^{\dagger}$ & 2,7 & c & 4,0 & $\mathrm{~b}$ & 5,3 & $\mathrm{a}$ & 5,1 & a & & & \\
\hline EPM $^{*}$ & 0,21 & & 0,20 & & 0,20 & & 0,20 & & & & \\
\hline
\end{tabular}

Erro padrão da média

Erro padrão da média da interação: Verão=0,38, Outono=0,48, Inverno=0,46, Ini. Prim.=0,14 e Fin. Prim. $=0,40$.

Médias seguidas da mesma letra minúscula na linha e maiúscula na coluna não diferem entre si $(\mathrm{P}>0,10)$

${ }^{\dagger}$ As médias das alturas correspondem à média de todos os meses do experimento

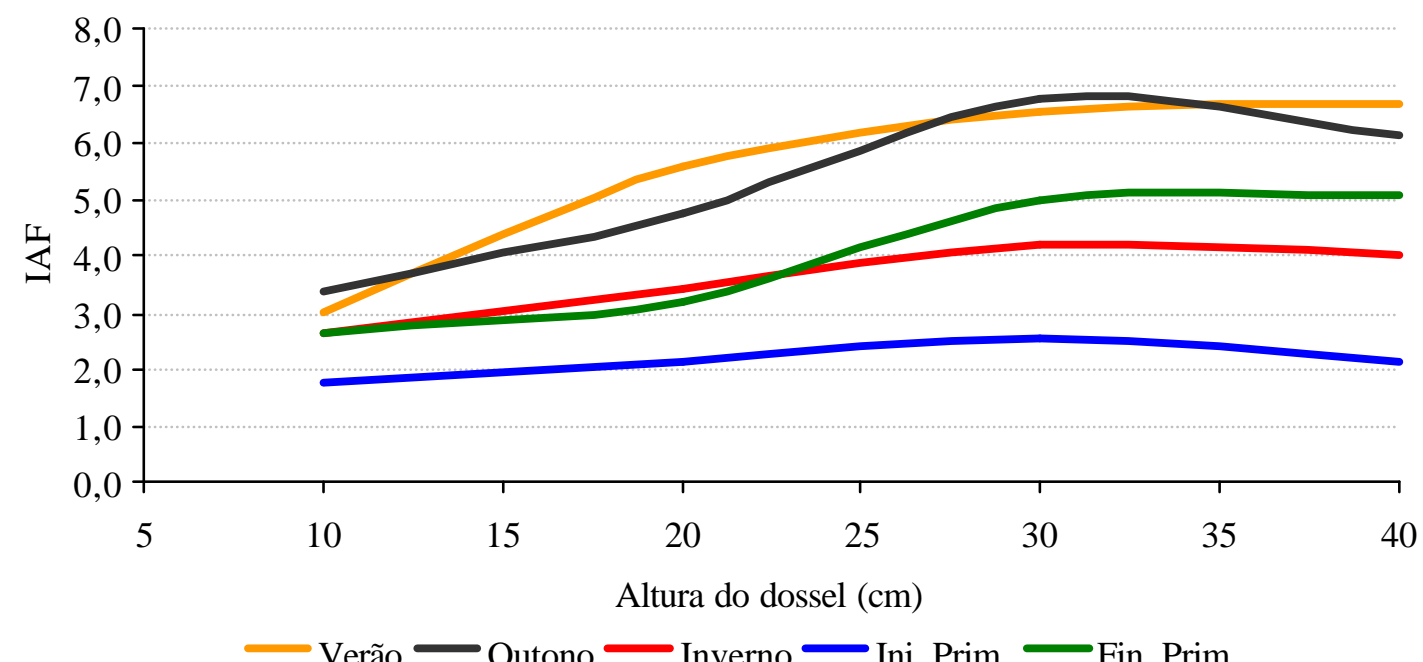

Figura 34 - Índice de área foliar em pastos de capim-Marandu submetidos a lotação contínua de Janeiro a Dezembro de 2002 


\subsection{Dinâmica do acúmulo}

\subsubsection{Taxas de alongamento, senescência e remoção de folhas}

Para a taxa de alongamento de folhas (TAlF) foi verificado efeito de altura do dossel $(\mathrm{P}=0,007)$, época do ano $(\mathrm{P}<0,0001)$ e interação altura do dossel $\mathrm{x}$ época do ano $(\mathrm{P}<0,0001)$. Folhas em expansão nos pastos mantidos a 30 e $40 \mathrm{~cm}$ apresentaram as maiores taxas de alongamento (0,94 cm.perfilho ${ }^{-1} \cdot \mathrm{dia}^{-1}$, em média). Esse valor foi cerca de $38 \%$ superior àquele observado para os pastos de $10 \mathrm{~cm}$, nos quais foram mensurados os menores valores $\left(0,68 \mathrm{~cm}\right.$.perfilho $\left.{ }^{-1} \cdot \mathrm{dia}^{-1}\right)$. As maiores TAlF foram registradas durante o período de verão $\left(1,24 \mathrm{~cm} \cdot\right.$ perfilho $\left.^{-1} \cdot \mathrm{dia}^{-1}\right)$, seguidas pelas de final da primavera $\left(1,14 \mathrm{~cm} \cdot\right.$ perfilho $\left.{ }^{-1} \cdot \mathrm{dia}^{-1}\right)$.

Tabela 31. Taxa de alongamento de folhas (cm.perfilho ${ }^{-1} \cdot \mathrm{dia}^{-1}$ ) em pastos de capimMarandu mantidos em quatro alturas de dossel forrageiro por meio de lotação contínua em diferentes épocas do ano

\begin{tabular}{|c|c|c|c|c|c|c|c|c|c|c|c|}
\hline \multirow{2}{*}{$\begin{array}{c}\text { Epoca do } \\
\text { ano }\end{array}$} & \multicolumn{8}{|c|}{ Altura $(\mathrm{cm})$} & \multirow{2}{*}{\multicolumn{2}{|c|}{ Média }} & \multirow{2}{*}{$\mathrm{EPM}^{*}$} \\
\hline & \multicolumn{2}{|c|}{10} & \multicolumn{2}{|c|}{20} & \multicolumn{2}{|c|}{30} & \multicolumn{2}{|c|}{40} & & & \\
\hline Verão & 0,95 & $\mathrm{cA}$ & 1,21 & $\mathrm{bA}$ & 1,48 & $\mathrm{a} A$ & 1,34 & $\mathrm{ab} B$ & 1,24 & A & 0,036 \\
\hline Outono & 0,58 & a B & 0,49 & a C & 0,60 & a B & 0,49 & $\mathrm{aC}$ & 0,54 & $\mathrm{C}$ & 0,036 \\
\hline Inverno & 0,43 & a B & 0,35 & $\mathrm{a} C D$ & 0,48 & a B & 0,42 & $\mathrm{aC}$ & 0,42 & D & 0,036 \\
\hline Ini. Prim. & 0,20 & $\mathrm{aC}$ & 0,20 & $\mathrm{a} D$ & 0,24 & a C & 0,25 & $\mathrm{a} \mathrm{D}$ & 0,22 & E & 0,036 \\
\hline Fin. Prim. & 0,79 & $\mathrm{c} \mathrm{A}$ & 0,85 & c B & 1,38 & b A & 1,56 & a A & 1,14 & B & 0,036 \\
\hline Média $^{\dagger}$ & 0,68 & $\mathrm{~b}$ & 0,75 & $\mathrm{~b}$ & 0,97 & a & 0,90 & $\mathrm{a}$ & & & \\
\hline EPM $^{*}$ & 0,038 & & 0,038 & & 0,038 & & 0,038 & & & & \\
\hline
\end{tabular}

Erro padrão da média

Erro padrão da média da interação $=0,072$

Médias seguidas da mesma letra minúscula na linha e maiúscula na coluna não diferem entre si $(\mathrm{P}>0,10)$

${ }^{\dagger}$ As médias das alturas correspondem à média de todos os meses do experimento

Esses valores foram cerca de seis vezes superiores àqueles registrados durante $\mathrm{o}$ período de início de primavera $\left(0,22 \mathrm{~cm} \cdot\right.$ perfilho $\left.^{-1} \cdot \mathrm{dia}^{-1}\right)$. Durante os períodos de outono, 
inverno e início de primavera não foram detectadas variações nas TAlF para as condições de dossel estudadas (Tabela 31).

Para a taxa de senescência foliar (TSF), foi detectado efeito de altura do dossel $(\mathrm{P}<0,0001)$, época do ano $(\mathrm{P}<0,0001)$ e interação altura do dossel $\mathrm{x}$ época do ano $(\mathrm{P}<0,0001)$. Os valores de TSF foram crescentes com o aumento em altura do dossel (Tabela 32). Em relação às épocas do ano, houve um incremento nas TSF conforme as estações do ano avançaram, sendo os maiores valores registrados durante o final da primavera.

Tabela 32. Taxa de senescência de folhas (cm.perfilho ${ }^{-1} \cdot$ dia $^{-1}$ ) em pastos de capimMarandu mantidos em quatro alturas de dossel forrageiro por meio de lotação contínua em diferentes épocas do ano

\begin{tabular}{|c|c|c|c|c|c|c|c|c|c|c|c|}
\hline \multirow{2}{*}{$\begin{array}{c}\text { Época do } \\
\text { ano }\end{array}$} & \multicolumn{8}{|c|}{ Altura $(\mathrm{cm})$} & \multirow{2}{*}{ Média } & \multirow{2}{*}{\multicolumn{2}{|c|}{$\mathrm{EPM}^{*}$}} \\
\hline & \multicolumn{2}{|c|}{10} & \multicolumn{2}{|c|}{20} & \multicolumn{2}{|c|}{30} & \multicolumn{2}{|c|}{40} & & & \\
\hline Verão & 0,16 & $\mathrm{CA}$ & 0,28 & $\mathrm{bBC}$ & 0,36 & $\mathrm{~B}$ & 0,32 & $\mathrm{ab} D$ & 0,28 & ए & 0,01 \\
\hline Outono & 0,24 & b A & 0,26 & b BC & 0,41 & a B & 0,45 & a C & 0,34 & C & 0,02 \\
\hline Inverno & 0,20 & b A & 0,22 & b C & 0,40 & a B & 0,37 & $\mathrm{a} D$ & 0,30 & D & 0,01 \\
\hline Ini. Prim. & 0,21 & b A & 0,35 & $\mathrm{~b}$ AB & 0,59 & a A & 0,62 & a B & 0,44 & B & 0,03 \\
\hline Fin. Prim. & 0,23 & $\mathrm{~d}$ A & 0,45 & c A & 0,65 & b A & 1,10 & a A & 0,61 & A & 0,03 \\
\hline Média $^{\dagger}$ & 0,20 & d & 0,30 & c & 0,44 & $\mathrm{~b}$ & 0,50 & $\mathrm{a}$ & & & \\
\hline $\mathrm{EPM}^{*}$ & & 20 & 0,0 & & 0,0 & & & & & & \\
\hline
\end{tabular}

"Erro padrão da média

Erro padrão da média da interação: Verão=0,02, Outono=0,04, Inverno=0,02, Ini. Prim.=0,06 e Fin. Prim. $=0,06$.

Médias seguidas da mesma letra minúscula na linha e maiúscula na coluna não diferem entre si $(\mathrm{P}>0,10)$

$\dagger$ As médias das alturas correspondem à média de todos os meses do experimento

Com relação à taxa de remoção de folhas, houve efeito de altura do dossel $(\mathrm{P}=0,0286)$, época do ano $(\mathrm{P}<0,0001)$ e interação altura do dossel $\mathrm{x}$ época do ano $(\mathrm{P}=0,0041)$. As maiores reduções em comprimento foliar foram registradas em pastos mantidos a 10, 20 e $30 \mathrm{~cm}\left(1,04,0,97\right.$ e $1,13 \mathrm{~cm}$ folha $^{-1} \cdot$ dia $^{-1}$, respectivamente). Em relação às épocas do ano, os maiores valores foram encontrados durante o período de 
verão $\left(1,71 \mathrm{~cm} \cdot\right.$ perfilho $\left.{ }^{-1} \cdot \mathrm{dia}^{-1}\right)$, contrastando com o início de primavera, época em que foram observadas reduções de $0,18 \mathrm{~cm} \cdot$ perfilho $^{-1} \cdot$ dia $^{-1}$ (Tabela 33 ).

Tabela 33. Taxa de remoção de folhas (cm.perfilho ${ }^{-1} \cdot$ dia $^{-1}$ ) em pastos de capimMarandu mantidos em quatro alturas de dossel forrageiro por meio de lotação contínua em diferentes épocas do ano

\begin{tabular}{|c|c|c|c|c|c|c|c|c|c|c|c|}
\hline \multirow{2}{*}{$\begin{array}{c}\text { Época do } \\
\text { ano }\end{array}$} & \multicolumn{8}{|c|}{ Altura $(\mathrm{cm})$} & \multirow{2}{*}{\multicolumn{2}{|c|}{ Média }} & \multirow{2}{*}{ EPM* } \\
\hline & \multicolumn{2}{|c|}{10} & \multicolumn{2}{|c|}{20} & \multicolumn{2}{|c|}{30} & \multicolumn{2}{|c|}{40} & & & \\
\hline Verão & 1,48 & $\mathrm{bA}$ & 1,65 & $\mathrm{ab} \mathrm{A}$ & 1,93 & $\mathrm{aA}$ & 1,78 & ab $\mathrm{A}$ & 1,71 & $\mathrm{~A}$ & 0,07 \\
\hline Outono & 0,55 & a B & 0,49 & a B & 0,52 & a B & 0,15 & b D & 0,43 & C & 0,07 \\
\hline Inverno & 0,62 & a B & 0,25 & a B & 0,37 & a B & 0,49 & $\mathrm{aC}$ & 0,43 & $\mathrm{C}$ & 0,09 \\
\hline Ini. Prim. & 0,46 & a B & 0,20 & b B & 0,02 & $\mathrm{bC}$ & 0,04 & b D & 0,18 & D & 0,05 \\
\hline Fin. Prim. & 1,74 & a A & 1,38 & $\mathrm{bA}$ & 1,85 & a A & 0,90 & $\mathrm{c} \mathrm{B}$ & 1,47 & B & 0,06 \\
\hline Média $^{\dagger}$ & 1,04 & $\mathrm{ab}$ & 0,97 & $\mathrm{ab}$ & 1,13 & a & 0,88 & $\mathrm{~b}$ & & & \\
\hline $\mathrm{EPM}^{*}$ & & 06 & 0 , & & 0,0 & & & & & & \\
\hline
\end{tabular}

Erro padrão da média

Erro padrão da média da interação: Verão=0,14, Outono=0,14, Inverno=0,18, Ini. Prim.=0,10 e Fin. Prim. $=0,12$.

Médias seguidas da mesma letra minúscula na linha e maiúscula na coluna não diferem entre si $(\mathrm{P}>0,10)$

${ }^{\dagger}$ As médias das alturas correspondem à média de todos os meses do experimento

\subsubsection{Taxas de crescimento, senescência, remoção e acúmulo líquido de forragem do dossel}

Para as taxas de crescimento de folhas ( $\mathrm{kg}$ de MS.ha ${ }^{-1}$ ), houve efeito de altura do dossel $(\mathrm{P}=0,0152)$, época do ano $(\mathrm{P}<0,0001)$ e interação altura do dossel $\mathrm{x}$ época do ano $(\mathrm{P}<0,0019)$. A maior taxa foi registrada nos pastos mantidos a $30 \mathrm{~cm}(63,8 \mathrm{~kg}$ de MS. $\left.\mathrm{ha}^{-1} \cdot \mathrm{dia}^{-1}\right)$ e as menores nos pastos mantidos a 10, 20 e $40 \mathrm{~cm}\left(50,5 \mathrm{~kg}\right.$ de MS.ha ${ }^{-1} \cdot \mathrm{dia}^{-1}$, em média) (Tabela 34). Em relação as épocas do ano, as maiores taxas de crescimento de folhas foram registradas no período de verão $\left(89,9 \mathrm{~kg}\right.$ de $\left.\mathrm{MS}_{\mathrm{h}} \mathrm{ha}^{-1} \cdot \mathrm{dia}^{-1}\right)$ e as menores 
no início da primavera $\left(10,3 \mathrm{~kg}\right.$ de $\left.\mathrm{MS} \cdot \mathrm{ha}^{-1} \cdot \mathrm{dia}^{-1}\right)$. Durante as épocas de verão e final de primavera as taxas foram crescentes com a elevação da altura dos pastos até $30 \mathrm{~cm}$, quando se estabilizaram. Nas demais épocas do ano o padrão foi praticamente o inverso, ou seja, taxas decrescentes com o aumento da altura do dossel.

Tabela 34. Taxa de crescimento de folhas ( $\mathrm{kg}$ de $\left.\mathrm{MS}_{\mathrm{h}} \mathrm{ha}^{-1} \cdot \mathrm{dia}^{-1}\right)$ em pastos de capimMarandu mantidos em quatro alturas de dossel forrageiro por meio de lotação contínua em diferentes épocas do ano

\begin{tabular}{|c|c|c|c|c|c|c|c|c|c|c|c|}
\hline \multirow{2}{*}{$\begin{array}{c}\text { Época do } \\
\text { ano }\end{array}$} & \multicolumn{8}{|c|}{ Altura (cm) } & \multirow{2}{*}{ Média } & & \multirow{2}{*}{$\mathrm{EPM}^{*}$} \\
\hline & \multicolumn{2}{|c|}{10} & \multicolumn{2}{|c|}{20} & \multicolumn{2}{|c|}{30} & \multicolumn{2}{|c|}{40} & & & \\
\hline Verão & 72,9 & $\mathrm{bA}$ & 91,0 & $\mathrm{ab} \mathrm{A}$ & 106,6 & $\mathrm{aA}$ & 89,1 & $\mathrm{ab} A$ & 89,9 & A & 3,90 \\
\hline Outono & 39,8 & a B & 33,7 & $a b$ B & 39,9 & a C & 25,8 & b B & 34,8 & C & 2,59 \\
\hline Inverno & 24,8 & a C & 20,1 & ab C & 21,6 & ab D & 15,4 & b C & 20,5 & D & 1,36 \\
\hline Ini. Prim. & 11,5 & a D & 10,8 & a D & 11,0 & a E & 8,1 & b D & 10,3 & E & 0,46 \\
\hline Fin. Prim. & 43,8 & b B & 48,7 & b B & 77,6 & a B & 71,9 & a A & 60,5 & B & 3,87 \\
\hline Média $^{\dagger}$ & 47,3 & $\mathrm{~b}$ & 52,5 & $\mathrm{~b}$ & 63,8 & $\mathrm{a}$ & 51,9 & $\mathrm{~b}$ & & & \\
\hline EPM $^{*}$ & 2,7 & & 2,79 & & 2,79 & & 2,7 & & & & \\
\hline
\end{tabular}

Erro padrão da média

Erro padrão da média da interação: 7,80, Outono=5,18, Inverno=2,72, Ini. Prim. $=0,92$ e Fin. Prim.=7,74 Médias seguidas da mesma letra minúscula na linha e maiúscula na coluna não diferem entre si $(\mathrm{P}>0,10)$

${ }^{\dagger}$ As médias das alturas correspondem à média de todos os meses do experimento

Para a taxa de crescimento de hastes, houve efeito de altura do dossel $(\mathrm{P}=0,0043)$, época do ano $(\mathrm{P}<0,0001)$ e interação altura do dossel $\mathrm{x}$ época do ano $(\mathrm{P}=0,0021)$. Pastos mantidos a $30 \mathrm{e} 40 \mathrm{~cm}$ apresentaram os maiores valores $(14,3 \mathrm{~kg}$ de

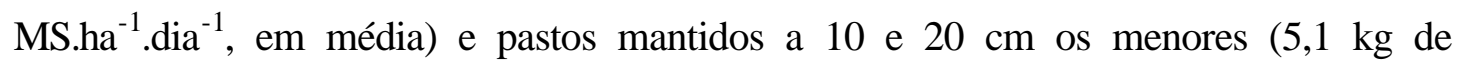

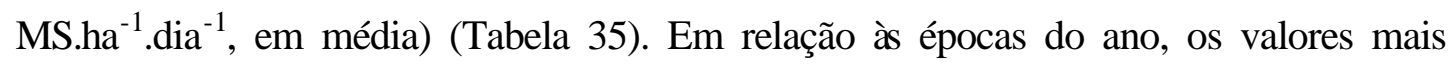
altos foram encontrados durante o período de verão e final de primavera $(18,1 \mathrm{~kg}$ de

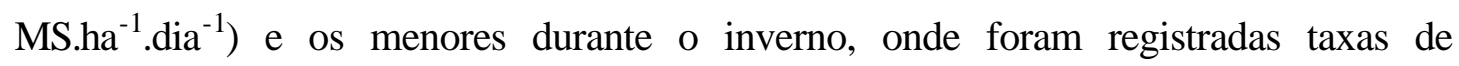
crescimento negativas $\left(-1,6 \mathrm{~kg}\right.$ de MS.ha $\left.{ }^{-1} \cdot \mathrm{dia}^{-1}\right)$. 
Tabela 35. Taxa de crescimento de hastes (kg de MS.ha ${ }^{-1} \cdot$ dia $\left.^{-1}\right)$ em pastos de capimMarandu mantidos em quatro alturas de dossel forrageiro por meio de lotação contínua em diferentes épocas do ano

\begin{tabular}{|c|c|c|c|c|c|c|c|c|c|c|c|}
\hline \multirow{2}{*}{$\begin{array}{c}\text { Época do } \\
\text { ano }\end{array}$} & \multicolumn{8}{|c|}{ Altura $(\mathrm{cm})$} & \multirow{2}{*}{\multicolumn{2}{|c|}{ Média }} & \multirow{2}{*}{ EPM* } \\
\hline & \multicolumn{2}{|c|}{10} & \multicolumn{2}{|c|}{20} & \multicolumn{2}{|l|}{30} & \multicolumn{2}{|c|}{40} & & & \\
\hline Verão & 7,5 & $\mathrm{DABC}$ & 14,9 & $\mathrm{bA}$ & 19,8 & $a b A$ & 28,3 & $a A$ & 17,6 & A & 2,41 \\
\hline Outono & $-3,4$ & c C & 1,9 & bc BC & 8,2 & ab B & 9,6 & a B & 4,1 & B & 1,32 \\
\hline Inverno & 1,2 & a B & $-2,6$ & bc C & $-3,3$ & $\mathrm{c} \mathrm{D}$ & $-1,5$ & b C & $-1,6$ & D & 0,27 \\
\hline Ini. Prim. & $-0,3$ & a C & $-0,6$ & ab B & $-1,2$ & b C & $-0,6$ & ab C & $-0,7$ & $\mathrm{C}$ & 0,15 \\
\hline Fin. Prim. & 10,9 & bc A & 9,3 & c A & 21,9 & ab A & 31,8 & a A & 18,5 & A & 2,43 \\
\hline Média $^{\dagger}$ & 3,4 & c & 6,8 & & 11,6 & & 16,9 & $\mathrm{a}$ & & & \\
\hline $\mathrm{EPM}^{*}$ & & 09 & 2, & & 2,09 & & 2,0 & & & & \\
\hline
\end{tabular}

Erro padrão da média

Erro padrão da média da interação: Verão=4,82, Outono=2,64, Inverno=0,54, Ini. Prim.=0,30 e Fin. Prim. $=4,96$.

Médias seguidas da mesma letra minúscula na linha e maiúscula na coluna não diferem entre si $(\mathrm{P}>0,10)$

${ }^{\dagger}$ As médias das alturas correspondem à média de todos os meses do experimento

Para a taxa de crescimento total (folhas + hastes), houve efeito de altura do dossel ( $\mathrm{P}=0,0152)$, época do ano $(\mathrm{P}<0,0001)$ e interação altura do dossel x época do ano $(\mathrm{P}=0,0019)$. Os resultados seguiram um padrão de resposta semelhante àquele observado para as taxas de crescimento de folhas e hastes, sendo que os maiores valores foram encontrados em dosséis mantidos a 30 e $40 \mathrm{~cm}\left(72,1 \mathrm{~kg}\right.$ de MS.ha $\left.{ }^{-1} \cdot \mathrm{dia}^{-1}\right)$. Já os pastos mantidos a 10 e $20 \mathrm{~cm}$ apresentaram os menores valores (55,0 kg de MS.ha $\left.{ }^{-1} \cdot \mathrm{dia}^{-1}\right)$ (Tabela 36). Em relação às épocas do ano, os valores mais altos foram registrados durante o período de verão $\left(107,6 \mathrm{~kg}\right.$ de $\left.\mathrm{MS}_{\mathrm{h}} \mathrm{ha}^{-1} \cdot \mathrm{dia}^{-1}\right)$, época a partir da qual as taxas foram diminuindo até atingirem os menores valores no início da primavera $(9,7 \mathrm{~kg}$ de MS.ha ${ }^{-1} \cdot \operatorname{dia}^{-1}$ ) 
Tabela 36. Taxa de crescimento total $\left(\mathrm{kg}\right.$ de MS.ha $\left.{ }^{-1} \cdot \mathrm{dia}^{-1}\right)$ em pastos de capim-Marandu mantidos em quatro alturas de dossel forrageiro por meio de lotação contínua em diferentes épocas do ano

\begin{tabular}{cccccccccccc}
\hline $\begin{array}{c}\text { Época do } \\
\text { ano }\end{array}$ & \multicolumn{9}{c}{10} & \multicolumn{9}{c}{ Altura (cm) } & \multicolumn{2}{c}{30} & & & \multirow{2}{*}{40} & & Média & \multirow{2}{*}{ EPM $^{*}$} \\
\hline Verão & 80,4 & b A & 105,9 & a A & 126,4 & a A & 117,5 & a A & 107,6 & A & 5,30 \\
Outono & 36,4 & a BC & 35,6 & a C & 48,1 & a C & 36,4 & a B & 39,1 & C & 3,13 \\
Inverno & 26,0 & a C & 17,6 & b D & 18,2 & b D & 13,9 & b C & 18,9 & D & 1,23 \\
Ini. Prim. & 11,2 & a D & 10,1 & a E & 9,8 & a E & 7,6 & b D & 9,7 & E & 0,42 \\
Fin. Prim. & 54,7 & b AB & 58,0 & b B & 99,5 & a B & 103,8 & a A & 79,0 & B & 5,74 \\
Média $^{\dagger}$ & 50,7 & c & 59,3 & bc & 75,4 & a & 68,8 & ab & & & \\
EPM $^{*}$ & 3,54 & & 3,54 & & 3,54 & & 3,54 & & & & \\
\hline
\end{tabular}

Erro padrão da média

Erro padrão da média da interação: Verão=10,60, Outono=6,26, Inverno=2,26, Ini. Prim.=0,84 e Fin. Prim.=11,48.

Médias seguidas da mesma letra minúscula na linha e maiúscula na coluna não diferem entre si $(\mathrm{P}>0,10)$

$\dagger$ As médias das alturas correspondem à média de todos os meses do experimento

A contribuição do alongamento de hastes para o crescimento total foi mais elevada nos pastos mantidos a $40 \mathrm{~cm}$, chegando a atingir $30 \%$ no final da primavera (Figura 35). Por outro lado, as hastes de pastos mantidos a $10 \mathrm{~cm}$ contribuíram menos para o crescimento total, atingindo um máximo de $20 \%$ durante o final da primavera. Durante o inverno e início da primavera a contribuição das hastes foi negativa.

Para a taxa de senescência, foi detectado efeito de altura do dossel $(\mathrm{P}<0,0001)$, época do ano $(\mathrm{P}<0,0001)$ e interação altura do dossel $\mathrm{x}$ época do ano $(\mathrm{P}<0,0001)$. As maiores taxas foram registradas nos pastos mantidos a 30 e $40 \mathrm{~cm}(25 \mathrm{~kg}$ de MS.ha $\left.{ }^{-1} \cdot \mathrm{dia}^{-1}\right)$ e as menores para aqueles mantidos a $10 \mathrm{~cm}\left(13,0 \mathrm{~kg}\right.$ de MS.ha $\left.{ }^{-1} \cdot \mathrm{dia}^{-1}\right)$ (Tabela 37). Em relação às épocas do ano, os maiores valores foram registrados durante o final da primavera $\left(31,3 \mathrm{~kg}\right.$ de MS.ha- $\left.{ }_{-}^{-1} \cdot \mathrm{dia}^{-1}\right)$ e os menores durante o inverno (13,9 $\mathrm{kg}$ de MS.ha ${ }^{-1} \cdot \mathrm{dia}^{-1}$ ). Os pastos mantidos a $40 \mathrm{~cm}$ apresentaram taxas de senescência superiores àqueles mantidos a $30 \mathrm{~cm}$ apenas no final primavera. 


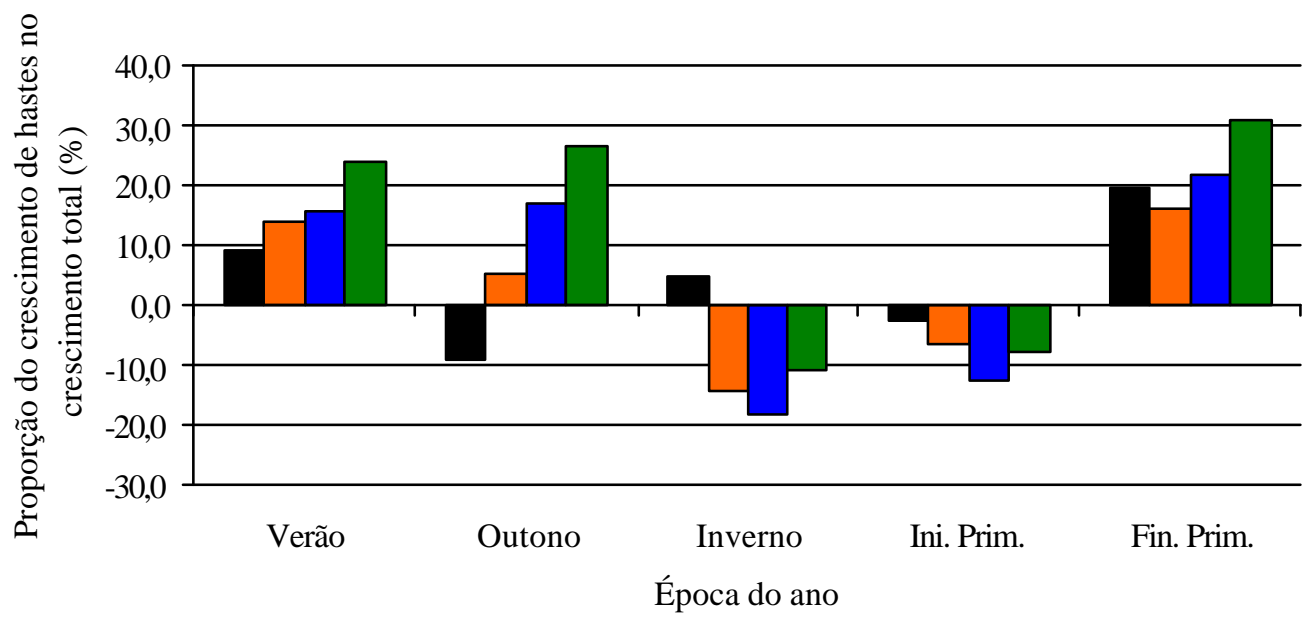

$10 \mathrm{~cm} \square 20 \mathrm{~cm} \square 30 \mathrm{~cm} \square 40 \mathrm{~cm}$

Figura 35 - Participação relativa do componente haste no crescimento total de pastos de capim-Marandu mantidos sob lotação contínua de Janeiro a Dezembro de 2002

Tabela 37. Taxa de senescência ( $\mathrm{kg}$ de $\mathrm{MS}_{\mathrm{n}} \mathrm{ha}^{-1} \cdot \mathrm{dia}^{-1}$ ) em pastos de capim-Marandu mantidos em quatro alturas de dossel forrageiro por meio de lotação contínua em diferentes épocas do ano

\begin{tabular}{cccccccccccc}
\hline $\begin{array}{c}\text { Epoca do } \\
\text { ano }\end{array}$ & \multicolumn{9}{c}{10} & \multicolumn{9}{c}{ Altura (cm) } & \multicolumn{2}{c}{30} & & \multicolumn{2}{c}{40} & & Média & \multirow{2}{*}{ EPM $^{*}$} \\
\hline Verão & 12,4 & c A & 20,5 & b AB & 25,7 & a B & 20,0 & b B & 19,6 & B & 1,08 \\
Outono & 15,6 & b A & 18,1 & b B & 26,5 & a B & 23,3 & a B & 20,9 & B & 1,08 \\
Inverno & 11,2 & b A & 12,6 & b C & 18,1 & a C & 13,6 & ab C & 13,9 & C & 1,08 \\
Ini. Prim. & 11,2 & c A & 18,6 & b B & 27,0 & a B & 20,9 & b B & 19,4 & B & 1,08 \\
Fin. Prim. & 13,0 & d A & 25,1 & c A & 36,9 & b A & 50,2 & a A & 31,3 & A & 1,08 \\
Média & 13,0 & c & 19,2 & b & 26,4 & a & 24,3 & a & & & \\
EPM $^{*}$ & 1,23 & 1,23 & 1,23 & & 1,23 & & & & \\
\hline
\end{tabular}

Erro padrão da média

Erro padrão da média da interação=2,16.

Médias seguidas da mesma letra minúscula na linha e maiúscula na coluna não diferem entre si $(\mathrm{P}>0,10)$

${ }^{\dagger}$ As médias das alturas correspondem à média de todos os meses do experimento 
A análise dos dados de acúmulo líquido (crescimento - senescência) indicou efeito de época do ano $(\mathrm{P}<0,0001)$ e interação altura do dossel $\mathrm{x}$ época do ano $(\mathrm{P}=0,0234)$. As maiores taxas foram registradas nos pastos mantidos a 20, 30 e $40 \mathrm{~cm}$ (44,5 kg de MS.ha- ${ }^{-1} \cdot$ dia $^{-1}$ ) (Tabela 38). Em relação às épocas do ano, as maiores taxas de acúmulo líquido foram registradas no período de verão $\left(87,9 \mathrm{~kg} \mathrm{de} \mathrm{MS}_{\mathrm{h}} \mathrm{ha}^{-1} \cdot \mathrm{dia}^{-1}\right)$ e as menores no início de primavera $\left(-9,7 \mathrm{~kg}\right.$ de MS.ha $\left.{ }^{-1} \cdot \mathrm{dia}^{-1}\right)$. Durante o verão e final da primavera, pastos mantidos a 30 e $40 \mathrm{~cm}$ apresentaram os maiores valores de taxa de acúmulo líquido. Comportamento oposto foi registrado durante o inverno e início da primavera, épocas em que os maiores valores foram mensurados nos pastos mantidos a $10 \mathrm{~cm}$ (Tabela 38).

Tabela 38. Taxa de acúmulo líquido (kg de MS.ha ${ }^{-1} \cdot \operatorname{dia}^{-1}$ ) em pastos de capim-Marandu mantidos em quatro alturas de dossel forrageiro por meio de lotação contínua em diferentes épocas do ano

\begin{tabular}{|c|c|c|c|c|c|c|c|c|c|c|c|}
\hline \multirow{2}{*}{$\begin{array}{c}\text { Epoca do } \\
\text { ano }\end{array}$} & \multicolumn{8}{|c|}{ Altura $(\mathrm{cm})$} & \multirow{2}{*}{ Média } & & \multirow{2}{*}{$\mathrm{EPM}^{*}$} \\
\hline & & 0 & & & 30 & & 4 & & & & \\
\hline Verão & 68,0 & $\mathrm{bA}$ & 85,5 & $\mathrm{ab} \mathrm{A}$ & 100,7 & $\mathrm{dA}$ & 97,5 & $\mathrm{a} A$ & 87,9 & A & 5,10 \\
\hline Outono & 20,7 & a C & 17,6 & a B & 21,6 & $\mathrm{aC}$ & 12,1 & a $C$ & 18,0 & $\mathrm{C}$ & 3,19 \\
\hline Inverno & 14,7 & $\mathrm{a} C$ & 5,0 & b C & 0,1 & c D & 0,2 & c D & 5,0 & $\mathrm{D}$ & 0,83 \\
\hline Ini. Prim. & 0,0 & $\mathrm{aD}$ & $-8,5$ & b D & $-17,2$ & $\mathrm{cE}$ & $-13,3$ & $b c E$ & $-9,7$ & $\mathrm{E}$ & 1,19 \\
\hline Fin. Prim. & 41,7 & ab B & 32,9 & b B & 62,6 & a B & 53,6 & ab B & 47,7 & B & 5,84 \\
\hline Média $^{\dagger}$ & 37,7 & $\mathrm{~b}$ & 40,1 & $a b$ & 48,8 & $\mathrm{a}$ & 44,5 & $a b$ & & & \\
\hline $\mathrm{EPM}^{*}$ & 4,18 & & 4,18 & & 4,18 & & 4,18 & & & & \\
\hline
\end{tabular}

Erro padrão da média

Erro padrão da média da interação: Verão=10,20, Outono=6,38, Inverno=1,66, Ini. Prim.=2,38 e Fin. Prim.=11,68.

Médias seguidas da mesma letra minúscula na linha e maiúscula na coluna não diferem entre si $(\mathrm{P}>0,10)$

${ }^{\dagger}$ As médias das alturas correspondem à média de todos os meses do experimento

Os dados de crescimento total, senescência e acúmulo líquido foram plotados em gráficos para uma melhor visualização dos resultados. Durante o verão as taxas de 
crescimento e senescência foram crescentes até a altura de $30 \mathrm{~cm}$, apresentando uma leve queda na altura de $40 \mathrm{~cm}$, o que resultou em comportamento praticamente idêntico para a taxa de acúmulo líquido (Figura 36).

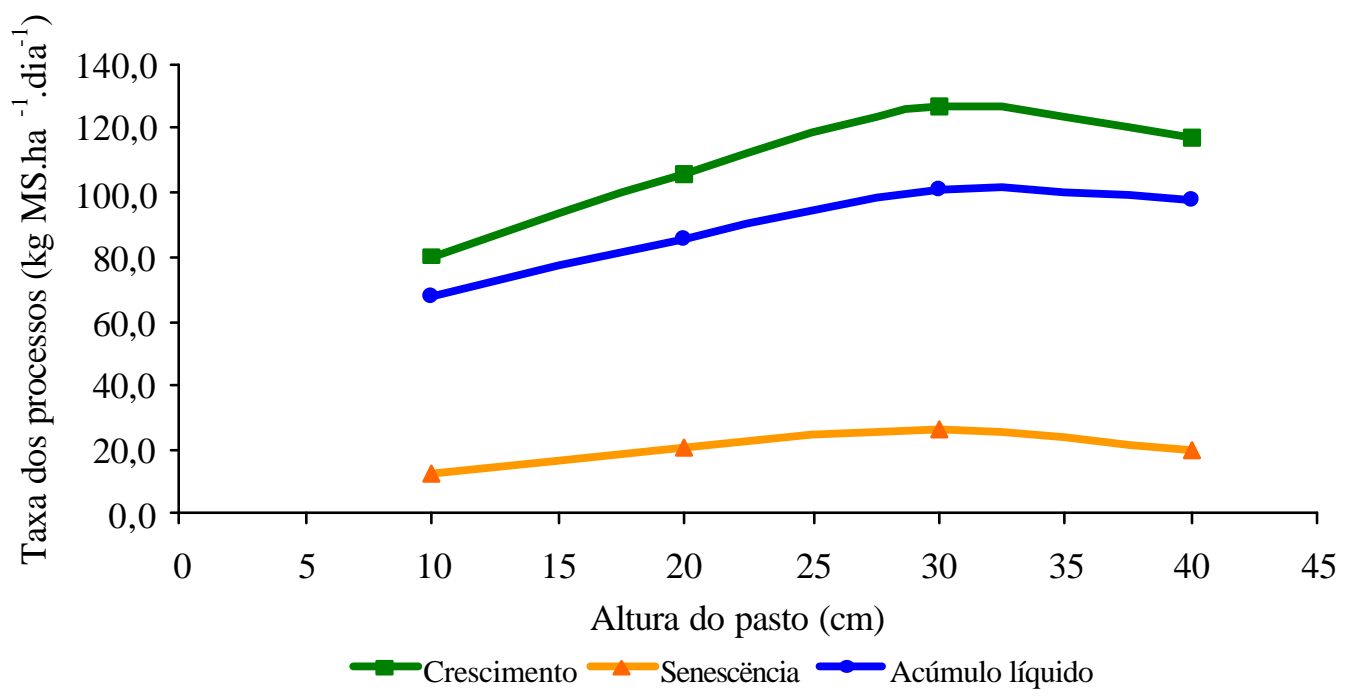

Figura 36 - Representação gráfica das taxas de crescimento, senescência e acúmulo líquido em pastos de capim-Marandu sob alturas de dossel forrageiro durante o período de verão

Durante o período de outono, os pastos apresentaram taxas de crescimento semelhantes, enquanto a senescência aumentou até a altura de $30 \mathrm{~cm}$. Nessa época do ano as taxas de acúmulo líquido foram menores que as de senescência a partir da altura de $20 \mathrm{~cm}$ (Figura 37). No inverno as taxas de crescimento diminuíram com o aumento em altura do dossel, enquanto que as taxas de senescência foram crescentes até a altura de $30 \mathrm{~cm}$. Pastos mantidos a 10 e $20 \mathrm{~cm}$ registraram um acúmulo líquido de forragem pequeno, enquanto que naqueles mantidos a 30 e $40 \mathrm{~cm}$ a taxa foi zero (Figura 38). No início da primavera as taxas de crescimento foram praticamente constantes para todas as alturas de dossel estudadas, enquanto que as taxas de senescência foram crescentes e maiores que as taxas de crescimento, o que resultou em acúmulo líquido negativo em 
pastos mantidos em alturas superiores a $20 \mathrm{~cm}$. Nos pastos mantidos a $10 \mathrm{~cm}$ a taxa de acúmulo líquido foi nula (Figura 39). No período de final de primavera a taxa de crescimento aumentou até se estabilizar na altura de $30 \mathrm{~cm}$, enquanto que a taxa de senescência apresentou um incremento linear. A taxa de acúmulo líquido não diferiu entre os pastos de 10 e $20 \mathrm{~cm}$, atingindo seu pico por volta da altura de $30 \mathrm{~cm}$ (Figura $40)$.

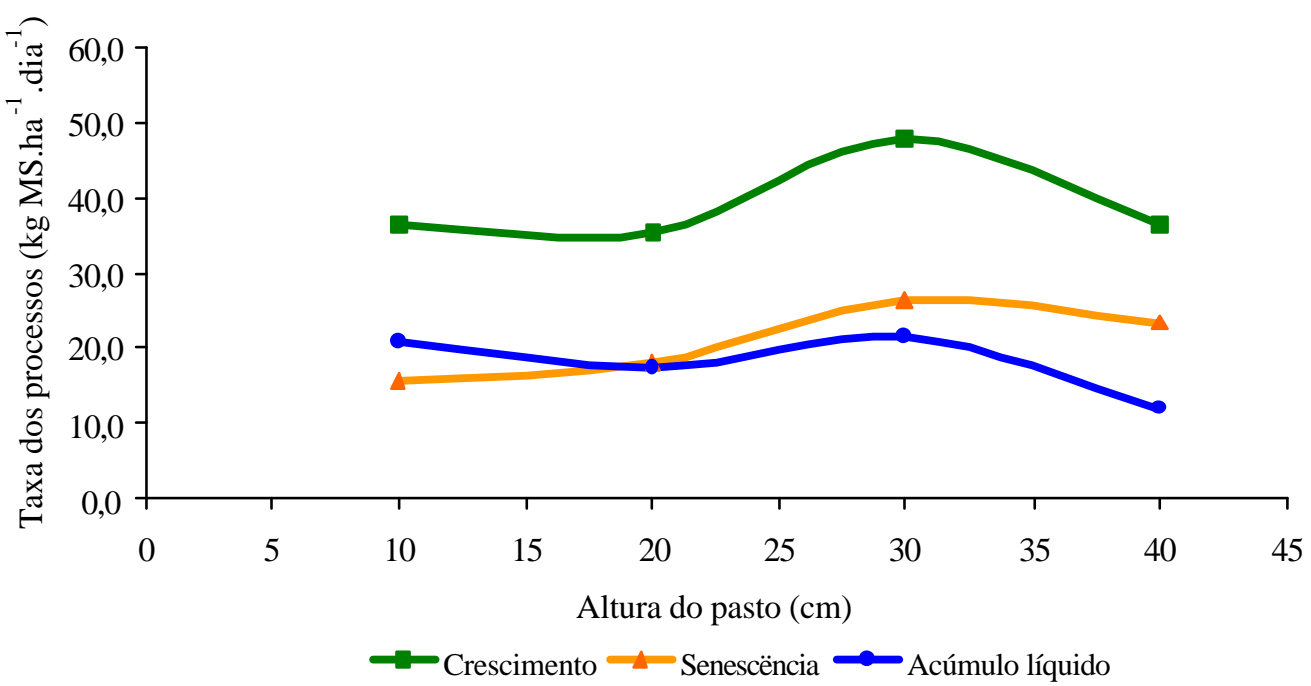

Figura 37 - Representação gráfica das taxas de crescimento, senescência e acúmulo líquido em pastos de capim-Marandu sob alturas de dossel forrageiro durante o período de outono 


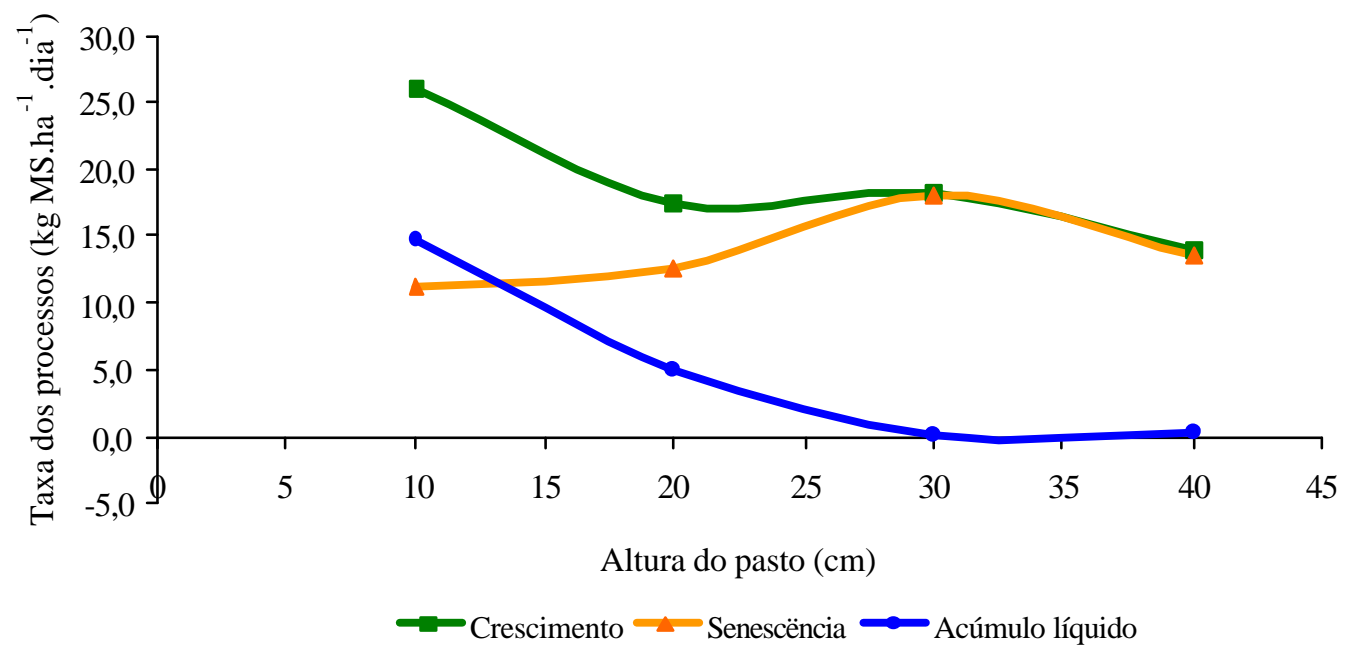

Figura 38 - Representação gráfica das taxas de crescimento, senescência e acúmulo líquido em pastos de capim-Marandu sob alturas de dossel forrageiro durante o período de inverno

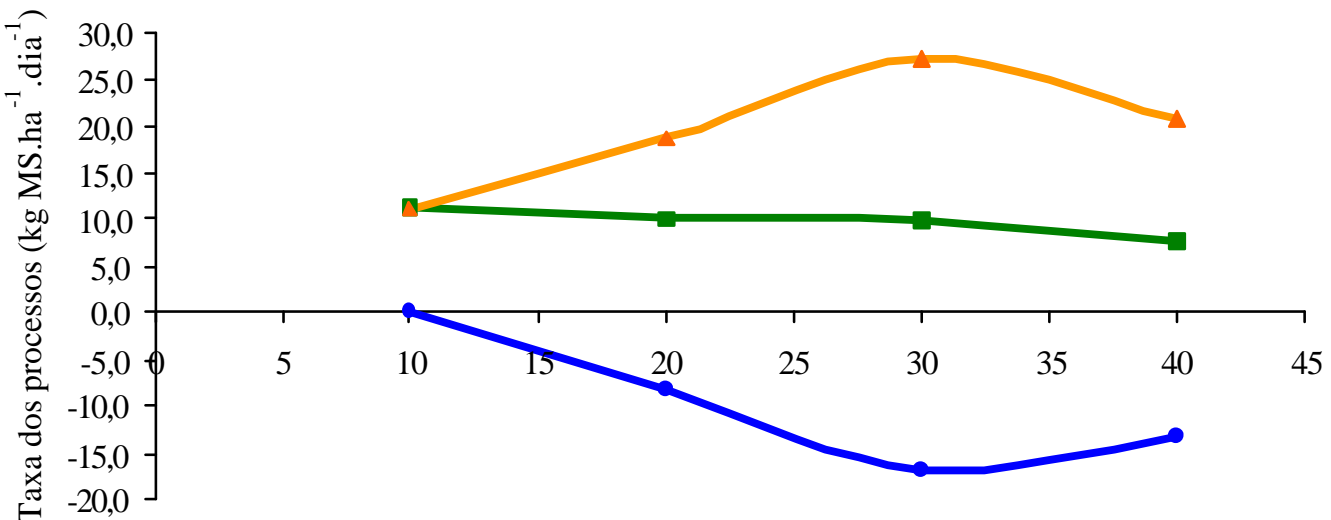

Altura do pasto (cm)

$\longrightarrow$ Crescimento $\longrightarrow$ Senescëncia $\rightarrow$ Acúmulo líquido

Figura 39 - Representação gráfica das taxas de crescimento, senescência e acúmulo líquido em pastos de capim-Marandu sob alturas de dossel forrageiro durante o período de início de primavera 


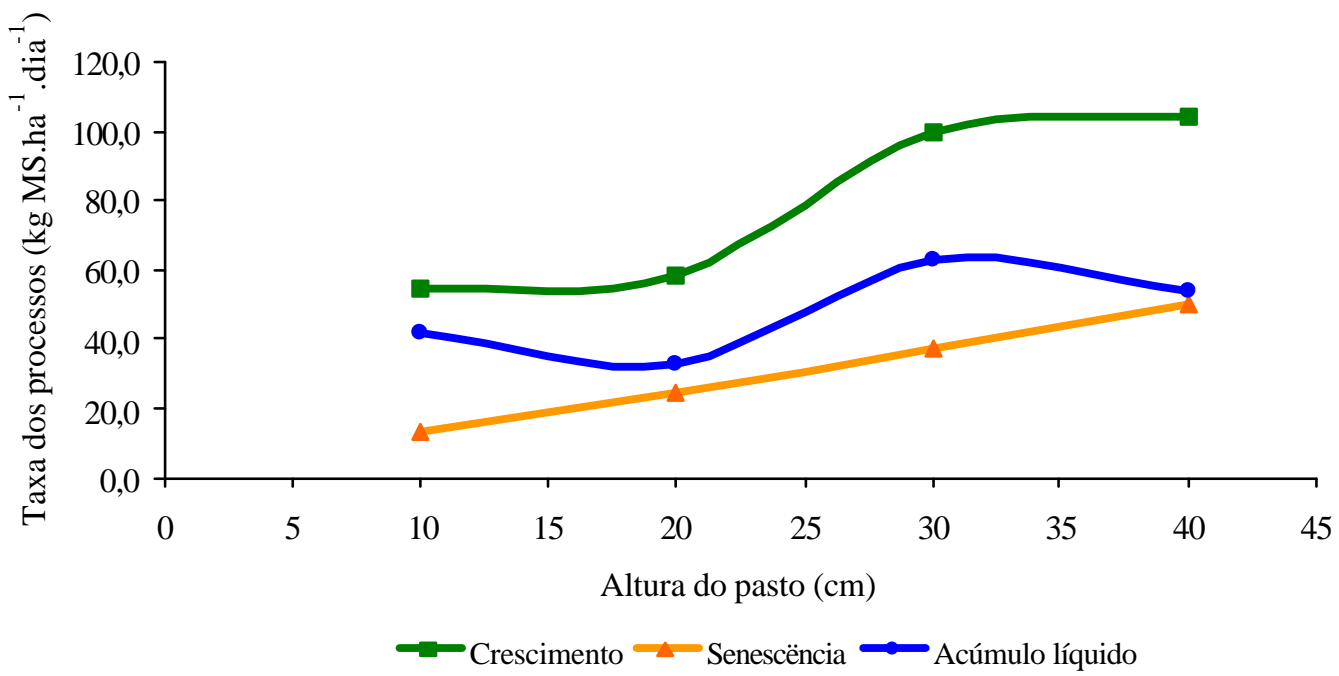

Figura 40 - Representação gráfica das taxas de crescimento, senescência e acúmulo líquido em pastos de capim-Marandu sob alturas de dossel forrageiro durante o período de final de primavera

Com relação à taxa de remoção de folhas, houve efeito de altura do dossel $(\mathrm{P}=0,0030)$, época do ano $(\mathrm{P}<0,0001)$ e interação altura do dossel $\mathrm{x}$ época do ano $(\mathrm{P}=0,0270)$. As maiores remoções ocorreram em pastos mantidos a 10, 20 e $30 \mathrm{~cm}(72,2$ $\mathrm{kg}$ de ${\mathrm{MS} . \mathrm{ha}^{-1}}^{-1} \cdot \mathrm{dia}^{-1}$, em média) e as menores naqueles mantidos a $40 \mathrm{~cm}$, que apresentaram taxas de remoção de 50,2 kg de MS.ha ${ }^{-1} \cdot d^{-1}{ }^{-1}$ (Tabela 39). Ao longo do ano as maiores taxas de remoção de folhas ocorreram no verão, decrescendo durante o outono, inverno e início da primavera e voltando a aumentar no final dessa estação. 
Tabela 39. Taxa de remoção de folhas ( $\mathrm{kg}$ de $\left.M \mathrm{MS} \cdot \mathrm{ha}^{-1} \cdot \operatorname{dia}^{-1}\right)$ em pastos de capimMarandu mantidos em quatro alturas de dossel forrageiro por meio de lotação contínua em diferentes épocas do ano

\begin{tabular}{cccccccccccc}
\hline $\begin{array}{c}\text { Epoca do } \\
\text { ano }\end{array}$ & \multicolumn{9}{c}{10} & \multicolumn{9}{c}{20} & \multicolumn{2}{c}{30} & \multicolumn{2}{c}{40} & & Média & \multirow{2}{*}{ EPM $^{*}$} \\
\hline Verão & 116,7 & b A & 122,8 & ab A & 140,4 & a A & 106,1 & b A & 121,5 & A & 4,83 \\
Outono & 37,9 & a B & 34,4 & a C & 33,1 & a C & 8,6 & b C & 28,5 & C & 4,37 \\
Inverno & 34,5 & a B & 14,9 & a CD & 16,6 & a CD & 20,4 & a C & 21,6 & C & 5,05 \\
Ini. Prim. & 26,7 & a B & 10,5 & b D & 1,1 & b D & 1,5 & b C & 9,9 & D & 3,03 \\
Fin. Prim. & 97,0 & a A & 77,6 & b B & 104,5 & a B & 44,0 & c B & 80,8 & B & 3,71 \\
Média $^{\dagger}$ & 73,0 & a & 67,5 & a & 76,2 & a & 50,2 & b & & & \\
EPM $^{*}$ & 3,69 & 3,69 & 3,69 & 3,69 & & & \\
\hline
\end{tabular}

Erro padrão da média

Erro padrão da média da interação: Verão=9,66, Outono=8,74, Inverno=10,1, Ini. Prim.=6,06 e Fin. Prim.=7,42.

Médias seguidas da mesma letra minúscula na linha e maiúscula na coluna não diferem entre si $(\mathrm{P}>0,10)$

$\dagger$ As médias das alturas correspondem à média de todos os meses do experimento

Já para as taxas de remoção de hastes houve efeito apenas de época do ano $(\mathrm{P}=0,005)$, com os maiores valores registrados durante o verão $\left(12,9 \mathrm{~kg}\right.$ de $\left.\mathrm{MS}_{\mathrm{h}} \mathrm{ha}^{-1} \cdot \mathrm{dia}^{-1}\right)$ e os menores durante o inverno e início de primavera $\left(0,35 \mathrm{~kg}\right.$ de $\mathrm{MS}_{\mathrm{h}} \mathrm{ha}^{-1} \cdot \mathrm{dia}^{-1}$, em média) (Tabela 40). A média geral das alturas foi de 5,3 $\mathrm{kg}$ de $\mathrm{MS}_{\mathrm{h}} \mathrm{ha}^{-1} \cdot \mathrm{dia}^{-1}$.

Em termos de remoção total de forragem (folhas + hastes) houve efeito de altura do dossel $(\mathrm{P}=0,015)$, época do ano $(\mathrm{P}<0,0001)$ e interação altura do dossel $\mathrm{x}$ época do ano $(\mathrm{P}=0,0554)$. As maiores taxas de remoção de forragem foram encontradas em dosséis mantidos a 10, 20 e $30 \mathrm{~cm}\left(77,7 \mathrm{~kg}\right.$ de $\left.\mathrm{MS}_{\mathrm{h}} \mathrm{ha}^{-1} \cdot \mathrm{dia}^{-1}\right)$ e as menores naqueles mantidos a $40 \mathrm{~cm}\left(55,0 \mathrm{~kg}\right.$ de MS.ha $\left.{ }^{-1} \cdot \mathrm{dia}^{-1}\right)$. As maiores taxas foram registradas durante o verão $\left(134,4 \mathrm{~kg}\right.$ de $\left.\mathrm{MS}_{\mathrm{h}} \mathrm{ha}^{-1} \cdot \mathrm{dia}^{-1}\right)$ e as menores no início de primavera (10,2 kg de MS.ha $\left.{ }^{-1} \cdot \operatorname{dia}^{-1}\right)$ (Tabela 41). 
Tabela 40. Taxa de remoção de hastes ( $\mathrm{kg}$ de $\left.M \mathrm{MS} \cdot \mathrm{ha}^{-1} \cdot \operatorname{dia}^{-1}\right)$ em pastos de capimMarandu mantidos em quatro alturas de dossel forrageiro por meio de lotação contínua em diferentes épocas do ano

\begin{tabular}{|c|c|c|c|c|c|c|c|}
\hline \multirow{2}{*}{$\begin{array}{c}\text { Época do } \\
\text { ano }\end{array}$} & \multicolumn{4}{|c|}{ Altura $(\mathrm{cm})$} & \multirow{2}{*}{\multicolumn{2}{|c|}{ Média }} & \multirow{2}{*}{$\mathrm{EPM}^{*}$} \\
\hline & 10 & 20 & 30 & 40 & & & \\
\hline Verão & 14,3 & 11,1 & 14,3 & 11,9 & 12,9 & A & 1,79 \\
\hline Outono & 1,1 & 1,2 & 0,7 & 1,4 & 1,1 & B & 0,35 \\
\hline Inverno & 1,0 & 0,2 & 0,3 & 0,4 & 0,5 & $\mathrm{CD}$ & 0,21 \\
\hline Ini. Prim. & 1,0 & 0,0 & 0,0 & 0,0 & 0,2 & D & 0,16 \\
\hline Fin. Prim. & 3,2 & 0,6 & 0,7 & 0,0 & 1,1 & $\mathrm{BC}$ & 0,39 \\
\hline Média $^{\dagger}$ & 6,3 & 4,5 & 5,6 & 4,9 & & & \\
\hline $\mathrm{EPM}^{*}$ & 1,23 & 1,23 & 1,23 & 1,23 & & & \\
\hline
\end{tabular}

Erro padrão da média

Médias seguidas da mesma letra minúscula na linha e maiúscula na coluna não diferem entre si $(\mathrm{P}>0,10)$

${ }^{\dagger}$ As médias das alturas correspondem à média de todos os meses do experimento

Tabela 41. Taxa de remoção total de forragem $\left(\mathrm{kg} \mathrm{de} \mathrm{MS.ha-}{ }^{-1} \cdot \operatorname{dia}^{-1}\right)$ em pastos de capimMarandu mantidos em quatro alturas de dossel forrageiro por meio de lotação contínua em diferentes épocas do ano

\begin{tabular}{|c|c|c|c|c|c|c|c|c|c|c|c|}
\hline \multirow{2}{*}{$\begin{array}{c}\text { Época do } \\
\text { ano }\end{array}$} & \multicolumn{8}{|c|}{ Altura $(\mathrm{cm})$} & \multirow{2}{*}{\multicolumn{2}{|c|}{ Média }} & \multirow{2}{*}{$\mathrm{EPM}^{*}$} \\
\hline & 10 & & 20 & & 30 & & 40 & & & & \\
\hline Verão & 131,0 & $\mathrm{ab} A$ & 133,8 & $\mathrm{ab} A$ & 154,7 & $\mathrm{a} A$ & 118,0 & $\mathrm{bA}$ & 134,4 & & 6,54 \\
\hline Outono & 39,0 & a B & 35,6 & a C & 33,7 & a C & 10,0 & $\mathrm{~b} C \mathrm{CD}$ & 29,6 & $\mathrm{C}$ & 4,30 \\
\hline Inverno & 35,6 & a B & 15,2 & $\mathrm{~b} C \mathrm{CD}$ & 16,9 & $\mathrm{~b} \mathrm{C}$ & 20,7 & $\mathrm{ab} C$ & 22,1 & C & 3,55 \\
\hline Ini. Prim. & 27,7 & a B & 10,5 & b D & 1,1 & b D & 1,5 & b D & 10,2 & D & 2,56 \\
\hline Fin. Prim. & 100,3 & $\mathrm{ab} A$ & 78,2 & b B & 105,2 & a B & 44,0 & c B & 81,9 & B & 4,49 \\
\hline Média $^{\dagger}$ & 79,3 & a & 72,1 & a & 81,8 & a & 55,0 & $\mathrm{~b}$ & & & \\
\hline $\mathrm{EPM}^{*}$ & 3,48 & & 3,48 & & 3,48 & & 3,48 & & & & \\
\hline
\end{tabular}

"Erro padrão da média

Erro padrão da média da interação: Verão=13,08, Outono=8,60, Inverno=7,10, Ini. Prim.=5,12 e Fin. Prim=8,98.

Médias seguidas da mesma letra minúscula na linha e maiúscula na coluna não diferem entre si $(\mathrm{P}>0,10)$

${ }^{\dagger}$ As médias das alturas correspondem à média de todos os meses do experimento 


\subsection{Compensação tamanho/densidade populacional de perfilhos}

A relação funcional entre a densidade populacional de perfilhos e a massa média por perfilho foi estabelecida por meio de regressões lineares simples. Os resultados obtidos (parâmetros do modelo) encontram se nas Tabelas 42 e 43. As regressões não foram significativas durante os períodos de outono e final de primavera.

$\mathrm{Na}$ Tabela 42 o coeficiente $\mathrm{G}$ foi calculado assumindo-se densidade aparente constante $\left(950 \mathrm{~kg} \cdot \mathrm{m}^{-3}\right)$ no cálculo de volume para os perfilhos nas alturas de dossel estudadas. Considerando-se os desvios dos coeficientes angulares, os três parâmetros $\left(\mathrm{C}_{\mathrm{a}}, \mathrm{C}_{\mathrm{r}}\right.$ e $\left.\mathrm{C}_{\mathrm{d}}\right)$ explicaram as inclinações para a maioria das épocas estudadas, exceção feita ao início da primavera. Na Tabela 43 o cálculo de $\mathrm{C}_{\mathrm{r}}$ foi realizado a partir dos volumes efetivamente medidos com o "volumímetro". Nesse caso, os coeficientes explicaram as variações nos coeficientes angulares em todos os meses. 
Tabela 42. Parâmetros da regressão entre o Log da densidade populacional de perfilhos e o Log da massa média por perfilho. Inclinação predita estimada pressupondo uma densidade constante de $950 \mathrm{~kg} \cdot \mathrm{m}^{-3}$ no cálculo de $\mathrm{Cr}$

\begin{tabular}{|c|c|c|c|c|c|}
\hline Parâmetros* & Regressão & $\mathrm{C}_{\mathrm{a}}^{\dagger}$ & $\mathrm{C}_{\mathrm{r}}^{\dagger}$ & $\mathrm{C}_{\mathrm{d}}^{\dagger}$ & $\begin{array}{c}\text { Inclinação } \\
\text { predita }\end{array}$ \\
\hline \multicolumn{6}{|c|}{ Verão } \\
\hline$\hat{a}$ & $-3,92(0,53)$ & $3,67(0,99)$ & $-1,19(0,30)$ & & \multirow{4}{*}{3,98} \\
\hline$\hat{\mathrm{a}}_{0}$ & $14,75(1,61)$ & & & & \\
\hline $\mathrm{R}^{2}$ & 0,96 & 0,84 & 0,86 & & \\
\hline $\mathrm{P}$ & 0,0396 & 0,15 & 0,14 & & \\
\hline \multicolumn{6}{|c|}{ Outono } \\
\hline$\hat{a}$ & $-3,41(1,04)$ & $2,84(1,08)$ & $-0,91(0,27)$ & & \multirow{4}{*}{3,43} \\
\hline$\hat{\mathrm{a}}_{0}$ & $12,99(3,09)$ & & & & \\
\hline $\mathrm{R}^{2}$ & 0,79 & 0,65 & 0,81 & & \\
\hline $\mathrm{P}$ & 0,20 & 0,35 & 0,19 & & \\
\hline \multicolumn{6}{|c|}{ Inverno } \\
\hline$\hat{a}$ & $-2,05(0,40)$ & $1,12(0,30)$ & $-0,58(0,06)$ & $0,06(0,02)$ & \multirow{4}{*}{$-2,10$} \\
\hline$\hat{\mathrm{a}}_{0}$ & $8,77(1,15)$ & & & & \\
\hline $\mathrm{R}^{2}$ & 0,92 & 0,84 & 0,99 & 0,78 & \\
\hline $\mathrm{P}$ & 0,08 & 0,16 & 0,019 & 0,22 & \\
\hline \multicolumn{6}{|c|}{ Início da Primavera } \\
\hline$\hat{a}$ & $-1,70(0,34)$ & $0,76(0,34)$ & $-0,54(0,27)$ & $0,15(0,04)$ & \multirow{4}{*}{$-1,87$} \\
\hline$\hat{\mathrm{a}}_{0}$ & $7,85(0,98)$ & & & & \\
\hline $\mathrm{R}^{2}$ & 0,91 & 0,48 & 0,08 & 0,84 & \\
\hline $\mathrm{P}$ & 0,08 & 0,52 & 0,91 & 0,16 & \\
\hline \multicolumn{6}{|c|}{ Final da Primavera } \\
\hline$\hat{a}$ & $-2,88(0,74)$ & $3,18(0,96)$ & $-2,02(0,38)$ & $0,18(0,08)$ & \multirow{4}{*}{$-2,84$} \\
\hline$\hat{\mathrm{a}}_{0}$ & $11,27(2,16)$ & & & & \\
\hline $\mathrm{R}^{2}$ & 0,86 & 0,80 & 0,92 & 0,30 & \\
\hline $\mathrm{P}$ & 0,14 & 0,20 & 0,07 & 0,7 & \\
\hline $\begin{array}{l}\text { â }=\text { coeficient } \\
\text { regressão. } \\
C_{\mathrm{a}}, \mathrm{C}_{\mathrm{r}} \text { e } \mathrm{C}_{\mathrm{C}}, \mathrm{cc} \\
\text { Calculada se }\end{array}$ & ular, $\hat{a}_{0}=$ coe & e linear, $\mathrm{R}^{2}=$ & ficiente de d & $\begin{array}{l}\text { inação e } \mathrm{P}= \\
\text { pectivamente } \\
\left.{ }_{\mathrm{d}}+3 / 2\right) \text {. }\end{array}$ & \\
\hline
\end{tabular}


Tabela 43. Parâmetros da regressão entre o Log da densidade populacional de perfilhos e o Log da massa média por perfilho. Inclinação predita estimada pressupondo densidade variável no cálculo de $\mathrm{Cr}$

\begin{tabular}{|c|c|c|c|c|c|}
\hline Parâmetros* & Regressão & $\mathrm{C}_{\mathrm{a}}^{\dagger}$ & $\mathrm{C}_{\mathrm{r}}^{\dagger}$ & $\mathrm{C}_{\mathrm{d}}^{\dagger}$ & $\begin{array}{c}\text { Inclinação } \\
\text { predita }^{\ddagger}\end{array}$ \\
\hline \multicolumn{6}{|c|}{ Verão } \\
\hline$\hat{a}$ & $-3,92(0,53)$ & $3,67(0,99)$ & $-1,19(0,30)$ & \multirow{4}{*}{$\mathrm{NC}$} & \multirow{4}{*}{3,98} \\
\hline$\hat{\mathrm{a}}_{0}$ & $14,75(1,61)$ & & & & \\
\hline $\mathrm{R}^{2}$ & 0,96 & 0,84 & 0,86 & & \\
\hline $\mathrm{P}$ & 0,0396 & 0,15 & 0,14 & & \\
\hline \multicolumn{6}{|c|}{ Outono } \\
\hline$\hat{a}$ & $-3,41(1,04)$ & $2,84(1,08)$ & $-0,91(0,27)$ & \multirow{4}{*}{$\mathrm{NC}$} & \multirow{4}{*}{3,43} \\
\hline$\hat{a}_{0}$ & $12,99(3,09)$ & & & & \\
\hline $\mathrm{R}^{2}$ & 0,79 & 0,65 & 0,81 & & \\
\hline $\mathrm{P}$ & 0,20 & 0,35 & 0,19 & & \\
\hline \multicolumn{6}{|c|}{ Inverno } \\
\hline$\hat{a}$ & $-2,05(0,40)$ & $1,12(0,30)$ & $-0,65(0,14)$ & \multirow{4}{*}{$\mathrm{NC}$} & \multirow{4}{*}{$-1,97$} \\
\hline$\hat{\mathrm{a}}_{0}$ & $8,77(1,15)$ & & & & \\
\hline $\mathrm{R}^{2}$ & 0,92 & 0,84 & 0,99 & & \\
\hline $\mathrm{P}$ & 0,08 & 0,16 & 0,019 & & \\
\hline \multicolumn{6}{|c|}{ Início da Primavera } \\
\hline$\hat{a}$ & $-1,70(0,34)$ & $0,76(0,34)$ & $-0,52(0,24)$ & \multirow{5}{*}{$\mathrm{NC}$} & \multirow{4}{*}{$-1,74$} \\
\hline$\hat{\mathrm{a}}_{0}$ & $7,85(0,98)$ & & & & \\
\hline $\mathrm{R}^{2}$ & 0,91 & 0,48 & 0,08 & & \\
\hline $\mathrm{P}$ & 0,08 & 0,52 & 0,91 & & \\
\hline \multicolumn{5}{|c|}{ Final da Primavera } & \\
\hline$\hat{a}$ & $-2,88(0,74)$ & $3,18(0,96)$ & $-1,73(0,47)$ & \multirow{4}{*}{$\mathrm{NC}$} & \multirow{4}{*}{$-2,95$} \\
\hline$\hat{\mathrm{a}}_{0}$ & $11,27(2,16)$ & & & & \\
\hline $\mathrm{R}^{2}$ & 0,86 & 0,80 & 0,92 & & \\
\hline $\mathrm{P}$ & 0,14 & 0,20 & 0,07 & & \\
\hline
\end{tabular}

$\hat{\mathrm{a}}=$ coeficiente angular, $\hat{\mathrm{a}}_{0}=$ coeficiente linear, $\mathrm{R}^{2}=$ coeficiente de determinação e $\mathrm{P}=$ probabilidade da regressão.

${ }^{\top} \mathrm{C}_{\mathrm{a}}, \mathrm{C}_{\mathrm{r}}$ e $\mathrm{C}_{\mathrm{r}}$, correções para variações em IAF, $\mathrm{R}$ e densidade aparente, respectivamente.

${ }^{\ddagger}$ Calculada segundo Matthew et al. (1995), onde inclinação $=-\left(C_{a}+C_{F}+C_{d}+3 / 2\right)$.

Os valores entre parênteses correspondem ao desvio padrão dos coeficientes

$\mathrm{NC}=$ não calculado 


\section{DISCUSSÃO}

\subsection{Manutenção das condições experimentais}

As alturas de dossel pré-estabelecidas apresentaram-se relativamente constantes ao longo do período experimental (Figura 6). As variações ocorridas, principalmente em dosséis de 30 e $40 \mathrm{~cm}$, podem ser atribuídas às seguintes razões: (1) Entre os dias $14 \mathrm{e}$ 26 de janeiro, 24 a 26 de fevereiro, 29 de abril e 1 de maio, 23 e 25 de julho, 26 e 28 de agosto e 16 e 18 de dezembro de 2002 foram realizadas na área experimental avaliações de consumo e comportamento ingestivo de bovinos (Sarmento, 2003), sendo que em algumas datas os pastos foram rebaixados além do previsto em função da necessidade de manutenção dos animais nas unidades experimentais além do tempo previsto no protocolo de ajuste de taxa de lotação; (2) Dificuldades no ajuste da taxa de lotação, já que a adição de um animal (250 kg de peso vivo) poderia implicar em variações na lotação instantânea de até 4,6 UA ha ${ }^{-1}$; (3) Acúmulo líquido de forragem negativo (Tabela 38) no período de início de primavera, ou seja, reduções na altura do dossel foram o resultado natural de taxas baixas de crescimento quando comparadas às de senescência. Apesar disso, a manutenção das condições experimentais pode ser considerada extremamente satisfatória, uma vez que foi possível manter contrastes adequados entre alturas ao longo de todos os meses do ano. 


\subsection{Características morfogênicas}

O efeito da altura do dossel sobre o NFV (Tabela 7) refletiu basicamente o efeito da taxa de lotação sobre essa variável. Isso porque para manter os pastos mais baixos foi necessário um maior número de animais por unidade de área (Andrade, 2004), o que aumentou a freqüência de visitação de perfilhos individuais (Gonçalves, 2003) contribuindo para a redução dos valores de NFV em pastos de 10 e $20 \mathrm{~cm}$. Os valores encontrados neste experimento são semelhantes àqueles reportados por Peternelli (2003) para a mesma planta forrageira. Normalmente, o NFV é um valor relativamente constante para um mesmo genótipo (Lemaire \& Chapman, 1996; Matthew et al., 2000), porém práticas de manejo (especialmente aumentos em taxa de lotação) podem alterá-lo.

Em relação às épocas do ano, o déficit hídrico acentuado (Figura 4) verificado no mês de outubro (início de primavera) pode ser considerado o principal responsável pelos maiores valores de NFV observados durante o final da primavera. Isso porque a redução na taxa de aparecimento de folhas (Tabelas 8 e 9) no início da primavera resultou numa redução no número de folhas em expansão por perfilho (Tabela 5), contribuindo para que não houvesse uma reconstituição compatível no NFV. O aumento do número de folhas vivas e em expansão no final da primavera pode ter sido resultado do período de escassez hídrica verificada em setembro-outubro. Nelson (2000) comentou que em condições de estresse hídrico, quando a taxa de alongamento foliar é lenta (Tabela 31), o meristema pode continuar produzindo primórdios foliares. Assim, apesar do filocrono ter aumentado nesse mesmo período (Tabelas 10 e 11), pode não ter havido um aumento proporcional no plastocrono, ou seja, no intervalo entre o aparecimento de primórdios foliares no meristema. Dessa forma, quando as condições hídricas foram restabelecidas, ajudadas pela fertilização nitrogenada (Tabela 2), esses primórdios fliares passaram a se expandir rapidamente, elevando o NFE e, conseqüentemente, o NFV. Pinto (2000), trabalhando com cultivares do gênero Cynodon, e Mazzanti (1997), com Lolium multiflorum Lam. (azevém anual), também observaram variações sazonais no NFV. 
O número de folhas senescentes (Tabela 6) foi consistentemente menor que o número de folhas em expansão por perfilho (Tabela 6). Isso significa que para manter um NFV relativamente constante (Tabela 7) a duração do período de senescência deve ter sido muito menor que o de alongamento de folhas. Ao longo das estações o número de folhas senescentes foi aumentado, enquanto o NFE mostrou uma certa estabilidade, de forma que a relação NFE/NFS foi de 4,7, 2,5, 1,9, 1,3 e 1,6 durante o verão, outono, inverno, início e final da primavera, respectivamente. Os menores valores de NFS nos pastos mantidos a 10 e $20 \mathrm{~cm}$ podem ser atribuídos às maiores taxas de lotação (Andrade, 2004) e maior frequiência e intensidade de desfolhação (Gonçalves, 2003) de perfilhos sob aquelas condições, uma vez que muitas vezes folhas inteiras eram removidas não permitindo que elas o processo de senescência ocorresse simplesmente por não existirem mais.

A taxa de aparecimento de folhas (TAF) possui um papel determinante nas características estruturais do dossel uma vez que interfere diretamente no tamanho da folha, na densidade populacional de perfilhos e no número de folhas por perfilho (Lemaire \& Chapman, 1996). Seu inverso, o filocrono, também pode ser discutido nos mesmos termos. Houve grande variação em filocrono com as alturas de dossel estudadas e com as épocas do ano (Tabela 10). Em média, a TAF foi 50\% maior em pastos mantidos a $10 \mathrm{~cm}$ quando comparados com pastos mantidos a $40 \mathrm{~cm}$ (Tabela 8). Peternelli (2003) avaliou a TAF em capim-Marandu durante o período de verão e não observou diferença entre as intensidades de pastejo estudadas, apenas entre meses de avaliação, sendo que a média do período foi de 0,11 folha.perfilho ${ }^{-1} \cdot$ dia $^{-1}$, valores ligeiramente superiores aos obtidos no presente experimento para período equivalente (Tabela 8). Diversos autores mostraram que o aumento no comprimento da bainha foliar resulta em valores maiores de filocronos (Wilson \& Laidlaw, 1985; Skinner \& Nelson, 1995), uma vez que o tempo necessário para a visualização da nova folha emergida pode ser atrasado segundo uma relação basicamente estabelecida pelo comprimento das bainhas que envolvem o meristema apical e a taxa de alongamento foliar. Além disso, Gautier \& Varlet-Grancher (1996) mostraram que variações em IAF podem alterar a TAF por meio de mudanças na qualidade do ambiente luminoso. No entanto, não foram 
encontrados trabalhos relacionando a qualidade de luz e a dinâmica do aparecimento de folhas em espécies tropicais, de tal forma que seus efeitos necessitam ser melhor estudados. Apesar de não terem sido realizadas avaliações relativas à altura do meristema apical e comprimento da bainha foliar, os resultados de comprimento de folhas intactas e hastes, (Tabelas 15 e 16) associados a observações de campo, indicaram claramente que pastos mantidos mais altos apresentaram maiores comprimentos de bainha, o que poderia explicar o "atraso" no aparecimento de folhas sob aquelas circunstâncias. Apesar disso, as variações nas taxas de alongamento foliar (Tabela 31) e no filocrono (Tabela 10), associadas com os comprimentos médios da haste (Tabela 16), sugerem a existência de efeitos compensatórios durante a morfogênese de capimMarandu. Assim, durante as épocas de verão e final de primavera, quando os valores de filocrono foram bastante próximos e houve diferença nas taxas de alongamento, pastos mantidos a $40 \mathrm{~cm}$ apresentaram valores de filocrono cerca de $30 \%$ superiores àqueles mantidos a $10 \mathrm{~cm}$. Por outro lado, durante os períodos de outono, inverno e início de primavera as taxas de alongamento foram idênticas para todas as alturas, enquanto os valores de filocrono foram cerca de 129, 77,6 e 60\% superiores para a altura de $40 \mathrm{~cm}$ em relação àquelas mantidas a $10 \mathrm{~cm}$, respectivamente, indicando que o atraso maior no filoc rono foi decorrente das variações no $\mathrm{CPH}$ entre as alturas de dossel estudadas.

Como os valores de $\mathrm{CPH}$ praticamente não variaram ao longo do ano, as diferenças em filocrono devem ter refletido basicamente as variações em taxa de alongamento foliar. De fato, quando considerados de forma conjunta, a taxa de alongamento foliar e o filocrono apresentaram uma relação funcional de natureza exponencial altamente significativa e explicativa (Figura 41). Segundo essa relação, para taxas de alongamento superiores a 1,3 cm.perfilho ${ }^{-1} \cdot$ dia $^{-1}$ (até um limite genético estimado em torno de $2 \mathrm{~cm}$.perfilho ${ }^{-1} \cdot \mathrm{dia}^{-1}$ ) o filocrono tendeu a se estabilizar por volta de 10 a 12 dias.folha $^{-1}$. No outro extremo, ou seja, quando a taxa de alongamento foliar tende a zero, o filocrono aproximou-se de 100 dias. De acordo com Lemaire \& Chapman (1996), o tempo de alongamento é uma fração relativamente constante do intervalo de aparecimento de folhas. Dessa forma, seria esperado que reduções nos valores de filocrono resultassem em diminuição no tempo total de alongamento de folhas fazendo 
com que, para o mesmo tamanho final de folha, uma taxa de alongamento mais acelerada fosse necessária.

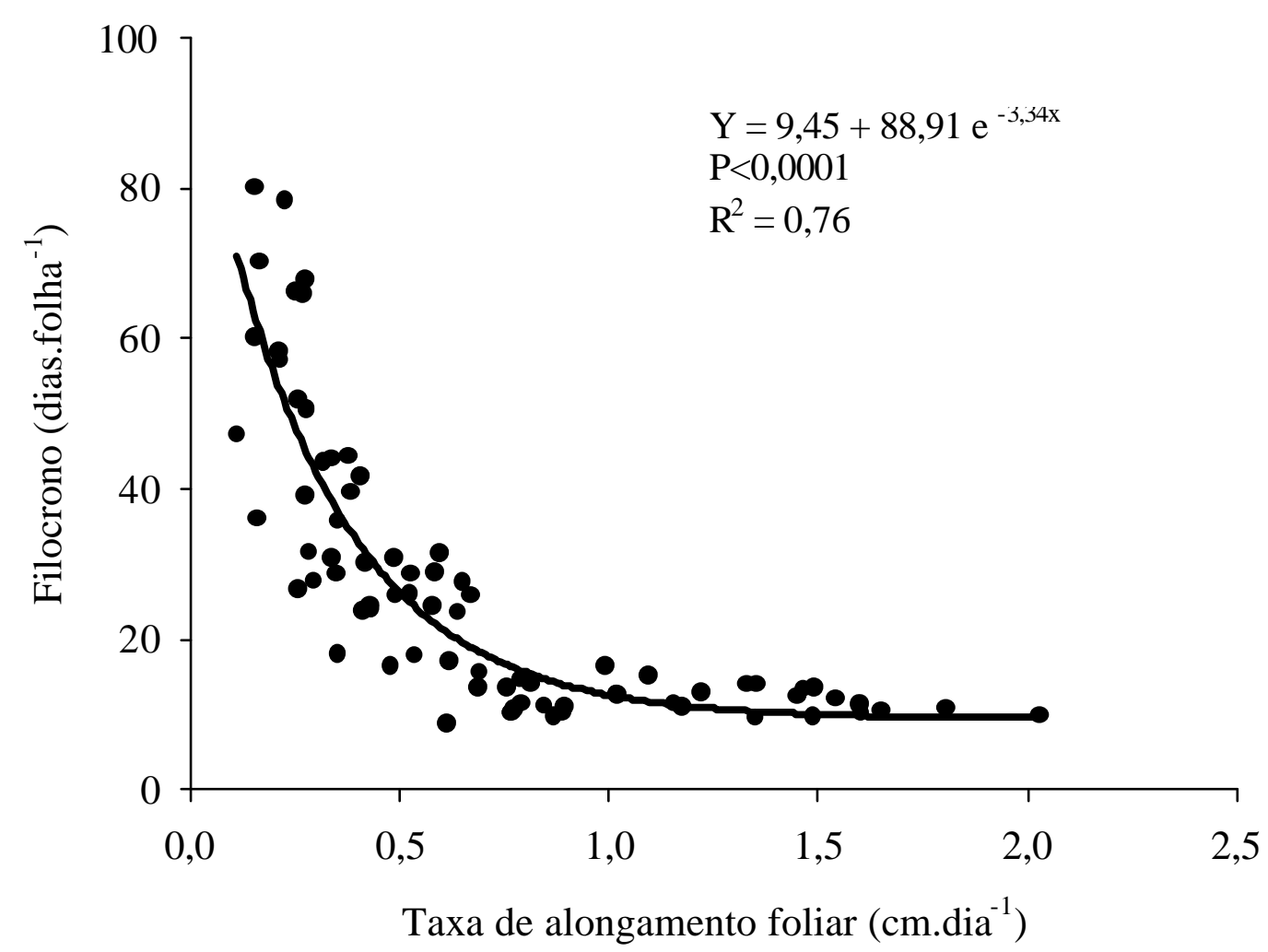

Figura 41 - Relação funcional entre a taxa de alongamento foliar e o filocrono em dosséis de capim-Marandu

Tanto a TAF quanto o filocrono avaliados em GD apresentaram variações entre as alturas de dossel e épocas do ano (Tabelas 9 a 11). O déficit hídrico, segundo alguns autores (Baker et al., 1986; Bauer et al., 1984), parece ter uma grande influência no filocrono. Além disso, conforme discutido por Bonhomme (2000), normalmente é assumida uma linearidade entre a taxa de crescimento e a temperatura, o que nem sempre é verdadeiro, sendo que a ausência de quaisquer outros fatores que possam interferir no desenvolvimento (e.g. água, luz etc) também pode refletir nas TAF e, conseqüentemente, no filocrono. Assim, com o avanço das estações a partir do verão, o filocrono em GD também foi aumentando, indicando que a temperatura, sozinha, pouco 
explica as TAF e, conseqüentemente, o filocrono. Infelizmente não foram encontrados trabalhos sobre a associação do desenvolvimento vegetativo e a soma térmica com capim-Marandu, de tal forma que os resultados aqui encontrados necessitam ser melhor estudados. Na tentativa de se verificar a incorporação de outra variável ambiental na predição da TAF e filocrono, foi usada a equação proposta por Villa Nova et al. (1983) em que o fotoperíodo é considerado, gerando o conceito de Unidades Fototérmicas (UF). Os resultados encontrados com a utilização da UF foram muito semelhantea àqueles obtidos para GD. Lemos-Filho et al. (1997) utilizaram o conceito de UF para predizer o crescimento de gemas de Hevea (a espécie não foi informada) e obtiveram uma melhor predição a partir da associação da UF em relação a GD. Na equação proposta por Villa Nova et al. (1983) o fotoperíodo entra como uma potência no numerador (eq. (8)).

$\mathrm{UF}=\frac{\frac{\mathrm{n}}{2} \overline{G D}^{\frac{\mathrm{N}_{\mathrm{f}}}{\mathrm{N}_{\mathrm{i}}}}+\frac{\mathrm{N}_{\mathrm{f}}}{\mathrm{N}_{\mathrm{i}}}+1}{1}$

onde;

$\mathrm{UF}=$ Número de Unidades Fototérmicas correspondente ao período de $n$ dias de avaliação;

GD = graus-dia médio do período de $n$ dias;

$\mathrm{N}_{\mathrm{f}}=$ Valor do fotoperíodo (horas e décimos) no final do período de crescimento, e $\mathrm{N}_{\mathrm{i}}=$ Valor do fotoperíodo no início do período de crescimento.

Assim, para períodos de avaliação longos a quantidade de UF acumulada é grande, o que pode ter superestimado os valores de filocrono baseados nessa unidade. Além disso, outro fator que pode ter influenciado a não adequação da UF foi a escassez de fatores de crescimento após o solstício de inverno, uma vez que a partir dessa data os dias vão se tornando mais longos, o que, matematicamente, "inflacionaria" os valores de 
UF. Essa afirmação pode parecer paradoxal, já que diversos trabalhos realizados com plantas de clima temperado têm encontrado associações entre soma térmica e eventos fenológicos (Davies \& Thomas, 1983; Duru et al., 1993). No entanto, no trabalho desenvolvido por Davies \& Thomas (1983) as associações entre a TAF e a temperatura (do solo) foram lineares até a temperatura de $14{ }^{\circ} \mathrm{C}$, sendo que para temperaturas acima desse valor nenhuma relação causal foi estabelecida. Os autores argumentaram que o não aumento na TAF poderia ter sido causado por estresse hídrico. Da mesma forma, os resultados obtidos por Duru et al. (1993) foram verificados em condições não limitantes de nitrogênio e água. Interessante observar que durante os períodos em que os fatores de crescimento não foram limitantes (final de primavera e verão) as diferenças na TAF e no filocrono foram relativamente pequenas $\left(122,7\right.$ e 113,7 graus-dia.folha $^{-1}$, respectivamente), indicando que o aparecimento de folhas em capim-Marandu foi relativamente constante em termos de graus-dia quando não houve outras limitações ambientais e/ou de ordem fisiológica (i.e. florescimento). No entanto, a não adequação do uso de GD e UF nos períodos de outono, inverno e início da primavera evidencia que, nessas épocas do ano, eventos fenológicos só poderão ser explicados por modelos multivariados onde água, intensidade e qualidade da luz e florescimento, entre outros, sejam considerados. Além disso, numa tabela apresentada por Lemaire \& Agnusdei (2000) comparando as TAF em graus-dia em plantas de fisiologia $\mathrm{C}_{3}$ e $\mathrm{C}_{4}$, os coeficientes de determinação para as regressões entre TAF e temperatura são menores para as plantas $\mathrm{C}_{4}$, um indicativo de que pode haver mais fatores ambientais determinando as TAF em plantas tropicais do que em plantas de clima temperado.

A longevidade de folhas deriva diretamente do filocrono e do NFV por perfilho. Como não houve variações grandes em NFV, pode-se afirmar que a longevidade foi basicamente uma resposta direta às variações no filocrono. A multiplicação dos dados de NFV e filocrono apresentados por Peternelli (2003) indica uma longevidade média de folhas de 49 dias durante o período de verão, valor praticamente idêntico ao obtido neste experimento para a mesma época do ano (Tabela 13). Folhas mais longevas poderiam, teoricamente, ser uma vantagem no sentido de permitir que essas fossem visitadas um maior número de vezes pelos animais enquanto vivas. No entanto, as maiores 
longevidades ocorreram em períodos onde foram verificadas também as menores taxas de acúmulo líquido (Tabela 38) e, conseqüentemente, as menores taxas de lotação (Andrade, 2004). As menores taxas de lotação certamente implicaram em freqüências de desfolhação de perfilhos individuais mais baixas (Gonçalves, 2003), de tal forma que os maiores valores de longevidade de folhas verificados nos períodos mais frios e secos do ano não seriam necessariamente uma vantagem no sentido de possibilitar uma maior eficiência de utilização da forragem produzida. Apesar disso, aumentos na longevidade de folhas possuem um aspecto ecológico importante. Como pode ser observado na Tabela 24, os valores de área foliar específica foram decrescentes a partir do verão até o início da primavera, um padrão de resposta exatamente oposto àquele observado para a longevidade de folhas. Alguns autores comentaram que a longevidade de folhas contribui mais para o tempo médio de permanência de nutrientes na planta que a translocação via senescência de folhas (Escudero et al., 1992; Aerts, 1995; Eckstein et al., 1999) e, segundo Ryser \& Urbas (2000), a curta longevidade de folhas em habitats produtivos seria uma consequiência inevitável da maximização do crescimento. Isso significa que com a redução na disponibilidade de fatores de crescimento, as folhas de capim-Marandu compactaram sua biomassa no sentido de aproveitar e aumentar a conservação de nutrientes, uma vez que absorção via solo estava comprometida em função da redução na disponibilidade de água. Diversos autores têm apontado a existência de uma relação inversa entre área foliar específica e longevidade de folhas para diferentes espécies (Van der Werf et al., 1998; Ryser \& Urbas, 2000; Casper et al., 2001) e normalmente tem-se assumido que folhas crescendo em ambientes pouco férteis são mais longevas (Ryser, 1996; Schlöpfer \& Ryser, 1996). A correlação entre a AFE e a longevidade de folhas em capim-Marandu foi significativa (Figura 42) e corrobora os resultados obtidos por esses autores. Apesar de a análise de solo ter evidenciado a não limitação de nutrientes para o crescimento do capim-Marandu (Tabela 1), o déficit hídrico verificado nos períodos de inverno e início de primavera pode ter caracterizado uma condição momentânea de baixa fertilidade já que a maior parte dos nutrientes ficaria indisponibilizada por faltar água para que sua absorção fosse efetivada. Certamente que essa "economia de nutrientes" por parte da planta só faz sentido se não 
houver remoção de folhas, ou seja, o ambiente deveria ser o menos perturbado possível e foi justamente nessas épocas do ano que foram registradas as menores taxas de lotação (Andrade, 2004). Uma conseqüência direta dessa provável "economia de recursos" foi o pequeno alongamento foliar verificado nas épocas mais secas do ano (Tabela 31), o que caracterizou um período de "quase dormência" dos perfilhos de capim-Marandu sob aquelas condições.

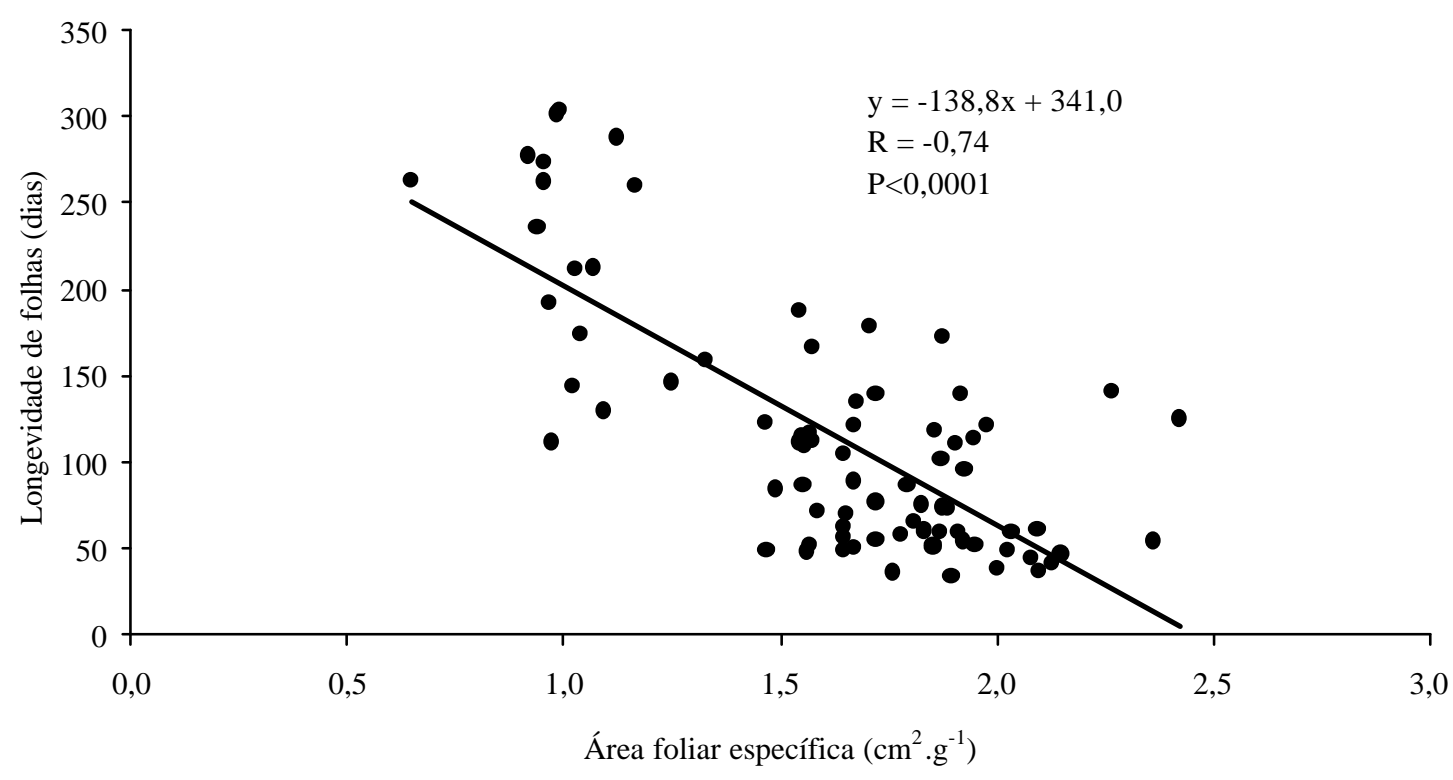

Figura 42 - Correlação entre a área foliar específica e longevidade de folhas de capimMarandu mantido em quatro alturas de dossel em diferentes épocas do ano

Assim como o filocrono avaliado em GD, a longevidade de folhas expressa na mesma base apresentou um comportamento semelhante (Tabela 14), indicando não haver uma correlação dessa variável com apenas uma única característica ambiental. 


\subsection{Perfilhamento}

Os padrões de resposta em relação às alturas de dossel estudadas e época do ano para os valores de densidade populacional de perfilhos (Tabela 17) são condizentes com vários dados disponíveis na literatura que indicam decréscimo na população de perfilhos à medida que os pastos são mantidos mais altos (Parsons et al., 1983a; Bircham \& Hodgson, 1983; Matthew et al., 1995; Sbrissia et al., 2001, 2003). Essa competição entre perfilhos ocorre particularmente por luz (Lonsdale \& Watkinson, 1982; SackvilleHamilton et al., 1995), ou seja, a baixa intensidade luminosa na base do relvado é, reconhecidamente, um dos principais fatores que poderia interferir com a capacidade de perfilhamento de pastos mantidos mais altos. Em trabalho conduzido na mesma área, de forma concomitante, Molan ${ }^{2}$ observou que a partir da altura de $20 \mathrm{~cm}$ os pastos de capim-Marandu já interceptavam mais que $95 \%$ da luz incidente. Dessa forma, fica evidente que a competição já estava ocorrendo e provavelmente induzindo uma mortalidade dependente de luz. Além disso, as folhas mais baixas, por crescerem num ambiente com pouca luz, têm seu potencial fotossintético reduzido, o que pode levar a uma condição de balanço negativo de carbono (Parsons et al., 1983a) e acelerar os processos de senescência e morte dessas folhas e dos perfilhos que as sustentam (Westoby, 1984; Sackville-Hamilton et al., 1995). Peternelli (2003) trabalhando com a mesma planta forrageira, verificou valores ligeiramente superiores de DPP em pastos submetidos a intensidades variáveis de pastejo rotacionado.

A variação estacional em densidade populacional foi causada basicamente por oscilações sazonais nas taxas de aparecimento e morte de perfilhos nas alturas de dossel avaliadas. As maiores taxas de aparecimento foram registradas em pastos mantidos mais baixos (Tabela 19), resultado basicamente da maior incidência de luz na base do dossel e das maiores taxas de aparecimento de folhas verificadas sob aquelas condições (Tabelas 8 e 9). Isso porque o surgimento de uma nova folha teoricamente gera a oportunidade para o desenvolvimento de um novo perfilho (Zarrough et al., 1984; Skinner \& Nelson,

\footnotetext{
${ }^{2}$ Molan, L.K. Estrutura do dossel, interceptação luminosa e acúmulo de forragem em pastos de capimMarandu sob lotação contínua. Dissertação de Mestrado em andamento.
} 
1992). Essa maior TAF registrada nos pastos mais baixos permitiria, teoricamente, um desenvolvimento mais rápido das gemas produzidas que, associado com a maior incidência de luz na base do dossel, estimularia o perfilhamento. Apesar disso, durante a época de verão e outono também foram registradas taxas altas de aparecimento de perfilhos em pastos mantidos a $40 \mathrm{~cm}$ (Tabela 19), o que poderia parecer incoerente com a observação acima. A manipulação mensal dos anéis de perfilhamento certamente superestimou os resultados, principalmente nos pastos mantidos mais altos, uma vez que permitiu a entrada de luz adicional no interior do dossel que outrora não chegaria à base dos pastos. Esse fato provavelmente estimulou o perfilhamento, principalmente durante a época de verão. A comparação entre os valores de densidade populacional medidos de maneira independente (Tabela 17) e aqueles oriundos dos anéis de perfilhamento (Figuras 18 a 21) sustenta esse argumento, uma vez que os valores provenientes dos anéis de perfilhamento foram consistentemente mais altos durante todo o experimento, particularmente para os pastos mantidos a 30 e $40 \mathrm{~cm}$. Outro fator que poderia estar influenciando a ocorrência de altas taxas de aparecimento de perfilhos nos pastos de 40 $\mathrm{cm}$ durante o verão e o outono é o florescimento, que ocorreu de forma mais acentuada sob aquelas condições (Tabela 18) e esteve associado a uma adubação nitrogenada realizada no começo do mês de março de 2002. Matthew et al. (2000), discutindo as estratégias de perenização de algumas espécies forrageiras, mostraram que diferentes espécies possuem estratégias variáveis de perenização. Assim, por exemplo, Phleum pratense L. apresentou um padrão de renovação de perfilhos associado com o florescimento, onde o aparecimento de novos perfilhos foi maior quando os perfilhos reprodutivos foram decapitados. Já no caso de Paspalum notatum Flugge (Hirata \& Pakiding, 2001), os perfilhos foram continuamente formados ao longo do ano, provavelmente a partir de perfilhos em estádio vegetativo. No caso do capim-Marandu, as maiores taxas de aparecimento ocorreram durante o período de verão e final de primavera (Tabela 19). Dada as possíveis interações entre o florescimento, adubações nitrogenadas realizadas durante o período de verão e melhoria das condições ambientais (no final da primavera em relação ao seu início), fica difícil estabelecer se o maior aparecimento de perfilhos foi uma resposta específica ao florescimento. Já as altas taxas 
de aparecimento verificadas durante o final da primavera podem estar basicamente associadas com o restabelecimento de condições de ambiente mais adequadas ao crescimento e produção da espécie estudada, uma vez que no período anterior houve restrições hídricas severas e as taxas de aparecimento foram as menores registradas durante todo o experimento.

Por outro lado, tradicionalmente tem-se sugerido que a qualidade da luz, principalmente uma alta relação vermelho: verme lho longo (V:VL), estimula o perfilhamento. Essa afirmativa é basicamente amparada pelos trabalhos desenvolvidos por Deregibus et al. $(1983 ; 1985)$ e Casal et al. (1985) e amplamente corroborada por diversos autores (Skalová \& Krahulec, 1992; Gautier et al., 1999; Skalová et al., 1999). No entanto, Wan \& Sosebee (1998), trabalhando com Eragrostis curvula (Schrad.) Nees, verificaram que a influência da qualidade da luz no perfilhamento variou com o estádio fenológico das plantas. Segundo esses autores, o estímulo ao perfilhamento foi mais evidente em plantas no estádio vegetativo e menos significativo para plantas no estádio reprodutivo, resultados diferentes daqueles encontrados por Casal et al. (1985), que reportaram respostas semelhantes para ambos os estádios de desenvolvimento em Lolium multiflorum Lam. De qualquer forma, parece haver consenso entre os pesquisadores que comprimentos de luz na faixa do vermelho (particularmente uma alta relação V:VL) estimulem o perfilhamento durante o estádio vegetativo de gramíneas, apesar das razões para esse efeito ainda serem obscuras (Nelson, 2000). Em relação ao período reprodutivo, os resultados sobre os efeitos das altas e baixas relações V:VL sobre o alongamento de hastes e formação de inflorescências são contraditórios (Badila et al., 1985; Myers et al., 1987; Novoplansky et al., 1990; Wan \& Sosebee, 1998). Da mesma forma, ainda não existem evidências claras relativas aos efeitos da luz azul no estímulo ao perfilhamento. Barnes \& Bugbee (1992) reportaram decréscimo no número de perfilhos por planta em trigo como resposta a reduções em luz azul. Por outro lado, Gautier et al. (1999) não registraram o mesmo efeito em plantas de azevém perene e salientaram que um possível efeito da luz azul sobre o perfilhamento poderia se dar de forma indireta, já que esta havia afetado as características morfogênicas de azevém e festuca. 
Além da qualidade da luz, historicamente temse discutido o papel da dominância apical na regulação do perfilhamento e, especialmente, na iniciação de perfilhos como resposta à desfolhação. Normalmente é assumido que a remoção do meristema apical estimula o desenvolvimento de gemas e promove a iniciação de perfilhos. No entanto, diversos trabalhos têm mostrado inconsistências em relação ao estímulo do perfilhamento via remoção do meristema apical (Langer, 1958; Vogel \& Bjugstad, 1968; Cable, 1982; Olson \& Richards, 1988). Butler \& Briske (1988) mostraram que o estímulo ao perfilhamento pode ocorrer em resposta à desfolhação (ou pastejo) mesmo quando os meristemas apicais não forem removidos. Murphy \& Briske (1992) comentaram que variáveis ambientais podem desempenhar um papel tão importante quanto os fatores hormonais no desenvolvimento de gemas e consequente estímulo no perfilhamento. Adicionalmente, alguns autores têm sugerido que nutrientes também possam assumir importância no desenvolvimento das gemas (Prasad et al., 1989; McIntyre \& Cessna, 1991). Por exemplo, Aspinall (1961) demonstrou que a iniciação de perfilhos em cevada foi reduzida sob níveis baixos de nitrogênio e que o perfilhamento poderia ser estimulado a qualquer tempo com a adição desse nutriente. Outros pesquisadores têm demonstrado ainda a importância da água (Cottignies \& Jenmane, 1988) no estímulo ao perfilhamento, de tal forma que as aparentes contradições dos resultados de pesquisa são por si só bastante sugestivas da integração de fatores regulando o perfilhamento.

A remoção de meristemas apicais tem sido sugerida como forma de estimular o perfilhamento em algumas gramíneas tropicais. A incongruência dos dados disponíveis na literatura mostra que a remoção per se pode ter um efeito pequeno sobre tais processos. No entanto, isso não invalida a prática de remoção, uma vez que o reconhecido alongamento de hastes em gramíneas tropicais (Santos, 2002; Carnevalli, 2003) seria restringido, o que já seria um efeito benéfico para o manejo e manutenção de altas produtividades e melhoria do valor nutritivo da forragem produzida.

Os pastos mantidos a $10 \mathrm{~cm}$ apresentaram as maiores taxas de aparecimento e também de mortalidade de perfilhos (Tabela 21). Diversos estudos têm relatado maiores taxas de mortalidade associadas com pastejos mais intensos (Matthew, 1992; Korte et 
al., 1984; Hernández-Garay et al., 1999; Carvalho et al., 2000a, 2000b, 2001) e também associadas com altas taxas de aparecimento (Briske, 1991). Além disso, as taxas mais altas de mortalidade ocorreram durante o período de verão e outono (Tabela 21), da mesma forma que as taxas de aparecimento (Tabela 19). De maneira inversa às taxas de mortalidade de perfilhos, as maiores taxas de sobrevivência foram registradas durante os períodos mais secos e frios do ano (Tabela 20). Isso evidencia claramente um mecanismo compensatório que tende a limitar a população de perfilhos numa dada condição, ou seja, com o objetivo de compensar uma redução nas taxas de aparecimento, os perfilhos tendem a sobreviver por mais tempo a fim de manter estável a população de plantas e garantir sua persistência na área.

As variações sazonais nas taxas de aparecimento e mortalidade de perfilhos são fundamentais na compreensão dos mecanismos envolvidos na perenização e renovação de perfilhos em pastagens. Apesar disso, a simples observação das taxas de aparecimento e sobrevivência (ou mortalidade) de perfilhos não indica se numa dada época do ano a população de perfilhos foi mantida estável, ou seja, se o aparecimento de perfilhos foi suficiente para manter a população de perfilhos em equilíbrio. A fim de uma análise integrada das taxas de aparecimento e sobrevivência de perfilhos, SackvilleHamilton e colaboradores (trabalho não publicado) desenvolveram, a partir de matrizes algébricas estudadas por Leslie (1945) para o estudo de dinâmica de populações, um índice baseado na relação entre a taxa de aparecimento e a taxa de sobrevivência de perfilhos, que aqui será chamado de "índice de estabilidade". Os primeiros dados com esse tipo de análise foram publicados a partir de um estudo com azevém perene (Bahmani et al., 2003). Basicamente, se o índice for menor que 1, significa que os pastos naquele mês (ou época do ano) têm sua estabilidade comprometida, uma vez que não estão sendo eficazes em repor perfilhos em número suficiente relativamente à sobrevivência dos perfilhos existentes. Os diagramas de estabilidade foram gerados para cada época de avaliação estudada, bem como para cada mês do ano (Figuras 22 a 29). Durante o verão, apesar de os pastos mantidos a $10 \mathrm{~cm}$ apresentarem as maiores taxas de aparecimento, essas não foram altas o suficiente para compensar a alta mortalidade, ou seja, a sobrevivência de perfilhos foi muito baixa, o que poderia comprometer a 
persistência e produtividade dos pastos (Figura 22). De maneira contrária, a partir do mês de abril até agosto (outono/inverno), apesar das taxas de aparecimento serem baixas nesses pastos, a sobrevivência de perfilhos foi alta, o que resultou num aumento do índice de estabilidade para níveis próximo de 1 durante o inverno (Figura 26). Já pastos mantidos a 20, 30 e $40 \mathrm{~cm}$ apresentaram se relativamente estáveis ao longo do ano (Figuras 23 a 25), sendo que apenas durante o inverno (e outono para pastos mantidos a $20 \mathrm{~cm}$ ) foram registradas quedas nos índices de estabilidade. $\mathrm{O}$ aumento nos índices de estabilidade durante o final da primavera evidenciam a capacidade de perfilhamento e recuperação do capim-Marandu quando as condições de temperatura, luminosidade e pluviosidade são restabelecidas (Figuras 26 a 29).

Os resultados indicam que manter pastos baixos (abaixo de $10 \mathrm{~cm}$ ) durante o período de verão pode ser extremamente prejudicial para a produtividade e persistência do capim-Marandu, uma vez que não há suficiente reposição de perfilhos para manter a população de plantas na área numa época em que sua sobrevivência é baixa. Dada a duração do experimento de apenas um ano, não seria recomendável afirmar que pastos mantidos mais baixos teriam sua perenidade comprometida no longo prazo. No entanto, observações visuais das unidades experimentais mostraram que pastos mantidos a $10 \mathrm{~cm}$ apresentaram uma baixa habilidade competitiva, uma vez que havia sinais de invasão de plantas daninhas, fato que não ocorreu para as outras alturas de dossel estudadas. Apesar dos valores super estimados para as taxas de aparecimento nos pastos mantidos a 30 e 40 $\mathrm{cm}$ (principalmente), os resultados indicam que uma baixa população de perfilhos não deve ser considerada de maneira isolada como um reflexo de perda do potencial produtivo ou de redução na persistência, uma vez que os pastos podem manter-se estáveis mesmo com valores baixos de densidade populacional de perfilhos.

\subsection{Características de perfilhos individuais}

As maiores áreas foliares registradas em perfilhos oriundos de pastos mantidos mais altos foram uma consequiência direta dos limites plásticos impostos para essa 
característica, ou seja, tanto o comprimento de folhas (Tabela 15) quanto a área foliar (Tabela 22) tiveram que se adaptar às reduções em altura do dossel por meio do "encurtamento" de suas lâminas foliares. Segundo Huber et al. (1999), a plasticidade fenotípica pode ser definida como mudanças no tamanho, estrutura e posicionamento espacial dos órgãos, impostas por variações de ambiente, na morfologia e arquitetura que não são devidas à ontogenia. Assim, adaptações de caráter fenotípico são transitórias e reversíveis.

Outro exemplo típico de adaptação foi a reduzida área foliar por perfilho durante o início da primavera (Tabela 22), ou seja, numa época em que praticamente não houve crescimento (pequenas taxas de alongamento foliar), como forma de adaptação às condições ambientais, os perfilhos passaram a produzir folhas com área de limbo reduzida.

Os maiores valores de massa dos perfilhos foram registrados em perfilhos oriundos de pastos mantidos mais altos (Tabela 23). Esse fato, associado com as maiores densidades populaciona is observadas em pastos mais baixos, evidencia a existência de um mecanismo de compensação em pastos de capim-Marandu, mecanismo esse amplamente descrito na literatura (Grant et al., 1983; Bircham \& Hodgson, 1983; Sbrissia et al., 2001, 2003) segundo o qual pastos mantidos mais baixos possuem uma maior densidade populacional de perfilhos pequenos e vice-versa. Além disso, os perfilhos de capim-Marandu foram mais pesados no início da primavera. Provavelmente o maior tamanho de perfilhos nessa época do ano foi devido a dois fatores: (1) maior quantidade de tecidos mortos aderidos nos perfilhos (Figuras 30 a 33) e (2) acúmulo de biomassa resultante de restrições nas condições de ambiente. Assim, como o crescimento proveniente de folhas (Tabela 34) e hastes (Tabela 35) foi muito pequeno, boa parte do material produzido via fotossíntese deve ter sido acumulada, sem gerar crescimento correspondente.

A relação folha: haste $(\mathrm{FH})$ e a razão área foliar: volume $(\mathrm{R})$ dos perfilhos apresentaram comportamentos distintos. Enquanto a FH diminuiu com o aumento da altura de dossel, o valor de $\mathrm{R}$ aumentou (Tabelas 27 e 28). A razão área foliar: volume (R) foi proposta por Sackville-Hamilton et al. (1995). Em seu cálculo a área foliar dos 
perfilhos é elevada à potência de $3 / 2$ a fim de tornar seu valor adimensional. Segundo Hernández-Garay et al. (1999), avaliações da relação folha: haste por perfilho são impróprias para efeito de cálculos da compensação tamanho/densidade populacional de perfilhos pelo fato de que folha e haste são componentes da planta que possuem dimensões diferentes e a relação folha: haste não leva essas diferenças em consideração (a haste, tridimensional e a folha pode ser considerada bidimensional). Em outro contexto, outros autores (e.g. Louie et al., 1998) mostraram algumas vantagens de se introduzir parâmetros adimensionais para descrever sistemas biológicos. Dessa forma, aumentos em altura do dossel quase sempre conduzem a uma redução concomitante na relação folha: haste por perfilho pelo fato de que, para suportar o peso de um órgão (no caso as folhas), o diâmetro das estruturas de suporte (no caso as hastes) altera-se em proporção direta à força requerida para suportá-lo e não isometricamente com o seu peso (McMahon, 1973; McMahon \& Kronauer, 1976; Niklas, 1994). No presente experimento, os valores de $\mathrm{R}$ aumentaram com o aumento nas alturas de dossel. A variação em $\mathrm{R}$ significa que conforme o dossel aumentou em altura, perfilhos individuais mudaram sua forma, ocorrendo um aumento maior para o componente folha relativamente ao componente haste, apesar da redução na relação folha: haste por perfilho calculada com base em massa apenas. Hernández-Garay et al. (1999) reportaram valores de $\mathrm{R}$ próximos de 50 para azevém perene, sendo que este cresceu à medida que a altura do dossel era aumentada, indicando que em azevém perene ocorrem modificações na forma do perfilho que correspondem a um aumento maior em área foliar relativamente ao comprimento da haste à medida que as plantas aumentam em tamanho, da mesma forma como encontrado no presente experimento. No entanto, neste caso os valores máximos de $\mathrm{R}$ foram mais elevados (Tabela 28). Já para os capins Coastcross e Tifton-85, Sbrissia et al. $(2001,2003)$ encontraram valores de R por volta de 17.

Segundo Matthew et al. (2000), variações interespecíficas em R poderiam ter algumas implicações ecológicas. Segundo esses autores, plantas com valores maiores de $\mathrm{R}$ podem ter uma maior habilidade competitiva (tolerância ao pastejo) enquanto que plantas com valores menores de $\mathrm{R}$ poderiam ser mais resistentes a estresses, pois uma 
menor razão área foliar: volume seria uma forma da planta evitar perda de água, por exemplo. $\mathrm{O}$ baixo valor de $\mathrm{R}$ encontrado durante o início da primavera (quando comparado às outras épocas do ano) pode ser um indicativo de que além das variações interespecíficas comentadas por Matthew et al. (2000) podem existir variações intraespecíficas, como uma resposta às modificações de ambiente. No caso do capimMarandu, os perfilhos, provavelmente na tentativa de reduzir a perda de água, reduziram sua área foliar relativamente ao seu volume, indicando uma capacidade adaptativa plástica muito interessante do ponto de vista de estratégia de perenização e sobrevivência para essa planta.

As diferentes metodologias empregadas no cálculo de $\mathrm{R}$ (Tabelas 28 e 29) tiveram o objetivo de comparar estimativas provenientes do uso de valor genérico aproximado ou valor exato de densidade aparente e volume dos perfilhos. Como pode ser observado (Tabelas 28 e 29), durante o inverno e início da primavera.os valores de $\mathrm{R}$ calculados com base no volume efetivamente medido foram maiores que aqueles calculados com a densidade constante. Isso ocorreu justamente porque nesses períodos os valores de densidade aparente calculados foram superiores a $950 \mathrm{~kg} \cdot \mathrm{m}^{-3}$ (Tabela 26), o que acabou elevando os valores de R. Pelo motivo contrário, durante o final da primavera os valores de $\mathrm{R}$ calculados com base no volume medido foram um pouco maiores que aqueles calculados com base em densidade constante, ou seja, a densidade aparente foi menor que $950 \mathrm{~kg} \cdot \mathrm{m}^{-3}$ durante aquela época do ano. Essa variação em densidade aparente evidencia que os cálculos de $\mathrm{R}$, sempre que possível, deveriam ser feitos com base no volume efetivamente medido, uma vez que a densidade aparente dos perfilhos variou com as alturas de dossel e épocas do ano analisadas (Tabela 26).

\subsubsection{Metodologia para mensuração de volume de perfilhos}

O instrumento construído para determinação de volume de perfilhos, apesar de simples, mostrourse extremamente eficaz para o seu propósito. Apesar de não existirem dados disponíveis para comparação, as medições evidenciaram maiores valores de 
volume (Tabela 25) para perfilhos mais pesados (Tabela 23), o que seria esperado. Os resultados de densidade aparente dos perfilhos revelaram valores que oscilaram de 921 kg. $\mathrm{m}^{-3}$ para perfilhos de pastos mantidos a $10 \mathrm{~cm}$ a $972 \mathrm{~kg} \cdot \mathrm{m}^{-3}$ para pastos mantidos 20 , 30 e $40 \mathrm{~cm}$, em média. Sackville-Hamilton et al. (1995) reportaram valores de 900 kg.m ${ }^{-3}$ para perfilhos de azevém perene e Sbrissia et al. (2001; 2003) estimaram valores de $950 \mathrm{~kg} . \mathrm{m}^{-3}$ para perfilhos de cultivares de Cynodon. Esses últimos autores estimaram o volume dos perfilhos imergindo-os em líquidos de densidades aparente conhecidas, água (1000 kg. $\left.\mathrm{m}^{-3}\right)$ e um óleo lubrificante $\left(902 \mathrm{~kg} \cdot \mathrm{m}^{-3}\right)$. Como os perfilhos flutuaram na água e submergiram no óleo, assumiram densidade de $950 \mathrm{~kg} \cdot \mathrm{m}^{-3}$. Sackville-Hamilton et al. (1995), no entanto, não descreveram a metodologia utilizada. Contudo, Matthew ${ }^{3}$ comentou que foram utilizadas soluções com diferentes densidades e os perfilhos submergidos nelas. Os valores de densidade obtidos a partir da metodologia utilizada neste experimento foram semelhantes àqueles obtidos por esses autores (de maneira empírica), indicando que medições de volume podem ser realizadas de forma bastante acurada. Para a estimativa do volume dos perfilhos, foram utilizadas as folhas e as hastes. Folhas mortas não foram incluídas em função da alta variabilidade das medidas, ocasionadas, principalmente, pelos teores variá veis de umidade nas mesmas.

Uma outra forma utilizada para testar a metodologia utilizada ("volumímetro") foi realizar uma regressão linear simples entre o volume e a área das folhas (Figura 43). Nesse caso, o coeficiente angular da regressão corresponderia à espessura média das lâminas foliares. Arredondo \& Schnyder (2003), trabalhando com 8 espécies de gramíneas, encontraram valores de espessura das folhas variando de 0,14 mm para Brachypodium pinnatum (L.) P. Beauv. a 0,27 mm para Avena pubescens Huds.. Esses autores calcularam a espessura das folhas a partir da suposição de que seu volume era aproximadamente igual à sua massa "fresca" $\left(10^{6} \mathrm{~g}\right.$ massa "fresca" $\left.1 \mathrm{~m}^{3}\right)$, sendo que a espessura média foi estimada a partir do quociente entre o volume e a área das folhas. Além disso, Ryser \& Urbas (2000) estimaram a espessura de 32 espécies de gramíneas por meio de medições eletrônicas (com resolução de $0,01 \mathrm{~mm}$ ) e encontraram valores que variaram de 0,07 a 0,52 $\mathrm{mm}$. A folhas de capim-Marandu tiveram valores de

\footnotetext{
${ }^{3}$ Cory Matthew, Massey University. Informação pessoal.
} 
espessura muito próximos $(0,21 \mathrm{~mm})$ daqueles observados por Arrendondo \& Schnyder (2003) e dentro da faixa encontrada por Ryser \& Urbas (2000), indicando que as avaliações de volume de folhas podem ser realizadas de maneira adequada com o equipamento utilizado.

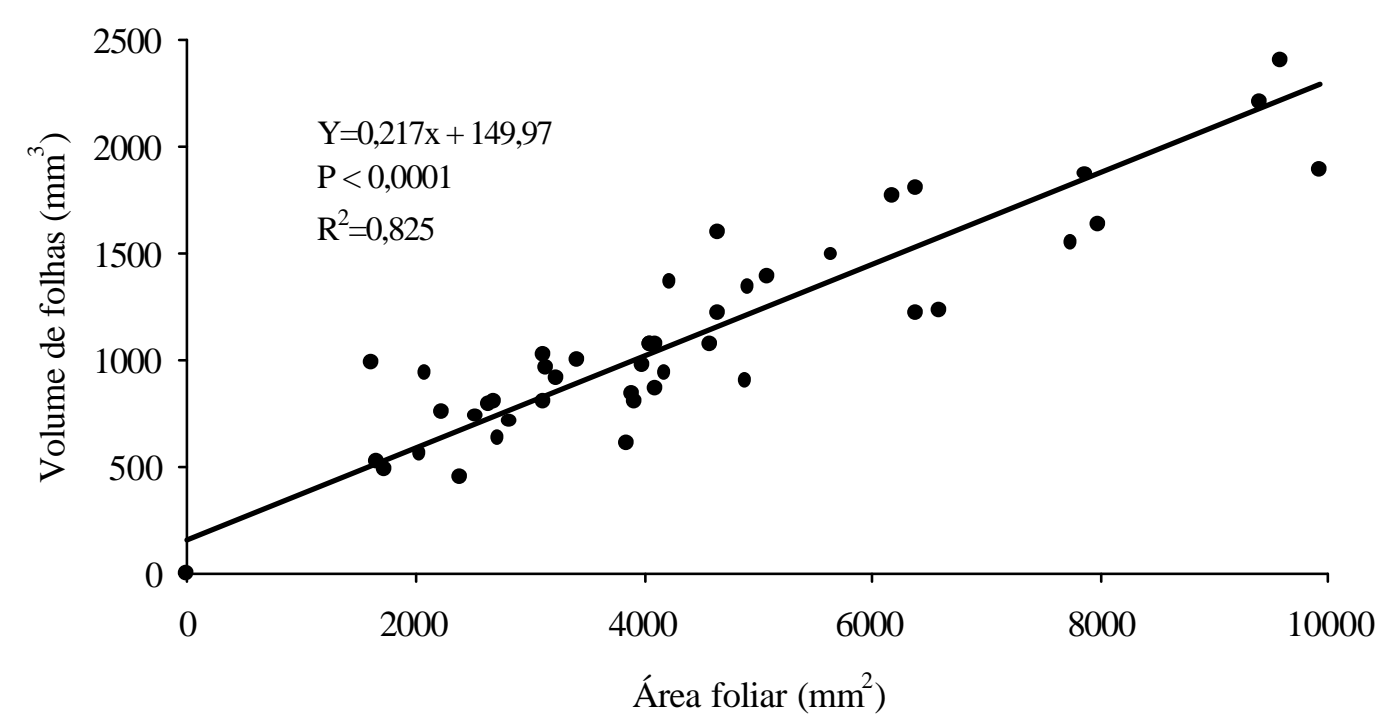

Figura 43 - Relação funcional entre a área e o volume de folhas em capim-Marandu

Normalmente, massa e comprimento êm sido as variáveis mais utilizadas na descrição de tamanho de plantas (ou perfilhos). O volume, dadas as dificuldades de sua estimativa, não tem sido usado para esse propósito. Contudo, a metodologia aqui proposta mostrourse simples e suficientemente adequada para sua estimação. A possibilidade de se obter uma medida tridimensional do tamanho das plantas ou perfilhos pode trazer novas percepções em termos de competição e ocupação espacial de plantas e também novas possibilidades na compreensão dos mecanismos envolvidos na compensação tamanho/densidade populacional de perfilhos em pastagens. 


\subsection{Dinâmica do acúmulo}

As taxas de alongamento de folhas diferiram entre os tratamentos e foram mais altas durante o verão e final de primavera (Tabela 31), épocas de reconhecida disponibilidade de fatores de crescimento. No entanto, durante o verão as taxas de alongamento aumentaram com a altura do dossel até $30 \mathrm{~cm}$, diferentemente do final de primavera em que a maior taxa de alongamento foi registrada para os pastos mantidos a $40 \mathrm{~cm}$. Isso pode ter sido um reflexo direto de tamanhos de lâminas foliares semelhantes para as alturas de 30 e $40 \mathrm{~cm}$, bem como valores semelhantes de IAF (Tabela 30). Já durante os períodos de outono, inverno e início da primavera não foram detectadas diferenças entre os tratamentos (Tabela 31). Essa ausência de diferenças e os valores reduzidos de taxa de alongamento foliar evidenciam a restrição de fatores de crescimento. Durante o início da primavera a redução no número de folhas em expansão por perfilho (Tabela 5) também pode ter contribuído para a redução na taxa de alongamento de folhas. Durante essa época do ano a taxa de alongamento foi cerca de 6 vezes menor que os valores registrados durante o verão e final de primavera, evidenciando a extrema sazonalidade no crescimento do capim-Marandu. Como a taxa de senescência foliar foi crescente com as alturas de dossel (Tabela 32) e apresentou um relativo aumento ao longo das estações a partir do verão, seria esperado que durante as épocas em que não houve diferença em crescimento tenha havido um desbalanço entre produção (crescimento) e senescência, reduzindo as taxas de acúmulo líquido (Tabela 38). As taxas de alongamento diário de haste expressas com base em variação de comprimento foram muito pequenas (média de $0,03 \mathrm{~cm} \cdot$ perfilho ${ }^{-1} \cdot$ dia $^{-1}$ ), razão pela qual se optou por não apresentá-las no item Resultados. Sua contribuição em kg de MS.ha ${ }^{-1}$ foi aumentada pelo fato de que os fatores de conversão de comprimento para massa foram superiores àqueles calculados para folhas $\left(0,0258\right.$ e 0,0065 g.cm ${ }^{-1}$, respectivamente).

O significado isolado das taxas de alongamento foliar tem um efeito limitado no sentido de explicar processos de crescimento em ambientes pastoris. Isso porque não existe um perfilho isolado no campo, razão pela qual as taxas dos processos devem ser 
consideradas na população de perfilhos como um todo. Como os valores de DPP foram variáveis para as alturas de pasto e épocas do ano estudadas, é natural que as respostas em termos de crescimento ( $\mathrm{kg}$ de $\mathrm{MS} \cdot \mathrm{ha}^{-1}$ ) apresentassem padrões de comportamento relativamente diferentes daqueles obtidos para perfilhos isolados. Quando considerada a população de perfilhos, as taxas de crescimento de folhas foram maiores para as alturas de $30 \mathrm{~cm}$ (Tabela 34), não havendo diferenças entre as demais alturas estudadas. No entanto, concomitante ao processo de crescimento de folhas, ocorre o crescimento de hastes, que pode representar até $80 \%$ do crescimento total de gramíneas do gênero Cynodon (Pinto et al., 2001). No caso do capim-Marandu, as hastes chegaram a responder por até $30 \%$ do crescimento dos pastos mantidos a $40 \mathrm{~cm}$ durante o verão e final da primavera (Tabela 35). Comportamento exatamente inverso ocorreu durante o inverno e início da primavera, ou seja, houve uma participação negativa de hastes no crescimento total, indicando que durante essa época do ano os perfilhos tendem a colocar as novas folhas abaixo da última folha completamente expandida, caracterizando uma redução no comprimento da haste e, conseqüentemente, contribuindo com crescimento negativo. Carnevalli (2003) também observou processo semelhante para capim-Mombaça durante as épocas mais secas do ano. A taxa de senescência apresentou um aumento linear com as alturas de dossel estudadas, estabilizando-se por volta da altura de $30 \mathrm{~cm}$, ou seja, dosséis mantidos a $40 \mathrm{~cm}$ apresentaram maiores taxas de senescência que pastos de $30 \mathrm{~cm}$ apenas no final da primavera (Tabela 37). Lemaire \& Agnusdei (2000) comentaram que a taxa de alongamento foliar responde imediatamente a qualquer mudança em temperatura, de tal forma que a produção de tecidos segue exatamente suas variações sazonais. No entanto, esses mesmos autores comentaram que a taxa de senescência não responde imediatamente a essa variação, uma vez que a porção da folha que senesce a cada dia corresponde à porção de uma folha produzida em período equivalente a um ciclo anterior de vida das folhas. Assim, essa assincronia entre produção e senescência de folhas resultou em reduções no acúmulo líquido de forragem a partir do verão, uma vez que com o início das estações mais frias e secas do ano as taxas de alongamento foram reduzindo e, no entanto, as taxas de senescência foram aumentando, resultado não de maiores comprimentos de lâminas foliares (Tabela 15) 
mas de diferenças em longevidade de folhas (Tabela 13). Assim, durante os períodos de verão, outono e inverno as taxas de senescência foram relativamente constantes (Tabela 37) pelo fato de que a longevidade dessas folhas foi menor durante os períodos de verão e outono (Tabela 13). Já os aumentos na taxas de senescência durante o início e final da primavera foram o resultado de maior longevidade de folhas registrada durante o inverno e início da primavera, as quais vieram a senescer no período subsequente. Além disso, a longevidade de folhas de 227 dias verificada nos pastos no início da primavera não significa necessariamente que esse seria o período de tempo necessário para a folha entrar em processo de senescência. Isso só seria verdade se as condições climáticas permanecessem semelhantes àquelas quando as folhas foram formadas. Com os aumentos em temperatura, regime hídrico e adubação nitrogenada, as folhas poderiam ter entrado imediatamente em processo de senescência, translocando nutrientes para auxiliar na expansão de folhas novas. Além disso, aumentos ou reduções na taxa de senescência foliar podem ser o reflexo direto de variações em altura do dossel ocasionadas por variações em taxa de lotação. Como não foi possível a permanência de animais durante o todo o tempo nas parcelas ao longo do período experimental (principalmente nos pastos mantidos mais altos), a remoção das folhas quando esses eram colocados nos piquetes necessariamente implicou em mudanças nas taxas de senescência equivalentes a uma longevidade à frente. Assim, durante o período de verão, época em que as folhas surgiram e morreram no mesmo período (Tabela 13), as reduções nas taxas de senescência nos pastos de $40 \mathrm{~cm}$ podem ter sido o reflexo das reduções em altura provocadas pela permanência demasiadamente longa dos animais nesses pastos. Já para os pastos mantidos a 10 e $20 \mathrm{~cm}$, onde as alturas variaram pouco e a presença dos animais foi mais constante, as taxas de senescência provavelmente foram mais próximas da realidade. Da mesma forma, durante o período de início de primavera, pastos mantidos a $40 \mathrm{~cm}$ praticamente não chegaram a ser pastejados (Andrade, 2004), de forma que no período seguinte, as folhas existentes senesceram com aproximadamente o mesmo tamanho final, resultando em aumentos nas taxas de senescência. 
Análise conjunta das taxas de crescimento, senescência e acúmulo líquido revelou que durante o período de verão e final de primavera o balanço líquido entre os componentes resultou em máximas taxas de acúmulo líquido já a partir da altura de 20 cm (Tabela 38), ou seja, do ponto de vista da planta, não haveria razões para o manejo do pastejo em alturas superiores a essa. No entanto, nos períodos mais frios e secos do ano, a relação se inverteu, ou seja, acúmulos líquidos máximos foram atingidos nos pastos mantidos mais baixos. A implicação direta disso é que o capim-Marandu exigiria mudanças sazonais no seu manejo, de forma que no período de inverno os pastos deveriam ser manejados mais baixos, provavelmente em torno de $15 \mathrm{~cm}$. Interessante ressaltar que na prática poucos produtores variam a taxa de lotação ao longo do ano, o que de certa maneira provoca oscilações "naturais" em altura do dossel. Essa situação conduz a uma realidade onde os pastos são mantidos mais baixos nas épocas mais secas do ano o que, mesmo inadvertidamente, poderia explicar o sucesso e aceitação desse capim por parte dos produtores.

As taxas de remoção de forragem foram iguais para os pastos mantidos a 10, 20 e $30 \mathrm{~cm}$, diferindo apenas daqueles dos pastos mantidos a $40 \mathrm{~cm}$ (Tabela 41). A eficiência de pastejo pode ser definida como sendo a forragem removida expressa como uma proporção da forragem acumulada (Hodgson, 1979). Em condições de equilíbrio, onde o acúmulo aparente de forragem é teoricamente nulo (crescimento menos senescência e desfolhação), a eficiência de pastejo é igual a 1 menos a proporção entre senescência e crescimento (Bircham \& Hodgson, 1983). De forma alternativa, inferências sobre a eficiência de utilização da forragem nas condições de pasto estudadas podem ser feitas a partir da relação entre as taxas de remoção de forragem (Tabela 41) e as de crescimento (Tabela 36). A Figura 44 mostra que essa relação foi maior para as alturas mais baixas de dossel, evidenciando uma eficiência real de utilização mais alta nos pastos mantidos a 10 e $20 \mathrm{~cm}$. 


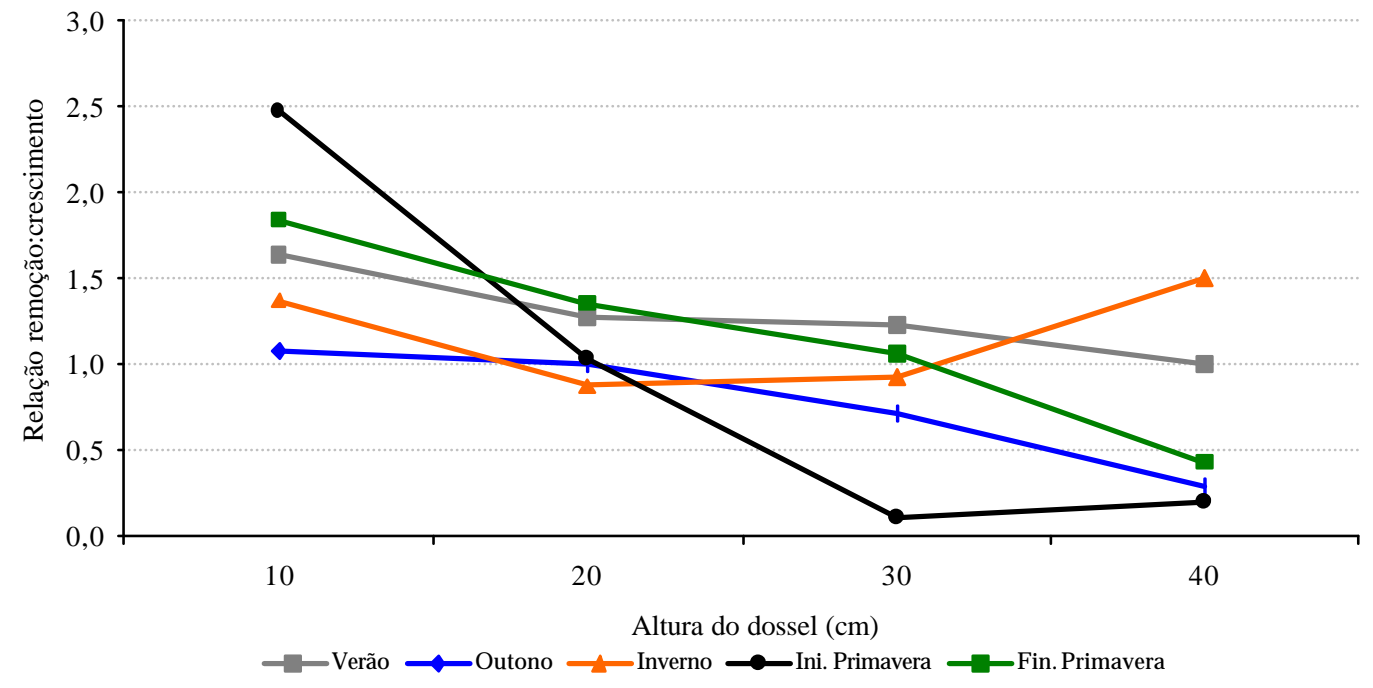

Figura 44 - Relação entre as taxas de remoção de forragem e de crescimento em pastos de capim-Marandu submetidos a quatro alturas de pastejo por meio de lotação contínua.

Nesse caso, eficiências maiores que 1 indicam que: (1) agentes externos (que não o pastejo em si) contribuíram para a remoção de forragem (insetos, pisoteio etc.), (2) a adição e retirada de animais dos piquetes geraram uma condição em que os pastos sofreram variações instantâneas em altura do dossel ou, ainda, que, (3) a freqüência de entrada e saída dos animais afetou o equilíbrio entre as taxas dos processos de crescimento, senescência e remoção de forragem, mesmo nas situações em que as alturas do dossel foram mantidas relativamente constantes por um período de tempo maior. As eficiências menores que 1 (registradas na maior parte dos casos nos pastos mantidos a 30 e $40 \mathrm{~cm}$ ) indicam que durante algum período de tempo os pastos cresceram sem a presença de animais ou estes permaneceram na área por períodos de tempo muito curtos.

Uma outra forma de se avaliar a utilização de forragem nas condições deste experimento seria considerar a relação entre as taxas de senescência (Tabela 37) e crescimento de forragem (Tabela 36), ou seja, a diferença desse quociente em relação ao valor 1 indicaria a proporção da forragem produzida que potencialmente poderia ser 
consumida pelos animais caso os pastos estivessem mantidos em equilíbrio (Mazzanti \& Lemaire, 1994; Louault et al., 1997) (Figura 45).

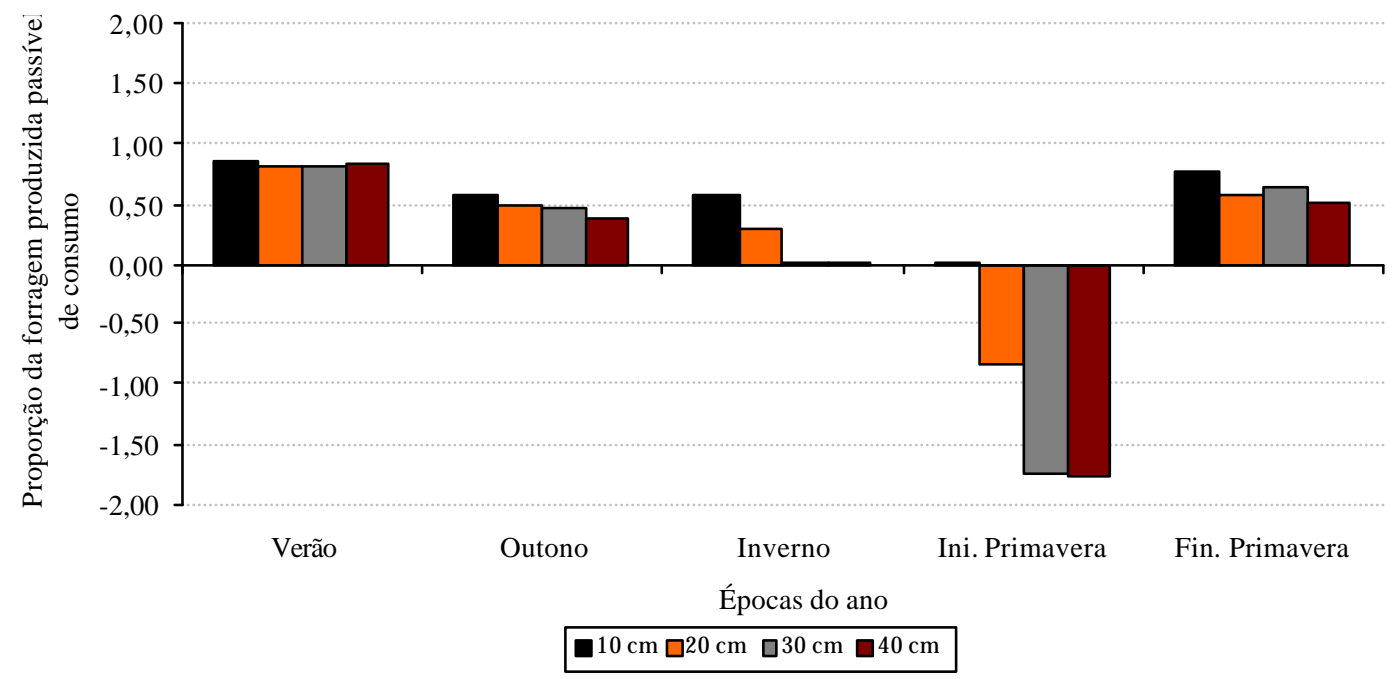

Figura 45 - Proporção da forragem produzida potencialmente disponível para consumo em pastos de capim-Marandu submetidos a quatro alturas de pastejo por meio de lotação contínua

A proporção da forragem produzida disponível para consumo foi semelhante para todas as alturas de dossel apenas durante o período de verão (Figura 45). Durante o outono, inverno, início e final da primavera ela diminuiu com o aumento em altura do dossel. Isso indica que a manutenção de dosséis mais altos só seria viável durante o período mais quente e chuvoso do ano, uma vez que a proporção entre a forragem produzida e senescida foi praticamente igual para todas alturas de dossel nesse período. Por outro lado, durante o início da primavera os valores encontrados foram negativos para alturas superiores a $10 \mathrm{~cm}$, indicando que as taxas de senescência foram maiores que as de crescimento, caracterizando uma situação na qual não seria possível, teoricamente, a remoção de forragem alguma da área para a manutenção de uma dada altura de dossel. Gonçalves (2003) também calculou as eficiências de pastejo em capimMarandu e obteve valores que variaram de 68,7 a $82,3 \%$ para as alturas de 40 e $10 \mathrm{~cm}$, 
respectivamente, entre os meses de Novembro e Janeiro. Esse autor utilizou dados de frequiência e intensidade de desfolhação de perfilhos individuais associados com àqueles de longevidade de folhas para o cálculo das eficiências de utilização. As diferenças nos métodos de estimação poderia ser a responsável pela diferença entre os valores reportados e os obtidos neste experimento. De qualquer maneira, ilustram uma situação verificada na maior parte do ano, em que eficiências de pastejos mais elevadas estiveram consistentemente associadas com a manutenção de alturas mais baixas de dossel.

\subsection{Compensação tamanho/densidade populacional de perfilhos}

\subsubsection{Relação funcional entre massa e densidade populacional de perfilhos}

Os coeficientes angulares da relação funcional (em escala logarítmica) entre massa e densidade populacional de perfilhos foram menores que a proposição teórica de $-3 / 2$, amplamente descrita na literatura e sugerida para relações dessa natureza (Yoda et al., 1963; Kays \& Harper, 1974; Lonsdale \& Watkinson, 1982) (Tabelas 42 e 43). Segundo Sackville-Hamilton et al. (1995), uma reta de inclinação -3/2 seria uma expectativa teórica quando o IAF e a razão área foliar: volume por perfilho (R) permanecessem constantes. Além disso, o modelo matemático proposto por esses autores considera que possíveis variações em densidade aparente dos perfilhos também poderiam explicar as variações na inclinação predita da reta. No entanto, dadas as dificuldades em se estimar a densidade aparente de perfilhos, tem-se assumido valores de densidade constantes ao longo de uma ampla faixa de variação em alturas do dossel, de tal forma que as correções têm sido feitas com base em variações no IAF e em R apenas (Matthew et al., 1995; Sackville-Hamilton et al., 1995; Sbrissia et al., 2001; 2003).

As correções para IAF e $\mathrm{R}$ foram propostas por Matthew et al. (1995) e denominadas $\mathrm{C}_{\mathrm{a}}$ e $\mathrm{C}_{\mathrm{r}}$, respectivamente. Os modelos propostos por esses autores consideram a possibilidade de variações em densidade aparente, que aqui será tratado como um novo coeficiente, $\mathrm{C}_{\mathrm{d}}$. As três correções definem uma correção " $\mathrm{C}$ ", onde $\mathrm{C}=$ 
$\mathrm{C}_{\mathrm{a}}+\mathrm{C}_{\mathrm{r}}+\mathrm{C}_{\mathrm{d}}$, que representa uma mudança vertical hipotética na reta $-3 / 2$. Para explicar $\mathrm{C}_{\mathrm{a}}$, considera-se que aumentos em tamanho dos perfilhos ocorrem com o aumento em altura do dossel. Dessa forma, o IAF do pasto também aumenta. A variação na inclinação da linha de compensação tamanho/densidade populacional de perfilhos em relação ao valor teórico de $-3 / 2$ pode ser definida como sendo o deslocamento da linha de um IAF constante (-3/2) para uma outra linha de IAF também constante só que com um valor de intercepto mais alto. Isso geraria uma nova linha com inclinação maior em relação à reta $-3 / 2$ e a correção seria expressa como o aumento teórico em densidade populacional de perfilhos necessário para alcançar a nova linha de IAF constante ou como uma mudança no intercepto da linha teórica de IAF constante (Matthew et al., 1995). Já $C_{\mathrm{r}}$ poderia ser explicado como variações na forma do perfilho à medida que ocorrem variações em densidade populacional para alturas variáveis de dossel. Assim, se uma grande modificação na forma do perfilho não for acompanhada por um incremento compatível em IAF, a correção $\mathrm{C}_{\mathrm{F}}$ prediria uma inclinação maior que $-3 / 2$, já que a correção C é o resultado da soma de $\mathrm{C}_{\mathrm{a}}, \mathrm{C}_{\mathrm{r}}$ e $\mathrm{C}_{\mathrm{d}}$, sendo que $\mathrm{C}_{\mathrm{r}}$ assume normalmente um valor negativo (Matthew et al., 1995). Já a variação em $\mathrm{C}_{\mathrm{d}}$ pode ser explicada como o resultado de um possível mecanismo segundo o qual os perfilhos compactariam mais biomassa por unidade de volume, o que, em última instância, reduziria a competição por espaço e, conseqüentemente, a captação de recursos. Por outro lado, se a soma de $C_{a}, C_{r}$ e $C_{d}$ for igual a zero, a inclinação da reta seria $-3 / 2$.

Dados com azevém perene mostraram que $\mathrm{C}_{\mathrm{a}}$ possui um valor próximo de $2,0 \mathrm{e}$ $\mathrm{C}_{\mathrm{r}}$ próximo de $-0,2$, indicando que o valor $\mathrm{R}$, por aumentar em pastos mais altos, reduziu a inclinação da reta predita por $C_{a}$ (Matthew et al., 2000). Essas duas correções praticamente explicaram a discrepância entre a inclinação teórica de $-3 / 2$ e o valor realmente observado para os dados coletados e analisados. Dessa forma, Matthew et al. (1995) observaram inclinações para azevém próximas de $-5 / 2$, sendo que algumas observações anteriores a essa (Davies, 1988) também suportaram as conclusões daqueles autores. Num outro experimento, Hernánde z-Garay et al. (1999) verificaram inclinação para azevém perene de $-2,56$, sendo a inclinação predita pelas correções $C_{a}$ e $C_{r}$ de 2,68 , confirmando que as correções foram capazes de explicar, para plantas de clima 
temperado, as diferenças entre as inclinações observadas e a expectativa teórica de $-3 / 2$ $(-1,5)$. Sbrissia et al. (2001, 2003), trabalhando com os capins Coastcross e Tifton-85, também verificaram variações maiores em $C_{a}$ quando comparados com aquelas em $C_{\text {, }}$, sendo que essas correções explicaram os desvios entre a inclinação real e a teórica de -3/2 em Tifton-85 nas diferentes épocas do ano. Para o Coastcross isso só ocorreu para o período de verão.

Os valores de $\mathrm{C}_{\mathrm{a}}, \mathrm{C}_{\mathrm{r}}$ e $\mathrm{C}_{\mathrm{d}}$ para o capim-Marandu foram calculados e mostraramse eficazes em explicar os desvios entre as inclinações obtidas e as expectativas teóricas de $-3 / 2$ durante todos os períodos avaliados (Tabelas 42 e 43). No entanto, as regressões utilizadas para estimar os valores de $C_{a}$ e $C_{r}$ não foram significativas na maior parte das vezes $(\mathrm{P}>0,10)$. Por essa razão, optouse por apresentar os desvios dos coeficientes angulares e considerar a discussão com base nessas limitações. As correções para mudança na forma dos perfilhos $\left(\mathrm{C}_{\mathrm{r}}\right)$ foram estimadas de duas maneiras. Na primeira, assumitrse uma densidade aparente constante dos perfilhos $\left(950 \mathrm{~kg} . \mathrm{m}^{-3}\right)$ e os volumes correspondentes estimados. Nesse caso, como a densidade era constante foi gerado um novo fator de correção $\left(\mathrm{C}_{\mathrm{d}}\right)$ usando os dados de densidade efetivamente medidos. Durante o período de verão não foi possível calcular essa última correção porque as medições de volume não foram consistentes (seção 3.2.4.4.3). De todas as correções, $C_{d}$ foi a menor delas, indicando que as variações em densidade foram pequenas e pouco modificaram os valores preditos por $C_{a}$ e $C_{r}$ (Tabela 42). Além disso, $C_{a}$ foi a maior correção em todas as avaliações, indicando que variações em IAF foram o principal determinante dos ajustes nas retas de compensação. Apesar disso, durante o início da primavera, os valores de $\mathrm{C}_{\mathrm{a}}$ e $\mathrm{C}_{\mathrm{r}}$ foram muito próximos, indicando que devem ter ocorrido mudanças na forma dos perfilhos provavelmente como uma adaptação às condições de ambiente desfavoráveis naquela época do ano. Na outra forma de cálculo, $\mathrm{C}_{\mathrm{r}}$ foi calculado a partir dos valores de volume efetivamente medidos (Tabela 43). Nesse caso, não foram calculadas as variações em $\mathrm{C}_{\mathrm{d}}$, uma vez que as variações em densidade já estariam sendo consideradas por variações conjuntas na massa e volume dos perfilhos. Como resultado, as duas correções $\left(\mathrm{C}_{\mathrm{a}}\right.$ e $\left.\mathrm{C}_{\mathrm{r}}\right)$ foram eficazes em predizer a inclinação da reta efetivamente obtida por meio das regressões entre densidade populacional e massa 
por perfilho, indicando que em situações onde for possível a medição do volume dos perfilhos não é necessária a introdução de um fator de correção para densidade aparente. Já para os casos onde a estimativa do volume for baseada em densidade aparente constante, deve-se atentar para o fato de que possíveis discrepâncias entre os coeficientes angulares observados (inclinações das retas) e aqueles calculados podem advir de possíveis variações em densidade aparente, apesar de que esse parece representar um efeito menor.

Ao longo dos períodos de avaliação as inclinações das retas de compensação foram diminuindo a partir do verão (Tabela 42 e Figura 46), voltando a aumentar apenas no final da primavera. Essa redução em inclinação significa que conforme as estações avançaram, aumentos em massa resultaram em reduções proporcionalmente maiores no número de perfilhos, principalmente nos pastos mantidos a 30 e $40 \mathrm{~cm}$ (Figura 46).

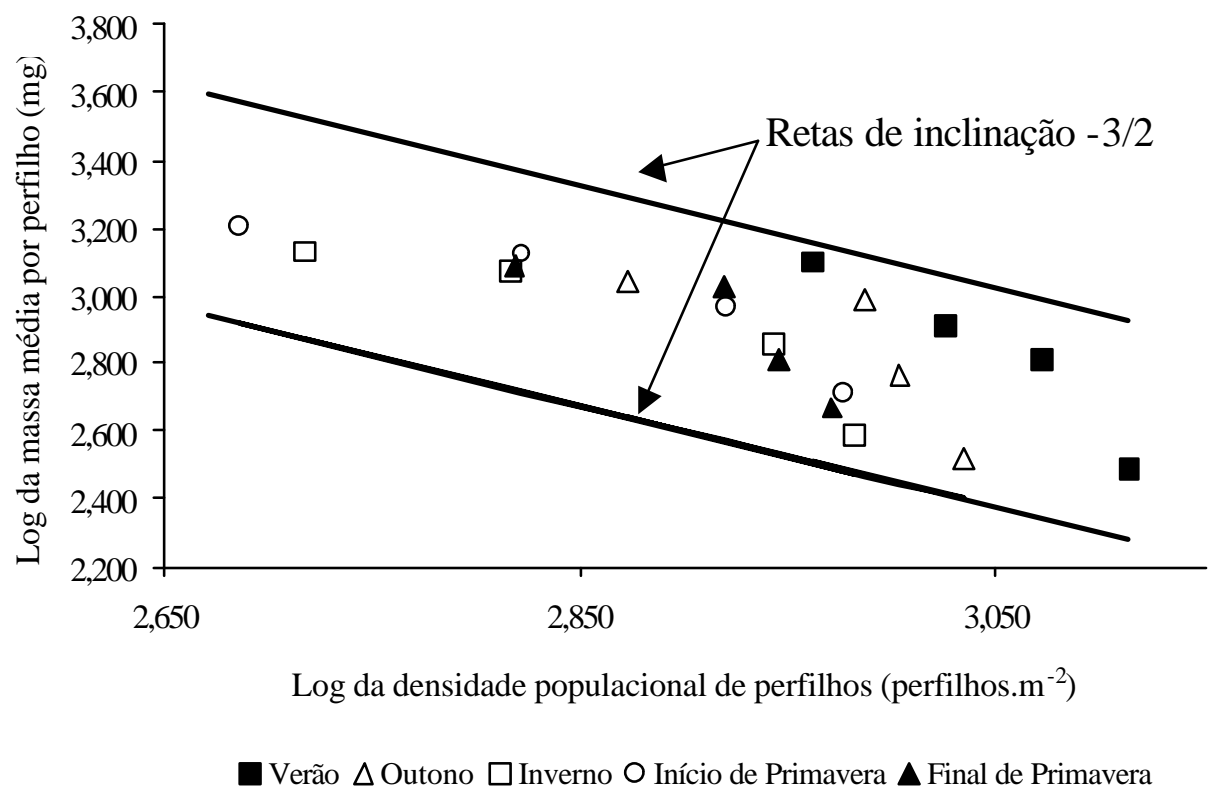

Figura 46 - Coordenadas x/y do log da densidade populacional e do log da massa média por perfilho em pastos de capim-Marandu em diferentes épocas do ano

Interessante observar que a segmentação dos coeficientes angulares entre as alturas de dossel estudadas (Tabela 44) indica que foi apenas durante o verão que 
aumentos em altura do dossel até $40 \mathrm{~cm}$ não provocaram prejuízos em densidade populacional associados com a massa de perfilhos. Durante as épocas de inverno e início da primavera as inclinações entre as alturas de $20-30 \mathrm{~cm}$ foram próximas de $-3 / 2(-1,5)$ indicando, segundo a teoria proposta por Sackville-Hamilton et al. (1995), que o IAF do dossel tende a se manter constante a partir de $20 \mathrm{~cm}$ de altura, fato corroborado pelas avaliações de IAF (Tabela 30). Além disso, exceção feita ao período de verão, durante todas as outras épocas do ano não houve vantagens em se aumentar a altura do dossel além de $30 \mathrm{~cm}$, uma vez que as inclinações foram menores que -1, indicando que a perda de perfilhos foi proporcionalmente maior que o incremento médio em massa média por perfilho. O diagrama multifásico teorizado por Matthew et al. (1995) indica que inclinações próximas de -1 representariam valores constantes de massa de forragem no dossel (condição clímax). O produto entre os valores de DPP (Tabela 17) e os de massa dos perfilhos (Tabela 23) indica reduções na massa de forragem a partir da altura de 30 cm, comprovando a conceituação teórica proposta por Matthew et al. (1995). Dessa forma, não há vantagem em se manter os pastos em alturas superiores a $30 \mathrm{~cm}$ em termos de produção de forragem durante a maior parte do ano (exceção feita ao verão), sendo que durante os períodos de inverno e início de primavera esse valor passaria a ser $20 \mathrm{~cm}$, evidenciando novamente que a otimização da produção em pastos de capimMarandu se daria por meio de ajustes sazonais na altura do dossel.

Tabela 44. Coeficiente angulares das relações entre o log da densidade populacional de perfilhos e a massa média por perfilho.

\begin{tabular}{cccc}
\hline Época do ano & \multicolumn{3}{c}{ Variações nas alturas } \\
\hline & $\Delta_{10-20}$ & $\Delta_{20-30}$ & $\Delta_{30-40}$ \\
Verão & $-7,44$ & $-2,34$ & $-2,86$ \\
Outono & $-8,45$ & $-12,67$ & $-0,46$ \\
Inverno & $-7,12$ & $-1,70$ & $-0,58$ \\
Início de Primavera & $-4,42$ & $-1,66$ & $-0,56$ \\
Final de Primavera & $-5,46$ & $-8,20$ & $-0,63$ \\
\hline
\end{tabular}


Recentemente, uma série de trabalhos tem questionado a validade de uma relação -3/2 entre densidade populacional e massa de plantas (ou perfilhos) e sugerido que essa relação deva ser de -4/3 (West et al., 1997, West et al., 1999, Enquist et al., 1999, Niklas et al., 2003). A polêmica em torno da inclinação de $-3 / 2$ verificada por Yoda et al. (1963) é histórica no meio científico (Sackville-Hamilton et al., 1995). A proposições mais recentes estão basicamente associadas com relações alométricas entre diferentes processos metabólicos nas plantas. Assim, West et al. (1999) verificaram que diversos processos relacionam-se com a massa de um indivíduo segundo a quarta potência (i.e. taxa metabólica massa ${ }^{3 / 4}$, ou ainda que o comprimento massa ${ }^{1 / 4}$ ). A partir dessas observações, amparadas por descobertas de diversos outros autores, West et al. (1997) propuseram que relações dessa natureza deveriam seguir inclinações de $-4 / 3$. No entanto, essas descobertas não são consensuais. Pretzsch (2002) reafirmou as observações originais de Yoda et al. (1963) e propôs a manutenção de uma relação de -3/2. Sua justificativa foi basicamente amparada em relações alométricas inquestionáveis de figuras geométricas simples. Na verdade, as diferenças entre as inclinações $(-0,17)$ é pequena e existe uma série de fatores que podem originar inclinações diferentes para um certo conjunto de dados (algoritmos de regressões utilizados, desvios dos coeficientes angulares, natureza dos dados, entre outros), de tal forma que é difícil estabelecer com clareza a maneira com que as plantas respondem a esses mecanismos. Por exemplo, na figura 2 de Niklas \& Enquist (2001), onde são estabelecidas relações alométricas entre taxa de crescimento e comprimento da planta em relação à sua massa, claramente existem pontos que estariam, no mínimo, influenciando as inclinações e que sua retirada ou não do conjunto de dados analisados dependeria quase que exclusivamente de um certo grau de subjetivismo, ou ainda, do uso de programas estatísticos que estão distantes de ser de uso consensual entre pesquisadores.

Quando consideradas as inclinações originalmente estimadas e subtraídas as correções $\mathrm{C}_{\mathrm{a}}$ e $\mathrm{C}_{\mathrm{r}}$, os valores observados neste experimento aproximam-se de inclinações de -3/2 (Tabela 45). No entanto, os desvios para as correções calculadas são altos (Tabela 43), tornando difícil definir se uma reta de IAF constante pode ser definida em termos de inclinação de $-3 / 2$ ou $-4 / 3$. 
Tabela 45. Inclinação estimada, as correções para IAF e forma do perfilho e inclinação hipotética de uma reta de IAF constante.

\begin{tabular}{ccccc}
\hline Época do ano & $\begin{array}{c}\text { Inclinação } \\
\text { estimada }\end{array}$ & $\mathrm{C}_{\mathrm{a}}$ & $\mathrm{C}_{\mathrm{r}}$ & $\begin{array}{c}\text { Inclinação } \\
\text { predita de IAF } \\
\text { constante }\end{array}$ \\
\hline Verão & $-3,92$ & 3,67 & 1,19 & 1,44 \\
Outono & $-3,41$ & 2,84 & 0,91 & 1,48 \\
Inverno & $-2,05$ & 1,12 & 0,65 & 1,58 \\
Ini. Primavera & $-1,70$ & 0,76 & 0,52 & 1,46 \\
Fin. Primavera & $-2,88$ & 3,18 & 1,73 & 1,43 \\
\hline
\end{tabular}

\subsubsection{Implicações agronômicas}

Matthew et al. (1995) sugeriram que a distância de qualquer ponto, relacionando massa e densidade populacional de perfilhos, para a linha teórica de inclinação $-3 / 2$ poderia ter valor como um índice de produtividade do pasto. Como mostrado por Sackville-Hamilton et al. (1995), a reta $-3 / 2$ define uma situação onde o IAF é constante. Dessa maneira, quanto maior a distância entre os pontos observados e uma dada reta $-3 / 2$, maior seria o IAF do dossel e, consequentemente, maior sua capacidade de acúmulo de forragem. Essa hipótese foi confirmada para plantas de clima temperado a partir de experimentos em micro-relvados (Hernández-Garay et al., 1999) e em situações de campo (Hernández-Garay et al., 1997; Bahmani et al., 1998) e recentemente comprovada para cultivares de Cynodon por Sbrissia et al. (2001, 2003). Como pode ser observado na Figura 47 e na Tabela 46, as correlações entre distância e IAF não foram significativas apenas para os períodos de inverno e início da primavera, indicando que a distância entre os pontos obtidos (resultado da combinação de massa e densidade populacional de perfilhos) e a reta $-3 / 2$ poderia ter valor para predizer, pelo menos durante a época de maior crescimento, o IAF de pastos de capim-Marandu, variável essa 
considerada fundamental na compreensão dos processos de acúmulo de forragem (Lemaire \& Agnusdei, 2000) e manejo da desfolhação (Lemaire \& Chapman, 1996).

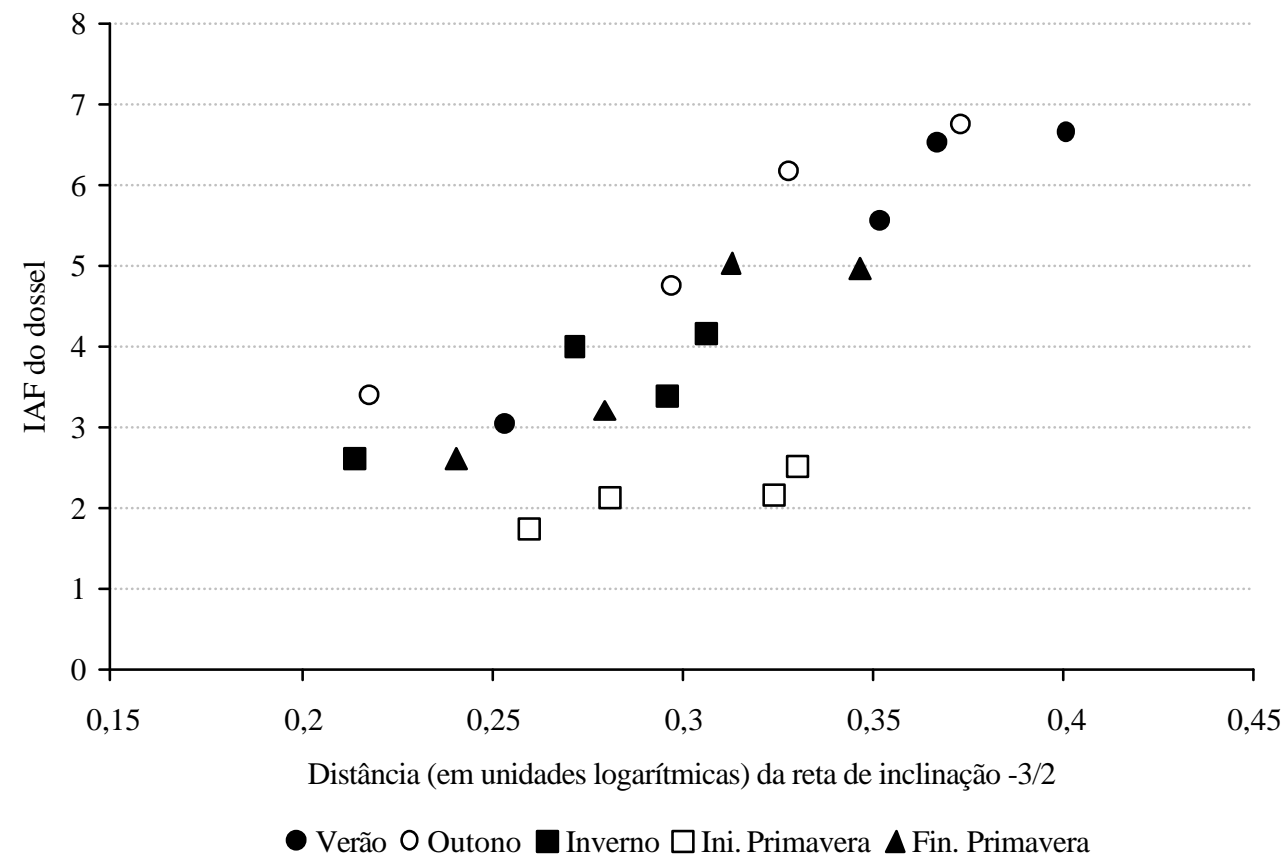

Figura 47 - Distância (em unidades logarítmicas) das coordenadas x/y da relação entre densidade populacional de perfilhos e massa e uma reta de inclinação $-3 / 2$

Tabela 46. Correlação (r) entre a distância de pontos de coordenadas x/y (em unidades logarítmicas) à reta de inclinação teórica -3/2 e o IAF atual do dossel.

\begin{tabular}{|c|c|c|c|c|c|c|c|c|c|c|}
\hline \multirow{3}{*}{$\begin{array}{c}\text { Epoca do } \\
\text { ano }\end{array}$} & \multicolumn{8}{|c|}{ Altura do pasto $(\mathrm{cm})$} & \multirow[b]{3}{*}{$\mathrm{r}$} & \multirow[b]{3}{*}{$\mathrm{P}$} \\
\hline & \multicolumn{2}{|c|}{10} & \multicolumn{2}{|c|}{20} & \multicolumn{2}{|c|}{30} & \multicolumn{2}{|c|}{40} & & \\
\hline & Dist. & IAF & Dist. & IAF & Dist. & IAF & Dist. & IAF & & \\
\hline Verão & 0,25 & 3,0 & 0,35 & 5,5 & 0,37 & 6,5 & 0,40 & 6,7 & 0,99 & 0,008 \\
\hline Outono & 0,28 & 3,4 & 0,30 & 4,7 & 0,37 & 6,7 & 0,33 & 6,1 & 0,98 & 0,010 \\
\hline Inverno & 0,21 & 2,6 & 0,30 & 3,41 & 0,31 & 4,2 & 0,27 & 4,0 & 0,87 & 0,132 \\
\hline Ini. Prim. & 0,26 & 1,7 & 0,32 & 2,2 & 0,33 & 2,5 & 0,28 & 2,1 & 0,87 & 0,123 \\
\hline Fin. Prim. & 0,24 & 2,6 & 0,28 & 3,2 & 0,34 & 5,0 & 0,3 & 5,0 & 0,94 & 0,054 \\
\hline
\end{tabular}




\subsection{Análise multivariada dos dados}

Apesar de ser uma técnica relativamente antiga (Jollife, 1986), a análise de componentes principais ( $\mathrm{ACP}$ ) (assim como outras técnicas multivariadas) não tem sido usada com freqüência na interpretação de dados de pesquisas com plantas forrageiras. $\mathrm{Na}$ verdade, apesar de antiga, apenas recentemente, com o desenvolvimento de processadores mais rápidos de computador, é que análises multivariadas puderam ser usadas mais rotineiramente e incorporadas nas rotinas de análises de dados (Matthew et al., 1994). Brevemente, a análise de componentes principais gera novas variáveis, que são funções lineares das variáveis originais (Jollife, 1986). Nesse sentido, a ACP maximiza a proporção da variância do conjunto de dados expresso por sucessivos componentes principais (CPs) que não são correlacionados entre si. A principal utilidade da ACP é reduzir a dimensionalidade do conjunto de dados retendo tanta informação quanto possível num menor número de CPs. Assim, o primeiro componente principal (CP) é a combinação das variáveis que explica a maior proporção da variação total dos dados. O segundo $\mathrm{CP}$ define a maior variação seguinte e assim sucessivamente. A quantidade de CPs geradas é igual ao número de variáveis analisadas sendo que apenas os primeiros CPs podem responder por até $80 \%$ da variação do conjunto de dados. Uma limitação da ACP é que correlações não lineares entre as variáveis não são consideradas, uma vez que a técnica é, por definição, linear.

Para a primeira análise realizada, em que foram consideradas a DPP, MP, IAF, R, FH, TAP e TSP, os resultados indicaram que $84,8 \%$ da variação no conjunto de dados poderia ser explicada por apenas três CPs. A escolha do número de CPs a ser utilizado depende do pesquisador. No entanto, Jolliffe (1986) sugeriu que eigenvalue menores que 1 poderiam ser descartados ou ainda, dependendo do pesquisador e da natureza dos dados, poderia se escolher componentes que explicassem, por exemplo, $60 \%$ da variação nos dados. Além disso, esse mesmo autor sugere que os as correlações entre os componentes principais e as variáveis originais inferiores a 0,25 fossem descartadas. $\mathrm{O}$

primeiro CP explicou $39 \%$ da variação total dos dados, e relacionou basicamente aspectos do mecanismo de compensação tamanho/densidade populacional (Tabela 47). 
Além disso, nesse primeiro $\mathrm{CP}$ a densidade populacional de perfilhos (DPP) esteve diretamente associada com a taxa de aparecimento de perfilhos (TAP), ou seja, uma redução no número de perfilhos implicou diretamente numa redução na TAP e em um aumento na taxa de sobrevivência de perfilhos (TSP). Importante comentar que na ACP não é levado em consideração o efeito isolado de blocos, tratamentos ou tempo.

Tabela 47. Análise de componentes principais: eigenvalue, proporção da variância explicada por cada componente, acumulada e correlações entre os componentes e as variáveis originais

\begin{tabular}{llllllll}
\hline Eigenvalue & 2,732 & 2,041 & 1,162 & 0,436 & 0,393 & 0,180 & 0,055 \\
Proporção & 0,39 & 0,292 & 0,166 & 0,062 & 0,056 & 0,026 & 0,008 \\
Acumulado & 0,39 & 0,682 & 0,848 & 0,910 & 0,966 & 0,992 & 1,000 \\
\hline Variável $^{*}$ & $\mathrm{CP}_{1}$ & $\mathrm{CP}_{2}$ & $\mathrm{CP}_{3}$ & $\mathrm{CP}_{4}$ & $\mathrm{CP}_{5}$ & $\mathrm{CP}_{6}$ & $\mathrm{CP}_{7}$ \\
& & & & & & & \\
DPP & $-0,545$ & $-0,004$ & 0,023 & $-0,407$ & $-0,499$ & 0,104 & 0,526 \\
MP & 0,497 & $-0,315$ & $-0,176$ & 0,058 & 0,020 & 0,641 & 0,457 \\
IAF & $-0,108$ & $-0,645$ & 0,184 & $-0,161$ & $-0,305$ & 0,263 & $-0,592$ \\
R & 0,022 & $-0,518$ & 0,572 & 0,075 & 0,274 & $-0,410$ & 0,394 \\
FH & $-0,204$ & 0,365 & 0,669 & 0,326 & 0,052 & 0,517 & $-0,038$ \\
TAP & $-0,408$ & $-0,254$ & $-0,336$ & 0,794 & $-0,132$ & $-0,029$ & 0,086 \\
TSP & 0,486 & 0,137 & 0,219 & 0,249 & $-0,750$ & $-0,269$ & 0,029 \\
\hline
\end{tabular}

$\mathrm{DPP}=$ densidade populacional de perfilhos, MP $=$ massa por perfilho, IAF $=$ índice de área foliar, $\mathrm{R}=$ razão área foliar: volume, $\mathrm{FH}=$ relação folha: haste, TAP=Taxa de aparecimento de perfilhos $\mathrm{e}$ TSP=Taxa de sobrevivência de perfilhos.

Já no segundo CP, que explicou $29,2 \%$ na variação dos dados, é mostrada a correlação positiva entre a MP, IAF e R e uma correlação negativa entre R e FH. Essa última correlação evidencia a diferença nas duas formas de se avaliar a relação entre folha e haste do pasto. As razões para essa discrepância foram devidamente discutidas no item 5.4. Pode parecer paradoxal, mas no terceiro CP foi detectada uma correlação positiva entre R e FH. No entanto, esse efeito está associado basicamente aos efeitos de época, uma vez que aumentos sazonais em R implicaram em aumentos na relação folha: haste. O significado implícito nessa correlação está associado à pequena variação no comprimento das hastes ao longo do ano (Tabela 16), ou seja, o principal mecanismo 
para o ajuste na forma do perfilho entre as estações esteve relacionado com a sua capacidade em se adaptar às condições de ambiente por meio de aumentos ou reduções em sua área foliar. Como o comprimento das hastes variou pouco entre as épocas do ano, é natural que aumentos ou reduções em área foliar por perfilho implicassem em variações equivalentes em $\mathrm{R}$ e na relação folha: haste. Apesar do quarto $\mathrm{CP}$ representar apenas $6,2 \%$ da variação dos dados, ele mostra uma informação interessante: reduções em densidade populacional de perfilhos podem resultar em incrementos nas taxas de aparecimento e aumentos na relação FH. Como pode ser observado na Tabela 19, altas taxas de aparecimento foram registradas em dosséis mantidos a $40 \mathrm{~cm}$ durante as épocas de verão e outono. Assim, reduções em densidade populacional resultaram em aumentos na taxa de aparecimento de perfilhos pelos efeitos conjugados de: (1) estímulo ao perfilhamento em períodos mais quentes e de maior incidência de luz, (2) períodos de florescimento mais intenso (Tabela 18) e (3) efeito de manipulação dos anéis de perfilhamento.

Na segunda análise (DPP, LF, AFE, TAlF e TSF) ficou evidenciada no primeiro CP $(54,7 \%$ da variação total) a relação inversa entre a longevidade de folhas e área foliar específica (Tabela 48).

Tabela 48. Análise de componentes principais: eigenvalue, proporção da variância explicada por cada componente, acumulada e correlações entre os componentes e as variáveis originais

\begin{tabular}{llllll} 
Eigenvalue & 2,737 & 1,484 & 0,375 & 0,244 & 0,158 \\
Proporção & 0,547 & 0,297 & 0,075 & 0,049 & 0,032 \\
Acumulado & 0,547 & 0,844 & 0,919 & 0,968 & 1,000 \\
\hline Variável & $\mathrm{CP}_{1}$ & $\mathrm{CP}_{2}$ & $\mathrm{CP}_{3}$ & $\mathrm{CP}_{4}$ & $\mathrm{CP}_{5}$ \\
& & & & & \\
DPP & $-0,447$ & 0,413 & $-0,604$ & $-0,490$ & 0,156 \\
LONG & 0,558 & 0,070 & $-0,022$ & $-0,603$ & $-0,565$ \\
AFE & $-0,523$ & $-0,096$ & 0,697 & $-0,479$ & $-0,045$ \\
TAF & $-0,436$ & $-0,497$ & $-0,322$ & 0,160 & $-0,657$ \\
TSF & 0,160 & 0,754 & $-0,210$ & $-0,374$ & 0,471 \\
\hline
\end{tabular}


Como discutido no item 5.2, a relação inversa entre essas características poderia estar relacionada com a economia de nutrientes pela planta em épocas de adversidades climáticas. Já no segundo CP (29,7\% da variação total), foi detectado a relação inversa entre a densidade populacional de perfilhos e taxa de alongamento e senescência de folhas, indicando que aumentos nas taxas de alongamento estão necessariamente associados com aumentos nas taxas de senescência e menor população de perfilhos, condição característica de pastos mantidos mais altos.

\subsection{Considerações finais}

Há fortes evidências de que pastos de capim-Marandu tenham exigências sazonais no que diz respeito ao manejo do pastejo. Os valores de acúmulo líquido de forragem indicaram que a otimização da produção (balanço entre crescimento e senescência) ocorreu entre as alturas de 20 e $30 \mathrm{~cm}$, durante o período de verão. No entanto, parece que durante o período de inverno e início de primavera os pastos deveriam ser rebaixados para valores intermediários entre 10 e $20 \mathrm{~cm}$, muito provavelmente $15 \mathrm{~cm}$. Essa hipótese é evidenciada, primeiramente, pela inversão nas alturas onde ocorreu a máxima taxa de acúmulo líquido, ou seja, a partir do outono os acúmulos líquidos começaram a ser máximos entre as alturas de 10 e $20 \mathrm{~cm}$. Além disso, a combinação entre densidade populacional de perfilhos e massa média por perfilho mostrou que, durante as épocas mais frias e secas do ano, aumentos em altura do dossel implicaram numa redução proporcionalmente maior no número de perfilhos quando comparada com a variação em massa dos mesmos, fazendo com que a massa de forragem não aumentasse a partir da altura de $30 \mathrm{~cm}$. Após o período de déficit hídrico, os pastos apresentaram, no final da primavera, um rápido crescimento. Dessa forma, a partir de outubro poderia se permitir que os pastos fossem mantidos novamente entre 20 e $30 \mathrm{~cm}$ até o final do verão. Uma possível crítica a tal hipótese seria a de que pastos mantidos mais altos ainda assim apresentaram valores de IAF maiores que aqueles de pastos mantidos mais baixos durante quase todo "período seco", sendo que, apesar de 
não ter havido crescimento compatível com esse maior IAF, os pastos poderiam estar acumulando reservas orgânicas para uma rebrotação mais rápida no final da primavera. Sem dúvida, tal possibilidade existe, e análises dos teores de compostos de reserva durante todo o período seco deverão vir a dirimí-la. No entanto, a grande redução nos valores de densidade populacional de perfilhos para pastos mantidos mais altos sugere que parte das reservas deveria também ser direcionada para reconstituição da população de perfilhos. Dessa forma, novamente parece que a redução em altura do dossel continuaria sendo uma alternativa mais viável, simplesmente pelo aumento na eficiência de utilização da já escassa forragem produzida no inverno e pela manutenção de valores mais altos de densidade populacional de perfilhos .

Apesar dos resultados deste experimento terem sido bastante consistentes e terem mostrado que a altura do dossel pode ser uma ferramenta poderosa no manejo do pastejo do capim-Marandu, Lemaire \& Agnusdei (2000) afirmaram que a clássica relação linear entre taxa de senescência e altura do dossel (Bircham \& Hodgson, 1983), repetidamente obtida em diversas condições, deve ser interpretada não como um resultado da altura do pasto per se, mas como uma diferença nas taxas de lotação necessárias para se manter o dossel numa dada altura. Pode parecer uma questão meramente semântica mas, no entanto, essa observação possui implicações importantes no delineamento de experimentos de pastejo e na aplicação dos dados obtidos. Por exemplo, Lemaire \& Agnusdei (2000) comentaram que a correlação entre altura do dossel, taxa de lotação e fluxo de tecidos em comunidades de plantas, geralmente observadas em experimentos do tipo "put and take", pode ser quebrada quando ocorrem flutuações climáticas ou espécies com características de crescimento diferentes são consideradas. Dessa forma, enquanto altura e IAF do dossel são características estruturais relevantes na determinação das tradicionais respostas assintóticas de produção de forragem, eles não são determinantes diretos das taxas de senescência observadas em pastos mantidos em lotação contínua, uma vez que existe uma assincronia entre a produção de novos tecidos e a senescência foliar.

Assim, do ponto de vista de manejo, a indicação de uma altura de dossel "ideal" deve ser interpretada dentro das restrições de cada propriedade. Por exe mplo, atividades 
de manejo (adubação, irrigação etc.) que possam acelerar o crescimento dos pastos e aumentar a capacidade de suporte das pastagens, induzem a um aumento na eficiência de utilização de tal forma que, dependendo do manejo empregado, diferentes alturas de dossel podem apresentar taxas de utilização semelhantes. Dessa forma, na ausência de qualquer alternativa que aumente a produção de forragem, seria mais desejável manter o capim-Marandu em alturas mais baixas a fim de minimizar as perdas por senescência e aumentar a eficiência de colheita. Já para produtores mais tecnificados, a oportunidade de melhor colheita pode ser uma combinação entre uma altura mais alta (maior taxa de crescimento) associada com aumentos correspondentes em taxa de lotação, o que também manteria a eficiência de colheita em níveis elevados. Estratégicas específicas de manejo do pastejo vão depender, portanto, da disponibilidade de recursos e dos propósitos de cada produtor, sendo que o capim-Marandu oferece plasticidade e uma faixa ampla de utilização que assegura a manutenção de sua produtividade.

Os avanços recentes na pesquisa com pastagens têm mostrado que idiossincrasias no que diz respeito ao manejo do pastejo têm perdido espaço para resultados obtidos a partir de experimentação científica objetiva e perfeitamente aplicáveis no dia a dia. No que diz respeito à pesquisa e ao planejamento de experimentos com plantas forrageiras, Sbrissia \& Da Silva (2001) comentaram que a abordagem reducionista da experimentação implica numa reformulação de paradigmas, sendo que essa concepção implica numa discussão criteriosa dos objetivos da pesquisa para que se possa distinguir claramente se o objeto de estudo é relevante ou apenas alvo de curiosidade acadêmica. Além disso, muito mais difícil é determinar se o resultado obtido é consistente e genuíno ou está apenas evidenciando deficiências de planejamento da pesquisa e de interpretação dos dados. 


\section{CONCLUSÕES}

Com base nos resultados deste experimento, as seguintes conclusões foram elaboradas:

- O capim-Marandu exige variações sazonais em seu manejo, sendo que durante o período de verão e final de primavera a altura do dossel deve ser mantida de 20-30 cm e durante o outono, inverno e início da primavera entre $10-20 \mathrm{~cm}$.

- Avaliações isoladas de densidade populacional de perfilhos não devem ser interpretadas como um indicativo de vigor ou persistência de pastos.

- O volume de perfilhos pode ser medido de maneira acurada e sua consideração em análises de crescimento deve trazer novas concepções para pesquisa no diz respeito ocupação espacial e competição de plantas em ecossistemas.

- Soma térmica (graus-dia) e unidade fototérmica apresentam correlações baixas com características morfogênicas quando existem limitações climáticas, principalmente água. 


\section{REFERÊNCIAS BIBLIOGRÁFICAS}

AERTS, R. The advantages of being evergreen. Trends in Ecology and Evolution v.10, p.402-407, 1995.

ANDRADE, F.M.E. Produção de forragem e valor alimentício do capim-Marandu submetido a regimes de lotação contínua por bovinos de corte. Piracicaba, 2004. 125p. (Mestrado) - Escola Superior de Agricultura "Luiz de Queiroz", Universidade de São Paulo.

ARREDONDO, J.T.; SCHNYDER, H. Components of leaf elongation rate and their relationship to specific leaf area in contrasting grasses. New Phytologist, v.158, n.2, p.305-314, 2003.

ASPINALL, D. The control of tillering in the barley plant. I. The pattern of tillering and its relation to nutrient supply. Australian Journal of Biological Science, v.14, p.493-505, 1961.

BADILA, P.; LAUZAC, M.; PAULET, P. The characteristics of light in floral induction in vitro of Cichorium intybus. The possible role of phytochrome. Physiologia Plantarum, v.65, p.305-309, 1985. 
BAHMANI, I.; THOM, ER.; MATTHEW, C.; HOOPER, R.J.; LEMAIRE, G. Tiller dynamics of perennial ryegrass cultivars derived from different New Zealand ecotypes: effects of cultivar, season, nitrogen fertiliser, and irrigation. Australian Journal of Agricultural Research, v.54, n.8, p.803-817, 2003.

BARNES, C.; BUGBEE, B. Morphological responses of wheat to blue light. Journal of Plant Physiology, v.139, p.339-342, 1992.

BIRCHAM, J.S.; HODGSON, J. The influence of sward condition on rates of herbage growth and senescence in mixed swards under continuous stocking management. Grass and Forage Science, v.38, n.4, p.323-331, 1983.

BLACK, C.K.; CHU, A.C.P. Searching for an alternative way to manage prairie grass. IN: NEW ZEALAND GRASSLAND ASSOCIATION, 50, 1989. Proceedings, p.219-223.

BONHOMME, R. Bases and limits to using 'degree.day' units. European Journal of Agronomy, v.13, p.1-10, 2000.

BRADSHAW, A.D. Evolutionary significance of phenotypic plasticity in plants. Advances in Genetics, v.13, p.115-155, 1965

BRASIL. Ministério da Agricultura. Serviço Nacional de Pesquisa Agronômica. Comissão de Solos. Levantamento de reconhecimento dos solos do Estado de São Paulo. Rio de Janeiro, 1960. 634p. (Boletim,12).

BRISKE, D.D. Developmental morphology and physiology of grasses. In: HEITSCHMIDT, R.K.; STUTH, J.W. (Ed.) Grazing management: an ecological perspective. Portland: Timber Press, 1991.p. 85-108. 
BRISKE, D. D. Strategies of plant survival in grazed systems: A functional interpretation. In: HODGSON, J.; ILLIUS, A.W. (Ed.). The Ecology and Management of Grazing Systems . London: CAB International, 1996. cap. 2, p.3767.

BROUGHAM, R. W. Effects of intensity of defoliation on regrowth of pasture. Australian Journal of Agriculture Research, v. 7, p. 377-387, 1956.

BUTTLER, J.L.; BRISKE, D.D. Population structure and tiller demography of the buchgrass Schizachyrium scoparium in response to herbivory. Oikos, v.51, p.306$312,1988$.

CABLE, D.R. Partial defoliation stimulates growth of Arizona cottontop. Journal of Range Management, v.35, p.591-593, 1982.

CAPRA, F. The turning point : science, society and the rising culture. Toronto: Bantam Publisher. 1983. 464p.

CARNEVALLI, R.A. Dinâmica da rebrotação de pastos de capim-Mombaça submetidos a regimes de desfolhação intermitente. Piracicaba, 2003. 136p. Tese (Doutorado) - Escola Superior de Agricultura “Luiz de Queiroz", Universidade de São Paulo.

CARNEVALLI, R.A.; Da SILVA, S.C. Avaliação de algumas características agronômicas e ecológicas de plantas da espécie Cynodon dactylon cv. Coastcross para fins de validação de técnicas para ensaios de pastejo com plantas forrageiras. Scientia Agricola, v.56, p.489-499, 1999. 
CARVALHO, C.A.B.; DA SILVA, S.C.; SBRISSIA, A.F.; PINTO, L.F.M.; CARNEVALli, R.A.; FAGUNDES, J.L.; PEDREIRA, C.G.S. Demografia do perfilhamento e acúmulo de matéria seca em capim Tifton- 85 submetido a pastejo. Scientia Agricola, v. 57, n. 4, p. 591-600, 2000a.

CARVALHO, C.A.B.; DA SILVA, S.C.; CARNEVALli, R.A.; SBRISSIA, A.F.; PINTO, L.F.M.; FAGUNDES, J.L.; PEDREIRA, C.G.S. Perfilhamento e acúmulo de forragem em pastagens de Florakirk manejadas em quatro alturas de pasto. Boletim de Indústria Animal, v.57, n.1, p.39-51, 2000 b.

CARVALHO, C.A.B.; DA SILVA, S.C.; SBRISSIA, A.F.; PINTO, L.F.M.; CARNEVALLI, R.A.; FAGUNDES, J.L.; PEDREIRA, C.G.S. Demografia do perfilhamento e acúmulo de matéria seca em coastcross submetido a pastejo. Pesquisa Agropecuária Brasileira, v.36, n.3, p.567-575, 2001.

CASAL, J.J.; DEREGIB US, V.A.; SANCHEZ, R.A. Variations in tiller dynamics and morphology in lolium multiflorum lam vegetative and reproductive plants as affected by differences in red far-red irradiation. Annals of Botany, v.56, n.4, p.553-559, 1985.

CASPER, B. B.; FORSETH, I.N.; KEMPENICH, H.; SELTZER, S.; XAVIER, K. Drought prolongs leaf life span in the herbaceous desert perennial Cryptantha flava. Functional Ecology, v.15, n.6, p.740-747, 2001.

CHAPMAN, D. F.; LEMAIRE, G. Morphogenic and structural determinants of plant regrowth after defoliation. In: BAKER, M. J. (Ed.). Grasslands for our world. Wellington: SIR, 1993. cap. 3. p. 55-64. 
COOPER, J. P.; WILSON, D. Variation in photosynthetic rate in Lolium. In: INTERNATIONAL GRASSLAND CONGRESS, 11, Surfers Paradise, 1970. Proceedings. Santa Lucia: University of Queensland Press, 1970. p.522-527.

COTTIGNIES, A.; JENNANE, A. Water content, water potential, and transition from the noncycling to the cycling state in the pea cotiledonary bud. Journal of Plant Physiology, v.132, p.1-4, 1988.

CRONQUIST, A. The evolution and classification of flowering plants. New York: The New York Botanical Garden, 1988. 555p.

DALE, J.E. Some effects of temperature and irradiance on growth of the first four leaves of wheat, triticum aestivum. Annals of Botany, v.50, p.851-858, 1982.

DA SILVA, S. C.; PEDREIRA, C. G. S. Princípios de ecologia aplicados ao manejo de pastagem. In: SIMPÓSIO SOBRE ECOSSISTEMAS DE PASTAGENS, 3., Jaboticabal, 1997. Anais. Jaboticabal : FUNEP, 1997, p. 1-62.

DAVIES, A. Leaf tissue remaining after cutting and regrowth in perennial ryegrass. Journal of Agricultural Science, v.82, p.165-172, 1974.

DAVIES, A. Structure of the grass swards. INTERNATIONAL MEETING ON ANIMAL PRODUCTION FROM TEMPERATE GRASSLAND. Dublin, 1977. Proceedings, Dublin: An Foras Taluntais, 1977. p.36-44.

DAVIES, A. The regrowth of grass swards. In: JONES, M.B.; LAZENBY, A. (Ed.) The Grass Crop. London: Chapman and Hall, 1988, p.85-127. 
DAVIES, A.; THOMAS, H. Rates of leaf and tiller production in young spaced perennial ryegrass plants in relation to soil-temperature and solar-radiation. Annals of Botany, v.51, n.5, p.591-597, 1983.

DAVIES, A.; EVANS, M.E.; EXLEY, J.K. Regrowth of perennial ryegrass as affected by simulated leaf sheaths. Journal of Agricultural Science, v.101, p.131-137, 1983.

DEAN, T.J.; LONG, J.N. Response of self-thinning to artificially reduced levels of leaf-area in monocultures of trifolium-pratense. Annals of Botany, v.55, n.3, p.361-366, 1985.

DEREGIBUS, V.A.; SANCHEZ, R.A.; CASAL, J.J. Effects of light qua lity on tiller production in lolium spp. Plant Physiology, v.72, n.3, p.900-902, 1983.

DEREGIBUS, V.A.; SANCHEZ, R.A.; CASAL, J.J.; TRLICA, M.J. Tillering responses to enrichment of red-light beneath the canopy in a humid natural grassland. Journal of Applied Ecology, v.22, n.1, p.199-206, 1985.

DURU, M.; JUSTES, E.; LANGLET, A.; TIRILly, V. Comparison of organ appearance and senescence rates in tall fescue, cocksfoot and lucerne. Agronomie, v.13, p.237-252, 1993.

ECKSTEIN, R. L.; KARLSSON, P. S.; WEIH, M. Leaf lifespan and nutrient resorption as determinants of plant nutrient conservation in temperate-arctic regions. New Phytologist. v.143, p.177-189, 1999. 
EMPRESA BRASILEIRA DE PESQUISA AGROPECUÁRIA. Sistema brasileiro de classificação de sol os. Brasília: EMBRAPA, 1999. 412p. (Produção de Informação).

ENQUIST, B.J.; WEST, G.B.; CHARNOV, E.L.; BROWN, J.H. Allometric scaling of production and life-history variation in vascular plants. Nature, v.401, n.6756, p.907-911, 1999.

ESCUDERO, A.; DEL ARCO, J. M.; SANZ, I. C.; AYALA, J. Effects of leaf longevity and retranslocation efficiency on the retention time of nutrients in the leaf biomass of different woody species. Oecologia, v.90, p.80-87, 1992

EVANS, M.W.; GROVER, F.O. Developmental morp hology of the growing point of the shoot and the inflorescence in grasses. Journal of Agricultural Research, v.61, n.7, p.481-520, 1940.

FAGUNDES, J.L.; DA SILVA, S.C.; PEDREIRA, C.G.S.; SBRISSIA, A.F.; CARNEVALLI, R.A.; CARVALHO, C.A.B.; PINTO, L.F.M. Índice de área foliar, interceptação luminosa e acúmulo de forragem em pastagens de cynodon spp. Sob diferentes intensidades de pastejo. Scientia Agricola, v.56, n.4, p.1141-1150, 1999.

FARIA, V.P.; PEDREIRA, C.G.S.; SANTOS, F.A.P. Evolução e uso de pastagens para bovinos. In: SIMPÓSIO SOBRE MANEJO DA PASTAGEM, 13., Piracicaba, 1996. Anais. Piracicaba: FEALQ, 1996. p. 1-14.

HERNÁNDEZ-GARAY, A.H.; MATTHEW, C.; HODGSON, J. Effect of spring grazing management on perennial ryegrass and ryegrass white clover pastures .2 . Tiller and growing point densities and population dynamics. New Zealand Journal of Agricultural Research, v.40, n.1, p.37-50, 1997. 
HERNÁNDEZ-GARAY, A.H.; MATTHEW, C.; HODGSON, J. Tiller size/density compensation in perennial ryegrass miniature swards subject to differing defoliation heights and a proposed productivity index. Grass and Forage Science, v.54, n.4, p.347-356, 1999.

GAUTIER, H.; VARLETGRANCHER, C. Regulation of leaf growth of grass by blue light. Physiologia Plantarum, v.98, n.2, p.424-430, 1996.

GAUTIER, H.; VARLET-GRANCHER, C.; HAZARD, L. Tillering responses to the light environment and to defoliation in populations of perennial ryegrass (lolium perenne 1.) selected for contrasting leaf length. Annals of Botany, v.83, n.4, p.423429, 1999.

GHISI, O. M. A.; PEDREIRA, J. V. S. Características agronômicas das principais Brachiaria spp. In: PEDREIRA, J. V. S.; MEIRELLES, N. M. F. (Ed.). ENCONTRO SOBRE CAPINS DO GÊNERO Brachiaria, Nova Odessa, 1986. Anais. Nova Odessa, SP: Instituto de Zootecnia, 1987. p. 19-58.

GOMIDE J. A. Morfogênese e análise de crescimento de gramíneas tropicais. In: SIMPÓSIO INTERNACIONAL SOBRE PRODUÇÃO ANIMAL EM PASTEJO, Viçosa, 1997. Anais. Viçosa: UFV, 1997. p. 97-115.

GOMIDE J. A.; GOMIDE, C. A. M. Fundamentos e estratégia do manejo de pastagens. In: SIMPÓSIO DE PRODUÇÃO DE GADO DE CORTE, 1, Viçosa: UFV, 1999, Anais. Viçosa, 1999. p. 179-200.

GONÇALVES, A.C. Características morfogênicas e padrões de desfolhação em pastos de capim-Marandu submetidos a regimes de lotação contínua. Piracicaba, 2003. 124p. Dissertação (Mestrado) - Escola Superior de Agricultura “Luiz de Queiroz", Universidade de São Paulo. 
GRANT, S. A.; KING, J. Grazing management and pasture production: the importance of sward morphological adaptations and canopy photosynthesis. In: THE HILL FARMING RESEARCH ORGANISATION. Edinburgh, Escócia. 1982-83. Palmerston North, 1983. p. 119-129. (Biennial report)

GRANT, S. A.; MARRIOTT, C. A. Detailed studies of grazer swards - techniques and conclusions. Journal of Agricultural Science, v. 122, p. 1-6, 1994.

GRANT, S.A.; BARTHRAM, G.T.; TORVELL, L.; KING, J.; SMITH, HK. Sward management, lamina turnover and tiller population-density in continuously stocked lolium-perenne-dominated swards. Grass and Forage Science, v.38, n.4, p.333344, 1983.

HIRATA, M.; PAKIDING, W. Tiller dynamics in a bahia grass (paspalum notatum) pasture under cattle grazing. Tropical Grasslands, v.35, n.3, p.151-160, 2001.

HODGSON, J. Nomenclature and definitions in grazing studies. Grass and Forage Science, v.34, p.11-18, 1979.

HODGSON, J. Grazing management: science into pratice. New York: John Wiley; Longman Scientific and Technical, Longman, 1990. 203p.

HODGSON, J. BIRCHAM, J.S.; GRANT, S.A.; KING, J. The influence of cutting and grazing management on herbage growth and utilization. In: SIMPOSIUM ON PLANT PHYSIOLOGY AND HERBAGE PRODUCTION, Nottingham, 1981. Proceedings. Belfast: British Grassland Society, 1981. p.51-62.

HOWARD, R.A. The stem node leaf continuum of the Dicotiledoneae. Journal of the Arnold Arboretum of Harvard University, v.55, p.125-181, 1974. 
HUBER, H.; LUKACS, S.; WATSON, M.A. Spatial structure of stoloniferous herbs: an interplay between structural blue-print, ontogeny and phenotypic plasticity. Plant Ecology, v.141, n.1/2, p.107-115, 1999.

JEWISS, O.R. Morphological and physiological aspects of the growth of grasses during the vegetative phase. In: MILTHORPE, F.L.; IVINS, J.D. (Ed.) The Growth of Cereals and Grasses, London: Butterworths, 1966. p.39-56.

JEWISS, O. R.. Tillering in grasses: Its significance and control. Journal of the British Grassland Society, v. 72, p. 65-82, 1972.

JOLLIFFE, I. T. Pincipal component analysis. New York: Springer-Verlag; 1986. $271 p$.

KAYS, S.; HARPER, J.L. The regulation of plant and tiller density in a grass sward. Jounal of Ecology, v.62, p.97-105, 1974.

KORTE, C.J.; WATKIN, B.R.; HARRIS, W. Effects of the timing and intensity of spring grazings on reproductive development, tillering, and herbage production of perennial ryegrass dominant pasture. New Zealand Journal of Agricultural Research, v.27, n.2, p.135-149, 1984.

LABARBERA, M. Analyzing body size as a factor in ecology and evolution. Annual Review of Ecology and Systematics, v.20, p.97-117, 1989.

LAMBERT, M.G.; CLARK, D.A.; GRANT, D.A.; COSTALL, D.A.; GRAY, Y.S. Influence of fertiliser and grazing management on North Island moist hill country 4. Pastures species abundance. New Zealand Journal of Agricultural Research, v.29, p.23-31, 1986. 
LANGER, R.H.M. Changes in the tiller population of grass swards. Nature, v.182, p.1817-1818, 1958.

LANGER, R.H.M. Tillering in herbage grasses. Herbage Abstracts, v.33, n.3, p.141148, 1963.

LANGER, R. H. M. How grasses grow. London: The Institute of Biology's Studies, 1972. 60p. (Studies in Biology).

LANGER, R.H.M. Tillering. In: LANGER, R.H.M (Ed). How grasses grow. London: Edward Arnold, 1979. cap.5, p.19-25.

LEMAIRE, G.; CULLETON, N. Effects of nitrogen applied after the last cut in autumn on a tall fescue sward. II. Uptake and recycling of nitrogen in the sward during winter. Agronomie, v.9, p.241-249, 1989.

LEMAIRE, G.; CHAPMAN, D. Tissue flows in grazed plant communities. In: HODGSON, J.; ILLIUS A. W. (Ed.). The ecology and management of grazing systems. London: CAB International, 1996. cap. 1. p. 3-36.

LEMAIRE, G.; AGNUSDEI, M. Leaf tissue turn-over and efficiency of herbage utilization In: LEMAIRE, G.; HODGSON, J.; MORAES, A.; CARVALHO, P.C.F.; NEBINGER, C. (Ed.) Grassland Ecophysiology and Grazind Ecology. Wallingford: CABI Publishing, 2000. cap. 14, p.265-287.

LEMOS-FILHO, J.P.; VILLA-NOVA, N.A.; PINTO, H.S. A model including photoperiod in degree days for estimating Hevea bud growth. International Journal of Biometeorology, v.41, p.1-4, 1997. 
LESLIE, P.H. On the use of matrices in certain population mathematics. Biometrika, v.33, n.3, p.183-212, 1945.

LITTEL, R.C.; PENDERGAST, J.; NATARAJAN, R. Modelling covariance structure in the analysis of repeated measures data. Statistics in Medicine, v.19, p.17931819, 2000.

LOUAULT, F.; CARRERE, P.; SOUSSANA, J.F. Efficiencies of ryegrass and white clover herbage utilization in mixtures continuously grazed by sheep. Grass and Forage Science, v.52, n.4, p.388-400, 1997.

LOUIE, K.; CLARK, H.; NEWTON, P.C.D. Analysis of differential equation models in biology: a case study for clover meristem populations. New Zealand Journal of Agricultural Research, v.41, n.4, p.567-576, 1998.

MARSHALL, C. Physiological aspects of pasture growth. In: SNAYDON, R.W. (Ed.). Managed Grasslands. Amsterdam: Elsevier, 1987. cap. 4, p.29-46.

MATTHEW, C. A study of seasonal root and tiller dynamics in swards of perennial ryegrass (Lolium perenne L.). Palmerston North, 1992. 210p. Thesis (Ph.D.) Massey University.

MATTHEW, C.; BLACK, C.K.; BUTLER, B.M. Tiller dynamics of perennation in three herbage grasses. In: INTERNATIONAL GRASSLAND CONGRESS, 17., Palmerston North, 1993. Proceedings, Wellington, New Zealand: Sir Publishing, 1993. p.141-143. 
MATTHEW, C.; LAWOKO, C.R.O.; KORTE, C.J.; SMITH, D. Application of canonical discriminant-analysis, principal component analysis, and canonical correlation-analysis as tools for evaluating differences in pasture botanical composition. New Zealand Journal of Agricultural Research, v.37, n.4, p.509$520,1994$.

MATTHEW, C.; LEMAIRE, G.; HAMILTON, N.R.S.; HERNÁNDEZ-GARAY, A. H. A modified self-thinning equation to describe size/density relationships for defoliated swards. Annals of Botany, v.76, n.6, p.579-587, 1995.

MATTHEW, C.; ASSUERO, S. G.; BLACK, C. K.; SACKVILLE-HAMILTON, N. R. Tiller dynamics of grazed swards. In: LEMAIRE, G.; HODGSON, J.; MORAES, A.; CARVALHO, P.C.F.; NEBINGER, C. (Ed.) Grassland Ecophysiology and Grazind Ecology. Wallingford: CABI Publishing, 2000. cap. 7, p.127-150.

MATTHEW, C. Translocation from flowering to daughter tillers in perennial ryegrass (lolium perenne 1.). Australian Journal of Agricultural Research, v.53, n.1, p.2128, 2002.

MAZZANTI, A.; LEMAIRE, G. Effect of nitrogen fertilization on herbage production of tall fescue swards continuously grazed by sheep .2. Consumption and efficiency of herbage utilization. Grass and Forage Science, v.49, n.3, p.352-359, 1994.

MAZZANTI, A. Adaptación de especies forrajeras a la defolicion. In: SIMPÓSIO SOBRE AVALIACÃO DE PASTAGENS COM ANIMAIS, Maringá, 1997. Anais. Maringá: Coper Graf - Artes Gráficas, 1997. p.75-84.

McMAHON, C. Size and shape in biology. Science, v.179, p.1201-1204, 1973. 
McMAHON, C.; KRONAUER, R.E. Tree structures: deducing the principle of mechanical design. Journal of Theoretical Biology, v.59, p.443-466, 1976.

McINTYRE, G.I.; CESSNA, A.J. Apical dominance in Phaseolus vulgaris: effect of the nitrogen supply. Canadian Journal of Botany, v.69, p.1337-1343, 1991.

MORRONE, O.; ZULOAGA, F.O. Revision de las especies sudamericanas nativas e introducidas de los generos Brachiaria y Urochloa (Poaceae: Panicoideae: Paniceae). Darwiniana, v.31, p.43-109, 1992.

MURPHY, J.S.; BRISKE, D.D. Regulation of tillering by apical dominance chronology, interpretive value, and current perspectives. Journal of Range Management, v.45, n.5, p.419-429, 1992.

MYERS, R.L.; BRUN, W.A.; BRENNER, M.L. Effect of raceme-localized supplemental light on soybean reproductive abscission. Crop Science. v.27, p.273$277,1987$.

NABINGER, C. Eficiência do uso de pastagens: disponibilidade e perdas de forragem. In: SIMPÓSIO SOBRE MANEJO DA PASTAGEM, 14., Piracicaba, 1997. Anais. Piracicaba: FEALQ, 1997. p. 213-251.

NELSON, C.J. Shoot morphological plasticity of grasses: Leaf growth vs. Tillering. In: LEMAIRE, G.; HODGSON, J.; MORAES, A.; CARVALHO, P.C.F.; NEBINGER, C. (Ed.) Grassland Ecophysiology and Grazind Ecology. Wallingford: CABI Publishing, 2000. cap. 6, p.101-126.

NIKLAS, K.J. Plant allometry: the scaling process. Chicago: University of Chicago Press, 1994. 
NIKLAS, K.J.; ENQUIST, B.J. Invariant scaling relationships for interspecific plant biomass production rates and body size. Proceedings of the National Academy of Sciences of the United States of America, v.98, n.5, p.2922-2927, 2001.

NIKLAS, K.J.; MIDGLEY, J.J.; ENQUIST, B.J. A general model for mass-growthdensity relations across tree-dominated communities. Evolutionary Ecology Research, v.5, n.3, p.459-468, 2003.

NOVOPLANSKY, A.; SACHS, T.; COHEN, D.; BAR, R.; BODENHEIMER, J.; REISFELD, R. Increasing plant productivity by changing the solar spectrum. Solar Energy Mater, v.21, p.17-23, 1990.

NUNES, S. G.; BOOK, A.; PENTEADO, M. I. DE O.; GOMES, D. T. Brachiaria brizantha cv. Marandu. 2.ed. Campo Grande: EMBRAPA CNPGC, 1985. 31p. (EMBRAPA-CNPGC, Documentos, 21).

OLSON, B.E.; RICHARDS, J.H. Annual replacement of the tillers of Agropyron desertorum following grazing. Oecologia, v.76, p.1-6, 1988.

OMETTO, J. C. Bioclimatologia vegetal. São Paulo: Agronômica CERES, 1981. 425p.

PAKIDING, W.; HIRATA, M. Leaf appearance, death and detachment in a bahia grass (Paspalum notatum) pasture under cattle grazing. Tropical Grasslands, v.35, n.2, p.114-123, 2001.

PARSONS, A.J.; JOHNSON, I.R.; HARVEY, A. Use of a model to optimize the interaction between frequency and severity of intermittent defoliation and to provide a fundamental comparison of the continuous and intermittent defoliation of grass. Grass and Forage Science, v.43, p.49-59, 1988. 
PARSONS, A.J.; LEAFE, E.L.; COLLETT, B.; STILES, W. The physiology of grass production under grazing .1. Characteristics of leaf and canopy photosynthesis of continuously-grazed swards. Journal of Applied Ecology, v.20, n.1, p.117-126, 1983a.

PARSONS, A.J.; LEAFE, E.L.; COLLETT, B.; STILES, W. The physiology of grass production under grazing. 1.characteristics of leaf and canopy photosynthesis of continuously grazed swards. Journal of Applied Ecology, v.20, p.117-126, 1983b.

PETERNELLI, M. Características Morfogênicas e Estruturais do Capim-braquiarão [Brachiaria brizantha (hochst ex a. rich.) stapf. cv. marandu] sob Intensidades de pastejo. Pirassununga, 2003. 79p. Dissertação (Mestrado) - Faculdade de Zootecnia e Engenharia de Alimentos, Universidade de São Paulo.

PINTO, J. C.; GOMIDE, J. A.; MAESTRI, M.; LOPES, N. F. Crescimento de folhas de gramíneas forrageiras tropicais, cultivadas em vasos, com duas doses de nitrogênio. Revista da Sociedade Brasileira de Zootecnia, v.23, p.327-332, 1994.

PINTO, L. F. M. Dinâmica do acúmulo de matéria seca em pastagens de Cynodon spp. Piracicaba, 2000. 124p. Dissertação (Mestrado) - Escola Superior de Agricultura “Luiz de Queiroz”, Universidade de São Paulo.

PINTO, L. F. M., DA SILVA, S. C., SBRISSIA, A. F.; CARVALHO, C.A.B.; CARNEVALLI, R.A.; FAGUNDES, J.L.; PEDREIRA, C.G.S. Dinâmica do acúmulo de matéria seca em pastagens de Tifton 85 sob pastejo. Scientia Agricola, v.58, n.3, p.439-447, 2001.

PRASAD, T.K.; HOSOKAWA, Z.; CLINE, M.G. Effects of auxin, auxin-transport inhibitors and mineral nutrients on apical dominance in Pharbitis nil. Journal of Plant Physiology, v.135, p.472-477, 1989. 
PRETZSCH, H. A unified law of spatial allometry for woody and herbaceous plants. Plant Biology, v.4, n.2, p.159-166, 2002.

RAIJ, B. VAN; QUAGGIO, J. A.; SILVA, N. M. Extraction of phosphorus, potassium, calcium, and magnesium from soils by ion-exchange resin procedure. Communications in Soil Science and Plant Analysis, v.17, n.5, p.547-566, 1986.

RAIJ, B. VAN; CANTARELlA, H.; QUAGGIO, J. A.; FURLANI, A. M. C. (Ed.). Recomendações de adubação e calagem para o Estado de São Paulo. 2. ed. Campinas: Instituto Agronômico; Fundação IAC, 1996. 258p. (Boletim Técnico, 100).

RENVOIZE, S. A.; CLAYTON, W. D.; SKABUYE, C. H. Morfología, taxonomía y distribución natural de Brachiaria (Trin.) Griseb. In: MILLES, J. W.; MASS, B. L.; VALLE, B. C. (Ed.). Brachiaria: biología, agronomía y mejoramiento. Cali: CIAT; Campo Grande: EMBRAPA CNPGC, 1998. cap. 1, p. 1-15.

ROBSON, M.J. A comparison of British and North-African variety of Tall fescue (Festuca arundinacea). I. Leaf growth during winter and the effects on temperature and day length. Journal of Applied Ecology, v.4, p.475-484, 1967.

RYSER, P. The importance of tissue density for growth and life-span of leaves and roots: comparison of five ecologically contrasting grasses. Functional Ecology. v,10, p.717- 723, 1996.

RYSER, P.; URBAS, P. Ecological significance of leaf life span among Central European grass species. Oikos, v.91, n.1, p41-50, $2000 .$. 
RUTISHAUSER, R.; SATTLER, R. Complementarity and heuristic value of contrasting models in structural botany. I. General considerations. Botanische Jahrbücher für Systematik, v.109, p.415-455, 1985.

SACKVILLE-HAMILTON, N.R.; MATTHEW, C.; LEMAIRE, G. In defence of the $-3 / 2$ boundary rule: a re-evaluation of self thinning concepts and status. Annals of Botany, v.76, p.569-577, 1995.

SALISBURY, F. B.; ROSS, C. W. Plant physiology. 4.ed. California: Wadsworth Publishing Company, 1992.682p.

SANTOS, P.M.. Controle do desenvolvimento das hastes no capim Tanzânia: um desafio. Piracicaba, 2002. 98p. Tese (Doutorado) - Escola Superior de Agricultura "Luiz de Queiroz", Universidade de São Paulo.

SARMENTO, D.O.L. Comportamento Ingestivo de Bovinos em Pastos de capimMarandu submetidos a regimes de lotação contínua. Piracicaba, 2003. 76p. Dissertação (Mestrado) - Escola Superior de Agricultura "Luiz de Queiroz", Universidade de São Paulo.

SAS INSTITUTE. http://v8doc.sas.com/sashtml/. (05 de fevereiro de 2004).

SATTLER, R.; RUTISHAUSER, R. The fundamental relevance of morpholoy and morphogenesis to plant research. Annals of Botany, v.80, p.571-582, 1997.

SBRISSIA, A. F.; DA SILVA, S. C. O ecossistema de pastagens e a produção animal. In: MATTOS, W. R. S. (Ed.) A produção animal na visão dos brasileiros, Piracicaba: SBZ, 2001. p.731-754. 
SBRISSIA, A. F.; DA SILVA, S. C.; CARVALHO, C. A. B.; CARNEVALlI, R. A.; PINTO, L. F. M.; FAGUNDES, J. L.; PEDREIRA, C. G. S. Tiller size/population density compensation in Coastcross grazed swards. Scientia Agrícola, v.58, n.4, p.655-665, 2001.

SBRISSIA, A.; DA SILVA, S.; MATTHEW, C.; CARVALHO, C.; CARNEVALLI, R.; PINTO, L.; FAGUNDES, J.; PEDREIRA, C. Tiller size/density compensation in grazed Tifton 85 bermudagrass swards. Pesquisa Agropecuária Brasileira, v.38, n.12, p.1459-1468, 2003.

SCHLAPFER, B.; RYSER, P. Leaf and root turnover of three ecologically contrasting grass species in relation to their performance along a productivity gradient. Oikos, v.75, n.3, p.398-406, 1996.

SCHNYDER, H.; SCHÄUFELE. R.; DE VISSER, R.; NELSON, C.J. An integrated view of $\mathrm{C}$ and $\mathrm{N}$ uses in the leaf growth zones of defoliated grasses. In: LEMAIRE, G.; HODGSON, J.; MORAES, A.; CARVALHO, P.C.F.; NABINGER, C. (Ed.). Grassland Ecophysiology and Grazing Ecology. Wallingford: CABI publishing, 2000. p.41-60.

SILSBURY, J.H. Leaf growth in pasture grasses. Tropical Grasslands, v.4, n.1, p.1736, 1970.

SKALOVA, H.; KRAHULBC, F. The response of 3 festuca-rubra clones to changes in light quality and plant-density. Functional Ecology, v.6, n.3, p.282-290, 1992.

SKALOVA, H.; KRAHULBC, F.; DURING, H.J.; HADINCOVA, V.; PECHACKOVA, S.; HERBEN, T. Grassland canopy composition and spatial heterogeneity in the light quality. Plant Ecology, v.143, n.2, p.129-139, 1999. 
SKERMAN, P. J.; RIVEROS, F. Gramíneas tropicales. Roma: FAO, 1992. 832p. (Colección FAO: Producción y protección vegetal, 23).

SKINNER, R.H.; NELSON, C.J. Estimation of potential tiller production and site usage during tall fescue canopy development. Annals of Botany, v.70, n.6, p.493499, 1992.

SKINNER, R.H.; NELSON, C.J. Elongation of the grass leaf and its relationship to the phyllochron. Crop Science, v.35, n.1, p.4-10, 1995.

SOARES FILHO, C.V.; MONTEIRO, F.A.; CORSI, M. Recuperação de pastagens degradadas de brachiaria decumbens. 2. Variação sazonal de parâmetros bioquímico-fisiológicos. Pasturas Tropicales, v.14, n.2, p.7-13, 1992.

VALENTINE, I.; MATTHEW, C. Plant growth, development and yield. In: WHITE, J.; HODGSON, J. (Ed.). New Zealand - Pasture and Crop Science, Oxford: Cambridge University Press, 1999. p.11-27.

VAN DER WAL, R.; EGAS, M.; VAN DER VEEN, A.; BAKKER, J. Effects of resource competition and herbivory on plant performance along a natural productivity gradient. Journal of Ecology, v.88, n.2, p.317-330, 2000.

VAN ESBROECK, G. A.; HUSSEY, M. A.; SANDERSON, M. A. Leaf appearance rate and final leaf number of switchgrass cultivars. Crop Science, v. 37, p. 864870, 1997. 
VILLA NOVA, N.A.; CARRETEIRO, M.V.; SCARDUA, R. Um modelo para avaliação do crescimento de cana-de-açúcar (Sacharum spp.) em termos da ação combinada do fotoperíodo e da temperatura média do ar. In: CONGRESSO BRASILEIRO DE AGROMETEOROLOGIA, 2., Campinas, 1983, Anais. Sociedade Brasileira de Agrometeorologia/Instituto Agronômico de Campinas: Sociedade Brasileira de Agrometeorologia/Instituto Agronômico de Campinas, 1983. p.31-48.

VOGEL, W.G.; BJUGSTAD, A.J. Effects of clipping on yield and tillering of little bluestem, big bluestem, and indiangrass. Journal of Range Management, v.21, p.136-140, 1968.

WAN, C.G.; SOSEBEE, R.E. Tillering responses to red : Far-red light ratio during different phenological stages in eragrostis curvula. Environmental and Experimental Botany, v.40, n.3, p.247-254, 1998.

VAN DER WERF, A.; GEERTS, R. H. E. M.; JACOBS, F.H.H. et al. The importance of relative growth rate and associated traits for competition between species during vegetational succession. In: LAMBERS, H.; POORTER, H.; VAN VUUREN, M. M. I. (Ed.). Inherent variation in plant growth: Physiological mechanisms and ecological consequences. Backhuys: Backhuys Publishers, 1998. p.489-502.

WEBSTER, R. D. Genera of the North American Paniceae (Poaceae: Panicoideae). Systematic Botany, v.13, n.4, p.576-609, 1987.

WEST, G.B.; BROWN, J.H.; ENQUIST, B.J. A general model for the origin of allometric scaling laws in biology. Science, v.276, n.5309, p.122-126, 1997.

WEST, G.B.; BROWN, J.H.; ENQUIST, B.J. A general model for the structure and allometry of plant vascular systems. Nature, v.400, n.6745, p.664-667, 1999. 
WESTOBY, M. The self-thinning rule. Advances in Ecological Research, v.14, p.41$76,1984$.

WHITE, J. The plant as a metapopulation. Annual Reviews of Ecology and Systematics, v.10, p.109-145, 1979.

WHITE, J. Plant metarism. In: DIRZO, R. SARUKHAN, J. (Ed.) Perspectives on plant population ecology. Sunderland: Sinauer, 1984. p.15-47.

WILHELM, W.W.; MCMAS TER, G.S. Importance of the phyllochron in studying development and growth in grasses. Crop Science, v.35, n.1, p.1-3, 1995.

WILMAN, D.; MARES MARTINS, V. M. Senescence and death of herbage during periods of regrowth in ryegrass and red and white clover, and the effect of applied nitrogen. Journal of Applied Ecology, v. 14, p. 615-620, 1977.

WILSON, R.E.; LAIDLAW, A.S. The role of the sheath tube in the development of expanding leaves in perennial ryegrass. Annals of Applied Biology, v.106, p.385$391,1985$.

XIA, J.X. The effects of defoliation on tissue turnover and pasture production in perennial ryegrass, prairie grass, and smooth bromegrass, pasture. Palmerston North, 1991. 173p. Thesis (Ph.D.) - Massey University.

YANG, J.Z.; MATTHEW, C.; ROWLAND, R.E. Tiller axis observations for perennial ryegrass (lolium perenne) and tall fescue (festuca arundinacea): Number of active phytomers, probability of tiller appearance, and frequency of root appearance per phytomer for three cutting heights. New Zealand Journal of Agricultural Research, v.41, n.1, p.11-17, 1998. 
YODA, K.; KIRA, T.; OGAWA, H.; HOZUMI, K. Intraspecific competition among higher plants. XI Self-thinning in overcrowded pure stands under cultivate and natural conditions. Journal of Institute of Polytechnics, v.14, p.107-129, 1963.

ZARROUGH, K.M.; NELSON, C.J.; SLEPER, D.A. Interrelatonsships btweem rates of appearance and tillering in selected tall fescue populations. Crop Science, v.24, p.565-569, 1984. 
APÊNDICES 


\section{APÊNDICE 1}

Radiação solar global, insolação diária, precipitação total e temperaturas médias mensais do ar (mínima, média e máxima) durante o período experimental.

\begin{tabular}{|c|c|c|c|c|c|c|c|}
\hline \multirow{3}{*}{ Mês } & \multirow{3}{*}{ Epoca } & \multirow{3}{*}{$\begin{array}{l}\text { Radiação } \\
\text { global } \\
\text { cal cm² dia }{ }^{-1}\end{array}$} & \multirow{3}{*}{$\begin{array}{c}\text { Insolação } \\
\text { diária } \\
\text { horas.dia }^{-1}\end{array}$} & \multirow{3}{*}{$\begin{array}{c}\text { Precipitação } \\
\text { Total } \\
\text { mm }\end{array}$} & \multicolumn{3}{|c|}{ Temperatura $\left({ }^{\circ} \mathrm{C}\right)$} \\
\hline & & & & & & & \\
\hline & & & & & média & & média \\
\hline \multirow{2}{*}{ Novembro } & 2001 & 466 & 6,7 & 152,4 & 18,7 & 24,7 & 30,7 \\
\hline & Média 85 anos & 472 & 7,4 & 130,6 & 16,7 & 23,1 & 29,6 \\
\hline \multirow{2}{*}{ Dezembro } & 2001 & 427 & 5,4 & 204,2 & 18,7 & 24,0 & 29,2 \\
\hline & Média 85 anos & 450 & 6,6 & 201,0 & 18,2 & 23,9 & 29,6 \\
\hline \multirow{2}{*}{ Janeiro } & 2002 & 410 & 4,7 & 320,2 & 19,3 & 24,5 & 29,8 \\
\hline & Média 85 anos & 447 & 6,3 & 225,6 & 19,0 & 24,6 & 30,0 \\
\hline \multirow{2}{*}{ Fevereiro } & 2002 & 404 & 5,1 & 187,9 & 18,8 & 23,9 & 29,0 \\
\hline & Média 85 anos & 438 & 6,5 & 184,1 & 19,0 & 24,6 & 30,2 \\
\hline \multirow{2}{*}{ Março } & 2002 & 462 & 7,9 & 272,4 & 19,5 & 25,8 & 32,0 \\
\hline & Média 85 anos & 402 & 6,8 & 144,7 & 18,2 & 24,1 & 30,0 \\
\hline \multirow{2}{*}{ Abril } & 2002 & 393 & 8,7 & 27,2 & 17,6 & 24,7 & 31,8 \\
\hline & Média 85 anos & 373 & 7,5 & 63,1 & 15,4 & 21,9 & 28,4 \\
\hline \multirow{2}{*}{ Maio } & 2002 & 298 & 6,1 & 112,4 & 14,5 & 20,7 & 26,9 \\
\hline & Média 85 anos & 302 & 7,2 & 52,9 & 12,1 & 19,1 & 26,1 \\
\hline \multirow{2}{*}{ Junho } & 2002 & 307 & 7,4 & 0,0 & 12,6 & 20,3 & 27,9 \\
\hline & Média 85 anos & 281 & 7,1 & 43,2 & 10,3 & 17,6 & 25,0 \\
\hline \multirow{2}{*}{ Julho } & 2002 & 267 & 6,0 & 23,4 & 10,2 & 17,7 & 25,2 \\
\hline & Média 85 anos & 305 & 7,8 & 27,1 & 9,5 & 17,4 & 25,3 \\
\hline \multirow{2}{*}{ Agosto } & 2002 & 317 & 6,7 & 79,6 & 14,3 & 21,6 & 28,9 \\
\hline & Média 85 anos & 353 & 8,1 & 30,5 & 11,0 & 19,2 & 27,3 \\
\hline \multirow{2}{*}{ Setembro } & 2002 & 340 & 5,8 & 45,6 & 13,6 & 20,6 & 27,5 \\
\hline & Média 85 anos & 378 & 6,8 & 63,5 & 13,4 & 20,7 & 28,1 \\
\hline \multirow{2}{*}{ Outubro } & 2002 & 431 & 7,4 & 49,4 & 18,8 & 26,3 & 33,8 \\
\hline & Média 85 anos & 437 & 6,9 & 110,3 & 15,6 & 22,3 & 29,0 \\
\hline \multirow{2}{*}{ Novembro } & 2002 & 432 & 5,7 & 176,4 & 18,8 & 24,7 & 30,6 \\
\hline & Média 85 anos & 472 & 7,4 & 131,2 & 16,7 & 23,1 & 29,6 \\
\hline \multirow{2}{*}{ Dezembro } & 2002 & 460 & 6,0 & 164,7 & 19,7 & 25,4 & 31,1 \\
\hline & Média 85 anos & 450 & 6,6 & 200,6 & 18,2 & 23,9 & 29,6 \\
\hline
\end{tabular}




\section{APÊNDICE 2}

Resultados do balanço hídrico mensal do primeiro decêndio de novembro/2001 ao terceiro decêndio de dezembro/2002.

\begin{tabular}{|c|c|c|c|c|c|c|}
\hline \multirow{3}{*}{ Ano } & \multicolumn{2}{|l|}{ Epoca } & \multicolumn{2}{|c|}{ Precipitação } & \multirow{2}{*}{ Deficiência } & \multirow{2}{*}{ Excedente } \\
\hline & \multirow{2}{*}{ Mês } & \multirow{2}{*}{ Dias } & Temperatura ${ }^{\circ} \mathrm{C}$ & Total & & \\
\hline & & & & $\mathrm{mm}$ & \multicolumn{2}{|c|}{$\mathrm{mm}$} \\
\hline \multirow{3}{*}{2001} & \multirow{3}{*}{ Novembro } & $1-10$ & 23,85 & 5,50 & $-15,5$ & 0,0 \\
\hline & & $11-20$ & 24,17 & 98,00 & 0,0 & 29,5 \\
\hline & & $21-30$ & 26,05 & 48,90 & 0,0 & 5,1 \\
\hline \multirow{3}{*}{2001} & \multirow{3}{*}{ Dezembro } & $1-10$ & 23,76 & 32,80 & 0,0 & 0,0 \\
\hline & & $11-20$ & 24,89 & 64,20 & 0,0 & 25,5 \\
\hline & & $21-31$ & 23,33 & 107,20 & 0,0 & 73,6 \\
\hline \multirow{3}{*}{2002} & \multirow{3}{*}{ Janeiro } & $1-10$ & 24,79 & 117,00 & 0,0 & 83,2 \\
\hline & & $10-21$ & 22,55 & 74,80 & 0,0 & 48,4 \\
\hline & & $21-31$ & 26,15 & 128,40 & 0,0 & 84,7 \\
\hline \multirow{3}{*}{2002} & \multirow{3}{*}{ Fevereiro } & $1-10$ & 23,28 & 133,30 & 0,0 & 103,8 \\
\hline & & $11-20$ & 24,22 & 19,30 & $-1,8$ & 0,0 \\
\hline & & $21-28$ & 24,36 & 35,30 & $-0,7$ & 0,0 \\
\hline \multirow{3}{*}{2002} & \multirow{3}{*}{ Março } & $1-10$ & 25,92 & 42,30 & 0,0 & 0,0 \\
\hline & & $11-20$ & 26,66 & 105,50 & 0,0 & 46,8 \\
\hline & & $21-31$ & 24,87 & 124,60 & 0,0 & 86,1 \\
\hline \multirow{3}{*}{2002} & \multirow{3}{*}{ Abril } & $1-10$ & 24,56 & 23,10 & $-2,0$ & 0,0 \\
\hline & & $11-20$ & 25,14 & 0,00 & $-20,2$ & 0,0 \\
\hline & & $21-30$ & 24,35 & 4,10 & $-29,4$ & 0,0 \\
\hline \multirow{3}{*}{2002} & \multirow{3}{*}{ Maio } & $1-10$ & 22,71 & 28,30 & $-3,4$ & 0,0 \\
\hline & & $11-20$ & 21,85 & 43,40 & 0,0 & 0,0 \\
\hline & & $21-31$ & 17,75 & 40,70 & 0,0 & 0,0 \\
\hline \multirow{3}{*}{2002} & \multirow{3}{*}{ Junho } & $1-10$ & 20,91 & 0,00 & $-8,4$ & 0,0 \\
\hline & & $11-20$ & 21,14 & 0,00 & $-16,7$ & 0,0 \\
\hline & & $21-30$ & 18,78 & 0,00 & $-16,9$ & 0,0 \\
\hline \multirow{3}{*}{2002} & \multirow{3}{*}{ Julho } & $1-10$ & 17,59 & 0,00 & $-9,5$ & 0,0 \\
\hline & & $11-20$ & 15,61 & 6,00 & $-2,6$ & 0,0 \\
\hline & & $21-31$ & 19,70 & 17,40 & $-2,0$ & 0,0 \\
\hline
\end{tabular}


Resultados do balanço hídrico mensal do primeiro decêndio de novembro/2001 ao terceiro decêndio de dezembro/2002.

\begin{tabular}{|c|c|c|c|c|c|c|}
\hline \multirow[b]{2}{*}{ Ano } & \multicolumn{2}{|l|}{ Epoca } & \multirow[b]{2}{*}{ Temperatura ${ }^{\circ} \mathrm{C}$} & \multirow{2}{*}{$\begin{array}{c}\text { Precipitação } \\
\text { Total } \\
\text { mm }\end{array}$} & \multirow{2}{*}{$\begin{array}{l}\text { Deficiência } \\
\qquad \mathrm{mm}\end{array}$} & \multirow{2}{*}{ Excedente } \\
\hline & Mês & Dias & & & & \\
\hline \multirow{3}{*}{2002} & \multirow{3}{*}{ Agosto } & $1-10$ & 21,75 & 58,80 & 0,0 & 0,0 \\
\hline & & $11-20$ & 21,89 & 0,00 & $-7,2$ & 0,0 \\
\hline & & $21-31$ & 21,27 & 20,80 & $-2,4$ & 0,0 \\
\hline \multirow{3}{*}{2002} & \multirow{3}{*}{ Setembro } & $1-10$ & 18,73 & 12,10 & $-2,5$ & 0,0 \\
\hline & & $11-20$ & 23,16 & 31,00 & 0,0 & 0,0 \\
\hline & & $21-30$ & 19,85 & 2,50 & $-11,2$ & 0,0 \\
\hline \multirow{3}{*}{2002} & \multirow{3}{*}{ Outubro } & $1-10$ & 25,92 & 2,00 & $-32,7$ & 0,0 \\
\hline & & $11-20$ & 27,40 & 2,20 & $-45,3$ & 0,0 \\
\hline & & $21-31$ & 25,62 & 45,20 & $-2,9$ & 0,0 \\
\hline \multirow{3}{*}{2002} & \multirow{3}{*}{ Novembro } & $1-10$ & 23,23 & 7,50 & $-25,5$ & 0,0 \\
\hline & & $11-20$ & 24,99 & 69,50 & 0,0 & 0,0 \\
\hline & & $21-30$ & 25,90 & 99,40 & 0,0 & 31,2 \\
\hline \multirow{3}{*}{2002} & \multirow{3}{*}{ Dezembro } & $1-10$ & 25,67 & 62,30 & 0,0 & 16,1 \\
\hline & & $11-20$ & 25,06 & 91,20 & 0,0 & 47,8 \\
\hline & & $21-31$ & 25,50 & 11,20 & $-12,0$ & 0,0 \\
\hline
\end{tabular}




\section{APÊNDICE 3}

Massa média de forragem nos pastos de capim-Marandu ao longo do período experimental

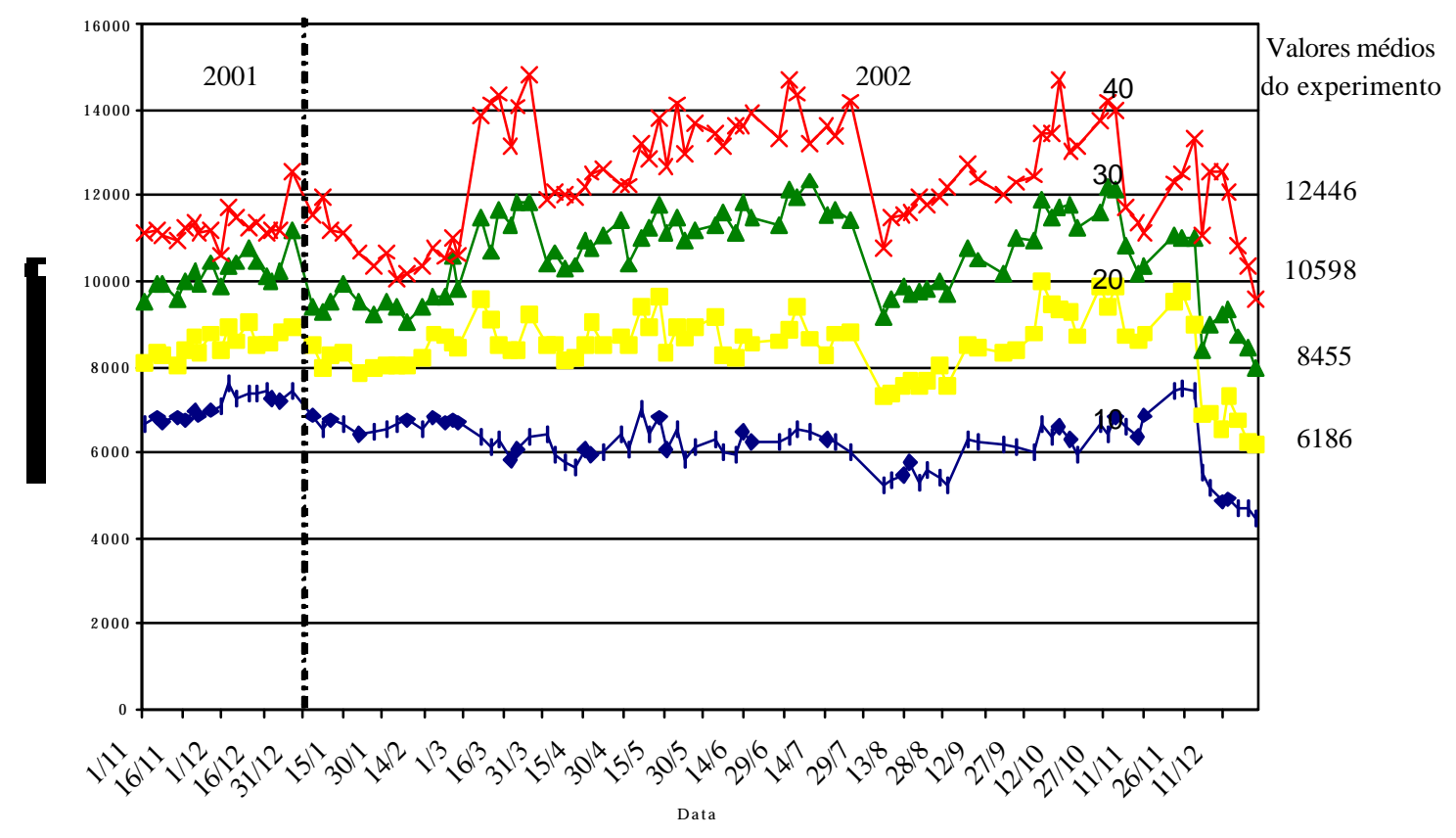

